UNIVERSIDADE DE SÃO PAULO

FACULDADE DE FILOSOFIA, LETRAS E CIÊNCIAS HUMANAS DEPARTAMENTO DE LETRAS CLÁSSICAS E VERNÁCULAS

PROGRAMA DE PÓS-GRADUAÇÃO EM FILOLOGIA E LÍNGUA PORTUGUESA

Letícia Fernandes de Britto-Costa

\title{
A construção da identidade em periódicos infantis no Brasil de Vargas e na Alemanha nazista
}

Esse exemplar consiste em uma versão corrigida. 
UNIVERSIDADE DE SÃO PAULO

FACULDADE DE FILOSOFIA, LETRAS E CIÊNCIAS HUMANAS

DEPARTAMENTO DE LETRAS CLÁSSICAS E VERNÁCULAS

PROGRAMA DE PÓS-GRADUAÇÃO EM FILOLOGIA E LÍNGUA

PORTUGUESA

\section{A construção da identidade em periódicos infantis no Brasil de Vargas e na Alemanha nazista}

Dissertação apresentada ao Programa de Pósgraduação em Filologia Língua Portuguesa do Departamento de Letras Clássicas e Vernáculas da Faculdade de Filosofia, Letras e Ciências Humanas da Universidade de São Paulo, para obtenção do título de Mestra em Letras, sob orientação da Profa. Dra. Zilda Gaspar Oliveira de Aquino.

Esse exemplar consiste em uma versão corrigida. 
Autorizo a reprodução e divulgação total ou parcial deste trabalho, por qualquer meio convencional ou eletrônico, para fins de estudo e pesquisa, desde que citada a fonte.

Catalogação na Publicação

Serviço de Biblioteca e Documentação

Faculdade de Filosofia, Letras e Ciências Humanas da Universidade de São Paulo

B8 $62 \mathrm{C}$

Britto-Costa, Letícia Fernandes de

A construção da identidade em periódicos infantis no Brasil de Vargas e na Alemanha nazista / Letícia Fernandes de Britto-Costa ; orientadora Zilda Gaspar Oliveira de Aquino. - São Paulo, 2017.

$180 \mathrm{f}$.

Dissertação (Mestrado) - Faculdade de Filosofia, Letras e Ciências Humanas da Universidade de São Paulo. Departamento de Letras Clássicas e

Vernáculas. Área de concentração: Filologia e Língua Portuguesa.

1. Discurso Infantil. 2. Identidade no Discurso. 3. Argumentação. 4. Língua Portuguesa. 5. Língua Alemã. I. Aquino, Zilda Gaspar Oliveira de, orient. II. Título. 


\section{Folha de Aprovação}

BRITTO-COSTA, Letícia Fernandes de

\section{A construção da identidade em periódicos infantis no Brasil de Vargas e na Alemanha nazista}

Dissertação apresentada ao Programa de Pós-graduação em Filologia Língua Portuguesa do Departamento de Letras Clássicas e Vernáculas da Faculdade de Filosofia, Letras e Ciências Humanas da Universidade de São Paulo, para obtenção do título de Mestra em Letras.

Área de concentração: Linguística Textual e Análise do Discurso

Aprovada em: 16/12/2016

BANCA EXAMINADORA

Profa. Dra. Zilda Gaspar Oliveira de Aquino (FFLCH - USP)

Orientadora e Presidente da banca

Prof $^{a}$ Dra. Maria Eduarda Giering (UVRS)

Prof $^{a}$ Dra. Rosana Soares (ECA-USP)

Prof. Dr. José da Silva Simões (FFLCH-USP) 
Ao Henrique e à Mariana, que foram crianças comigo. 


\section{Agradecimentos}

À banca de professores, por dedicarem ao meu trabalho seu tempo e cuidado. Especialmente aos professores Rosana Soares e José Simões, pelas contribuições em meu exame de qualificação. À minha orientadora, Professora Zilda Aquino, minha mãe da Ciência que tive o prazer de conhecer em minha primeira aula da graduação e que desde então me orienta acadêmica e espiritualmente. Ainda me lembro de suas primeiras palavras que abriram o curso de Introdução aos Estudos de Língua Portuguesa I: "Quem nós somos, ou quem nós queremos ser, marca-se em nosso discurso". Uma frase simples, que venho procurando entender melhor nos últimos oito anos.

Aos meus pais, Luciano e Kika, pelo apoio incondicional desde a primeira palavra lida, sem o qual não teria chegado aqui. Muito obrigada por não apenas aceitarem, mas também se orgulharem do caminho que escolhi trilhar. Aos meus irmãos, Henrique e Mariana, a quem dedico este trabalho, por terem compartilhado sua infância comigo, e por me fazerem voltar a ela sempre que nos reencontramos. Ao André, meu companheiro que escolhi para partilhar as alegrias e tropeços do cotidiano e da Ciência. Muito obrigada por sempre me apoiar, acalmar e incentivar, nos dias mais difíceis desse trajeto e principalmente por dividir comigo os malabarismos diários para dar conta de tudo.

Ao meu avô Luciano e aos meus tios Henrique e Terezinha, por me acolherem tão bem nessa Paulicéia Desvairada e por me oferecerem sempre o mesmo suporte emocional que tive na casa dos meus pais. Vocês conseguiram fazer de São Paulo meu segundo lar. Aos Paetzods, minha família alemã, por terem me recebido com tanto entusiasmo e carinho durante meu intercâmbio. Ao lado de vocês aprendi muito mais que um idioma: conheci uma nova cultura e um novo lugar a pertencer. Ich hab' euch Lieb.

Aos meus amigos da graduação - a famigerada Turma do Pedro e as "Bonitas do Alemón" - e do grupo de estudos da pós - meus irmãos de orientação, pelos momentos mais felizes do início da minha vida adulta, e por compartilharem comigo todos os dias desse difícil e maravilhoso desafio. Aos amigos que a vida me presenteou: Marcela, Isabela, Diego, Edu, Júlio, Kata, Carol e Elaine, por me apoiarem e acompanharem em todo esse trajeto. À Sellene pelas imprescindíveis revisões em língua inglesa. À Andressa, por todas as (não)semelhanças que compartilhamos na vida e na pesquisa. 


\section{Resumo}

BRITTO-COSTA, Letícia Fernandes de. A construção da identidade em periódicos infantis no Brasil de Vargas e na Alemanha nazista. 180f. Dissertação (Mestrado) Faculdade de Filosofia, Letras e Ciências Humanas, Universidade de São Paulo, São Paulo, 2017.

A presente dissertação tem por proposta investigar a construção da identidade infantil a partir do discurso de adultos e crianças que se apresenta na mídia impressa em revistas voltadas para o público infantil, publicadas na década de 1930, no Brasil e na Alemanha. Busca-se observar como se caracteriza esse discurso e quais argumentos foram imprescindíveis para a construção de tal identidade em dois regimes nacionalistas concomitantes - o início da Era Vargas, no Brasil, e do Nazismo, na Alemanha. Os corpora constituem-se da revista "O Tico-Tico", publicada no Rio de Janeiro; e dos textos do jornal Hilf mit!" Illustrierte deutsche Schülerzeitung", publicado em Berlim. Esses periódicos eram distribuídos nas maiores metrópoles de seus respectivos países e, por isso, se apresentam como bastante significativos quanto à representação da imagem da criança nessas grandes cidades e em culturas distintas. Visando observar tal questão, selecionamos como embasamento teórico os estudos de Wolf (1999) e Lopes (2005) no que se refere às pesquisas em Comunicação; os preceitos de Perelman e Olbrechts-Tyteca (1996 [1958]) e Klein (1980) a respeito de valores argumentativos e validades coletivas; a definição de Ideologia proposta por van Dijk (2000); os conceitos de Discurso Autoritário e Discurso Interiormente Persuasivo, proposto por Bakhtin (2015 [1930]); bem como pesquisas da área de Identidade no Discurso, como de Jungwirth (2007), Moita Lopes (2002) e seus seguidores. Após traçarmos o contexto histórico, político e comunicacional que circundam os periódicos, os textos foram analisados, com luz às teorias da Argumentação, buscando-se observar as estratégias discursivas e, sobretudo, os valores argumentativos e as validades coletivas difundidos nos discursos a partir da seleção lexical; os resultados obtidos na pesquisa nos permitiram observar questões voltadas às ideologias e às identidades construídas nesses textos. As análises apontaram para uma maior autonomia discursiva, ideológica e identitária nos textos de autoria atribuída às crianças na revista brasileira em relação à revista alemã, apesar de tal autonomia não se apresentar como algo absoluto em relação a alguns valores sociais.

Palavras-chave: Discurso Infantil; Identidade no Discurso; Argumentação; Língua Portuguesa; Língua Alemã. 


\begin{abstract}
BRITTO-COSTA, Letícia Fernandes de. The construction of identity in children's magazines in Varga's Brazil and Nazi German. 180f. Master's dissertation Faculdade de Filosofia, Letras e Ciências Humanas, Universidade de São Paulo, São Paulo, 2017.

This master's dissertation aims to investigate the construction of the juvenile identity through the discourse of adults and children presented in printed media, specifically in magazines whose target audience is children. The magazines analyzed were published in the 1930s in Brazil and Germany. The intention is to observe how the aforementioned discourse is characterized and which arguments are essential for the construction of such an identity during two distinct political periods, Vargas' Brazil and Nazi Germany. The corpora consist of the magazine "O Tico-Tico", published in Rio de Janeiro; and of texts from the newspaper "Hilf mit! Illustrierte deutsche Schülerzeitung", published in Berlin. Those magazines were distributed in the main metropolises of their countries of origin and therefore may be significant in the representation of the image of children in those large cities and distinct cultures. Therefore, the chosen theoretical foundation includes: the communication studies of Wolf (1999) and Lopes (2005); the precepts of Perelman and Olbrechts-Tyteca (1996 [1958]) and Klein's (1980) argumentative values and collective validity; Van Dijk's (2000) definition of ideology; the concept of authoritarian speech by Bakhtin (2015 [1930]); as well as works by specialists in identity in discourse such as Jungwirth (2007), Moita Lopes (2002) and others that study their works. After investigating the historical, political and communicational context that surrounds those magazines, the texts were analyzed using the theory of argumentation, to observe the discourse strategies and especially the argumentative values diffused in the discourses through the lexical selection. The results obtained in this research allow us to observe issues related to the ideologies and identities that were constructed in those texts. The analyses point to greater autonomy in terms of discourse, ideology and identity in Brazilian texts, whose authorship was attributed to children, in comparison with the German texts, although such autonomy is not absolute regarding some social values.
\end{abstract}

Key-Words: Children's Identity; Discourse and Identity; Argumentation; Portuguese Language; German Language. 


\begin{abstract}
BRITTO-COSTA, Letícia Fernandes de. Die Bildung der Identität in Kinderzeitungen aus Vargas Brasilien und nazi Deutschland. 180f. Masterthesis Faculdade de Filosofia, Letras e Ciências Humanas, Universidade de São Paulo, São Paulo, 2017.

Dieses Thesis hat als Absicht die Konstruktion der KinderidentitÄt mittels der Diskurse aus Kinderzeitschriften zu forschen, die am 1930 in Brasilien und in Detuschland veröffentlich wurden. Es wird untersucht, wie solche Diskurse sich charakterisiert werden und was für Argument unbedingt wurden, um diese Identität auszubilden, in zwei nationalistische Regime, die aus dem 1930 Jahrzehnt errichtet: "O Tico-Tico", aus Rio de Janeiro, und "Hilf mit! Illustrierte deutsche Schülerzeitung", aus Berlin. Diese Zeitschriften wurden in den größten Stäten der beiden Ländern ausgegeben, und deswegen können besondere Informationen über die Bildung der Kinderidentität enthalten. In diesem Sinn wurde als theoretische Grundlage die folgenden Theorien ausgewählt: die Studien von Wolf (1999) und Lopes (2005) über die Forschungen in Berich von Kommunikationsforschungen; die Vorschriften von Perelman und Olbrechts-Tyteca (1996 [1958]), und Klein (1980) hinsichtlich der argumentativen Werte und der kollektiven Geltungen; die Definitionenvon von van Dijk (2000) über die), Moita Lopes (2002) und ihre Anhänger. Nach einer Untersuchung Untersuchung über den historischen, politischen, und kommunikativen Kontext der Texte, wurden die Diskurse analysiert, mithilfe der argumentativen Theorien, um die diskursive Strategien $\mathrm{zu}$ beobachten, besonders in Bezug auf die argumentativen Werte und die kollektiven Geltungen, durch die Auswertung der lexikalischen Auswahl; die Ergebnisse, die in dieser Forschung erhalten wurden, hat uns ermöglicht, Gegenstände zu beobachten, die zur Ideologie und Identität in solchen Texten zeigen. Die Analysen deuten in den brasilianischen Kindertexten auf eine eine größere Autonomie, in Hinsicht auf Diskursprodutkion, Ideologie und Identität in Vergleichung zu den deutschen, obwohl diese Autonomie nicht ganz unbedingt sich bildet, in Bezug auf manche argumentative Werte.
\end{abstract}

Schlusswörter:Kinderdiscurkurse;

Diskursidentität;

Argumentation; Portugiesichsprache; Deutschsprache. 


\section{SUMÁRIO}

Introdução. XV

Metodologia XXI

Caracterização dos Corpora XXIII

Organização do Trabalho XXVII

Capítulo I - Contexto, Interação e .30

Discurso. .30

1.1 Estudos de Contexto e Discurso 30

1.2 Brasil e Alemanha na década de 1930 - perspectivas da educação infantil

1.2.1 Vargas, positivismo e eugenia social na infância.

1.2.2 Nazismo, eugenia racial e a Juventude Hitlerista.

1.2.3 Aproximações e afastamentos políticos entre Brasil e Alemanha por volta de 1930 39

1.3 O Papel da Mídia no Brasil e na Alemanha na década de 1930 40

1.3.1 Aspectos comunicacionais na revista brasileira "O Tico-Tico" 43

1.3.2 Aspectos comunicacionais no jornal alemão "Hilf mit!" 48

1.3.3 Correlação entre os dois periódicos do ponto de vista midiático 51

Capítulo II - Argumentação: Mecanismos Lógicos e Sociointeracionais .53

2.1 Percurso Histórico dos Estudos de Argumentação 53

2.2 Competência e Produção Argumentativa na Infância. 56

2.3 Sociointeracionismo e Lógica na Argumentação 57

2.3.1 Estrutura e encaminhamento argumentativo em "Hilf mit!" 58 
2.3.2 Estrutura e encaminhamento argumentativo em O Tico-Tico Mundano.... 80

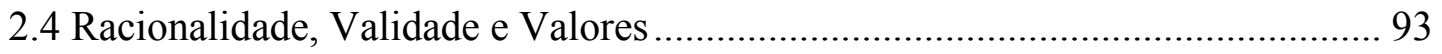

2.5 Aproximações e afastamentos entre os corpora em termos de argumentação... 101

Capítulo III - Ideologia e Identidade 104

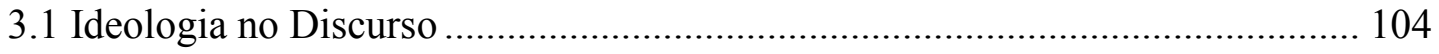

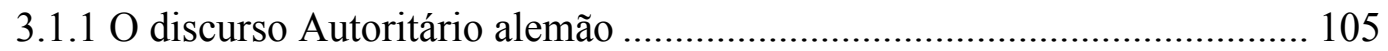

3.1.2 O Discurso Interiormente Persuasivo no Brasil ........................................ 110

3.1.3 Correlação entre os periódicos ................................................................ 113

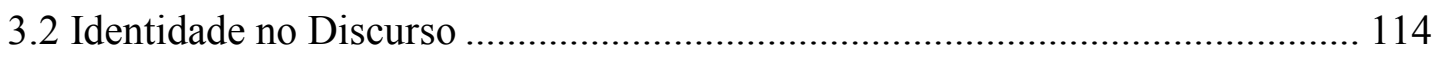

3.2.1 A construção da identidade da criança em "Hilf mit!"............................ 119

3.2.2 A construção da identidade da criança em O Tico-Tico .......................... 124

3.2.3 Correlação entre os processos de construção de identidade nos periódicos

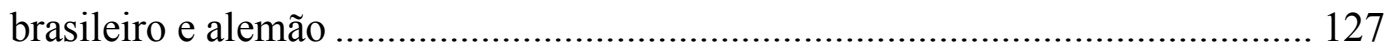

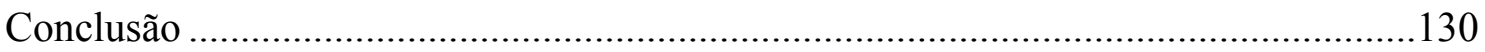

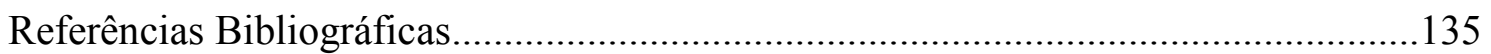

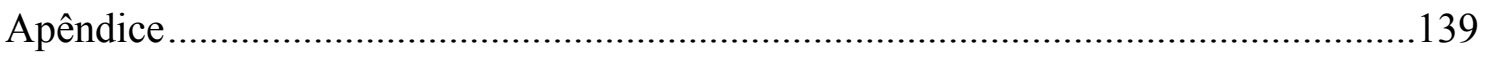

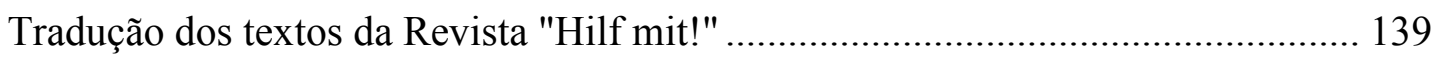

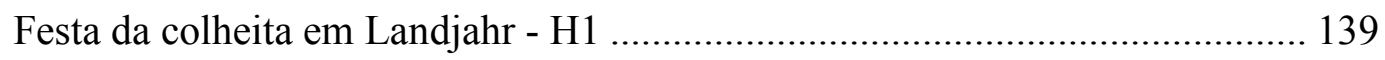

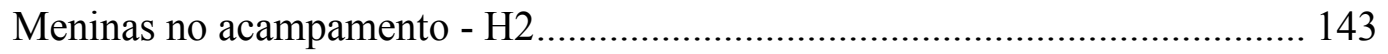

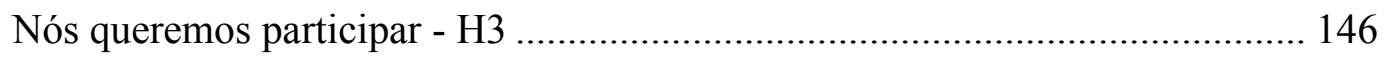

Cedros de Natal em Usambara - H4 .............................................................. 150

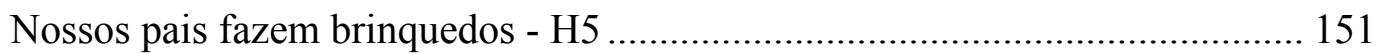


Transcrição dos Textos de "O Tico-Tico Mundano".

O Tico-Tico Mundano - T1

O Tico-Tico Mundano - T2 156

O Tico-Tico Mundano - T3 159

O Tico-Tico Mundano - T4 162

O Tico-Tico Mundano - T 5 165

O Tico-Tico Mundano - T6. 168

O Tico-Tico Mundano - T7 170

O Tico-Tico Mundano - T8 173

O Tico-Tico Mundano - T9 176

O Tico-Tico Mundano - T10 179

\section{ÍNDICE DE FIGURAS}

Quadro 1- Lista de artigos da revista "O Tico-Tico" XXV

Figura 1: "O Tico-Tico". Ed 1508, agosto de 1934, pg. 29. .45

Figura 2:Propaganda do sabonete "Eucalol". "O Tico-Tico", Ed. 1535, março de 1935, pg. 2 . .46

Figura 3: Propaganda de livro da editora "O Malho". O Tico-Tico", Ed. 1535, março de 1935, pg. 2.

Figura 4: "Geografisches Rätsel" - Em português, "Enigma geográfico", composto por um quebra-cabeças do mapa da Alemanha de 1935, pg. 28 .49 
Figura 5: H1, Erntfest im Landjahr. Outubro 1935, pág. 6 .60

Figura 6: H1, Erntfest im Landjahr. Outubro 1935, pág. 7. .61

Figura 7: H2, Mädel im Lader, outubro de 1935, pg.14. 64

Figura 8: H2, Mädel am Lager outubro de 1935, pg.15 65

Figura 9: H3, Wir wollen mithelfen, outubro de 1935, pg.30..... .69

Figura 10: H3, Wir wollen mithelfen, outubro de 1935, pg.31 .70

Figura 11: H4, Weihnachtszedern im Usambara, dezembro de 1935, pg.78. .74

Figura 12: H4, Weihnachtszedern im Usambara, dezembro de 1935, pg.79 .75

Figura 13: H5, Unsere Väter machen Spielzeug, dezembro de 1935, pg.80....... . .77

Figura 14: H5, Unsere Väter machen Spielzeug, dezembro de 1935, pg.81 . .78

Figura 15: T1, O Tico-Tico Mundano, Ed. 1475, janeiro de1934, pg. 25. .81

Figura 16: T2, O Tico-Tico Mundano, Ed. 1480, fevereiro de1934, pg.6. .82

Figura 17: T3, O Tico-Tico Mundano, Ed. 1484, março de 1934, pg. 6 .83

Figura 18: T4, Ed. 1487, abril de 1934, p. 4 .84

Figura 19: T5, Ed. 1492, maio de1934, pg. 4 .85

Figura 20: T6, O Tico-Tico Mundano, Ed. 1496, junho de 1934, pg. 6 .86

Figura 21: T7, O Tico-Tico Mundano, Ed. 1500, julho de 1934, pg. 6 .87

Figura 22: T8, O Tico-Tico Mundano, Ed. 1504, agosto de 1934, pg. 6 .88

Figura 23: T9, O Tico-Tico Mundano, Ed. 1524, dezembro de 1934, pg. 6 .89

Figura 24: T10, O Tico-Tico Mundano, Ed. 1535, fevereiro de 1935, pg. 6 .90

Figura 25: Capa da primeira edição do jornal escolar "Hilf mit!", 1933 120 
Figura 26: Imagem da viagem das jovens tropas alemãs pelo território nacional. Hilf mit!, dezembro de 1935.

Figura 27: Capa com história ilustrada de Esopo, "O Tico-Tico" edição 1479, fevereiro de 1934. 126

Figura 28:História ilustrada Na Escola, "O Tico-Tico" ed. 1407, abril de 1934. 126

Índice de Quadros

Quadro 1- Lista de artigos da revista "O Tico-Tico XXV

Quadro 2- Lista de artigos do jornal "Hilf mit!" XXVI

Quadro 4 - Elementos nominais atribuídos aos meninos . .98

Quadro 2- Elementos nominais atribuídos aos meninos . .99

Quadro 5 - Elementos nominais atribuídos às crianças em "Hilf mit!" 100

Quadro 6 - Tradução dos elementos nominais atribuídos às crianças em "Hilf mit!"...100 
Linguagem: a pele. Victor Afonso Soto, 7 anos, In: "Casa das estrelas: o universo contado pelas crianças" 


\section{INTRODUÇÃo}

Periódicos voltados ao público infantil vêm demarcando cada vez mais espaço de circulação nas últimas décadas. Desde o início do século $\mathrm{XX}$, muito foi produzido no contexto midiático, porém, em termos acadêmicos, pouco se voltou a esses veículos de massa, sobretudo no que se refere aos estudos discursivos e de comunicação, como observa Buckingham (2012). Conforme o autor, esses materiais contêm conteúdos ideológicos e repertórios culturais próprios dos períodos em que foram produzidos, assim como qualquer outro discurso, merecendo, portanto, a atenção dos pesquisadores da área. Ele afirma: "Classe social, gênero e raça foram preocupações centrais, mas a idade, enquanto dimensão igualmente significativa de poder social, foi estranhamente negligenciada." (BUCKINGHAM, 2012:95).

O autor também observa que as poucas pesquisas realizadas nos estudos de Comunicação baseadas na perspectiva etária eram, em sua maioria, relacionadas à Psicologia, e versava sobre os efeitos da mídia nas crianças, o que, para Buckingham (2012), leva ao tratamento desse público como um mero receptor passivo, pois desconsidera a criança enquanto sujeito interacional, isto é, como também produtor de sentido de textos a ela direcionados. Por outro lado, as interações do ser humano, seja ele adulto ou criança, sempre visa a causar efeitos persuasivos em seu interlocutor. Tal concepção nos motivou a investigar os recursos linguístico-discursivos que podem revelar características importantes no que se refere às representações sociais e relações de poder que estão marcadas nos textos produzidos por e para crianças.

Ao buscarmos um periódico no Brasil, deparamo-nos com a dificuldade de localização de revistas infantis digitalizadas. No site da Biblioteca Nacional ${ }^{1}$, encontramos "O Tico-Tico" e, dado seu período de publicação - entre os anos de 1905 a 1977 - e sua vasta disponibilidade para estudos, recortamos o período de 1934 a 1935, por se tratar do início do primeiro governo de Vargas, fortemente marcado por ideais nacionalistas. Essa busca, suscitou nossa motivação a pesquisar como se teria produzido um periódico em um dos governos nacionalistas mais marcantes no mundo - o regime nazista - e, nosso contato com língua alemã, levou-nos a localizar o 
"Hilf mit! Illustrierte deutsche Schülerzeitung" ${ }^{2}$ que circulou em época concomitante àquele.

O fato de essas duas sociedades viverem momentos políticos de cunho nacionalista, porém bastante distintos, numa mesma época - o início da Era Vargas, no Brasil, e o apogeu do Nazismo, na Alemanha - levou-nos aos seguintes questionamentos: seria possível observar, nos textos de autoria atribuída às crianças, como se dava a construção da identidade infantil nesses discursos? E se isso for possível, qual o grau de influência exercida pelo contexto sociopolítico em tais representações de papéis sociais? Esta pesquisa surgiu, então, da necessidade de se investigar essas duas questões, que ainda não receberam a devida atenção dos estudiosos da área, conforme conseguimos alcançar.

Com isso, temos por objetivo estudar o discurso da mídia voltado ao público infantil, para conhecer o processo de construção de identidades a partir de contextos sociopolíticos específicos no Brasil e na Alemanha. De modo mais específico, propomo-nos a compreender, a partir das formulações linguísticodiscursivas, a maneira com que a identidade infantil é construída em discursos de autoria atribuída às crianças nesses veículos midiáticos; para tanto, entendemos ser necessário observar aspectos sociopolíticos específicos, como o início da Era Vargas e o totalitarismo nazista na Alemanha, para conhecer a influência destes no comportamento linguístico infantil, especialmente quanto às estratégias argumentativas que selecionaram e que podem revelar sua construção identitária.

Pensando numa metodologia de estudo da identidade voltada para os estudos discursivos - uma vez que não podemos prescindir do tratamento de aspectos linguísticos que tragam à luz as conjunturas sócio-históricas e até ideológicas que permeiam um dado texto - encontramos em Adão (2006) a ideia de que, devido ao fato de constituir um objeto de estudo de extrema heterogeneidade, pois engloba diversos níveis e dimensões linguísticos, a língua não permite a existência de uma única perspectiva teórica e metodológica. Sendo assim, é de extrema importância termos em vista que tal área tem por objeto um fenômeno interdisciplinar e heterogêneo.

A própria Análise do Discurso é caracterizada pela divergência teórica, uma vez que congrega diferentes propostas; isso significa dizer que estamos tomando uma concepção de $\mathrm{AD}$ em seu sentido lato e não da $\mathrm{AD}$ francesa. "É nesse sentido que não

\footnotetext{
${ }^{2}$ Em português: "Colabore! Jornal escolar ilustrado alemão", disponível no site https://archive.org.
} 
se pode, segundo Maingueneau (1993), falar em uma única análise do discurso, mas em análises de discursos, pois há uma diversidade de trabalhos realizados em conexão com a história, com a sociolinguística, com a etnolinguística, com a análise da conversação, entre outras disciplinas.” (ADÃO, 2006:35). Essa posição é hoje referendada por Fiorin (2013) que indica estar a AD francesa em meio a muitas ADs.

Assim, pode-se dizer que as várias propostas teórico-metodológicas da $\mathrm{AD}$ contribuem para uma heterogeneidade conceitual que acaba por favorecer a interdisciplinaridade em tais estudos. Tão importante quanto debater quais linhas de pesquisa são as mais adequadas é compreender as contribuições que cada uma delas traz para os diversos campos científicos. Com isso, entendemos ser possível vincular à $\mathrm{AD}$ diversas áreas de estudos linguísticos, como a cognição, argumentação, entre outros.

Nesse sentido, buscamos uma abordagem dos estudos linguísticos que procure abranger as questões do entorno social presentes nos discursos, visto que concebemosa língua indissociável do contexto e ideologias em que circula. Por conta disso, selecionamos o aparato teórico de Van Dijk (2012) no que se refere à caracterização do conceito de contexto por ele defendido, localizando-o como um resultado das interações entre os sujeitos enunciadores, ou seja, como um produto de processos cognitivos e sociais que permeiam os discursos. Essas duas propostas teóricas e metodológicas nos forneceram também embasamento para a busca por estudos da área da historiografia voltados especificamente para os contextos sociopolíticos em que ambos os corpora circulavam.

E justamente por tratarmos não apenas de momentos históricos bastante específicos, mas sobretudo de textos veiculados por meios de comunicação em massa, compreendemos também ser bastante importante nos debruçarmos sobre estudos específicos da área de Comunicação. A esse respeito localizamos os preceitos de Lopes (2005) que situa a Comunicação como uma área interdisciplinar, uma vez que, assim como a língua, os meios de comunicação são situados num contexto específico e, apesar de se constituir como uma ciência autônoma, o pesquisador que trabalha com tais materiais deve atentar também para as questões políticas, sociais e culturais que envolveram o processo de produção e difusão dos textos midiáticos.

Wolf (1999), outro estudioso das teorias de Comunicação, apresenta-nos a importância de observamos também os emissores dos veículos de informação em massa, o que pode trazer contribuições bastante significativas para estudos que se 
proponham a observar textos midiáticos, pois nos permitem compreender os mecanismos de seleção do que será ou não veiculado ao público, tais como seus patrocinadores e o posicionamento político de seus editores. Com isso, o autor nos apresenta a teoria dos Gatekeepers, fundada por Lewin (1947), que se propõe a estudar justamente a relação entre a escolha das informações noticiadas nos meios de comunicação e os interesses políticos e financeiros de tais veículos.

Desse modo, compreendemos que tais perspectivas teóricas para os estudos linguísticos e de Comunicação, além de se fundarem numa proposta interdisciplinar de pesquisa, apontam sempre também para as questões interacionais presentes nessas duas áreas das Ciências Humanas, visto que, do mesmo modo que os linguistas se preocupam com as relações entre interactantes no momento da enunciação, os pesquisadores de Comunicação atentam para os objetivos que os emissores tentam causar em seus receptores na produção midiática. E em se tratando de objetivos discursivos, voltamonos então para as teorias da Argumentação no Discurso, partindo inicialmente da proposta de Plantin (2008) de que todos os argumentos presentes num dado texto apontam exclusivamente a seu objetivo persuasivo, isto é, ao efeito final que se espera causar em seu enunciatário.

Em uma concepção muito semelhante, Aquino (2015) defende que a Argumentação, enquanto processo interacional, constitui-se como uma negociação de poderes entre seus participantes, em que ambos buscam acordos em termos de adesão à proposta apresentada. Assim, no discurso argumentativo, os interactantes lançam mão de diversos recursos para que seu objetivo persuasivo seja alcançado. Tais recursos se pautam tanto nas relações interpessoais e nas negociações envolvidas nessa interação, quanto na lógica argumentativa, isto é, na racionalidade dos argumentos apresentados.

É nesse sentido que encontramos em Habermas (2012) o conceito de Racional, ou seja, a competência de raciocínio dos indivíduos. Segundo o autor, tal característica se baseia a um só tempo nos processos cognitivos e no contexto social que envolve toda e qualquer interação linguística - algo, aliás, muito semelhante ao que van Dijk (2012) propõe para a caracterização de sua concepção de Contexto. Para Habermas (2012), a racionalidade de um argumento depende, então, tanto da lógica quanto do próprio contexto, visto que é justamente o entorno social que muitas vezes vai definir uma asserção como algo lógico ou racional. Isto significa dizer que, numa sociedade submersa e fundada em conceitos racistas, um argumento também racista será considerado bastante lógico e, por isso, muito bem aceito. 
Klein (1980) também se fundamenta nesse duplo viés da Argumentação - o lógico e o social - e apresenta, nesse sentido, o conceito de validades, definido como argumentos passíveis de serem validados ou considerados racionais em uma dada sociedade. Com isso, o autor defende a existência de validades coletivas, que se constituem de valores já aceitos e compartilhados por um grupo e que são utilizados nos discursos não apenas por seu teor persuasivo, mas também para criar outras validades aceitáveis - ou seja, validades que podem ser aceitas, desde que estejam baseadas em outras já amplamente difundidas pela coletividade.

Numa perspectiva muito semelhante, encontramos em Perelman e OlbrechtsTyteca (1996 [1958]) a noção de valores argumentativos, definida pelos autores como objetos de negociação que, ao mesmo tempo em que possuem um caráter argumentativo - por se tratar de um valor já comungado socialmente - também servem para enraizar ainda mais uma dada ideologia, sempre diretamente vinculada ao mesmo valor. Assim, da mesma forma que um argumento de valor racista é considerado racional numa sociedade que compartilha desses valores, ele também terá como função secundária a manutenção de toda essa ideologia racista nesse grupo social.

Desse modo, compreendemos que o estudo dos valores argumentativos e das validades coletivas podem nos indicar também o grau de influência exercida pela ideologia no momento da enunciação. No que se refere a isso, buscamos em Bakhtin (2015 [1930]) os conceitos de discurso autoritário e discurso interiormente persuasivo, os quais versam a respeito da presença maior ou menor da voz - e é claro, da ideologia - de outrem nos discursos, o que, segundo o autor, está diretamente relacionado ao reconhecimento ou não dessa voz como uma autoridade para o enunciador. Com isso, compreende-se que um discurso de caráter autoritário, tenderá à reprodução de modo mais intenso de ideologias de uma figura de autoridade, enquanto por sua vez, um discurso interiormente persuasivo apresentará uma maior liberdade em termos de adesão à ideologia de que está tratando, justamente por não reconhecer uma figura de autoridade como autora daquele discurso.

Nesse sentido, é possível observarmos que a aceitação ou não de uma ideologia também é marcada pelo reconhecimento ou não do outro, seja ele um interlocutor, ou uma voz anterior, cujo discurso reproduzimos. E é na atenção à alteridade - à palavra do outro - que constituímos a nossa própria identidade, como afirma Grigoletto (2006). A partir dessa concepção, a autora defende que a identidade é uma construção social que parte da negociação entre enunciador e enunciatário e, por isso, atenta para a 
importância de serem observadas as questões interacionais dos discursos e das identidades neles construídas. E por se tratarem de construções sociais, Jungwirth (2006) as define como um efeito de normatizações sociais, daí a importância de se estudá-las também com o apoio de um aparato teórico da área da Sociologia, como propõe a autora alemã.

No que se refere às questões de interação, Moita Lopes (2002) observa que a interação e a negociação no momento da enunciação são os fatores responsáveis pelas três características fundamentais da identidade: a processualidade, justamente por se tratar de uma construção dada na interação entre os participantes; a fragmentabilidade, pois, em decorrência da primeira, cada interação suscitará diferentes construções identitárias; e por fim, a contradição, advinda das duas anteriores e que confere a possibilidade de que uma única pessoa seja representada em diversas imagens e algumas conflitantes entre si, a depender das diferentes situações de interação. Em relação a essas três características fundamentais da identidade, buscamos em Keupp (1999) a concepção de identidade como Patch-Work - um tipo de trabalho artesanal semelhante ao de uma colcha de retalhos-em que os interactantes recolhem os diversos fragmentos identitários e constroem, em conjunto, suas identidades em suas interações.

Tendo em vista a discussão apresentada, compreendemos que, em termos de teorias linguísticas, este trabalho se localiza no limite entre perspectivas sociais e cognitivas, como proposto para o estudo de Contexto, Argumentação e Ideologias. Além disso, esta pesquisa se caracteriza como um estudo interdisciplinar de discursos, que necessita se apoiar em diversas outras áreas da ciência, como a Historiografia - para a reconstrução do momento político em que os corpora se inseriam -, a Sociologia e a Comunicação. Não buscamos com isso alcançar uma pretensa totalidade dos estudos, mas sim recolher outros tipos de fragmentos que também nos permitirão recuperar a identidade infantil no Brasil de Vargas e na Alemanha nazista. 


\section{Metodologia}

A decisão metodológica pautou-se pelas seguintes ações: procedemos à seleção dos corpora de acordo com o critério de que os textos deveriam ser escritos por crianças e datar de 1934 a 1935. A escolha desse período se deve ao fato de priorizarmos, no corpus brasileiro, o início da Assembléia Constituinte - momento político marcado pelo fim da revolução de 1932, pela ordenação jurídica e reforma política no país - e o primeiro ano de sua institucionalização com o Governo Constitucionalista de Vargas; na política alemã, esse período corresponde ao apogeu do Nazismo, em que Adolf Hitler já havia fundido as funções de chanceler e de presidente, passando então a ser chamado de Führer instaurando um regime totalitarista. Entendemos, portanto, que este biênio se configurou como um momento bastante importante no panorama político do Brasil e da Alemanha, marcando, em ambos os países, o início de dois governos nacionalistas e regidos por duas figuras de poder salvo suas especificidades - bastante influentes.

Iniciamos o tratamento dos corpora colocando-nos mais voltados ao contexto sociopolítico em que cada periódico se inseriu - o início da Era Vargas em "O TicoTico" e do Nazismo em "Hilf mit!", tratando, assim, dos discursos enquanto enunciados concretos, isto é, situados em seu contexto sociopolítico e ideológico de produção. Nesse sentido, foram observados os contextos de produção de comunicação em massa de cada um dos periódicos, sob um viés interdisciplinar, como defendido por Lopes (2005). Os processos de formulação discursiva constituíram nosso objeto de análise, observados a partir de categorias que nos encaminhassem para a construção de identidade, à questão ideológica e às estratégias argumentativas utilizadas para esses fins.

Como categoria de análise da estrutura argumentativa, optamos por observar elementos linguístico-discursivos denotadores de negociação e os valores argumentativos, baseando-nos, neste último, na seleção lexical de elementos nominais. Com o auxílio da ferramenta online do site "Tagul - Word Cloud Art" ${ }^{3}$, os elementos recolhidos foram organizados em quadros de palavras, em que quanto maior a frequência de um elemento nominal nos corpora, maior o tamanho tipográfico da mesma palavra na representação nos quadros.

\footnotetext{
${ }^{3}$ Disponível no link https://tagul.com/
} 
No que se refere às ideologias que circulam nos textos, observamos os conceitos de Discurso Autoritário e Discurso Interiormente Persuasivo, proposto por Bakhtin (2015[1930]), em que tomamos a citação do discurso de outrem como principal categoria de análise. Tais questões de ideologia, foram analisadas à luz de aspectos de construção de Identidade. Outra decisão metodológica diz respeito à opção de analisarmos, em "Hilf mit!", os textos a partir de sua língua de origem - o alemão -, tendo em vista que, caso nos pautássemos em qualquer tradução para a análise, estaríamos, na verdade, observando um outro texto, com outros elementos linguísticos não apenas diferentes aos do texto original, mas também distintos em relação aos recursos disponíveis na língua e na cultura do texto de origem. Por outro lado, dado o fato de esta pesquisa ser realizada em língua portuguesa, apresentamos nossa tradução ao longo das exemplificações. 


\section{Caracterização dos Corpora}

A revista "O Tico-Tico", disponível on-line e digitalizada no site da Biblioteca Nacional, foi a primeira revista brasileira voltada ao público infantil. Em suas publicações encontram-se, sobretudo, histórias em quadrinhos e narrativas de cunho moralista. De acordo com Vergueiro (2008:24):

A revista $\mathrm{O}$ Tico-Tico é um marco na indústria editorial brasileira, sendo a mais longeva publicação periódica dirigida à infância no País [...]. Foi também a primeira revista a trazer regularmente histórias em quadrinhos, em uma época em que a linguagem gráfica seqüencial começava a dar seus primeiros passos, enfrentando pressões de todos os tipos, principalmente quanto a seus méritos educacionais.

O periódico foi produzido durante os anos de 1905 a 1977; era publicado apenas às quartas-feiras, até que, a partir de 1911, as publicações passaram a ser reunidas em almanaques no final de cada ano. Visando um recorte do corpus que se enquadre no período a que nos propomos analisar, foram selecionadas dez edições datadas de 1934 e 1935, período correspondente ao início do primeiro governo de Vargas, marcado por uma nova pulsão nacionalista no Brasil. Devido ao nosso enfoque voltado a textos escritos por crianças, são estudados nessa pesquisa apenas discursos atribuídos à autoria infantil, conforme já discutido anteriormente.

Desse modo, foi selecionada a seção $O$ Tico-Tico Mundano ${ }^{4}$ que, inicialmente, propunha-se a noticiar eventos cotidianos da classe dominante da sociedade brasileira, como nascimentos, aniversários de crianças e batizados. O primeiro registro desta seção data de 1918, na $670^{a}$ edição da revista. Após dois anos do seu surgimento, O Tico-Tico Mundano passou a publicar também colunas escritas por seus leitores, crianças e jovens $^{3}$, nas quais se elencam as qualidades e, em raros casos, os defeitos dos amigos e colegas. Em algumas colunas, as características são comparadas a algum elemento específico, como tipos de flores, astros do cinema, elementos da natureza e doces.

\footnotetext{
${ }^{4}$ Apesar de esses textos não terem suas autorias atribuídas claramente às crianças, encontramos na edição n. 1158, de 14 de dezembro de 1927, um grande indício disso. Na seção Correspondência do Dr. Sabe Tudo, destinada ao diálogo entre os editores e seus leitores, aparece, na página 24 a seguinte resposta a uma carta: "CONSTANTE LEITORA (Minas) - $1^{\circ}$ Sim, pode mandar a berlinda [ uma das colunas escrita por crianças] das meninas da cidade onde reside, 'O Tico-Tico Mundano' lhe dará publicidade como é de costume."
} 
A escolha dos textos de $O$ Tico-Tico Mundano ${ }^{5}$ para integrar o corpus brasileiro de análise foi pautada num recorte histórico que abrangesse o primeiro ano do Governo Constitucional de Vargas, isto é o período do início de 1934 ao início de 1935. Nesse sentido, foram coletadas todas as edições desse período disponíveis no site da Biblioteca Nacional e que contassem com essa seção específica. Ressaltamos ainda que analisamos apenas as colunas escritas por crianças nessa seção, e não as seções na íntegra, conforme já mencionado.

O periódico alemão, intitulado "Hilf mit!", foi um veículo de propaganda do Nazismo, publicado durante o regime totalitário da Alemanha e entregue a todos os alunos das escolas do país. As publicações contavam com textos informativos, sugestões de brincadeiras, narrativas, além de cartas enviadas pelos leitores. Segundo Kübler (2002), o jornal, publicado em Berlim, teve cerca de 3,5 milhões de exemplares impressos, sendo sua tiragem reduzida a partir de 1941, por conta da falta de papel.

Com o fim da $2^{\mathrm{a}}$ Guerra Mundial e, consequentemente, a queda do partido Nacional Socialista, em 1945, este e outros periódicos publicados no regime de Hitler foram abolidos, abrindo espaço para a reedição de periódicos infantis extintos em 1933. Por conta disso, foram localizadas apenas quatro edições digitalizadas, disponíveis gratuitamente online, pelo site Archive.org. Sendo assim, propomo-nos aqui a analisar apenas dois números do jornal, datados de 1935, por se tratar do mesmo período selecionado para a revista brasileira.

Por conta dessa política de apagamento de informações a respeito do regime nazista logo após sua queda, o pesquisador que se dedica a estudar produções midiáticas desse período se depara com a dificuldade em encontrar documentos e outros estudos em que possa embasar sua pesquisa. No entanto, é de conhecimento geral os principais mecanismos de atuação de tal governo, principalmente no que se refere à imposição e doutrinação de um intenso sentimento nacionalista para a população. Além disso, outro problema decorrente deste apagamento de informações é a pouca quantidade de textos disponíveis para análise. Desse modo, são analisados apenas cinco seções dentre as duas edições disponíveis - os únicos produzidos por crianças. No

\footnotetext{
${ }^{5}$ Devido à semelhança entre o título da revista e o título da seção no corpus brasileiro, optamos por citar nos dois corpora - o nome dos periódicos entre aspas e o nome das seções em itálico, de modo a explicitar melhor a que estamos nos referindo - se é ao veículo midiático ou ao discurso por ele divulgado.
} 
entanto, estes textos são mais extensos que os de O Tico-Tico Mundano e, por isso, acreditamos que sua escassez não será prejudicial para a execução do presente trabalho.

É necessário lembrarmos que não se pode ter certeza de que os enunciados não tenham sido escritos por crianças, pois tais textos poderiam ter sido facilmente forjados pelos próprios periódicos em que são veiculados. E, ainda que sua autoria seja de fato de crianças, é muito provável que tais enunciados tenham passado por uma revisão e censura antes de serem publicados. Frente a tais discussões e por não ser nosso objetivo discutir questões de autoria, decidimos assumir aqui a autoria informada pelos próprios periódicos.

Ressaltamos também que, a partir das imagens publicadas nesses veículos midiáticos, é possível perceber que o público considerado infantil à época nesses dois países correspondia à idade escolar, dos sete aos dezessete anos. Desse modo, consideraremos aqui "criança” indivíduos dessa faixa etária, embora saibamos que a partir da idade de 13 anos, segundo o psicólogo Steinberg (1993), já tenhamos o período da adolescência.

Dentre as edições disponíveis - isto é, todos os discursos disponíveis on-line e correspondentes ao nosso critério de recorte temporal e autoral -, selecionamos os seguintes textos para análise:

\begin{tabular}{|l|l|l|l|}
\hline $\begin{array}{c}\text { Númerodo } \\
\text { anexo }\end{array}$ & \multicolumn{1}{|c|}{ Edição da Revista } & Páginas & \multicolumn{1}{|c|}{ Título } \\
\hline T1 & Ed. 1475, janeiro de1934 & 25 & O Tico-Tico Mundano \\
\hline T2 & Ed. 1480, fevereiro de 1934 & 6 & O Tico-Tico Mundano \\
\hline T3 & Ed. 1484, março de 1934 & 6 & O Tico-Tico Mundano \\
\hline T4 & Ed. 1487, abril de 1934 & 4 & O Tico-Tico Mundano \\
\hline T5 & Ed. 1492, maio de 1934 & 6 & O Tico-Tico Mundano \\
\hline T6 & Ed. 1496, junho de 1934 & 6 & O Tico-Tico Mundano \\
\hline T7 & Ed. 1500, julho de 1934 & 6 & O Tico-Tico Mundano \\
\hline T8 & Ed. 1504, agosto de 1934 & 6 & O Tico-Tico Mundano \\
\hline T9 & Ed. 1524,dezembro de1934 & 6 & O Tico-Tico Mundano \\
\hline T10 & Ed. 1532, fevereiro de 1935 & 6 & O Tico-Tico Mundano \\
\hline
\end{tabular}

Quadro 1- Lista de artigos da revista "O Tico-Tico" 
XXVI

\begin{tabular}{|l|l|l|l|}
\hline \multicolumn{1}{|c|}{$\begin{array}{c}\text { merodo } \\
\text { anexo }\end{array}$} & Edição da Revista & Páginas & \multicolumn{1}{|c|}{ Título } \\
\hline H1 & Outubro de 1935 & $6-7$ & ErntefestimLandjahr \\
\hline H2 & Outubro de 1935 & $14-15$ & Mädel am Lager \\
\hline H3 & Outubrode 1935 & $30-31$ & Wir wollen mithelfen \\
\hline H4 & Dezembro de 1935 & $78-79$ & Weihnachszedernin Usambara \\
\hline H5 & Dezembro de 1935 & $80-81$ & Unsere Väter machen Spielzeug \\
\hline
\end{tabular}

Quadro 2- Lista de artigos do jornal "Hilf mit!" 


\section{Organização do Trabalho}

Estruturamos o trabalho em três capítulos: o primeiro, "Contexto, Interação e Discurso", tem início com uma discussão teórica a respeito da importância de se pesquisar o contexto sócio-histórico nos estudos discursivos, conforme Voloshínov/Bakhtin (1992[1929]) e Van Dijk (2012). Então, seguimos a uma pesquisa baseada em estudos historiográficos a respeito do momento político vivido no Brasil e na Alemanha na década de 1930, correspondente ao período de publicação dos corpora selecionados. Conforme esses conceitos, lançamos nosso olhar às questões de produção editorial dos dois periódicos.

No segundo capítulo, intitulado "Argumentação: Mecanismos Lógicos e Sociointeracionais", propomo-nos a vincular nossa análise discursiva juntamente com a discussão teórica, de modo a usá-la também como ilustração dos conceitos apresentados. Iniciamos, então, com um percurso dos estudos argumentativos desde a Retórica Clássica, de Aristóteles, passando por sua nova guinada no final da década de 1950, de Perelman e Olbrechts-Tyteca (1996 [1958]) e Toulmin (2001 [1958]), até as pesquisas mais recentes da Argumentação na Língua, sobretudo de Ducrot (1987) e Koch (1993). Em seguida, voltamo-nos a um estudo da competência argumentativa na infância, baseado na proposta de Faria (2004). O capítulo teve continuidade com uma discussão a respeito dos conceitos de validades e valores argumentativos, propostos por Habermas (2012), Klein (1980) e Perelman e Olbrechts-Tyteca (1996 [1958]), que se baseou também numa análise da seleção lexical, cuja importância é ressaltada por Koch (1993).

O terceiro e último capítulo, "Ideologia e Identidade", assim como o anterior, contou com as análises juntamente com as discussões teóricas e nele buscamos relacionar o percurso traçado no primeiro e no segundo capítulos e o que realizamos a partir de então. Desse modo, iniciamos com a discussão do conceito de Ideologia defendido por Van Dijk (2000). Em seguida, damos continuidade com a proposta de Bakhtin (2015 [1930]) a respeito das noções de Discurso Autoritário e Discurso Interiormente Persuasivo. Por fim, voltamo-nos à proposta de Jungwirth (2007) no que se refere às pesquisas de Identidade no Discurso. Passamos, então, a uma análise em termos de construção de identidade por parte das crianças, com base nos resultados já obtidos ao longo de todo o trabalho. Nas 
XXVIII

considerações finais, buscamos uma síntese de toda a teoria selecionada juntamente com uma discussão a respeito dos resultados observados. 



\section{CAPÍtulo I - CONTEXTO, INTERAÇÃO E DISCURSO}

O presente capítulo tem como objetivo situar os corpora em sua condição política e midiática de produção. Para isso, propomos inicialmente uma discussão a respeito da importância da contextualização para os estudos discursivos, baseando-nos nos conceitos de Voloshínov/Bakhtin (1992 [1929]). Em seguida, passamos a um estudo dos momentos sociopolíticos vividos respectivamente no Brasil e na Alemanha na década de 1930, tendo como fundamento os historiadores Fischer (1995) e Decca (1980). Por fim, observamos aspectos de produção midiática dos dois periódicos selecionados a partir dos conceitos apresentados por Lopes (2005) e Wolf (1999), estudiosos da área de Comunicação.

\subsection{Estudos de Contexto e Discurso}

É usual que os estudos sobre discurso se apoiem no contexto para observarem processos de produção. Entre as teorias, encontramos no Círculo Bakhtiniano a proposta de que a língua se realiza em interações social, histórica e politicamente situadas. Pautado também na Filosofia da Linguagem alemã, Voloshínov/Bakhtin (1992 [1929]) propõe a noção de que a língua ocorre na interação entre os sujeitos sociais. De acordo com essa perspectiva, a linguagem não se baseia apenas em um sistema de signos, mas também em seus contextos de produção, proposta muito semelhante ao que vem sendo feita na presente pesquisa. Assim, conforme o autor, para se conhecer uma língua, é necessário ter-se um domínio cultural em relação aos grupos sociais em que esse mesmo idioma é usado. O autor afirma:

Não basta colocar face a face dois homo sapiens quaisquer para que os signos se constituam. É fundamental que esses dois indivíduos estejam socialmente organizados, que formem um grupo (uma unidade social): só assim um sistema de signos pode constituir-se. A consciência individual não só nada pode explicar, mas, ao contrário, deve ela própria ser explicada a partir do meio ideológico e social. (VOLOSHÍNOV/BAKHTIN, 1992 [1929]: 35)

Na concepção de Voloshínov/Bakhtin, é justamente na materialidade da linguagem que a ideologia se manifesta mais claramente, uma vez que "a palavra é o fenômeno ideológico por excelência [...] é o modo mais puro e sensível de relação social" (VOLOSHÍNOV/BAKHTIN, 1992 [1929]:36). Com isso, compreendemos que a unidade 
linguística dá-se justamente na interação verbal, que também corresponde a uma realidade material. Seu enfoque, então, aponta para a necessidade de se debruçar sobre os aspectos contextuais em que os enunciados se inserem, uma vez que um não se desassocia do outro. A essa proposta, o autor chama de Método Social - orientação metodológica se volta para as relações dialógicas da língua, ou seja, para os aspectos extralinguísticos que não podem ser separados do enunciado, tendo em vista constituir-se fenômeno linguístico integral e concreto, situado socialmente tanto por características do período em que foi produzido - aspectos políticos, sociais, entre outros - quanto pelas situações que envolveram essa mesma produção - os enunciatários, os ambientes em que o enunciado circulou, etc.

Numa perspectiva mais recente, encontramos em van Dijk (2012) um estudo aprofundado do conceito de contexto a partir de dez fundamentos principais e interrelacionados $\mathrm{O}$ primeiro deles diz respeito a uma concepção subjetiva do contexto, isto é, de que os contextos não são dados pelos acontecimentos apenas de modo objetivo, mas principalmente construídos pela perspectiva dos interactantes. Em suas palavras, é necessário

[...] realçar que essas situações sociais só conseguem influenciar o discurso através das interpretações (inter)subjetivas que delas fazem os participantes. Essa perspectiva é um caso especial do ponto de vista de que as situações sociais em geral são construtos sociais e de que elas só conseguem influenciar a conduta humana como tais. (VAN DIJK, 2012:34).

O fundamento seguinte, muito relacionado ao anterior, refere-se ao fato de que, assim como eles se constituem de um modo subjetivo, cada contexto também apresenta um caráter único, uma vez que "os conhecimentos (e as opiniões e emoções) dos participantes, a cada momento, precisam ter diferenças, por menores que sejam, para que a própria interação faça sentido para começo de conversa." (VAN DIJK, 2012:34). A noção de contexto enquanto modelo mental também é mencionada como terceiro fundamento de definição do conceito, pois dado seu caráter subjetivo de recepção, compreende-se que o entorno comunicativo é representado por modelos organizadores de produção e compreensão do discurso que nele se inserem, ou seja, o fundamento da subjetividade dos contextos faz que cada interactante o interprete e/ou o produza de acordo com o que sua subjetividade atribui a esse mesmo contexto.

A partir dessa definição, o autor estabelece um novo fundamento, segundo o qual os contextos são tomados como um modelos de experiência, uma vez que a construção dos modelos mentais dos participantes também ocorre por meio de suas experiências vividas em seu cotidiano. Ressalta-se ainda que toda interação é, de certo modo, controlada por tais 
modelos. A esse respeito, van Dijk (2012:35) afirma: "É esse modelo da experiência que não só representa a própria pessoa e o entorno dos seres humanos conscientes, mas também controla as ações que vão realizando, de modo que elas sejam relevantes na situação corrente."

O quinto fundamento, também muito ligado ao anterior, aponta para o caráter esquemático dos modelos de contextos, uma vez que são constituídos por esquemas de categorias de acordo com as normas culturais que os participantes compartilham e com as quais concordam. Isto posto, chegamos ao sexto fundamento, que compreende uma base cognitiva, responsável também pela construção de sentidos e de interpretações dos discursos, a partir da qual os interactantes moldam suas produções discursivas de acordo com o contexto em que se inserem. O sétimo fundamento dos contextos diz respeito à sua base social, pois, apesar de haver uma importante relação com os processos subjetivos dos participantes, tal construção só se faz possível se inserida num sistema de ideologias, normas e valores da comunidade discursiva dos participantes. "Isso significa que os contextos também têm uma importante dimensão intersubjetiva, que é condição primeira para a comunicação e interação." (VAN DIJK, 2012: 36). Desse modo, é possível afirmarmos que os contextos possuem um duplo caráter: social e cognitivo.

Enquanto construções de modelos mentais, os contextos apresentam como oitavo fundamento seu caráter dinâmico, uma vez que são construídos e atualizados ao longo das interações e em paralelo com elas. Por conta disso, é possível que muitas vezes os interactantes possam planejar seus discursos, o que configura o nono fundamento apresentado pelo autor - o caráter planejável dos contextos -, em que os participantes podem prever o contexto de uma dada interação, assim como o fazem com os gêneros discursivos, pois muitos contextos interacionais são aprendidos no cotidiano discursivo. Assim, uma pessoa que vai às compras na feira, por exemplo, já supõe o contexto em que suas interações poderão ocorrer, pois ele já lhe é conhecido.

Tal previsibilidade dos contextos aponta, por fim, para seu décimo e último fundamento, pautado na função pragmática de seus modelos. Essa função, de acordo com o autor "[...] explica como os usuários da língua adaptam sua interação discursiva aos entornos socioculturais e cognitivos do momento [...]. Portanto, uma teoria explícita do contexto também proporciona uma sólida base para várias abordagens em Pragmática." (VAN DIJK, 2012:37-38).

Dadas as principais propriedades do contexto, o autor passa então à diferenciação entre os conceitos de texto e contexto, de acordo com a qual o primeiro é base constitutiva do 
segundo, isto é, por conta de sua caracterização como modelos mentais, o contexto não pode ser reduzido a um texto, mas pode ser deduzido por ele, pois influencia a produção de textos em geral. Outra questão bastante importante abordada pelo autor diz respeito aos diferentes tipos de contextos que podem ser observados em um único discurso, como por exemplo suas esferas, seus modos - escrito, falado, multimodal, entre outros - as relações de seus participantes, suas instituições, seus domínios sociais, seus objetivos e suas interações. Interessa-nos neste trabalho a compreensão de todos esses tipos de contextos, sobretudo as interações, os objetivos - como abordamos adiante, no segundo capítulo - e as instituições sociais em que os corpora se inserem.

Van Dijk (2012:43) aponta, por fim, para a dupla orientação do conceito de contexto na base cognitiva e social, defendendo que estas não são excludentes entre si, mas sim complementares. Ele afirma:

\footnotetext{
Uma definição dos contextos em termos de modelos mentais não implica que precisemos reduzir as influencias mentais, muito pelo contrário. Por meio dessa definição descrevemos e explicamos, antes de mais nada, como certas estruturas sociais locais e globais conseguem influenciar o texto e a fala. $\mathrm{Ou}$ seja, mesmo uma teoria do contexto de bases cognitivas é parte de uma teoria social mais ampla das relações entre sociedade e discurso.
}

Com isso, o autor, que já definira contextos como modelos mentais de base social, propõe uma abordagem sociocognitiva do contexto, o que segundo ele permite uma compreensão mais completa dos mecanismos de funcionamento dos discursos e do uso da língua. Tendo em vista, então, a importância de uma discussão a respeito dos contextos dos discursos, propomos, para a próxima seção, o estudo do momento sociopolítico vivido no Brasil da Era Vargas e na Alemanha nazista - referentes ao contexto de produção e de circulação dos corpora selecionados -, de modo a observar também questões vinculadas à educação informal veiculadas nos periódicos "O Tico-Tico" e "Hilf mit!".

\subsection{Brasil e Alemanha na década de 1930 - perspectivas da educação infantil}

\subsubsection{Vargas, positivismo e eugenia social na infância}

É sabido que um único "fato histórico" pode ser tratado por meio de diferentes abordagens e perspectivas que fixam a memória de determinada ocorrência, permeada pelos valores do próprio historiador. Por muito tempo, o discurso a respeito da revolução de trinta 
voltou-se para esse momento como um divisor de águas na política brasileira, criador de uma nação autônoma que iniciava seus primeiros passos rumo à industrialização. Segundo Decca (1980), criou-se, nessa concepção, uma ideia de Nação-sujeito, isto é, de uma nação homogênea que agia como um único indivíduo. Ele afirma:

A revolução de trinta, portanto, representa a ideia capaz de construir a Nação-sujeito, legitimando ao mesmo tempo o poder político que encarna essa nova consciência. Não há dúvida quanto à necessidade do exercício do poder enfatizar o fato de ter-se verificado uma revolução unitária e homogênea - , pois é a categoria fundamental de seu discurso de legitimação. (DECCA, 1980: 74).

Nesse sentido, o autor compreende que a construção e a fixação da memória em torno da revolução de trinta se deu de tal modo a servir também como um discurso legitimador desse novo modelo de poder político, baseado num sentimento nacionalista e de comunhão entre toda a população. A própria referência a esse fato como uma "revolução" já é apontada por Decca como um indício de sua legitimação, uma vez que esse termo de conotação bastante positiva no discurso político e histórico pressupõe a aplicação de um novo modelo político, trazido por uma ação direta de uma classe da população anteriormente em situação de opressão e, portanto, vitoriosa.

A crítica do autor a essa visão se fundamenta, sobretudo, no protagonismo conferido a uma suposta união nacionalista de todas as classes brasileiras na luta por um único objetivo, apagando-se, assim, a diferença entre vários grupos sociais que participaram desse movimento no Brasil. Como já foi dito, o termo revolução realiza essa operação no nível do discurso do poder, ao ocultar o processo da luta de classes e ao generalizar, para o conjunto social, a própria origem desse poder a partir de um marco válido para todos - a revolução de trinta. (Decca, 1980: 75-56).

Devido a essa crítica à leitura historiográfica da revolução de trinta, propomos para este trabalho observar o período em questão sob um outro viés. A partir disso buscamos em Lauerhass (1986) a noção de que o governo de Vargas não se colocou nem como um movimento revolucionário e nem como uma mudança de personalidades políticas, mas sim como um meio termo entre esses dois extremos. Isso porque, segundo o autor, o Brasil já passava anteriormente por mudanças ideológicas, motivadas interna e externamente.

Vargas teria, então, apenas acelerado o processo de modernização industrial, e o apoio popular recebido deu-se em grande parte à força do sentimento nacionalista presente na sociedade da época. Lauerhass coloca, desse modo, o nacionalismo como um sistema de 
valorização política que, no caso do Brasil, teve como pano de fundo o processo de mudança político-econômica de um país estritamente agrário para um agroindustrial. Fazendo-se valer de um sistema de valores nacionalistas, Getúlio Vargas pôde concluir, de fato, essa transformação.

No entanto, apesar do processo de modernização ao qual as grandes cidades do país foram submetidas, a desigualdade econômica se manteve. Com isso, ainda que a classe média emergisse socialmente, classes com menor poder aquisitivo, continuavam à margem do acesso a essa modernização. Outro grave problema foi a presença cada vez maior de crianças em situação de rua, que cometiam desde pequenos delitos, como furtos, a atos de violência mais graves. Coincidentemente, no mesmo período, com o fim da Primeira Guerra Mundial, a Sociedade das Nações instituiu aos Estados a ela vinculados a Declaração dos Direitos da Criança em 1921 no Brasil, culminou, em 1927, no Código dos Menores - segundo o qual, a responsabilidade da garantia dos direitos às crianças passaria a ser dividida entre o Estado, a Igreja e a sociedade.

Tal proposta aponta para questões muito importantes que aqui merecem destaque: a primeira delas diz respeito à importância conferida à Igreja neste período, indicando uma tendência bastante conservadora por parte do governo e da população social e economicamente dominante; já a segunda questão diz respeito ao terceiro grupo responsável pela educação de crianças em situação de rua, isto é, à sociedade. Segundo esse novo tratado, as mulheres seriam os principais agentes sociais em prol da recuperação de tais crianças, uma vez que as atribuições maternas extrapolariam os limites da família - outra noção bastante conservadora muito frequente nesse período - para atingir também as crianças sem família e sem formação.

De acordo com Correa (2001:84-85),

\begin{abstract}
Boa parte da retórica sobre a ampliação dos deveres da mãe era resultado da influência do discurso higienista a respeito da família, mas não só: assim como as mães são chamadas a observar os desvios de personalidade de seus filhos, numa política de prevenção típica da atuação médica na época, as professores primárias são também conclamadas a observar seus 'alunos problema'.
\end{abstract}

A partir disso, podemos afirmar que todo o discurso político em prol da criança abandonada e também da formação da criança de "boa família" pautava-se numa ideia não apenas uniformizante mas, sobretudo, eugenizadora do comportamento e identidades infantis. Nesse sentido, ressaltamos que, apesar de se atribuírem novas tarefas às mulheres, essas 
atividades se configuravam, segundo a autora, como uma extensão da função materna na profissionalização feminina. Observamos também que os esforços para higienização se pautavam, sobretudo, num modelo elitista de infância, uma vez que as mulheres responsáveis por essa eugenia pertenciam às classes mais abastadas em termos econômicos. A ideia dessa higienização, conforme Correa (2001) era, portanto, de acabar com a classe pobre, como se a condição dessas pessoas estivesse ligada à saúde mental e física, não a uma situação socioeconômica. Sendo assim, nessa perspectiva, a boa instrução das crianças evitaria que estas se transformassem em criminosos na fase adulta, pois seu caráter ainda estava em vias de ser moldado.

Numa linha semelhante, Carvalho (2001), observa o papel disciplinador e higienizador da escola brasileira no período de 1900 a 1940. Com esse intuito, a autora apresenta a metáfora da disciplina enquanto ortopedia, isto é, a instrução dada à criança num modelo semelhante à correção de uma planta que cresce torta, em que uma atadura colocada no início de seu crescimento poderia proporcionar a ela sua "normalização" e seu "endireitamento" na fase adulta. Segundo a autora, as pesquisas em pedagogia nesse período distinguiam as crianças em três categorias, baseadas num conceito normativo de comportamento: as normais, as anormais e as degeneradas. Carvalho (2001:300) afirma a respeito disso:

\footnotetext{
Observar, medir, classificar, prevenir, corrigir. Em todas essas operações, a remissão à norma é uma constante. A pedagogia científica, as práticas que constituíam e as que derivavam dela caracterizavam-se, assim, por essa remissão constante a cânones de normalidade produzidos, pelo avesso, na literatura de sinais de anormalidade ou degenerescência que a ciência contemporânea colecionava em seu afã de justificar as desigualdades sociais e de explicar o progresso e o atraso dos povos pela existência de determinações inscritas na natureza dos homens. E é por referência a essa norma que a pedagogia se fazia, nas práticas aqui analisadas, ortopedia - arte da prevenção ou da correção da deformação.
}

A partir do exposto, observamos que, num intuito de tratar aspectos puramente sociais enquanto biológicos e psicológicos, o sistema de normas da sociedade da época ditava o que era física e psiquicamente normal, extrapolando, assim, o conceito de normatização para uma normalização. Ressaltamos ainda que a proposta da disciplina ortopédica também carrega consigo uma carga bastante positivista da visão de criança que se tinha na época, uma vez que a correção dos ditos desvios comportamentais deveria acontecer desde a infância, pois este, no pensamento então em vigor, era justamente o período de formação do caráter dos indivíduos. Essa busca pela eugenia também ocorria à mesma época na Alemanha, país em que a educação das crianças desempenhou papel fundamental nesse projeto político de higienização. 
No entanto, nesse país, o processo sofreu forte influência de questões raciais, como discutimos no tópico a seguir.

\subsubsection{Nazismo, eugenia racial e a Juventude Hitlerista}

O Nacional Socialismo ${ }^{6}$, também conhecido como Nazismo, foi, por muito tempo, considerado um modelo político totalitário no mesmo molde de governos como o stalinismo. Porém, pesquisadores como Fischer (1995) defendem que a ideologia ${ }^{7}$ nazista possuiu um caráter único em relação a outros regimes totalitários: o racismo. Fischer também defende que o Nacional Socialismo não foi concebido e imposto unicamente por Adolf Hitler, mas também fomentado por uma classe média que, já no imperialismo europeu pré-guerras, mobilizava-se a partir de uma fundamentação nacionalista, o que possibilitou ao nazismo caracterizar-se como um movimento popular e unificado. Desse modo, "um número considerável de alemães simpatizou com a mensagem política ideológica que o Nazismo trouxe" 8 (FISCHER, 1995:29). Nesse sentido, o autor levanta como principal característica do movimento nazista o termo "völkisch" - isto é, o caráter étnico-populista do regime que visava uma união nacionalista e popular segundo um aspecto racial. Fischer também afirma que toda a nação alemã em geral compartilhava de um conjunto de valores, uma cultura e uma etnia ligados a um passado glorioso e um tanto mitológico, o que colaborou fortemente para a construção coletiva de um sentimento de superioridade da "raça alemã" em detrimento de outras etnias, sentimento já cultivado por grande parte da população. ${ }^{9}$

No entanto, além da prévia aceitação ideológica ao conceito nacionalista, o partido nazista produziu uma intensa propaganda política antes e durante seu regime, o que contribuiu ainda mais para o estabelecimento de tais ideologias eugenistas e racistas. A esse respeito, Fischer afirma: "É por meio da propaganda, é claro, que muitos partidos buscam disseminar suas ideologias, mas o dinamismo e valores militares do nazismo resultaram em sua propaganda, servindo muitas vezes como a própria mensagem" ${ }^{10}$ (FISCHER, 1995: 47). Essa

\footnotetext{
${ }^{6}$ Importante ressaltar que os conceitos de Socialismo aplicados pelo partido nazista são muito distintos da proposta marxista.

${ }^{7}$ Adotamos aqui o conceito de ideologia proposto por van Dijk (2003), o que será discutido com maior profundidade no capítulo 3 deste trabalho.

${ }^{8}$ Tradução nossa

${ }^{9}$ Ressaltamos que não se trata de encontrar os verdadeiros culpados pela força conferida a um regime que culminou, posteriormente, no holocausto durante a Segunda Guerra Mundial; trata-se, na verdade, de se compreender os mecanismos sociopolíticos que viabilizaram a adesão de toda uma nação a um projeto de eugenia da raça alemã.

${ }^{10}$ Tradução nossa
} 
propaganda, ainda segundo esse estudioso, baseou-se tanto numa mistificação da origem do povo alemão, bem como em diversas produções editoriais, como é o caso do jornal escolar "Hilf mit!", selecionado para nossas análises.

No que diz respeito à influência do regime nazista no cotidiano das crianças alemãs, é necessário observar também os dois principais grupos juvenis, diretamente ligados ao governo: a Juventude Hitlerista ${ }^{11}$ e a Liga Federativa de Meninas ${ }^{12}$. De acordo com Monteiro (2013), estes grupos foram formados já em 1922, no início do partido Nacional Socialista e tinham como principal objetivo justamente divulgar os ideais do Nazismo por meio de propaganda partidária. Constituídos inicialmente por meros simpatizantes ao movimento, não havia à época vínculo oficial com a figura de Adolf Hitler. - a oficialização veio só depois do reconhecimento da importância do recrutamento de crianças e adolescentes para os frontes de batalha, e sua obrigatoriedade de filiação começou apenas em 1939, ou seja, posterior à publicação dos textos selecionados para nossa análise.

Alguns meses antes da ascensão do Nazismo ao governo alemão, a Juventude Hitlerista, juntamente com a Liga Federal das Meninas Alemãs, realizou uma conferência em Potsdam, com a presença de cerca de sete mil crianças e jovens - porém nem todos associados aos grupos. Com isso, eles passaram a chamar cada vez mais atenção quanto à importância de sua atuação em prol do partido e, em 1933, com a instauração do regime nazista, o governo alterou a grade curricular da escola básica, obrigando a doutrinação à ideologia de eugenia racial na sala de aula e conferindo maior poder de atuação para a Juventude Hitlerista dentro das escolas. A respeito da alteração curricular à qual a educação formal alemã foi submetida nesse período, Monteiro (2013:16) também afirma:

O próprio movimento nazista era caracterizado por ser pouco voltado à educação e intelectualidade. Por estimular muito mais a força física e a crença baseada nos sentimentos, o pensamento racional e crítico foi desvalorizado, e o pouco dele que restou nas escolas e universidades foi controlado e utilizado pelo partido para disseminar a sua ideologia. Portanto, devido a sua desvalorização institucional como um todo, as escolas representavam pouca autoridade em comparação com a Juventude Hitlerista, e diversas vezes tinham que se submeter à autoridade do governo que defendia os membros da JH [Juventude Hitlerista] nos casos de transgressões e baixo rendimento escolar.

\footnotetext{
${ }^{11}$ Hitlerjugend, em alemão - apenas para meninos.

${ }^{12}$ Bunddeutsche Mädel, em alemão - apenas para meninas.
} 
Desse modo, é possível observar que a força adquirida pela Juventude Hitlerista serviu também de apoio à diminuição do poder da escola, dando espaço para um ensino cada vez mais focado no desempenho físico e deixando de lado o desempenho intelectual. Além desse processo, a entrada da propaganda nazista para as escolas permitiu que toda uma geração fosse doutrinada para apoiar o governo do partido Nacional Socialista.

\subsubsection{Aproximações e afastamentos políticos entre Brasil e Alemanha por volta de 1930}

Apesar de a Alemanha e o Brasil viverem regimes políticos bastante distintos à época dos textos analisados - mais especificamente 1934 e 1935 -, visto que um apresentava-se de cunho totalitário e o outro ainda se caracterizava como democrático, é possível observar diversas semelhanças ideológicas e políticas entre as duas nações. Primeiramente, chamamos atenção para o fato de que ambos os países cultivavam um sentimento nacionalista muito forte, e isso não vinha de uma suposta imposição dos governos então vigentes, mas sim de um pensamento do qual grande parte da população comungava.

Além disso, os dois se voltavam, neste momento, para uma espécie de eugenia, porém com objetivos bastante distintos. Enquanto no Brasil a preocupação era mais social e elitista ou seja, no intuito de se homogeneizar o comportamento dos cidadãos segundo o que era considerado ideal ou "normal" pela elite econômica - na Alemanha nazista, os esforços se voltavam para a hegemonia de uma raça considerada miticamente superior às demais. Não se deve, porém, esquecer que muitas vezes a condição econômica no Brasil era ditada por questões também raciais, visto que até hoje a grande maioria da população com menor renda no país é negra ${ }^{13}$. No entanto, o aspecto racial não aparecia tão claramente no discurso de eugenia que circulava nesse período. Desse modo, apesar de haver, de fato, uma influência racista na má distribuição de renda, tratava-se, na visão da sociedade da época, de um problema de ordem social e moral.

Ressaltamos ainda que os ideais da eugenia se voltam para o aspecto biológico dos indivíduos. Sendo assim, a hegemonia de uma raça ou de um comportamento era uma questão

\footnotetext{
${ }^{13}$ De acordo com o IBGE (2013:178) "Historicamente, pretos e pardos apresentam indicadores sociais desfavoráveis quando comparados à população de cor branca, fruto ainda da histórica exclusão social de amplos segmentos de pretos e pardos, inserções diferenciadas no mercado de trabalho, distribuição regional, acessos desiguais a uma série de bens e serviços, entre diversos outros fatores estruturantes da sociedade brasileira nessa perspectiva."
} 
de saúde pública, o que tira de pauta as discussões sociais, políticas e econômicas, fícando apenas um discurso com base na Medicina a respeito do desenvolvimento dos indivíduos. $\mathrm{E}$ em se tratando de desenvolvimento, observamos mais uma característica de aproximação entre as ideologias presentes em ambos os países: a visão positivista da infância, em que se opta por doutrinar um indivíduo no começo de sua vida, por se tratar de uma fase de constituição do caráter desse mesmo sujeito.

Porém, além da diferença entre o regime político vigente nos dois países, os modos de doutrinação das crianças para se alcançar a eugenia que ambas as sociedades buscavam foram bastante distintos. Na Alemanha, houve uma preocupação muito forte em submeter a escola e o ensino oficial ao Estado, de modo que esta lhe servisse também como veículo de difusão ideológica e de apagamento da criticidade intelectual das crianças. Já no Brasil, apesar de ocorrer também essa política educacional, havia uma necessidade de ampliar o repertório cultural das crianças. No que diz respeito à instrução informal oferecida às crianças nos dois países, este constitui um item de extrema importância para nosso trabalho, dado seu caráter muitas vezes doutrinário, por isso, será por nós discutido, mais adiante, junto de aspectos da produção midiática voltada à infância nesse período.

\subsection{O Papel da Mídia no Brasil e na Alemanha na década de 1930}

Lopes (2005), autora da área de Comunicação defende a importância de se discutir o método de trabalho com a mesma ênfase que se discutem suas conceitualizações teóricas, o que, segundo ela, não tem ocorrido nos atuais estudos de Comunicação, área que se constitui, desde seu surgimento, como uma ciência interdisciplinar, uma vez que seu objeto de pesquisa é situado dentro de um contexto específico, gerando a necessidade de também se observar de modo crítico esses aspectos que lhe são constitutivos. Desse modo, compreendemos que, apesar de sua autonomia enquanto ciência, a Comunicação lança seu olhar para outras áreas de pesquisa. A autora afirma:

Partimos do pressuposto de que a Comunicação se constitui historicamente como um campo autônomo de estudos (aliás, o que ocorreu na história de cada ciência); ela não pode ser investigada fora dos marcos do contexto econômico, social, político e cultural que a envolve. (LOPES, 2005:14) 
Isso confere aos estudos de Comunicação um caráter multidimensional, pois seu próprio objeto de estudo é, por si, multifacetado e plural. Ele exige conhecimento de diversas áreas da ciência e, por conta disso, carece de um tratamento que possa dar conta dessas outras questões, ou seja, de uma metodologia interdisciplinar. Porém, a autora chama a atenção para o fato de que esta interdisciplinaridade não deve ser confundida com uma pretensão de se chegar à totalidade do tratamento de um tema ou de seu esgotamento, mas sim de um outro olhar de pesquisa, em que novos modos de compreensão dos fenômenos possam ser alcançados. Nas palavras da autora:

A função da interdisciplinaridade não é passar uma visão integrada de todo o conhecimento social, mas sim desenvolver um processo de pensamento que, a partir de nossos objetivos do conhecimento, como a Comunicação, busque nova síntese disciplinar. (LOPES, 2005:108).

Ressaltamos, porém, que não apenas o objeto de estudo da comunicação é multifacetado, como também suas propostas de abordagem científica apresentam múltiplas vertentes e possibilidades de pesquisas. Nesse sentido, Wolf (1999) apresenta um percurso histórico dos estudos de comunicação em massa até os dias atuais, perpassando por duas fases teóricas principais, cada uma marcada pela presença de múltiplas correntes científicas algumas até contemporâneas entre si.

Da primeira fase, o autor evidencia as seis principais vertentes. A primeira delas, a Teoria Hipodérmica é caracterizada pela premissa de que os indivíduos são totalmente passivos no que diz respeito à recepção das informações dos veículos de massa. Porém, uma outra perspectiva, a Teoria da Persuasão, aponta para o caráter persuasivo da mensagem midiática; esta concepção vai contra o que a anterior afirmava, pois, se a mensagem é persuasiva, ela não pode ser totalmente manipuladora - compreende-se aqui que a adesão ou não ao que é apresentado pela mídia também está bastante atrelada ao receptor, assumindo-se, assim, que os sujeitos não são totalmente passivos ao que os meios de comunicação veiculam.

A terceira vertente, a Teoria Funcionalista, voltava-se bastante para as questões do entorno comunicacional, ou seja, ao contexto social, político, econômico e ideológico que cercava a emissão de informações para as massas. A Teoria Crítica, por sua vez, compreende o processo midiático como um processo industrial, cujas informações são tidas como produtos da comunicação. Por fim, a Teoria Culturológica relaciona-se bastante à concepção anterior na medida em que busca observar a produção da realidade em cada cultura.

$\mathrm{Na}$ segunda fase dos estudos de Comunicação, como é descrito pelo mesmo autor, observa-se uma maior preocupação em relação ao emissor dos veículos de informação das 
massas. Nesse momento, destacaram-se três principais propostas: a Teoria do Agendamento, segundo a qual os meios de comunicação determinam os eventos e as notícias em destaque; a Teoria do Gatekeeper, ou teoria dos guardiões do portão, que aponta para a existência de um profissional responsável por decidir quais informações serão divulgadas de acordo com a ideologia de cada veículo midiático ou com os interesses de seus respectivos patrocinadores; e, por último, a Teoria dos Newsmarking, de acordo com a qual os jornais, rádios e revistas devem não apenas selecionar o que será noticiado, mas sobretudo o modo com que determinados fatos devem ser relatados, bem como organizar um sistema de produção informacional. Dentre as principais linhas de pesquisa descritas, a Teoria do Gatekeeper apresenta noções bastante importantes para os estudos dos periódicos "Hilf mit!" e "O TicoTico", uma vez que nos auxilia a observar de modo crítico possíveis pistas da seleção e edição dos textos de autoria atribuída às crianças.

O conceito de Gatekeeper foi desenvolvido por Lewin (1947: 145), que o define como aquele que possui "o poder de decidir se deixa passar a informação ou se a bloqueia". Tal noção fundou-se numa pesquisa a respeito de hábitos alimentares, em que o autor constatou a existência de uma zona de filtro em sequências de comportamento em determinados temas, o que pode ser então abstraído para outros estudos. Ele afirma:

O conjunto das forças, antes e depois da zona filtro, é decididamente diferente de tal forma que a passagem, ou o bloqueio, da unidade através de todo o canal, depende, em grande medida, do que acontece na zona filtro. Isso sucede não só com os canais de alimentação, mas também com a sequência de uma informação, dada através dos canais comunicativos, num grupo. (LEWIN, 1947:145).

Partindo dessa concepção, estudiosos da área da comunicação passaram a observar a presença dessa zona de filtro na seleção de informações publicadas pelos veículos de massa. Tais pesquisas apontaram para o fato de que a escolha está muito mais pautada em questões próprias da produção midiática, do que na preocupação com o público alvo. Wolf explica (1999: 181): "Enquanto este [o público] é pouco conhecido pelos jornalistas, o contexto profissional-organizativo-burocrático circundante exerce uma influência decisiva nas escolhas dos gatekeepers". Assim, podemos compreender que o contexto de editoração e produção de jornais e revistas influencia de modo bastante significativo na seleção do que será ou não publicado.

Por outro lado, não podemos deixar de mencionar a relação do público infantil enquanto receptores com os próprios periódicos apresentados nesta pesquisa, pois, antes de tudo, os 
pequenos autores presumidos eram leitores respectivamente da revista brasileira e do jornal escolar alemão. Nesse sentido, encontramos importante respaldo teórico na proposta conceitual da Educomunicação, “definida como área da prática social preocupada com a natureza dos ecossistemas comunicativos em que os sujeitos estão inseridos." (SOARES; VIANA, 2013:50).

Seus estudos estão, sobretudo, voltados para questões da interação de sujeitos em processos comunicativos e dos modelos de educação formal ou não que podem ser apreendidos pelo público, aqui tomado como um grupo de indivíduos que recebem e constituem sentidos das produções a ele destinados. Desse modo, compreendemos que os veículos midiáticos, enquanto suportes de produções culturais não eruditas, desempenham papel fundamental na formação de seu público alvo, constituído por sujeitos interactantes de processos comunicacionais.

Isto é, a partir da concepção de que o público também age e constrói sentidos, sua relação com a mídia adquire um caráter de formação de um modo mais amplo, pois confere a ele outros repertórios culturais diferentes daqueles difundidos em ambientes educacionais mais formais - como a escola - e, com isso, abre espaço para um maior empoderamento no que diz respeito às suas próprias produções, uma vez que seu repertório mais diversificado garante-lhe mais possibilidades de criação textual e cultural.

A partir do exposto nos itens 1.1 e 1.2, compreendemos que o primeiro passo para a análise dos nossos corpora deva ser a preocupação com uma descrição contextualizada dos periódicos selecionados. Sendo a metodologia pautada numa proposta interdisciplinar, já se espera começar justamente pelos aspectos extra-textuais, ou seja, por aquilo que não está documentado nos veículos midiáticos, mas que são parte preponderante na constituição desses discursos.

\subsubsection{Aspectos comunicacionais na revista brasileira "O Tico-Tico"}

De cunho empresarial, o periódico da Sociedade Anonyma O Malho, "O Tico- Tico" foi concebido pelo jornalista Luis Bartolomeu Souza e Silva como uma revista que, a um só tempo, divertisse e educasse as crianças. O corpo editorial era configurado por outros jornalistas, cartunistas e escritores. Dentre eles, destacamos Manoel Bonfim, pensador político da época, crente de que a educação seria o meio para o desenvolvimento do país. De acordo com os historiadores Mata; Mollo e Varella (2009:5), 
O investimento simbólico na criança seria a saída para a construção deste ideal de nacionalidade. Caberia a estes futuros cidadãos erigir uma nação distinta daquela de tradição colonial e ibérica. Dessa forma, houve um amplo movimento de incorporação da infância aos desafios e destinos da nacionalidade. As crianças e jovens passaram a ser depositários das esperanças e responsáveis pela execução de um projeto nacional constituído no futuro.

É possível observar, desse modo, que a visão de infância adotada pela revista é justamente o oposto do que se defende aqui. Para os idealizadores de "O Tico-Tico", sobretudo Manoel Bonfim, a criança não era tida como membro de uma categoria humana, mas sim como um "vir a ser", um sujeito em processo de transformação. Tratamos aqui de uma ideia bastante positivista, em que um indivíduo só será completo quando for adulto e que é justamente a infância a época de se moldar o caráter da pessoa que ela um dia se tornará mas que ainda não é. Mata; Mollo e Varella (2009), nesse sentido, estabelecem uma analogia entre a concepção de criança e o modelo político da época. Para eles, a criança seria a melhor simbologia para se representar o momento vivido, uma vez que o Brasil era, para os políticos e o povo, uma nação inteira em desenvolvimento. Não é em vão que se acreditava justamente nas crianças como o futuro do país. Os autores afirmam:

Um país em construção exigia um amplo processo de desenvolvimento intelectual e moral. Educar a sociedade, principalmente as crianças, não era responsabilidade apenas da escola. A criança como epicentro da discussão mobilizou uma série de estratégias para dar conta de sua formação. (MATA;MOLLO;VARELLA, 2009: 6).

Observa-se, com isso, que a revista também tinha como função social instruir as crianças para além da educação escolar, com o intuito de formar cidadãos nacionalistas. "O Tico-Tico", apesar de considerar seu público como um receptor passivo, uma folha em branco a ser ensinada, oferecia a seus leitores uma educação extra-oficial, menos erudita e mais divertida. A exemplo disso, observamos, ao longo das dez edições, a presença dos seguintes gêneros discursivos: narrativas, anúncios publicitários, seção de curiosidades, seções de passatempo (com jogos, desafios, moldes coloridos para montar bonecos e desenhos para colorir) relatos de viagens, romances, resultados de concursos, chamadas para novos concursos, poemas e peças para encenação, histórias ilustradas, tirinhas (Mickey, Poopey, Felix e Faustina), e, por fim, a seção de colunas sociais.

Dentre todos esses gêneros de texto, alguns chamaram nossa atenção de modo mais acentuado por seus conteúdos que revelam resultados interessantes para este trabalho. 
Inicialmente, as tirinhas e histórias ilustradas apresentavam, em sua grande maioria, personagens brancos e de classes econômicas mais favorecidas. Havia apenas dois negros: o menino Benjamim, e a menina Azeitona. Ambos eram caracterizados como serviçais, ingênuos, e malandros - e, muitas vezes, eram castigados por isso. As crianças caucasianas, como Chiquinho, Lili, Juca, Tita e Lalá, por outro lado, eram obedientes, espertas e servidas por Benjamim ou Azeitona. Isso pode indicar que a revista dialogava justamente com as crianças como Chiquinho, ou seja, as brancas e de classe social mais abastada, conforme se observa na imagem a seguir, em que o personagem Lamparina é apresentado como um serviçal, sujeito a agressões físicas e verbais quando faz algo de errado:

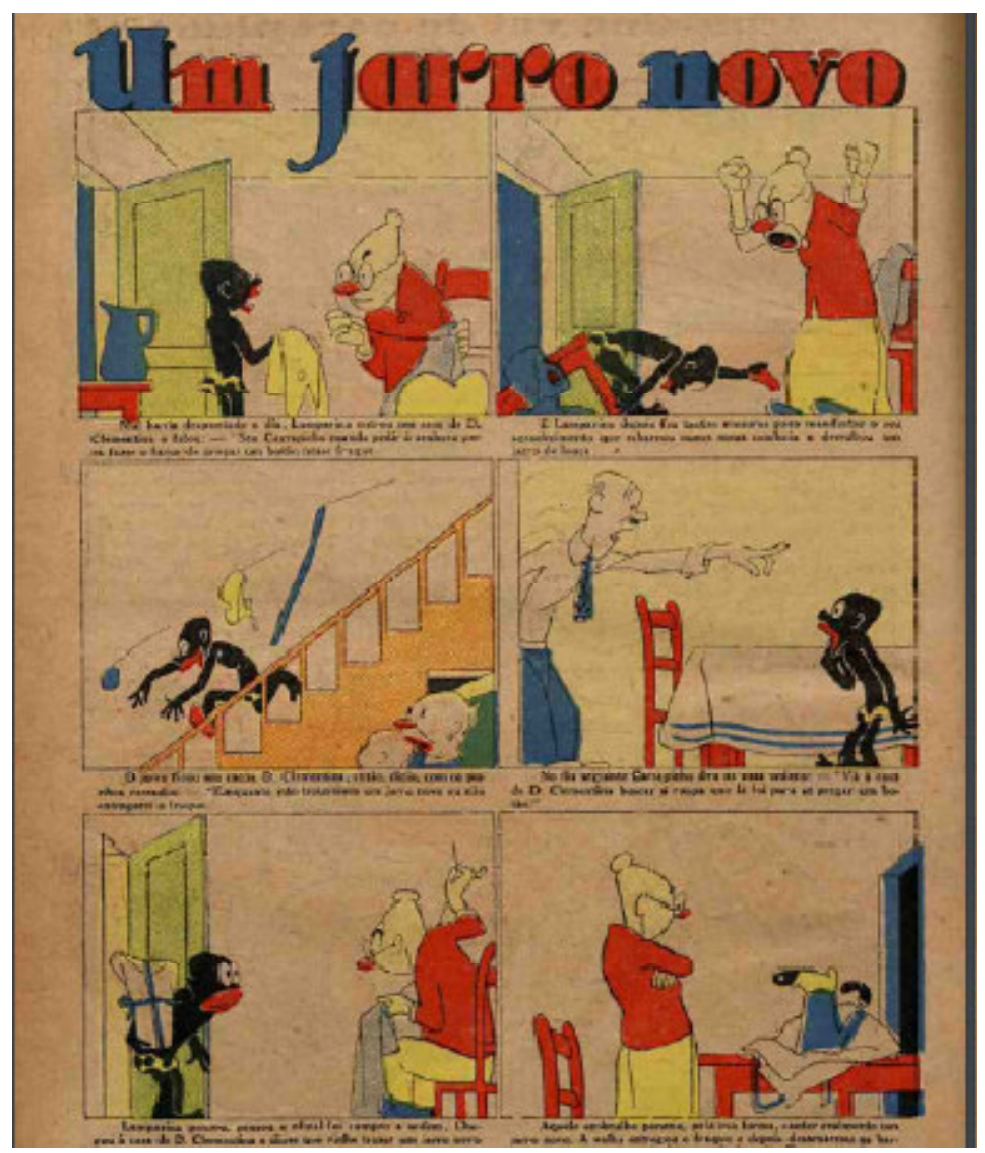

Figura 1: "O Tico-Tico". Ed 1508, agosto de 1934, pg. 29.

Os anúncios publicitários, por sua vez, eram dirigidos ou à toda família ou apenas aos pais, o que aponta para a premissa, por parte dos editores, de que os adultos também liam a revista. É possível prever que a família também se interessava pelos conteúdos, ou que os pais controlavam a leitura de seus filhos. A respeito dos produtos anunciados, observamos que se tratavam, na maioria dos casos, de artigos farmacêuticos - como produtos de higiene, elixires 
e alimentos ricos em vitaminas e minerais - ou de livros e revistas da própria Sociedade Anonyma O Malho, o que indica uma preocupação muito grande dos pais - principais consumidores - com os cuidados da criança, além do intuito da editora de vender mais produtos de suas linhas, - por isso a escolha do Gatekeeper de divulgar também propagandas da própria editora - conforme destacamos nas figuras 2 e 3 a seguir, retiradas da própria revista:

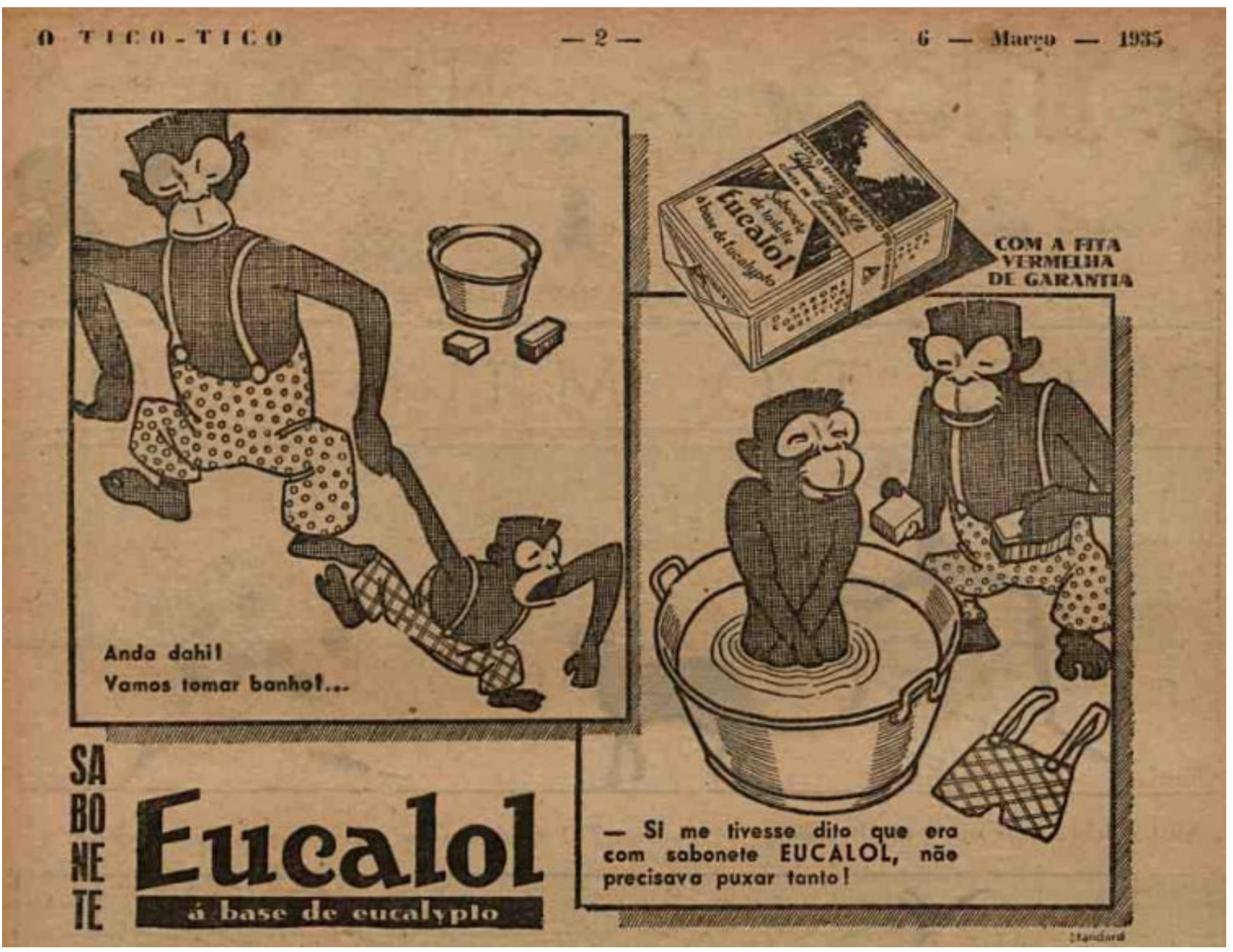

Figura 2:Propaganda do sabonete "Eucalol". "O Tico-Tico", Ed. 1535, março de 1935,

pg. 2. 


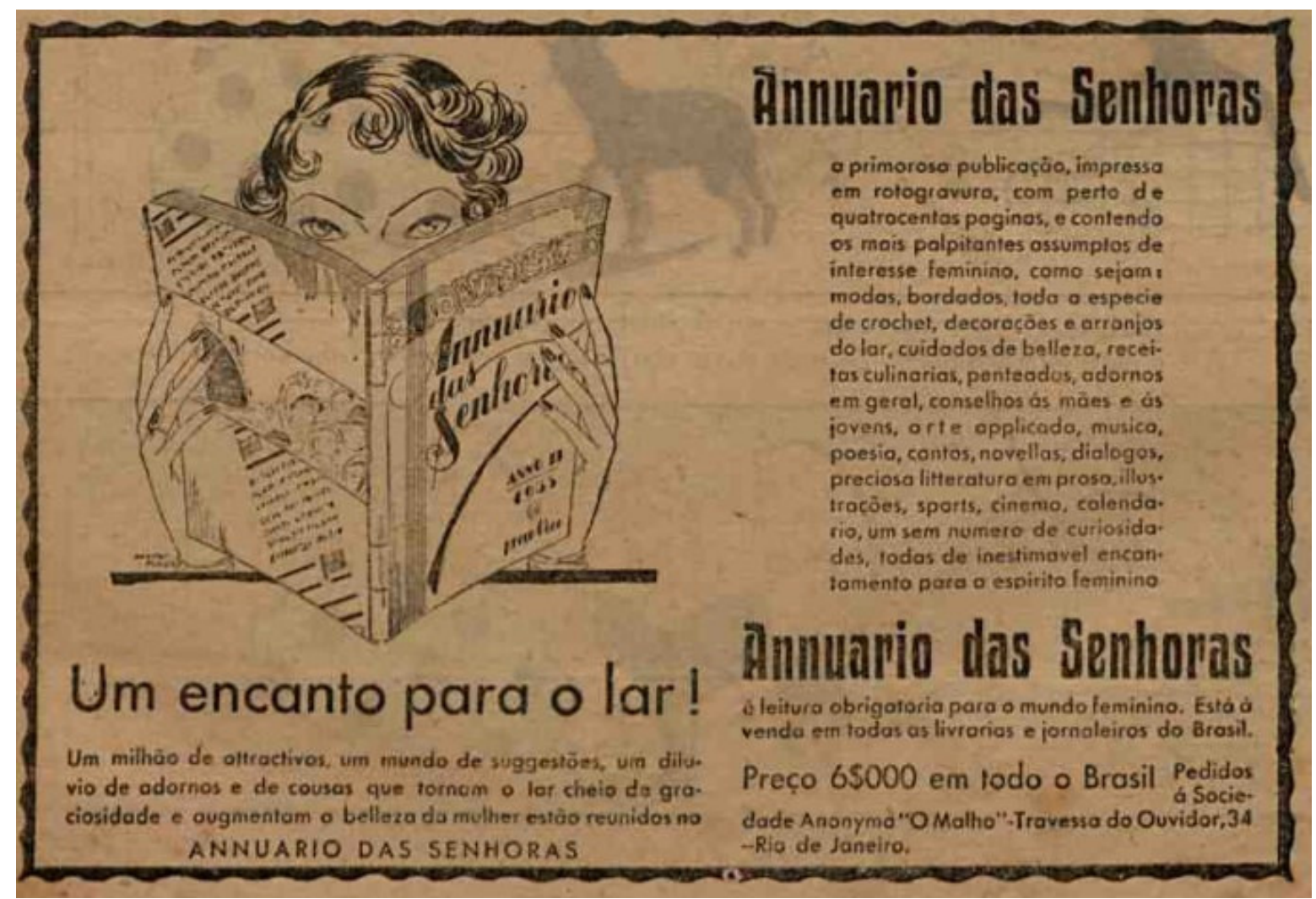

Figura 3: Propaganda de livro da editora "O Malho". O Tico-Tico", Ed. 1535, março de 1935, pg. 2.

Em relação às colunas sociais, presentes na seção O Tico-Tico Mundano, observamos a presença de duas autorias diferentes: a de adultos - os editores - e de crianças - os leitores, conforme se observa na figura. No que diz respeito às colunas escritas pelos editores da revista, foram encontradas notícias a respeito do cotidiano infantil, como batizados, anúncios de seleção para escolas, aniversários e nascimentos. Interessante ressaltar aqui que todos esses eventos narrados ocorriam apenas entre as famílias mais abastadas da sociedade - o que aponta para uma motivação de seleção do Gatekeeper da revista: o prestígio social de alguns leitores em detrimento dos demais.

Os textos produzidos por crianças se caracterizavam como um tipo de subversão à ideia das colunas de fofocas, relatando acontecimentos lúdicos e irreais, apontando as qualidades e os defeitos dos colegas e comparando-se uns aos outros a atores e títulos de filmes do cinema. Isso indica que estas crianças, além de terem acesso às escolas - pois sabiam ler e escrever consumiam outras mídias além da revista. Desse modo, este público mais culturalmente favorecido brincava com diversos tipos de linguagens, recriando, a partir de diversas fontes de leitura, novos textos. Não era um público passivo; ele interagia com "O Tico-Tico" e outros meios de comunicação. Ressaltamos aqui também a grande variedade de gêneros discursivos 
presentes na revista, os quais, provavelmente, contribuíam para um aumento de repertório linguístico das crianças, o qual não era ensinado nas escolas da época.

\subsubsection{Aspectos comunicacionais no jornal alemão "Hilf mit!"}

Sabendo-se que "Hilf mit!" foi um jornal totalmente financiado pelo governo alemão e editado pela N.S. Lehrerverband ${ }^{14}$, podemos compreender que seu principal objetivo de publicação era doutrinar seu público - crianças em idade escolar - para a adesão dos conceitos fundamentais do nazismo: a união nacionalista e o respeito ao Führer, uma vez que seus textos veiculados apontam justamente para a difusão dessa mesma ideologia, como discutimos no terceiro capítulo. A distribuição gratuita da revista e sua obrigatoriedade de leitura nas escolas revela que, apesar de também haver uma noção progressista de infância e de uma preocupação educacional como em "O Tico-Tico", o jornal alemão não tinha uma intenção empresarial ou comercial, pois sua editora era estatal. Num regime como o nazismo, o Estado não visa ao lucro, mas sim à massificação do povo, a fim de perpetuar suas ideologias.

Com isso, a seleção dos Gateekeepers não permitiu que a mesma variedade de gêneros do discurso tenha sido encontrada nas edições de "Hilf mit". O jornal trazia apenas relatos em geral, chamadas para concursos, poemas e jogos de passatempo. Além disso, absolutamente todos os textos apresentavam um único conteúdo: a importância da união e do companheirismo entre o povo alemão. Até as atividades de passatempo eram constituídas de quebra-cabeça com o mapa do país e as caça-palavras traziam termos da ideologia nazista, como podemos verificar na figura a seguir:

\footnotetext{
${ }^{14}$ Associação dos Professores do Nacional Socialismo.
} 


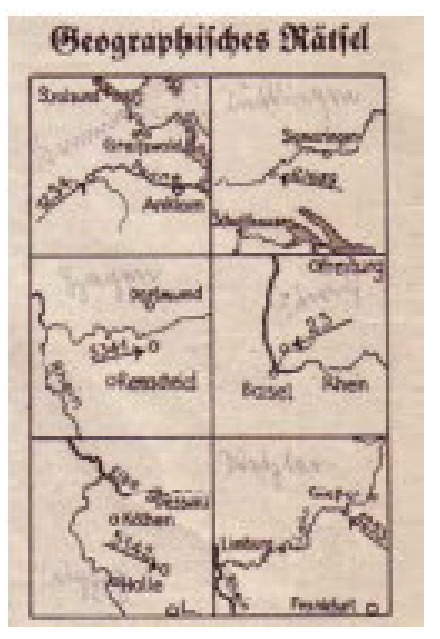

Figura 4: "Geografisches Rätsel" - Em português, "Enigma geográfico", composto por um quebra-cabeças do mapa da Alemanha de 1935, pg. 28

As chamadas para concurso de produção de texto para os leitores tinham como tema a ideia para novas ações em prol de programas do governo, como ocorre no segmento:

As cartas aqui presentes de seus camaradas mostram a vocês o que outras crianças fizeram para a Brigada de Inverno. Como vai isso com vocês? Milhões e milhares de compatriotas deverão ser ajudados também neste inverno. Como vocês querem ajudar nisso? Pensem bem nessa pergunta e então compartilhem conosco suas sugestões. Vocês podem ter sorte, porque nós queremos premiar as melhores ideias. Cada um, de acordo com seu valor, deverá ser pago de cinco a vinte marcos. Agora pensem em algo bastante especial, não algo que todos já tenham feito, mas algo bem inovador. Depois vocês compartilham isso conosco em uma carta. (H3). ${ }^{15}$

Os relatos escritos pelo corpo editorial narravam os feitos de heróis populares de diversas categorias, como militares, camponeses, políticos, entre outros, porém todos seus atos enaltecidos visavam o bem do povo alemão em geral; não se trata aqui de indivíduos que buscam a glória e a auto-promoção, mas sim de pessoas civis ou não que agem num impulso nacionalista e pelo bem do grupo ao qual pertencem, como observamos a seguir, no texto "Drei Männer erobern Ost-Afrika ${ }^{16 ", ~ d a ~ e d i c ̧ a ̃ o ~ d e ~ o u t u b r o ~ d e ~ 1935, ~ e m ~ q u e ~ u m ~ r e l a t o ~}$

\footnotetext{
${ }^{15}$ Tradução nossa. No original: "Die vorstehenden Briefe eurer Kameraden und Kameradinnen zeigen euch, was andere Kinder für das Winterhilfswerk getan haben. Wie steht es mit euch? Auch in diesem Winter soll ja wieder hunderttausend und Millionen armer Volksgenossen geholfen werden. Wie wollt ihr dabei mithelfen? Überlegt euch diese Frage einmal ganz genau, und dann teilt uns eure Vorschläge mit. Ihr könnt Glück haben, denn wir wollen die besten Vorschläge belohnen. Je nach ihrem Wert sollen dafür fünf bis zwanzig gezahlt werden. Nun denkt euch etwas ganz besonders aus, nicht etwas, was alle schon gemacht haben, sondern etwas ganz Neues. Das teilt ihr uns dann in einem Briefe mit."

${ }^{16}$ Em português, "Três homens conquistam a África-oriental".
} 
apresenta todos os feitos do explorador Peters como algo movido por sua paixão pela nação alemã:

Quando os contratos mais importantes estavam assinados, Peters, totalmente cansado, começou a sua contra-marcha. Ele enviou de volta o Conde Pfeil, como comandante da região que ele conquistara para a Alemanha (p. 6) ${ }^{17}$

E essa característica nacionalista que se detecta pela presença dos elementos linguísticos selecionados, como "conquista" possível graças à dedicação e ao esforço de quem "totalmente cansado" tudo fazia pela nação nos revela outro aspecto muito importante: era considerado cidadão alemão, à época, apenas quem correspondia ao ideal ariano. O público alvo do jornal correspondia, então, a crianças brancas, não judias, mas de qualquer classe social. A seleção nessa sociedade, como já discutido no início deste capítulo, era muito mais racial que econômica, ao passo que em "O Tico-Tico" a escolha de ideal do público se voltava para aspectos de acesso à cultura e escolarização, o que estava diretamente atrelado a questões socioeconômicas, apesar de haverem também aspectos raciais implicados nisso.

Os textos escritos por crianças em "Hilf mit!" apontam para a propagação dos mesmos ideais nazistas, o que revela o intuito do Gatekeeper de selecionar alguns relatos que pudessem servir de modelo aos demais leitores. Nas produções atribuídas aos jovens e às crianças, observamos sempre o encaminhamento para relatos de como eles agem em favor de sua nação e de como querem colaborar com o regime. Nada é lúdico nesses discursos, tudo é feito num sentido de se afirmar também como cidadão alemão. Há inclusive o registro de um texto, na edição de outubro de 1935, em que uma garota afirma escrever ao jornal porque fora a mãe quem lhe pedira:

Tenho que finalizar essa carta agora, porque minha mãe disse que eu deveria escrever aos senhores. [....] Minha mãe disse que todas as crianças na Alemanha devem fazer o mesmo e por isso eu escrevo a vocês. Heil Hitler! $(\mathrm{H} 3)^{18}$

Isso indica que a ideologia nazista era não apenas propagada pelo periódico, mas também por outros espaços sociais do cotidiano dessas crianças, como a família e a escola em que a leitura do jornal era obrigatória. Não havia esferas de circulação que não

17 Tradução nossa. No original: "Als die wichtigsten Berträge unterzeichnet waren, trat Peters vollkommen erschöpft den Rückmarsch an. Als Befehlshaber der Gebiete, die er für Deutschland erworben hatte, ließ er den Grafen Pfeil zurück."

${ }^{18}$ Tradução nossa. No original: "Weil meine Mutter gesagt hat, daß ich an Sie schreiben soll, muß ich jetzt den Brief fertigmachen [...] Meine Mutter hat gesagt, das müßten alle Kinder so machen in Deutshcland und deswegen schreibe ich Ihnen. Heil Hitler! 
abordassem este assunto, o que reduzia massivamente o repertório de mundo dessas pessoas, seja em termos ideológicos, culturais, políticos e até mesmo linguísticos. Desse modo, é possível observar que as crianças leitoras de "Hilf mit!" não tinham o menor espaço para seu empoderamento discursivo. Isso porque em seu cotidiano, até mesmo em situações de educação extra-oficial, não eram veiculados textos que extrapolassem a dimensão doutrinária do regime político.

\subsubsection{Correlação entre os dois periódicos do ponto de vista midiático}

A observação dos periódicos "Hilf mit!" e "O Titco-Tico" aponta para uma disparidade em termos de educação informal oferecida. Os leitores de "O Tico-Tico" encontravam na revista um espaço para o contato com novos repertórios culturais, de modo bastante lúdico e educativo. Além disso, as referências ao cinema nas produções textuais das crianças indicam que a revista não era o único veículo de formação cultural não-erudita, o que ampliava ainda mais o repertório de seus leitores.

As crianças de "Hilf mit!", ao contrário, liam o jornal justamente na escola. Nesse sentido, podemos afirmar que mesmo a mídia tinha um caráter de ensino - e por que não de doutrinação - oficial. O fato de o Estado nazista financiar totalmente a produção do periódico indica a intenção de transmissão ideológica, próprio de um regime totalitarista; com isso, a não difusão de outros repertórios culturais e discursivos serviam à manutenção do sistema. Isso não quer dizer, no entanto, que as crianças da época não pudessem, de um modo interacional, recriar e subverter produções culturais a partir de seu reduzido repertório, porém, uma produção de um texto desse caráter não teria o menor espaço para circular nesse veículo, e talvez fosse barrado já no espaço familiar, em que as ideologias do regime então em vigor também circulavam.

No entanto, é necessário ressaltar que tanto a revista brasileira quanto o jornal alemão serviam, de certo modo, como difusores de ideais políticos e sociais em ambos os casos. Com isso, observa-se também um esforço dos Gatekeepers de cada periódico em selecionar textos fossem escritos por crianças ou por adultos - que servissem aos interesses de publicação. Não devemos nos esquecer também que, ainda que os textos tenham realmente autoria de crianças - sobretudo no que diz respeito ao jornal alemão "Hilf mit!" , a seleção de determinados enunciados em detrimento de outros eventualmente enviados à redação do jornal aponta para o fato de que nossa própria recepção dos textos escritos por crianças nesses periódicos está 
bastante atrelada às preferências dos editores, que selecionaram o conteúdo a ser ou não veiculado, o que influencia invariavelmente nossos resultados na presente pesquisa.

Nesse sentido, entendemos importante ressaltar que, em ambos os periódicos, o contexto de produção se dá, não apenas pela seleção do conteúdo a ser veiculado por parte do corpo editorial de tais veículos de comunicação, mas também pela participação ativa dos leitores, seja como autores presumidos - enunciadores de textos das próprias revistas, que respondem ao chamado de participação por cartas - ou simplesmente como receptores no papel produtores de sentido, conforme apontado por Soares e Viana (2013). Desse modo, é possível afirmarmos que esse contexto editorial é construído conjuntamente entre editores e leitores, e não dado de modo pré-estabelecido por uma das partes.

No que se refere ao momento político e social vivido na Alemanha e no Brasil na década de 1930, podemos observar que os valores nacionalistas e de eugenia - racial, no caso do regime nazista, e social, no primeiro governo de Vargas - já se configuravam como modelos mentais de caráter esquemático, isto é, já eram compartilhados pelos indivíduos e aceitos como normas sociais em comum entre a população. Seus respectivos governantes vieram, nesse sentido, como figuras de poder sintetizadoras desses valores sociais.

Os resultados obtidos a partir dessa discussão inicial, em que buscamos observar os dois periódicos situados em seus contextos sociopolíticos e editoriais, mostrou-se de suma importância para a compreensão mais aprofundada dos corpora e continuidade das análises, tendo em vista a possibilidade de se reconhecerem elementos linguísticos que nos levem à identificação das ideologias que circulavam à época e que influenciaram diretamente nas edições de "O Tico-Tico" e de "Hilf mit!". Com base nesses dados, prosseguimos à discussão de conceitos e teorias argumentativas e à análise dos corpora, sobretudo no que se refere às questões sociointeracionais e aos valores e validades argumentativos. 


\section{Capítulo II - ArgumentaÇão: Mecanismos LÓGICOS E SOCIOINTERACIONAIS}

Neste capítulo, abordamos os corpora do ponto de vista argumentativo. Para isso, iniciamos com a descrição do percurso teórico seguido pelos estudos da Argumentação - da Retórica grega aos estudos mais recentes de interação argumentativa. Em seguida, passamos à discussão a respeito da competência argumentativa na infância. O terceiro e último tópico se volta para os elementos referentes às questões sociointeracionais e lógicas presente na argumentação, sobretudo quanto aos valores argumentativos.

\subsection{Percurso Histórico dos Estudos de Argumentação}

A argumentação, tomada como objeto de estudo, não é algo novo. De acordo com Faria (2004), seu surgimento deu-se na Sicília grega, ainda na Idade Antiga, quando a necessidade da reclamação de bens - num contexto em que ainda não havia advogados - criou a demanda por escolas de retórica, com ensinamentos práticos da técnica do discurso jurídico. Sua sistematização ocorreu posteriormente, com a transformação da técnica em teoria por Aristóteles. Em sua obra, o autor se volta, sobretudo, para os efeitos persuasivos dos argumentos, ou seja, para o fato de que as estratégias retóricas também criam ações no mundo concreto.

Dentre as instruções apresentadas na Retórica aristotélica, destacamos dois tipos de classificação apresentados pelo filósofo grego - a primeira em relação aos gêneros retóricos, e a segunda referente aos tipos de provas utilizados em tais gêneros. No que diz respeito à classificação dos gêneros retóricos - deliberativo, judiciário e epidítico -, tal distinção é dada, sobretudo, a partir da identificação dos objetivos de cada texto. Assim, o gênero deliberativo seria aquele que visa ao julgamento de uma ação futura, à deliberação quanto a algo que deveria ou não acontecer na polis. O gênero judiciário é indicado como aquele que tem por finalidade o julgamento de uma ação passada, como um crime, por exemplo. Já o objetivo do gênero epidídico era o julgamento de uma ação presente - a aceitação de alguém ou de algo, sempre muito ligado ao elogio.

Para que alcançassem tais objetivos, os gêneros retóricos se faziam valer de suas provas, que poderiam ter um caráter não artístico ou artístico. De acordo com essa classificação, o primeiro tipo de provas devia ser pensado em seu sentido concreto, como é o caso de 
evidências, documentos e testemunhos - é a verdade verificável. As provas artísticas eram, por sua vez, aquelas criadas pelo orador e poderiam ou derivar de seu próprio caráter (ethos), para conferir mais credibilidade à sua asserção, ou dirigir-se às emoções de seu auditório (pathos), de modo a sensibilizá-lo e comovê-lo; ou, por fim, poderia derivar da lógica e da razão. Em relação a esse último tipo de prova, Pacheco (2007:5) afirma que, segundo os preceitos aristotélicos

Os argumentos lógicos se apresentam sob duas formas: induções, ou o uso de exemplo, e deduções, chamadas em retórica de 'entimemas'. O entimema, ou silogismo retórico, é aquele tipo de silogismo em que as premissas não se referem àquilo que é certo, mas àquilo que é provável, e tem importância fundamental para a retórica, já que na maioria dos casos que estão em jogo, nem sempre se pode basear a argumentação apenas naquilo que é verdadeiro, mas apenas no que é verossímil.

Dada essa característica da lógica, que confere a verossimilhança aos discursos, esta prova artística foi, segundo Plantin (2008), a base da recepção da Arte Retórica na modernidade, a qual passou a considerar as demais figuras de estilo como mero ornamento, deixando em segundo plano seus efeitos persuasivos. Com isso, ao fim do século XIX, a Retórica passou por um intenso período de descrédito no meio acadêmico francês, subtraindolhe apenas a lógica - muito valorizada na área da Matemática e Física, pois permitia a elas o uso da dedução.

Esse status conferido à Argumentação só começa a ser repensado na metade do século XX com o surgimento de duas obras marcantes com novas discussões a esse respeito, a saber: o modelo da "Coerência Argumentativa" de Toulmin, e a "Nova Retórica" de Perelman e Olbrechts-Tyteca, publicadas em 1958. Essa última obra em especial se caracteriza como um marco nos estudos argumentativos, pois inaugura a ideia de Argumentação como um objeto de estudo. Nessa direção, vale lembrar que tais estudos linguístico-discursivos voltados à argumentação nasceram, então, da lógica (Toulmin) ou dos estudos da Filosofia do Direito (Perelman e Olbrechts-Tyteca). Essas perspectivas foram utilizadas pelos estudiosos para buscarmos compreender o funcionamento do discurso no que diz respeito à persuasão e ao convencimento nessas áreas do conhecimento. Portanto, apesar de as pesquisas desses autores não estarem vinculadas diretamente à Linguística, observa-se que já apresentavam uma concepção de argumentação voltada no discurso.

Importa ressaltar que a teoria de Perelman e Olbrechts-Tyteca além de, como proposto por Aristóteles, resgatar o raciocínio dialético e de retomar a preocupação em relação aos efeitos persuasivos, ou seja, no fazer agir pela linguagem, também frisa, em diversos 
momentos da obra, a importância em se ater a um auditório específico e, a partir dele ou de sua concepção, desenvolver estratégias argumentativas. O conceito de auditório é, então, definido pelos autores "como o conjunto daqueles que o orador quer influenciar com a sua argumentação". (PERELMAN E OLBRECHTS-TYTECA, 1996 [1958]:22) Esta preocupação com o interlocutor do texto argumentativo, seja ele escrito ou oral, está fortemente ligada a uma concepção sociointeracional da língua já naquela época. Isto é, bem antes dos estudos sociointeracionistas despontarem, esses estudiosos previam as (re)ações do outro para a construção de uma dada mensagem. Apesar de nem Perelman e Olbrechts-Tyteca e tampouco Aristóteles apresentarem uma proposta linguística sociointeracionista, uma vez que viveram em outro período, parece possível dizer que foram precursores dessa linha teórica.

Toulmin (2001 [1958]), por outro lado, lança seu olhar sobre uma outra característica da Argumentação: a lógica. O autor, fortemente influenciado pela filosofia da linguagem propõe, um modelo monologal da Argumentação, no qual se busca observar o encadeamento do raciocínio lógico-argumentativo, de modo a categorizá-lo dentro de um discurso contínuo, sem interrupções de seu interlocutor, ou seja, um monólogo. Dentre as críticas ao Modelo da Coerência Argumentativa, de Toulmin (2001 [1958]) e de Perelman e Olbrechts-Tyteca (1996 [1958]) destacou-se, à época, a perspectiva de Ducrot (1987), pelo viés da Semântica Argumentativa em que o autor propõe trazer a argumentação da lógica para dentro da Linguística, com a Teoria da Argumentação na Língua, em que, partindo do pressuposto de que a Argumentação ocorre também no cotidiano, é possível observar os mecanismos discursivos dessa atividade em diversas situações comunicativas, formais ou não.

Essas duas propostas, a Teoria da Argumentação e a Argumentação na Língua, distinguem-se por sua concepção de argumento. Enquanto para Perelman e Olbrechts- Tyteca se trata de um refinamento da linguagem que visa à persuasão de seu público, para Ducrot - a partir do momento em que o autor se volta também a enunciados não eruditos - este recurso se constitui no processo "de encadeamento de proposições que conduz a uma conclusão" (AMOSSY; ZAVAGLIA, 2007:124). Assim, é possível afirmar que, enquanto os primeiros se preocupam com o fazer agir no enunciatário, o segundo se preocupa com o fazer pensar do enunciador.

Buscamos, neste trabalho, observar recursos argumentativos de enunciados atribuídos a crianças, tanto num ponto de vista mais interacional, como proposto na Teoria da Argumentação - ou seja, para o fazer agir no enunciatário - como no plano lógico, de acordo com a Argumentação na Língua - o fazer pensar do enunciador. Antes, porém, vemos 
necessário proceder a um breve estudo da competência argumentativa das crianças, de maneira a provar a viabilidade de se debruçar sobre uma análise de textos de autoria infantil.

\subsection{Competência e Produção Argumentativa na Infância}

Assim como ocorreu com os estudos de mídia para a criança, as pesquisas em argumentação pouco se voltaram para o discurso infantil, pois a maior parte dos estudos argumentativos teve como foco o discurso jurídico e de grandes veículos de comunicação. É possível que isso decorra do fato de as principais pesquisas de Psicologia da Linguagem, como é o caso de Piaget (1970), defenderem que a criança passa por dois momentos em seu desenvolvimento linguístico - a fala egocêntrica e a fala socializada, ou seja, em sua concepção, o indivíduo, inicialmente comunica-se consigo mesmo e, aos poucos, mais precisamente em torno dos seis anos de idade, passa a se voltar para os outros, socializando-se por meio da linguagem.

De acordo com Koch (1993), todo texto, oral ou escrito é argumentativo e interacional. Desse modo, parece possível afirmar que a criança poderá argumentar de fato quando já tiver adquirido a chamada fala socializada. No entanto, não devemos esquecer que toda e qualquer produção linguística - na qual se inclui a argumentação - é social. Ora, se a criança aprende a falar numa atividade dialógica com os adultos em seu entorno, desde o primeiro balbucio sua fala já é interacional e, portanto, socializada.

Faria (2004:49) afirma sobre isso que:

[...] adquirindo a linguagem nesse processo de interação, de ajuda, é inconcebível que a criança crie para si uma linguagem fechada, monológica, pois esse traço não está presente na linguagem por ela adquirida. Não se pode falar nem em retroceder, pois não houve um momento anterior em que a linguagem não se apresentasse dialógica, isto é, sem um direcionamento para um outro.

A autora tece uma crítica, desse modo, à proposta de Piaget na medida em que não concebe a língua, em momento algum, como algo desprovido de seu caráter social. A partir disso, Faria lança mão de um estudo sobre a produção argumentativa desde muito cedo na vida das crianças, em pesquisa realizada com um corpus de 30 horas de enunciados produzidos por crianças de 3 a 6 anos de idade, situadas no contexto escolar e familiar. Os resultados obtidos pela autora apontam para o fato de que 
[...] desde cedo, a criança desenvolve estratégias para envolver, para convencer o interlocutor, sendo, portanto, portadora de uma linguagem com plena competência para a argumentação. Essa competência argumentativa é um processo dinâmico, que se desenvolve cada vez que entra em contato com novas situações, em diferentes interações e envolve múltiplas capacidades. (FARIA, 2004: 58)

É necessário, porém, ter sempre em mente que essa capacidade argumentativa da criança ainda está em desenvolvimento e, por se tratar de um processo sociointeracionista, diversos fatores ligados ao contexto das enunciações podem influenciar a rapidez e a qualidade de suas produções em termos de argumentação. Entendemos, assim, que os recursos argumentativos presentes nos textos produzidos por crianças também necessitam de mais estudos e observações, pois indicam características linguísticas de indivíduos que se encontram ainda numa fase de apreensão dos mecanismos lógicos e sociointeracionais e seus efeitos persuasivos, nesse sentido, propomos, no próximo tópico, uma discussão a respeito de tais mecanismos argumentativos.

\subsection{Sociointeracionismo e Lógica na Argumentação}

Recentemente, os estudos argumentativos têm-se desenvolvido cada vez mais no plano discursivo, colocando a Argumentação como um elemento inerente, constitutivo de todo discurso, seja numa situação mais tradicional e fechada - como no discurso jurídico - ou cotidiana. Nesse sentido, buscamos em Habermas (2012), filósofo e sociólogo alemão, a posição quanto aos estudos do atos comunicativos a partir de da Teoria Crítica da Sociologia, em que se propõe, na "Teoria do Agir Comunicativo", observar elementos linguísticos enquanto características sociais, também fundado numa ideia de comunicação enquanto (inter)ação. Porém, para o autor, a língua em si não se caracteriza como uma atividade, mas sim como um processo, que ocorre de modo cognitivo e social na vida dos indivíduos, que a constroem coletivamente. Em sua obra, o autor adota uma concepção de argumentação retórica, uma vez que essa é a linha que, desde a Antiguidade, vem-se preocupando com o processo composicional da Argumentação.

Observar a Argumentação enquanto processo é se voltar para seus mecanismos de produção e outros elementos que a influenciam. E, sabendo-se de seu caráter sociointeracional, torna-se necessário compreender como tais características interferem nesse 
processo. Partindo dessa concepção, encontramos em Aquino (2015:239) a noção de que argumentar é, sobretudo, negociar com um interlocutor. Segundo a autora,

A respeito da interação, podemos dizer que ela comporta peculiaridades que se apresentam em relação aos participantes e seus objetivos interacionais. Os estudos a ela relacionados vêm apontando para o fato de que o processo interativo funda-se na negociação, na busca de acordos [...].

A Argumentação, enquanto processo linguístico que visa justamente à persuasão, configura-se como uma característica fortemente permeada pela negociação, uma vez que seu principal objetivo é fazer o outro agir conforme o desejado. Para isso, é então necessário negociar não apenas ideias, mas, sobretudo, relações sociais de poder.

Um recurso argumentativo relacionado à negociação e que podemos observar nos corpora selecionados diz respeito ao objetivo para o qual se voltavam as crianças no momento de produção de seus textos. Embora não tivesse tratado da argumentação na infância, tomamos a posição teórica de Plantin (2008) a respeito da orientação argumentativa dos textos também como uma característica lógica que permeia o processo argumentativo, uma vez que todos os argumentos apresentados apontam para a conclusão do discurso, ou seja, para o objetivo que se pretende convencer ou persuadir. O autor afirma que

Do ponto de vista logicoepistêmico, observamos que, para a AnL (Argumentação na Língua), a conclusão já está presente no argumento, que ela só faz reformular. Essa visão aprisiona qualquer argumentação em uma espécie de círculo vicioso, 'P, logo P'. (PLANTIN, 2008: 36).

Antes, porém, de iniciarmos as discussões a respeito das negociações para as quais os textos aqui analisados apontam, entendemos ser necessário proceder a uma apresentação da estrutura de nossos corpora, de modo a compreendermos melhor os mecanismos de funcionamento das estratégias argumentativas. Nas próximas seções que seguem, tratamos da estrutura dos enunciados e do da apresentação dos objetivos argumentativos de cada texto

\subsubsection{Estrutura e encaminhamento argumentativo em "Hilf mit!"}

No que se refere ao periódico "Hilf mit", cujos textos escritos por crianças se configuram como relatos cotidianos e que mostram a importância da união do povo alemão, apontando para uma negociação em consonância com o regime, temos a busca pela aceitação ou reafirmação de uma ideologia do Estado, conforme apresentamos os textos facsimilados a seguir. Ressaltamos que o corpus selecionado dessa revista é constituído por diferentes textos, 
que não correspondem a uma única seção. Por conta disso, optamos por apresentar a análise da estrutura de cada um dos enunciados isoladamente.

\subsubsection{Festa da colheita no Landjahr}

O primeiro texto do corpus alemão a ser analisado, Entfest im Landjahr - Festa da colheida no Landjahr ${ }^{19}$, inicia-se com a imagem de seis rapazes uniformizados e em posição militar, porém, ao invés de portarem armas, trazem consigo pás. Essa foto a seguir indica um deslocamento da disciplina militar para outras atividades civis - como a participação na colheita junto à população rural - , o que nos leva a presumir a importância dada à disciplina marcial nos grupos juvenis da época fomentados pelo governo de Hitler, como é o caso do Landjahr. Na legenda da foto, lê-se: "O Grupo das Pás não pode, é claro, faltar no desfile. ${ }^{20 "}$ No início da segunda página seguinte, uma outra foto também chama a atenção por apresentar um rapaz ensinando uma criança mais nova a usar uma arma. Em sua legenda consta: "Um chefe do Landjahr mostra ao pirralho como se deve manusear a besta ${ }^{21 "}$. Assim como a primeira, esta imagem aponta para a importância conferida ao treinamento bélico a que as crianças do Landjahr eram submetidas.

Logo após o título da seção, é inserida uma outra imagem em que um garoto sobe num mastro e, abaixo dele, outros meninos assistem a ele. Na legenda, a explicação: "Abaixo da guirlanda da colheita está pendurado um anel com muitos prêmios bonitos. Quem galgar a alta barra, pode trazer para baixo um prêmio ${ }^{22}$." Outras imagens semelhantes são apresentadas nesse texto, como as duas últimas da página seguinte, em que crianças estão levando a guirlanda da colheita e praticando esportes, o que aponta para espaços de lazer previstos para os membros do Landjahr, porém sempre relacionado à disciplina física.

\footnotetext{
${ }^{19}$ Grupo instituído pelo regime nazista e composto por jovens em idade escolar, cujo principal objetivo era fornecer ajuda à população no final do outono, de modo a que todos estivessem preparados para enfrentar o inverno que estava por vir. O projeto teve origem na República de Weimar e, em 1934, foi instituído como serviço obrigatório para formandos da $8^{\mathrm{a}}$ série. Essa tradição continua na Alemanha do século XXI, com a possibilidade de trocar o serviço militar pelo serviço social, o "Zivildienst".

${ }^{20}$ No original: "Die Spatengruppe der Landjahrungen darf natürlich im Festzug nicht fehlen."

21 "Ein Landjahrführer zeigt dem Pimpf, wie man die Armbrust handhaben muß."

22 "Unter dem Erntekranz hängt ein Ring mit allerlei schönen Preisen. Wer die hohe Stange erklettert, darf sich einen Preis herunterholen."
} 


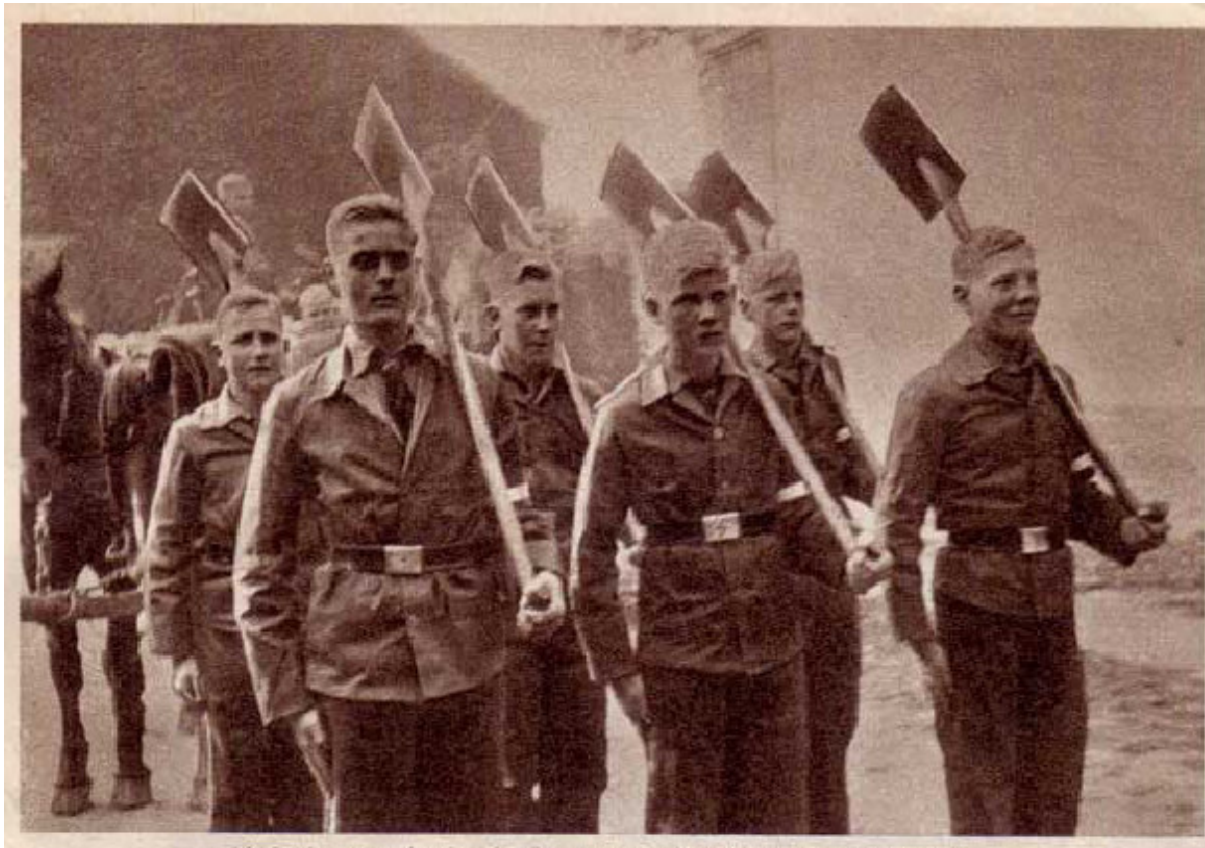

"Rod) nie bat Reuenoorf fold ein Erntefeit gefeiert mie 1934." S)eini, Der Grositabtjunge, hat ons (đ)warz auf meís beftätint. Seine (Stofinutter bemabrt einen Iangen Brief Davon mit vielen anderen Sditeiben ibres Entels in ibrem Ebenbol 3 tafts den auf. IIny am Sonntag, wenn fie eine fitlle Stumbe hat, lieft fie die Beridfte Syeinis, ber fo an[dhaulid und to grünblid) fdreibt, baßs fie felber glaubt, in ibrem Dorfiein au meilen, in bem fie einft als rimo zwifáen 2Biefen umo pidfern geipielt bat.

Eo rafälttig olättet f̧rau Ef hagen mit ibren arbeitsharten 5)anden bas zertnitterte Bapier, lejt fith bie Brille auf uno figidt fic an, zu lefen. Da tönen von

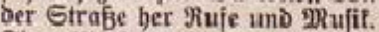
Sie will bina usidjauen, Dod) fie fieht nixhts als ben grauen 5ins terhof, bie verftaubten Dädber und ein Stüđđgen 5immel. Die alte frau feuf3t. Dann bujat ein Radieln über ibr fyurderts gefidst. Gie erimnert fid, $\mathrm{Das}$ fie beute unten Ernteleft feiern.

\section{Erntefeft im Landjabr}

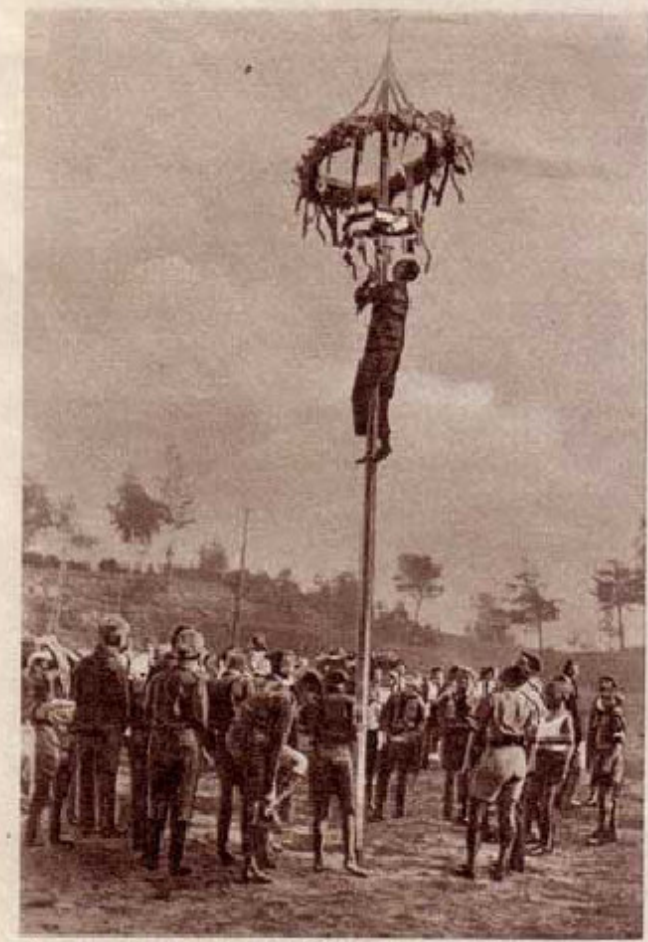

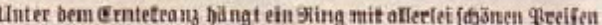

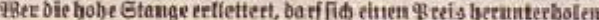

2Iud in ber grofeen Gtabt Finb Die Beute fröhlid) unb denten an ben Bauern, Der ilhnen Das täglidje Brot idjafít.

2lber ijgr feini! Der ijt oraufen in शReuendorf, aud heute mie nor einem. Sabr, Uno fie lieft zum 50. Mole moht Die Brieje ihres Entels Sier, Der

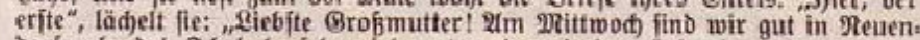

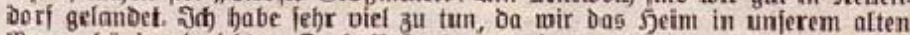
Burggebäube einriditen. Deshalb heute nur ein paar Beilem. Id bin fo frob

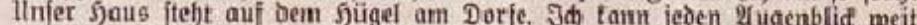

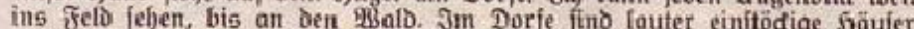
und eine 2Bebrfirche aus Branitfteinen. Bafb merbe id $3^{\text {at einem Bauer }}$ arbeiten geben. Erft miliffen wir aber Dronung ternen. Und benfe bir: ein:

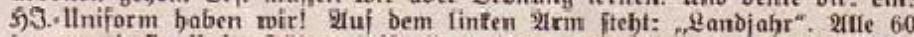

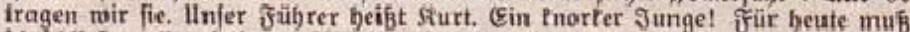

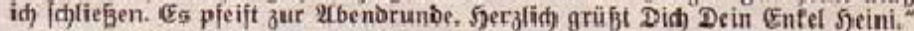

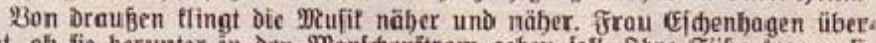
legt, ob fie berunter in Den Dtenfideniftrom geben foll. 3bre Fübe tragen fie foum. Da fälit ibr sBlid auf den langiten Brief, den Sjeini ibr geldyrieben bat.

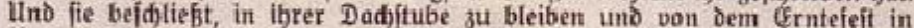

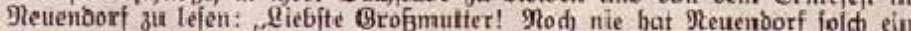
Erntefeft gefeiert! Das fannft Du mir glauben! Das liegt aber aud baran, Daß̉ mir Lanbjahrjungen Dem ß̌eft auf bie Beine geholfen haben.

Freilid), eine ganze 280ht) baben mir es norbereitet. Sturt, unfer fager, feiter, rief eines Zages den Drisbauernfüffrer ins 5)eim. Der follte ung fagen,

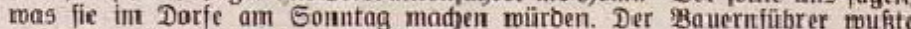
anfangs nidht vief zu fagen. (Fr meinte, einige Bauern wollten überhaupt nid)t mebr mitmadjen, meil fie ibren "Erntebahn" nicht im Geptentiber feiern buriten wie bisher. Da baben twir bänn nod ben gehrer und ben alten Schäfer geholt. Der ersäblte, was ex bon feinem Bater von ben früberen (Entefeiten gebört hatte. (Er fannte audi nod einen aften Erntefprum und zeigte, mie fie

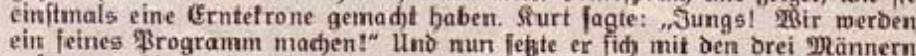
zufarmmen him, und bafo war ein fanger Bettel fertig. Bor allem murbe Der Feftzug feftgelegt. \$as mir felber madien wollten, Das murbe aber nimt per raten. 2Bir haben nun in den Radimittagsitunoen mäd)tig aefdiafif: Die

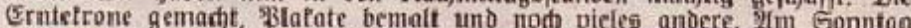
vormittag gingen mir in bie Rird)e. (E5 mar febr feierlid), als nir burd bag alte 23 ehrturmportal id)ritten. 2Im \&itar maren Befreibegarben aufgeftellit, und am Iauffitein jitand ein Sorb mit f)erbitfrüdten; Das war ein Dpjer fuir bie Drtsormen. $2 B$ ir hatten aus bem Seimgarten aud baju beigéfteuert. $2 B i r$ fargen das \&iés mit: "Pun dantet alle Batt!

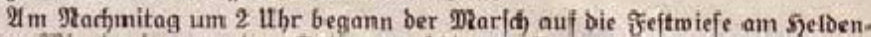
bain. 23ir buriten an ber Spibe marjhieren. Bornemeg ging unjere franarengruppe, dann fam ber Erntefranj, ben bie Jungen au Stangen trugen.

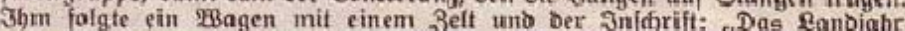

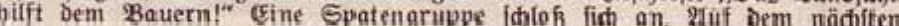
EBagen maren zmei Rameraben, Die zeigten unfere eigenen Ianbomirtíchaits Itdjen Erzeugniffe: Riefentürbifie, aber aud) unfere Giänife, Sthafe uno Touben Da haben Die शeuenDorfer aber gelad)t. Sd) ritt auf Dem ßjerbe meines Bauerit mitten im 3uge. Dann folgten sungvolt, $B D D$, uno bie übrige Dorfiugeno. Die Sđthule twar auf befränsten tisagen veritaut. Danad) tamen Edmiffer und Gdmitterimnen und die Dorifapelle. Die Reuendorier boben

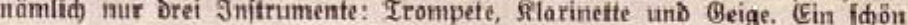


gepoljterter 2iBagen fubr bie älteitten Bauern uno Bäuerinmen. Den Sdilu bildete ein Ernterwagen mit Der lesten (Sarbe, bem .2Alten". Das ift eine be bänberte Strohpuppe, die auf Dem bein letalen wor fornfter Sonnenifoin. Du fannt Dit benten, liebfte Dma, wie wir afle vor frettoe glithten! Mun aber erit Die FFejtwicke! linfer feurt bielt eine bannige Inipradje an bas ganze veriammelte Dorf. Det Drtsbauernfühter Iuo uns Darauf zu Saffee und foudjen ein. 29ber mir liegsen uns nidjt viel Beit zum Sipjen. Unifer Erntefranz murbe auf eine hobe Stange gebradit und unter ibm ein Reifen mit allerlei Gejibenten bejeftiat. Dann bié es: "Stangentlettern". EBir Netterten mit ben Dorfiungen um bie Wette. Id holte mir ein feines Rotiz: budh herunter. (Erid) hatte eine 2rmbruit gemadjt. Damit [ajolien wir nadj bem hölzernen 5)abn auf einer Stange, ben batten toir uns felbit geidjnibst. Iidh habe

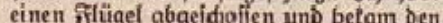
Dritten $93 \mathrm{rei}$, cine munshermonito. Bei den Metifipielén foruten wir Gtabst. jungent unjere firäfte mit ben Batiern= jungen meffen. \$ir fónitten gut ab. meil mir ein balbes sahr tüdstig Spart getrieben batten. Die Mä́del fah in) Sade hüpfen uno Eierlauf madhen. Id) batte aber menia Beit zum Buídauen: Derm id muste beim rafperielpiel mithelfen. Bon Seltbahnen bauten wir ein Theater. $D$, wie haben bie Reuendorfer geladit, als unjer felbitgejdinibter sajperle ben "Sommernadststraum" ipieite! Etwas

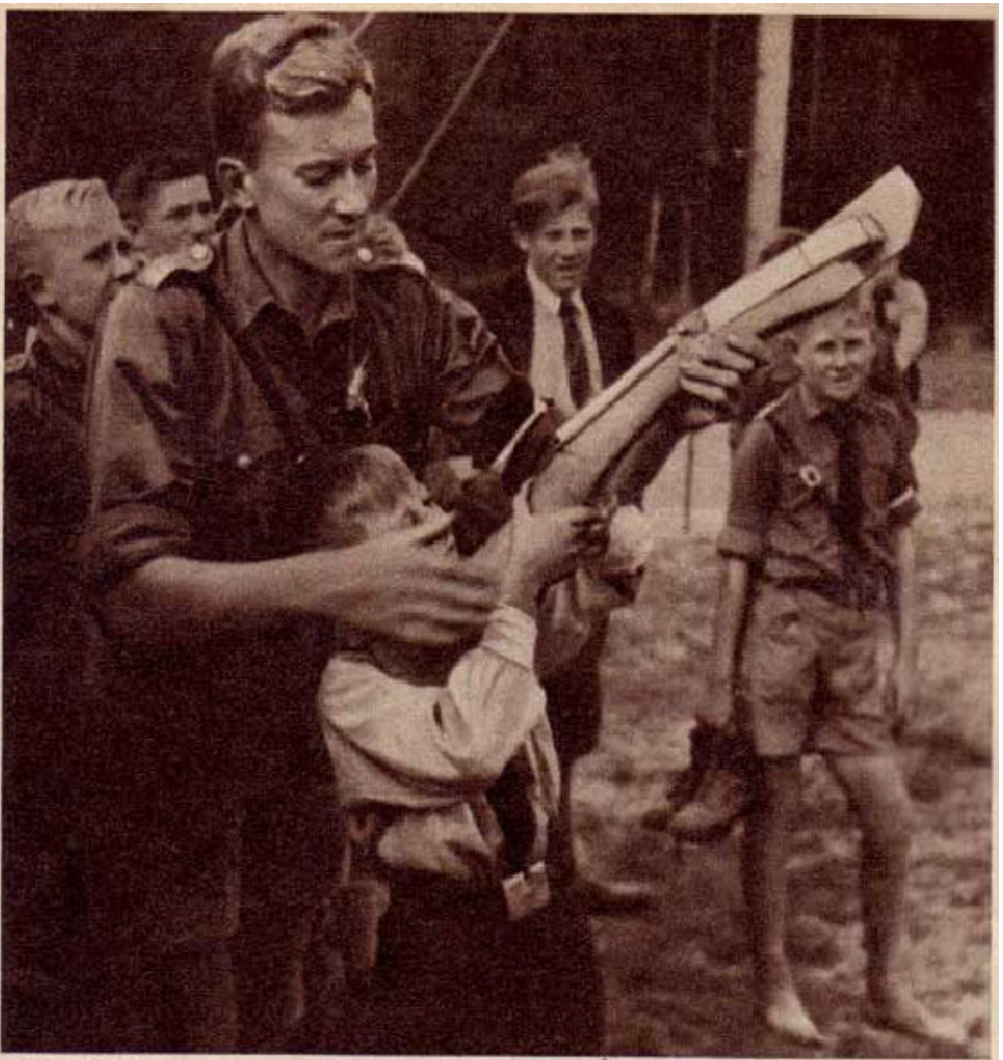

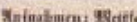

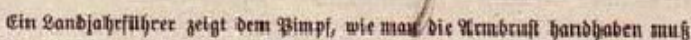

gebadit. Es war ein Bäntelfängerfieb mit Bilbern, bie bie ilberidrift trugen: „Das Sdjredgeipenft in Srein. DReders. borf". Damit betamen alle üblen Mlederer eins auf ben S)ut. - Qber bann eridjoll ein Irompetenitó. Zilles eifte

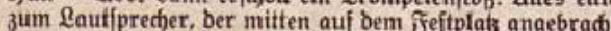
war. Dente Dir: Wir hörten ben Jüubrer! 2̌fu bem Buide berg fprad) 210olf Sitler zur gleidjên Stuinde ju allen Deutidien sauern, und es mar ofs ob ar mitten unter

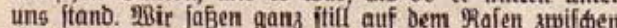
Den शeuenoorfern, uno Das mar Der fdjönite थugenblid Des Iages. 2(ud) bie Bauern, die anfänglián nidjt mit feiern moliten, maren frob uno fto $f_{3}$ über oos, mas fie veruahmen. 2ils die Sonne unteraegangen mor, traten mir in einen sing am fyeloenthin fouer brannte auf unb mir fpraden sen Gpredithor: cire bes Meltfrieges. Dann erflang Maridmufit, uno beim

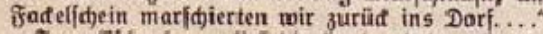

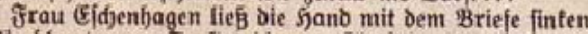
Sile (dhaute zum jenfter hinaus. Sie fab aber nidht mebr Die grauen Däder und Edhorniteine der inicienitoot ibren 2lugen erfibien bie Jeftwiele von PReuentoorf, mo ibr Seini aud diefert Gonitag tweilte.

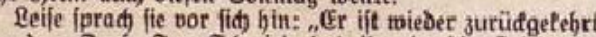
in das Dorf. Der Edjuites hat ibn in die Qebre ge nommen. Die \&anomajhinen baben es ifjm angetan. (Ex mill ein Selier Der Bauern merben - auf feine Beile. Seini, fo bift ou mieber in die Fujptapfen beintes lurgros. vaters getreten. Der ging hinter Dem Bifluge ber. Bott legne bid, mein Junget"

\section{Worte des fülorers}

Zille Sdowanfungen find ant of

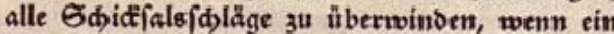
gefunbes 23auerntum vorbanden ift.

Golange fids ein $\mathcal{D}$ olf auf ein farkét 2Batterts. tum zurüct yieben fann, wirbes immer uno inmer wieber aus oiefem heraus neue Kiraft fö̈pfen.

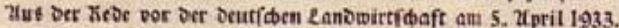

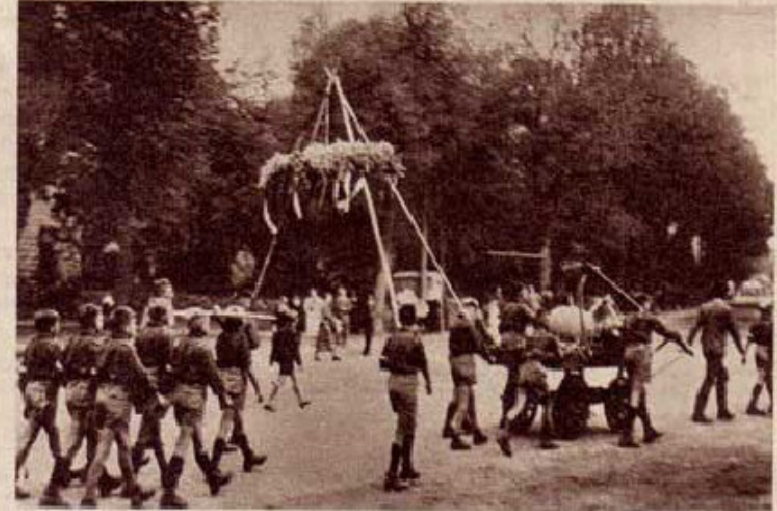

Sungen uou Ranbjabe tragen ben centettams

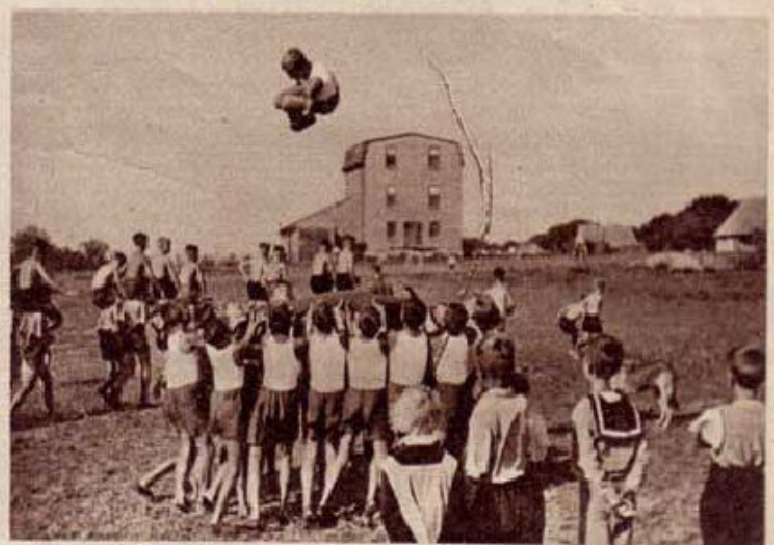

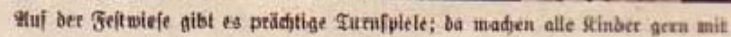


Em relação ao texto, observamos que este é estruturado como uma carta - de autoria infantil - que está sendo lida por uma avó. Há, portanto, dois autores nesse único texto e seus objetivos são diferentes. Enquanto o menino se preocupa em relatar na sua carta as conquistas de seu grupo escolar obtidas na união da "raça alemã", há um outro narrador em terceira pessoa que mostra a emoção sentida pela senhora ao ler a carta de seu neto - Heine, conforme destacamos:

[...] 'E imagine só: temos um uniforme da Juventude Hitlerista! Sobre o braço esquerdo está escrito: Landjahr. Todos nós 60 o vestimos. Nosso Führer se chama Kurt, um excelente rapaz! Por hoje é só. Está soando o toque para a patrulha da noite. Saudações cordiais do seu neto Heini ${ }^{23}{ }^{24}$

De fora, a música tocava cada vez mais próxima. A Sra. Eschenhagen se pergunta se deve ir no fluxo das pessoas. Seus pés mal a carregavam. Então seu olhar repousa sobre a carta mais longa que Heine escrevera-lhe. [...] [Grifo nosso] $(\mathrm{H} 1)^{25}$

No excerto acima observamos que, enquanto a avó se volta à situação de maneira mais emotiva - a expressão "seu olhar repousa sobre a carta" indica uma relação de afetuosidade em relação aos relatos -, o garoto vê a situação com o entusiasmo de quem age. Apesar de haver uma concordância ideológica, o objetivo do texto expresso pela voz da criança está muito mais voltado para enaltecer sua importância no regime - a menção ao "uniforme da Juventude Hitlerista" com a identificação do grupo Landsjahr "sobre o braço esquerdo", que o menino afirma vestir ao lado dos 60 colegas o coloca como integrante ativo do movimento político; já a avó continua a ver tudo como um fazer infantil. Ela própria volta a se sentir criança com as cartas de seu neto, ao se imaginar brincando em sua terra natal a partir da leitura, como se observa no segmento:

[...] E aos domingos, quando ela tem um tempo tranquilo, lê os relatos de Heini, que escreve com uma letra tão vívida e bem-feita que ela mesma acredita estar em sua vilazinha brincando entre os campos e as lavouras. [Grifo nosso] (H1). ${ }^{26}$

\footnotetext{
${ }^{23}$ A terminação do nome do garoto em "i" - de Heine para Heini - indica a flexão do diminutivo na língua alemã, o que sugere ser este um apelido afetuoso utilizado pelos familiares.

25 Tradução nossa. No original: " 'Und denke dir: ein HJ-Uniform haben wir! Auf dem linken Arm steht: "Landjahr". Alle 60 tragen wir sie. Unser Führer heißt Kurt. Ein knoler Junge! Für heute muß ich schließen. Es pfeift zur Abendrunde. Herzlich grüßt Dich Dein Enkel Heini.'

Von draußen klingt die Musik näher und näher. Frau Eschenhagen überlegt, ob sie herunter in den Menschenstrom gehen soll. Ihre Füße tragen sie kaum. Da fällt ihr Bild auf den längsten Brief, den Heini ihr geschrieben hat. [...]"

${ }^{26}$ Und am Sonntag, wenn sie eine Stille Stunde hat, liest sie die Berichte Heinis, der so anschaulich und so gründlich schreibt, daß sie einst als Kind zwischenWiesen und Ackern gespielt hat.
} 
O texto, no entanto, não se encerra com a carta ou com a narração de sua leitura, mas sim com a "Palavra do Führer" ${ }^{27}$, segmento retirado de um discurso de Adolf Hitler, proferido em abril de 1935 e que tratava da importância da união do povo alemão. A presença dessa citação indica uma intenção por parte dos editores do jornal em inserir outros discursos além dos atribuídos às crianças.

${ }^{27}$ No original, "Wörte des Führes" 


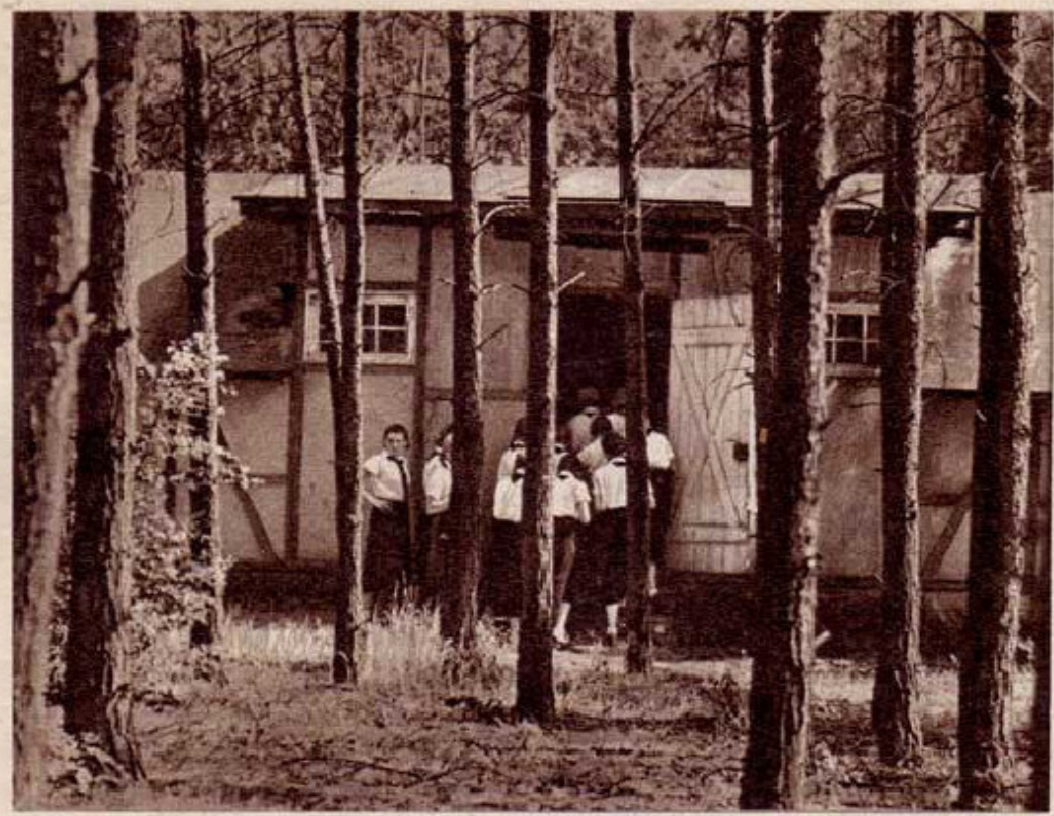

3m stiefernwalb oerifedt liegt unier 5 eim

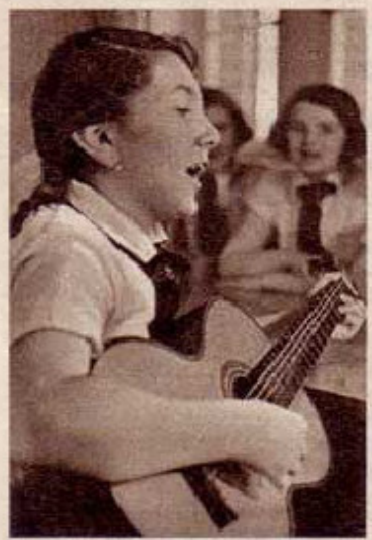

Ein Mabc fpicite jeben qforto \&aute, und wit fernten viele alie solfoweifert

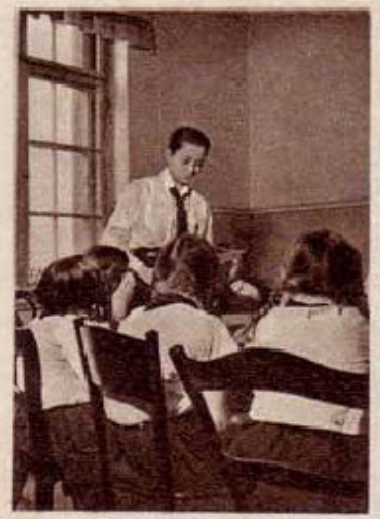

9uth erzäblt

vom Reinsjugendtag it Gotedam
Miảd

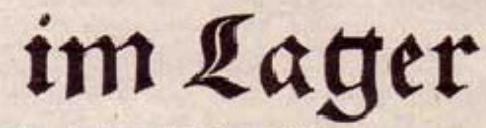

Draughen in ber märtijdgen fyeide, mit." Seit zmei Stunden marfdieren wir fidon. 8wanzig

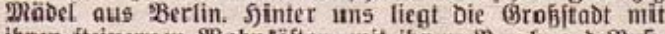

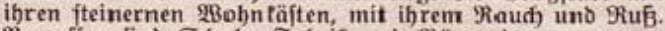
Bergeffen find Sđdule, frabrit und Büro; benn vor uns liegt eine Wodhe Siameradidaft, eine 230 be voller Sport unb geiftiger Sd)ufung.

Fieine von uns ift mübe vom fangen Dariditeren. Bald müffen mir ja aud) Das Bief, unjer feim in der

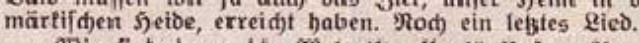

"2Bir finb jung. bie WBelt ift offen!" unfere 2lugen futhen Das Biel. Da liegt aud fifon im fiefernmald ver, ftedt unfer 5eim. Ein Rommando: "2rbteifung - balt! Beggetreten!"

Wir ftno angelangt.

Stunden der fameraðjajait.

Bier Tage find mir iefat fonon bier. Jeben Tag Epiel uno Eport. Zubenos fingen mir हieder oder erzählen uns gegenfeitig vort unjerem \&eben in der Stabt. Beitern bat Kuth), unjere Füherin, aus Den Jabren Des IRamples beridhtet. Sie bat im Dittober $1932 \mathrm{am}$...Reidjsjugentota" in Botsoam teilgenommen. Butin erĩten MRale in ber Ge: idjinte Deutidilands, fo erzäblte Ruth, haben über bunberttaujeno Jungen und Mäbel in einer gewaltigen frunogebumg fid) Ju Deut(a)land und unjerem füibrer

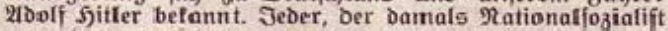
mar, batte es fámer; denn bie verhebten Bolfsgenofien

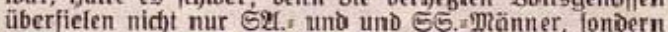
febr oft aud Jumgen und stäbel der sitterjugeno. WBir haben Damals zufammengeitanben", batte Berda gefagt, BBir baben uns vor niemandem gefürdftet uni ftets $3 \mathrm{u}=$ fammengebalten in Ireub unb Reib." $2 B i r$ aber, bie wir erit nad ber PRadtibernabme 311 eroolf Sitfer fanden. wollen unfere Srameraben aus ber Rampizeit jum 23orbilo
Uno über uns Die Zahne, fie raujd)t unb fnattert "Damit unier $301 f$ mieber ftart uno einig merben follte. nebmen unb, fo wie fie bamals, aud heute mit ben anderen fameraofdafit: (id) sulamimentibalten. $\mathrm{Db}$ Madol oder

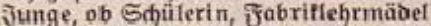
ober Stenotupiftin. 2Bir alle fino Deutidie - ein einiges Boit. Inifer Eager bier in ber märtilden Feide aber if ein fleiner 2ustdmitt aus ber

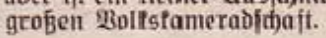

Bom Rüđjendienif

und anberen neflen Sadjen.

Die 3ungen in Der 53 . haben, wie wir immer mieder in ihren Jुahrten= berid)ten lefen, eine ziemlid grobe Bange vor bem stididendienft und fehen ibn als Strafoienft an. Bei uns war Das ganz anbers. Jebe wollte fod)en, und Ruth batte ibre Drïbe, Die Rühenarbeit zu verteilen. Dabei ift die 2urbeit nidit etwa einfad). Der Rüd)endienit muste immer eine Stumbe friber aufitehen, oamit bie anderen zur redten Beit ibr Jrüh: andue betamen. Jü jwanzig humgrige Mäbel aber Stullen zu fómieren und belegen, Das ifit eine ziemilid) anjtren= genoe 2ir beit. Eo mandie non uns bat ibre voreilige Preloung sur 2rrbeit bald bereut, menn es aud) feine redht zugeben molite.

$23 a s$ es bei uns au effen gab? 3hr merbet ftaunen. Nur eimmal in ber ganzen 28ode Erbswurit. Sonjt Whildynubein, (Bulajd), Brubreis, Stoht und Rartofielfuppe mit \$Bürftchen. (Die Jungen twirrden ba fider vor Reio geplabt lein, bätten fie es ge: fehen) Beforment bat es uns immer. 2Iud bas eine Mal, als unierm fiuten Der Mild)reis anbrannte.

Dit baben mir abenos fange ge: fungen. Ruth) fannte fo viele idoöne alte 2oltslieder, Die fie uns auf ber Laute voripielte. Eine Menge Reues haben wir dabei gelernt; bent unjere ₹̄ibrerin exjählte un-s immer gleid ठаза, wie dieje \&ieber entítanden uns wann fie gefungen wurbent. Das wann fie gelungen turbeti. Das fingen wir bie \&ieber nod einmal fingen noir

\section{zä̀อใ im Dienft.}

IBist ihe, oic ibr nidyt am Reben uno Ireiben unjeres Mäbelbundes

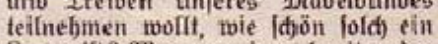
\&ager ift? Rer nur eimmal mit ande= ren Däbein, Ramerabinnen, braufsen gelebt bat, bet Sport und Spiel, der vergifst bas nie. $\xi_{s}$ maren fójöne Stumben, ernite und beitere. Erfuillt vom Geifit ber frameradidait, jenter Rameråídaft, bie man nidt jútibern uno beidsreiben Pann, fonbern Die man erleben mus, um fie zu ver: itehen. Da figen wir nebeneinanber, Drabel aus allen Sthiditen unferes Bolles. Mrädel aus dem Diten, Ptor: Den, Siben uno $23 e$ iten Berlins, uno fino Dod) nur eins: beutide Máabel. Die in Der Sitleriugend threm Bolte mit Iat und Einfas zur Seite ftehen follen.

Mand) eine von uns bat erit bier im Rager veriteben gelernt, mozı fie in unjerem Drabelbund ift und was wir molien. In (Bemeinjidaft mit ben anderen iteft nummehr aud fie be: wußst zu ben ت̇̌abnen und Eimpein unferes Bundeg als Mäbel im Dienit. für Deutínland.

\section{4}




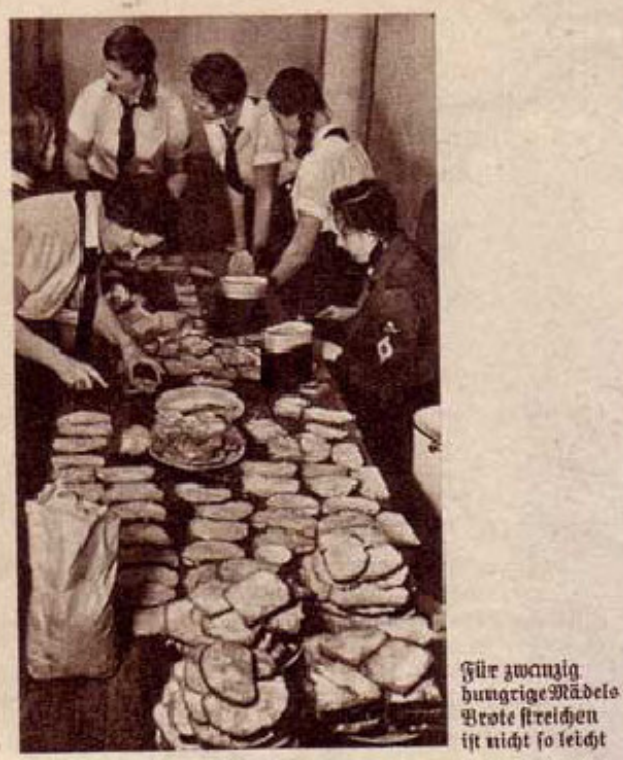

2Alles Gute hat ein Enbe.

freute ift der legte Ing im fjeidelager. Säuber: tid fiegen Die Tornifter fápon gepadt an ben Fuß enden ber peinlidfit fauber gebauten Betten. 2Bir ittehen zum lebten gRale um ben Iilid herum, rei-

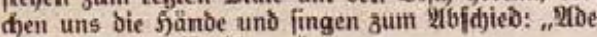
nun zur guten Rad)t. . .

Dorgen frilh, um fed)s Uhr, wito uns ein [djriller अfeifenton zum 2lufftehen rufen, und Dann geht's heim. Burüd in bie Brobitabt. 3uriad an oie 2rrbeit.

Bis zum nädfften Rager.

23. 23.

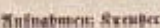

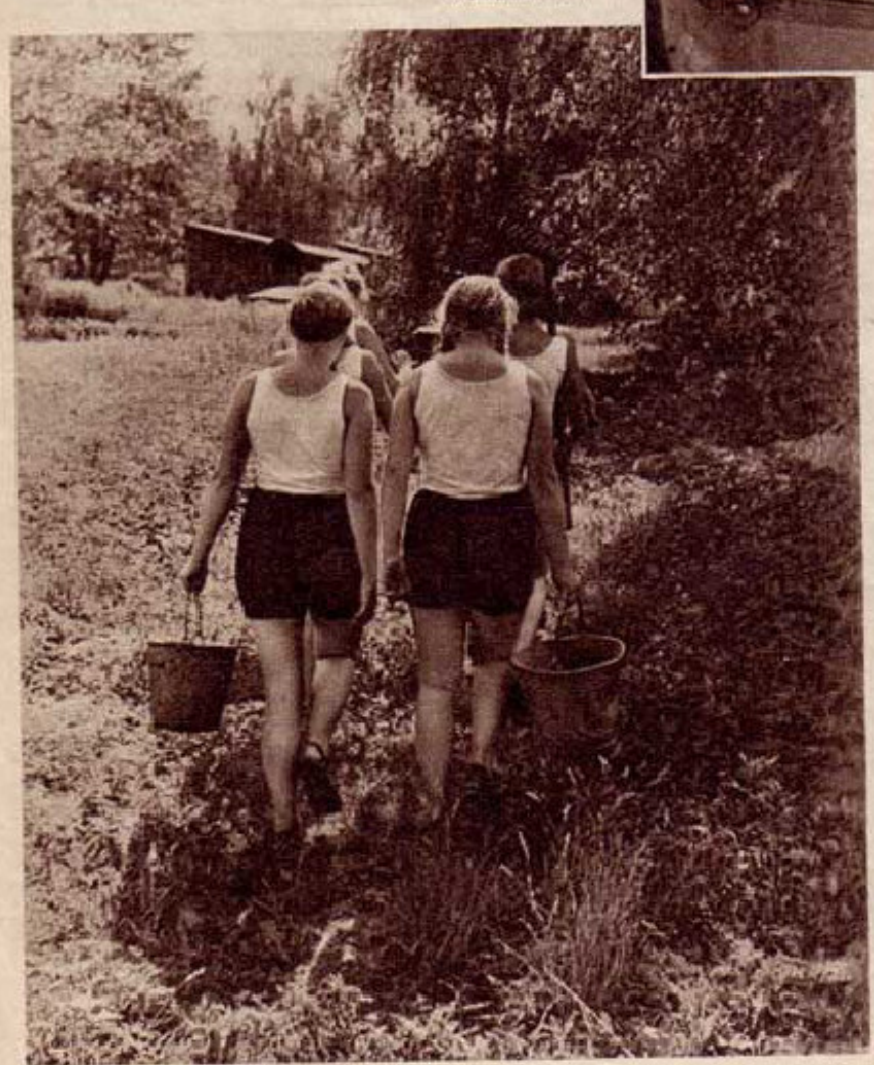

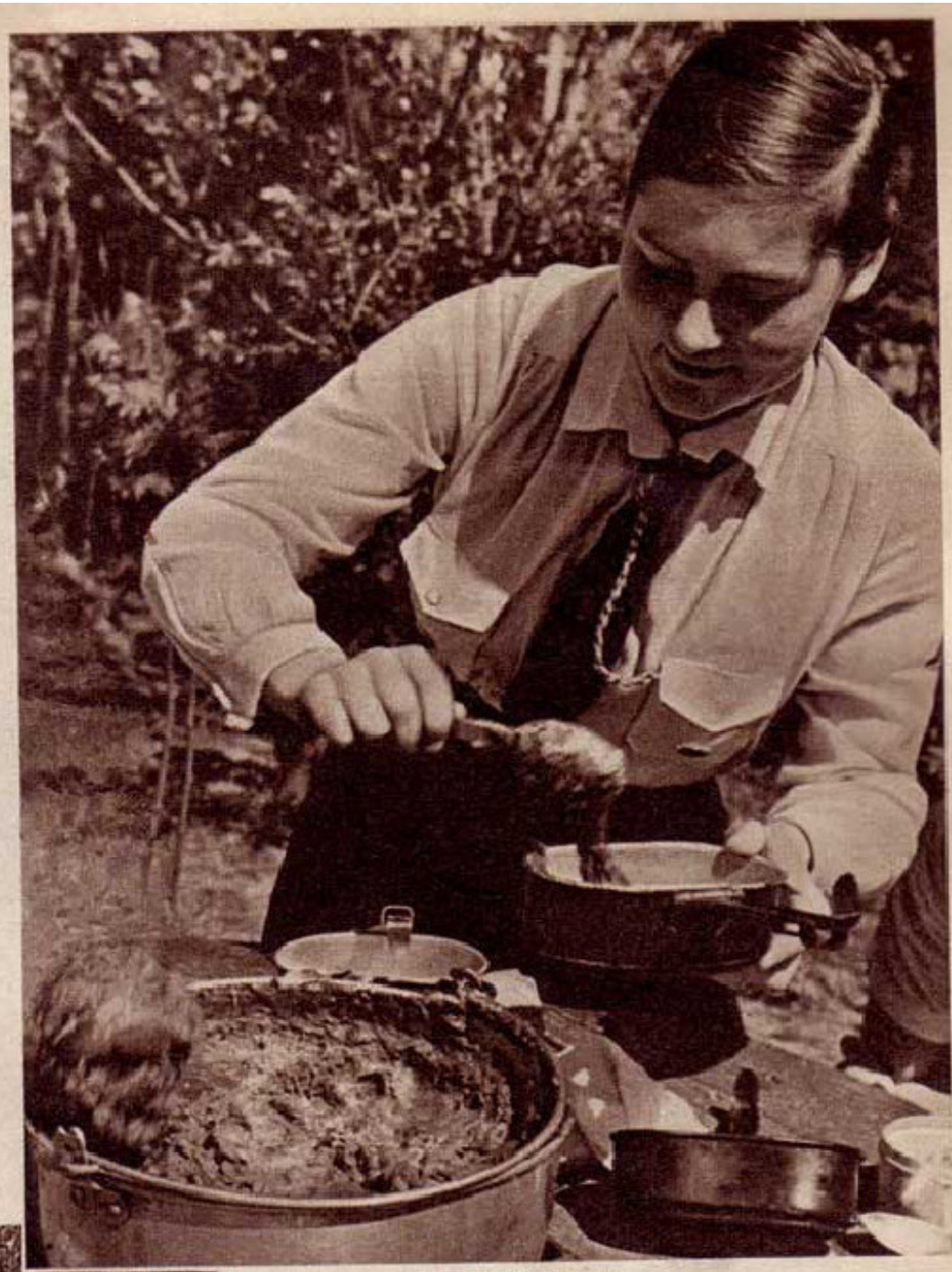

Eine vom stidjendienif

\section{Beftentnis}

Muttex, börft ou bas jaudbenbe Eieb, Das in jumgen fiolonnen vorifbersiebt? Eo ruft mid,, «s lodt niid),

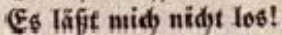

Die $\mathfrak{z}_{\text {elt }}$ if io weit -

Uutb bic Seloniudt io grof.

Mutter, wär' iđ babei!

Mutter, föteft bu sie Falynen fnattetn,

Die uiber ben Sitlerunäbeln flattern?

E⿱ fingt fo feltiam in meinem 8 lut.

Es tlingt fo freubig, fo voller פ)tut.

Die Fabne tuft

llub loft io gut.

Muttex, wär' id babei!

Wutter, idb barf uidt abjeits fteben, Ğör meines Blutes Sdprei!

Die jungen fjerjen brennen wit Flantuen

Unb fingen zujanmen

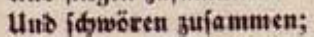

2Itle, bie beutident Blute entfanmen,

Mutter, fint alle babei! Gicete Steinnilat

Goure, Quft unb and - Otrebeit

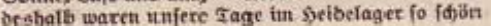


Em Menina no Acampamento (Mädel im Lager), como já sugerido no título, encontramos o relato da experiência de uma garota em um acampamento da Liga Federativa de Meninas. A seção é composta por fotografias e dois textos - o relato de W. W. e um poema - Confissão (Bekenntnis ${ }^{28}$ ) - assinado por Grete Steinrück. A primeira imagem estampada no artigo mostra meninas em frente a uma casa, provavelmente o lugar do acampamento, conforme indicado na legenda: "No bosque de pinheiros está escondido o nosso abrigo, modesto mas aconchegante e impecavelmente limpo. ${ }^{29 "}$ A referência à limpeza e a outros serviços domésticos são características não observadas nos textos de autoria atribuída a meninos. Na página seguinte, três outras fotos reafirmam a importância conferida a essas atividades no acampamento - no canto esquerdo superior, a preparação dos pães, no meio da página, o trabalho na cozinha e, por fim, a imagem de meninas carregando água.

Outros tipos de atividades são representados nas fotos da seção - a de uma menina tocando violão, cuja legenda explica: "Uma menina tocava violão toda noite, e nós aprendemos muitas canções folclóricas antigas ${ }^{30 " ;}$ e a de uma outra garota mais velha ensinando as demais, com a seguinte descrição, logo abaixo da imagem: "Ruth conta sobre o Congresso juvenil em Potsdam ${ }^{31 " . ~ E s s a s ~ d u a s ~ i m a g e n s, ~ a o ~ c o n t r a ́ r i o ~ d a s ~ d e m a i s, ~ n a ̃ o ~}$ representam meninas realizando atividades propriamente domésticas; no entanto, chamam nossa atenção na medida em que representam a doutrinação que ocorria nesses acampamentos - uma menina, geralmente mais velha, ensina músicas tradicionais ou relata sobre sua participação no apoio ao regime.

O texto atribuído a W. W., apesar de ter a estrutura de um relato de acampamento, é constituído também como um convite às demais meninas da "raça alemã". O uso da expressão "até o próximo acampamento" - destacado no excerto que segue - sugere o tom de um convite a seu interlocutor a participar de tais eventos:

[...] Nós estamos de pé ao redor da mesa pela última vez, damo-nos as mãos e cantamos em despedida: 'Ode agora ao bom poder...'

Amanhã cedo, às seis horas, um som de apito estridente nos chamará, e então vaise para casa. De volta à cidade grande, de volta ao trabalho.

Até o próximo acampamento." [Grifo nosso] (H2). ${ }^{32}$

\footnotetext{
${ }^{28} \mathrm{O}$ termo possui dupla denotação, podendo referir-se também à confissão no sentido religioso.

29 "Im kifernwald versteckt liegt unser Heim, bescheiden aber anheimelnd und blitzsauber."

30 "Ein Mädel spielte jeden Abend Laute, und wir lernten viele alte Volksweisen"

31 "Ruth erzählt von Reichsjungentag in Potsdam."

${ }^{32}$ Tradução nossa. No original "Wir stehen zum letzten Male um den Tisch herum, reichen uns die Hände und singen zum Abschied: 'Ode nun zur Guten Macht...'

Morgen früh, um sechs Uhr, wird uns schriller Pfeifenton zum Aufstehen rufen, und dann geht's heim. Zurück an die Arbeit. Bis zum nächsten Lager. W. W."
} 
A referência aos tipos de atividades realizadas no acampamento, como dar-se as mãos e cantar "Ode ao bom poder" - hino cujo título remete à reverência ao regime nazista, então vigente - aponta também para o enaltecimento do agir em coletividade e da partilha para com seus semelhantes, sobretudo no âmbito ideológico, como sugerido pela escolha da canção mencionada.

Em seguida ao relato, é publicado na mesma seção, o poema de uma outra garota, que versa sobre o chamado à participação da Liga Federativa de Meninas. No texto, a enunciadora conversa com sua mãe sobre a canção que ouve dos grupos, uma canção que "chama" e "atrai". O chamado não é apenas da canção, mas é também da "bandeira" nazista, como destacamos na tradução integral do poema a seguir:

Mãe, você está ouvindo a canção exultante, que passa nas jovens colunas?

Ela me chama, ela me atrai, Ela não me deixa!

O mundo é tão vasto -

E a saudade é tão grande.

Mãe, eu queria estar lá!

Mãe, você ouve as bandeiras trepidarem, que palpitam sobre as Meninas de Hitler?

Cantam estranhamente no meu coração.

Cantam tão amigavelmente, tão cheias de coragem.

A bandeira chama

$E$ atrai tão bem.

Mãe, eu queria estar lá!

Mãe, eu não posso ficar de fora,

Ouça o grito do meu sangue!

Os corações jovens queimam como chamas

E cantam juntos

E juram juntos

Todos, que vem de sangue alemão,

Mãe, todos estão lá! [Grifo nosso] $(\mathrm{H} 2)^{33}$

${ }^{33}$ Tradução nossa. No original:

"Mutter, hörst du das jauchzende Lied,

Das in jungen Kolonnen vorüberziehen?

Es ruft mich, es lockt mich,

Es läßt mich nicht los!

Die Welt ist so weit -

Und die Sehensucht so groß.

Mutter, wär' ich dabei!

Mutter, hörst du die Fahnen knattern, Die über den Hitlermädchen flattern?

Es singt so seltsam in meinem Blut.

Es klingt so freudig, so voller Mut. 
Ressaltamos também a recorrência de termos como "juntos" e "sangue", bastante relacionados à ideologia nazista, uma vez que a união do povo deveria ocorrer apenas entre aqueles pertencentes à "raça alemã", ou, nas palavras da enunciadora, "todos, que vem de sangue alemão". Observamos, com isso, que esse poema exalta o entusiasmo de participar de um grupo juvenil do regime, como também de se reconhecer como pertencente à "raça ariana".

Die Fahne ruft

Und lockt so gut.

Mutter, wär' ich dabei!

Mutter, ich darf nicht abseits stehen,

Hör meines Blutes Schrei!

Die jungen Herzen brennen wie Flammen

Und singen zusammen

Und schwören zusammen;

Alle, die deutsche Blute entstammen,

Mutter, sind dabei!" 


\section{Wir wollen mithelfent}

Eine Jungenidgaft fammelt papier.

Int vorigen $23 i n t e r$ war es. Wir faß̧en vergnügt uno munter in unferem neuen, jefb jttapezierten Seim uno fangen pfundige Randstnedts: uno fabrtentieder. Unjer Seim fab einfad) tnorte aus, da fiēs fid nid)ts gegen fagen. Wir batten einem alten 马ierdejtalf, Der längit von feinem Befiģer wegen "Unfäbigeit" aufgegeben mar, mit Silfe von ungeheuren $\mathscr{B}$ affermengen, vieten Reiften uns gefdnorrter Tapete nieder ein "menidfifínes

BËblid) aber murbe bie gute Stimmung burd fauten Frad unterbroden. Surt und (Erid) batten fid in bie 230 lle getriegt. unterbroden. Surt uno erid) batten fich in bie 250 lie gefriegt. Du bajt bod geftern Stubenoienit gehabt uno haft alfo für Sauberteit 3 u forgen. Wie fiebt bas aber nod) aus? Da liegt ia nod) Der ganze Beitungsfram vom Tapesieren. Meinft ou viefleidt, id räume Den weg, blos weil bu gejtern zu faul zum Stubentoienft marit?" WBüteno fitieß Rurt mit bem fuß gegen einen Stapel after Beitungen, Die in einer Ede bes Fyeimes lagent. „280 foll id, benn ben Ruatid) hinbringen", gab (Erid) müten๖ zurüd, "Denfít ou, id) madie eine 2Ittpapierwarenbandiung auf?"

Unbemerft mar injwifden unfer Jungenid)aftsfühbrer fjans eingetreten. (Erid) mieberholte nod einmal fnurrend feinen "Bar nidht fo burmm, Der Boridflag."

Bir triegten natürfid, alle einen Sajted, als unfer Jungen. id)aftsfübrer auf eimmal hinter uns ítand. "\$aßit einmal auf" jagte er und wies auf ben Stapel Beitungspapter. "Das if nod) lange nidjt genug, bas mußs nod, oiel mebr merben." Furt, ber am anberen Iage Stubenbienit batte, madite entiejte 2rugen. "Wiefo nod mebr?" - "Das follt ihr gleid bören! \&ullo wir fammein jegt affe alten 3eitungen, Dann verfaufen wir fie in Der 2fitmarenthandiung. Das Betb aber überweifen mir ber Wointerbilfe." - Das gab ein lautes Sallo bei uns. Da waren wir natürlid) alle Dabei. $2 \mathrm{~m}$ andern Tage jahen bie 5aus: berwohner (a)werbepadte Jungen im Seim aus= uno eingeben. "230 mollen die bloB mit bem ganzen aiten 3eitungspapier bin?" fragte fid) mand)er topfídüuttelno. $2 B$ ir aber idjleppten mit Fetiereifer weiter Beituingsballen auf Beitungsballen in unfer

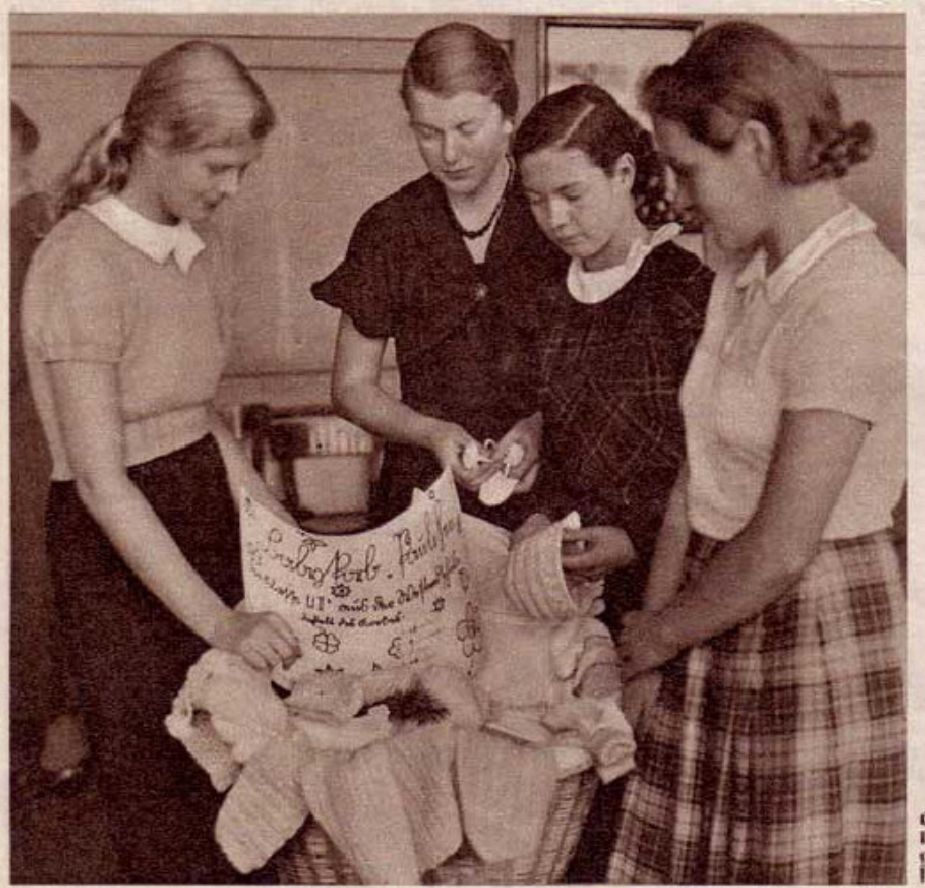

Syeim, in bem jeft faft tein freies ffleddhen mebr war. Dan vertuben wir bas ßapier auf einen Sanbtwagent, unb binein ging es in oie Staot zum 2fitpapierwarenbanoler. 3manzig Dtar erbielten wir ausgezahit. Der frändler gab uns nod) zme

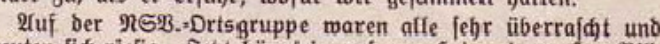
freuten fid) riefig. Jebt bängt in unferem fjeim ein grobes Bilo von unjerem fribrer, das hat uns ber Drtsgruppenfeiter ges íhentt und bazu geidjrieben: "Mteinen jungen Rameradent fur ibren Iateinfab im 2 interhilfswere."

Weinflajđen für die Winterbilfe.

Erit baben fie afle gefadht, als id, es in Der Rlaffe erzählte. 2fber nadjoem baben die meiften gefagt: „Du, Das ift ja einfad) piundig. Näbites Mal madjen twir bas aud), bas mit ben Beinflajden für die Winterbilfe."

Unjer Rebrer batte uns in Der Deutidjftunde einen Iangen Bortrag über bie Bolfsgemeinidjaft und die \$interhiffe gebaften. Er $r$ te Junge or mian, of munge oder Mtadel, dieles 2lufbauwert bes Jübrers unteritüben minle. Da bin in) nad) Saule gegangen und babe mir vor

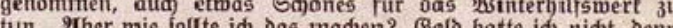
mein meit sater tann mir tein Tajadengelo geb en, weil er nur ein ein

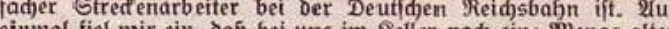

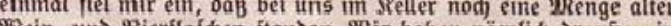

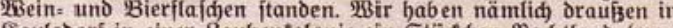
Kaulsoorf in einer Laubentolonie etn Stiddden \$ad)tland (man nennt das "Sdyrebergarten"). Mein Bater batte bort Stadjelbeer. unb Johannisbeerftráudger angepflan3t. Die reifen Beeren wurben ausgeprest und ber Saft in einer groben Rorbflajde zum (Gären aufbewabrt. Daraus wurbe bann fpäter Jobannis= uno

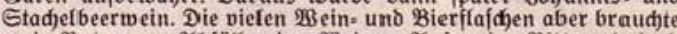
mein Bater zum \&bfüllen Des \$eines. \&uf meine Bitte, mir Dod)

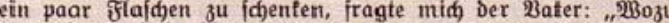
braudfit bu fie? Kas millit bu bertn mit bem Selb? Da

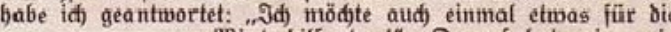
Binterbilfe tun!" Darauf hat mir mein Bater ben Relleridliuffel gegeben uno ban gejagt: „Bir baben swar felber nur menia aber menn wir tönnen, bann wollen mir aud) belfent!" 3wanzig F̂́lajden fdentte mir mein Bater, und id erbielt zmei MRart fün

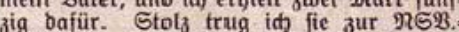
Gtefle uns zablte fie ein. Dic Ouittumg bot mein Bater in feinen Ṡd)rant gelegt, meil

er fid, über midg gefreut hat. "Sieh mal, Junge", hat er zu mir gejagt, den oder 2ilmojen geben ift losialifitid. fondern mit bem Boitsgenofien teilen uno opjern. 2Benn alle beine jungen Rameraben jo benten und banbeln wie bu, bann wirb es bei uns in Deutfdifand balo wieder befier es bei uns in Deutidstano balo wieder befier
merben."
Surt, $\$$.

Id) babe Topflappen genäbt. . . .

\$eil meine Mutter gefagt hat, bas id an Sie fidreiben foll, muß id jest ben Brie fertigmadyen. Denn wir baben für das 23 eih naditsfeft etwas gemadi, und bas foll beim Binterbilfswere abgegeben werben, bamit aú andere eine ơreube baben. Fir fino brei (Bejd)wifter, unb id bin oie Süngite.

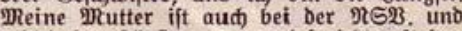
geht in Den f̧äulern rum und fpridist mit ben Leuten. Da fieht fie allerbant, und fie hat uns erzähit, ठаß̧ da mandimal groß̧e Freube it aum uber fieine Sadjen, bie gar nidgt viel wert find. IRandge baben fo mas ju viel und merfen es meg und anbere find arm.

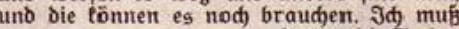

Cine Mtabsentfifutfatic

yat siteintinberauojtattungen

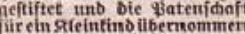

immer bie Sadjen tragert, die meine groke Ed)weiter

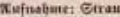




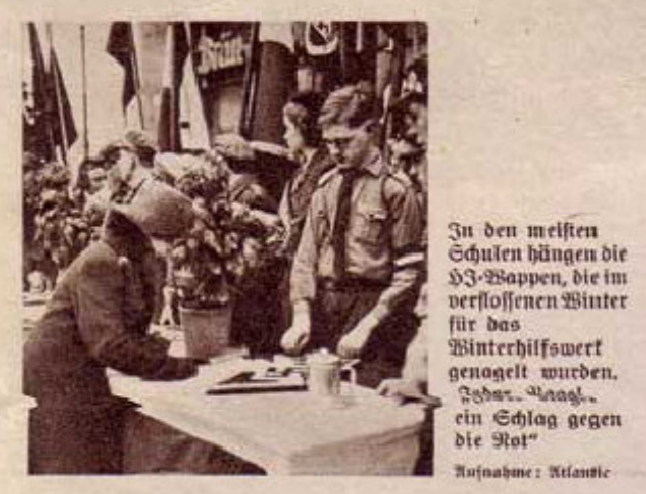

ausgemadjien hat. Meine Mutter madht bie Sachen immer (đ)ön für mid) zuredht, mad)t mir einen neuen fragen ober fo rauf, bamits ein bifichen anders ausfieht. Benn id) Dann zu graß gemorden bin, Dann tönnen mir fie nidht mebr brauden. Orber Da (äbt fid) nod) etras baraus. maden. Da batten wir eine alte Bolljade, bie mollten mir Grinber in Den Rumpenjad fiteden. Dod) Das hat unjere Prut= ter nidht erlaubt. $\$ 2 B i r$ musten bie Jađe aufribbeln. 2Putter hat für fo twas feine Beit, uno bann bat meine Sdbwefter Edjube Daraus geftriat für tleine Stinder, für fo tleine Stinber, bie nod) nidt faufen Pōmnen, die nod) im 2Bagen tiegen, bamit fie nid)t

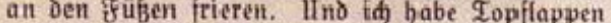
genäbt, meil id nod) nidht ftriden fann. MRuiter hat bie Topilappen zugefonitten und id babe fie Dann mit buntem Barn umftochen. S小 wollte erit jo fleine Maufezäbnchen rumbäteln, aber bas gelang mir nidt. Wuatter fagte, oazu bin id) nod) zu firin, ich foll bis zum näditen Sahr marten uno bié Seute freuen fid) aud fo über meine Topflappen. Ind Dann haben wir es Den andern SimDern in unferm Şauje gefagt, fie follten aud) belfen. Da baben wir Denn aus 2 bfätlen einen ganzen f)aufen Stleinigleiten genäbt, gebäteit unঠ gejtriđt uno jum gBinterbilfsmert gebradt.

PReine Putter bat gefagt, bas müsten alfe Finder fo madjen in Deutidiland und Deswegen [dreibe idh Эbnen. S)eif Sitfer! Stäthe $\mathbb{Q}$.

Die voritehenben Briefe eurer Stameraben und Stamerabinnen zeigen eud, mas andere Rinder für das WBinterhilfswert getan haben. Wie fteht es

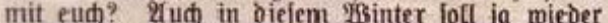
Sumberttaujemben und Miflionen armer 301 ts:

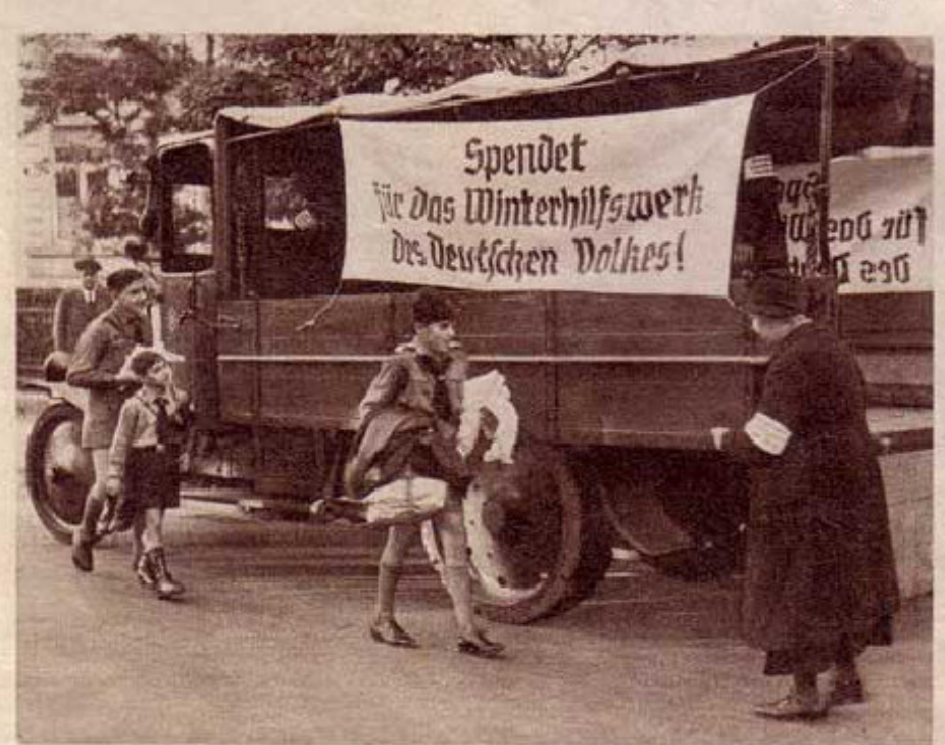

Sungeolt bilft bei ber stieiberfanunlung

Tuinaboue: Tilanth

Muinabene: Etrouk

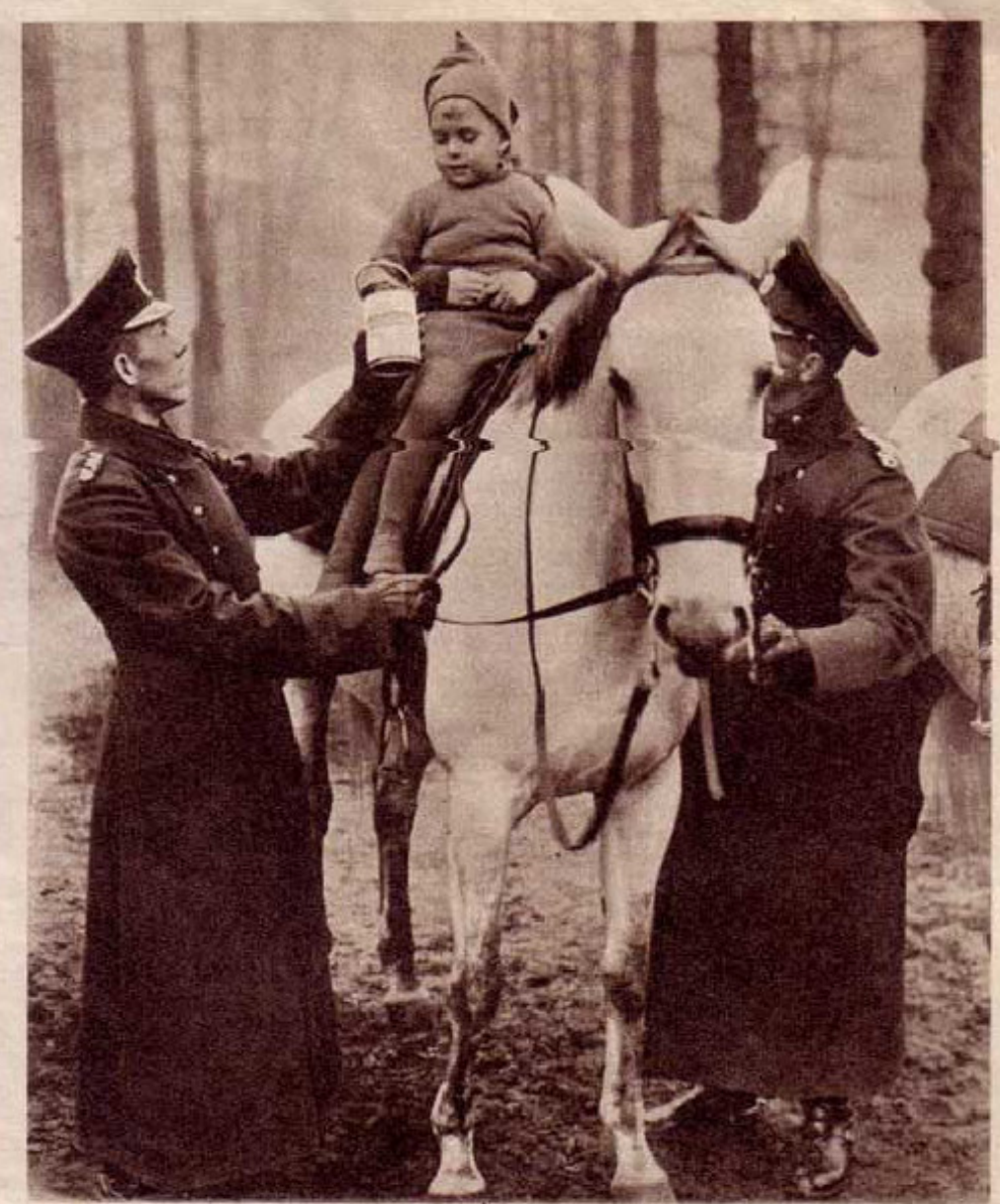

Una Iag Der Folizei

Der fleine 9Ram bat eine Epente in bie Gentmelbihdfe getan und barf baflit auf bem Gdimmel bes qolizeibeanten fiben

genoffen gebolfen merben. Wie molft ihr babei mithelfen? aberlegt eud Dieje

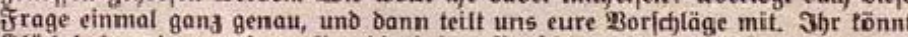
Glüa baben, Denn wir mollen bie beiten Boridläge belohnen. Je nad) ihrem 2 2Bert folfen bafür fünf bis zmanzig Mart gezahlt merben. Mun bentt eud etmas ganz befonderes aus, nidit etmas, mas aile fidon nemadt haben, fondern efmas gan Teues. Das teilt ibr uns bann in einem Briefe mit.

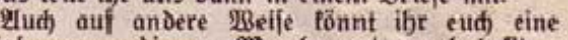
Belobnung verbienen. Dandje unter eud befiben einen Pbotoapparat, vielleidt babt ibr ibn früber in einem, 5ilf - mit 1" - Breisausjoreiben. aewonnen. Der \&eiter bes Minterbilfswertes. Silgenfeld, bittet uns, Die beutidie Jugeno zur Ein= lenoung von Minterbilfsmertbifbern aujaujorbern. In jebem nod) fo fleinen Drt mirb ja in biejem Winter für Das Winterbilfsmert gearbeitet. Der

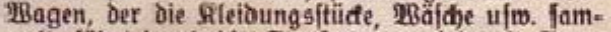
melt fäbrt durd bie Straken, es miro mit Sam: melbüdfen gejammellt uno zu saufe manderlet menäbt uno geftridt. Bemiß merben auch einige Jungen idöne Sadjen bajteln uno zur Eammelftelle des $2 B$ interhilfsmerles tragen; ba gibt's allo eine Menge zu photographieren. Echiat uns bie Bilder ein, bie beften merben ebenfalls mit einem Gelopreis belobnt.

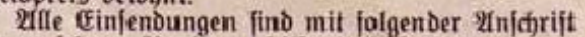

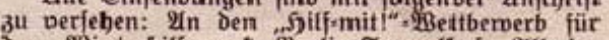
Das Winterbilfsmert, Berlin-Tempelbof, 2ulboinfrafse 21/23. - Der Cinfenbetermin Iauft vom 1. Oftober bis 30 . November 1935. Die beften Por= fdiäge merben veröffentlid)t. Vuf aflen Bufd)riften, aud auf ben Bhotos, mus Bor= and 3uname Des'

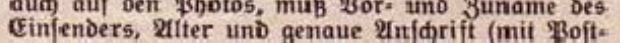
ftation) itehen. Einfenoungen, bie biefe Bedingun:

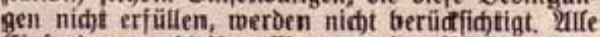
Einfendungen bleiben Eigentum Des Beriages und merben ni ht zurïgejdidt. 
Nós queremos participar (Wir wollen mithelfen), por sua vez, é um texto constituído por três cartas que narram a importância de se contribuir para o programa do governo Brigada de Inverno - e essa coletânea é justamente formada para convidar os leitores a participarem desse mesmo programa. A seção também conta com fotos de crianças e jovens, porém, nenhuma delas está diretamente relacionada às outras cartas transcritas, mas sim a outros projetos de incentivo ao mesmo programa, também da autoria de crianças. A primeira foto apresenta quatro moças manejando roupas de bebês, com a legenda explicativa: "Uma classe de meninas doou enxovais de crianças pequenas e tomou o patrocínio de uma criança. ${ }^{34 " .}$ Novamente, observa-se que a participação de meninas nos programas do governo está ligada a atividades domésticas, como já apontado no texto anterior.

Outras imagens, ao contrário, mostram rapazes entregando panfletos de propaganda política; um menino sobre um cavalo - o que, segundo esclarece a legenda: "No dia da Polícia. O pequeno homem fez uma doação ao cofre e por isso pode sentar-se sobre o cavalo branco do oficial de polícia ${ }^{35 "}$ - e, por fim, a de garotos fazendo doações de roupas para a Brigada de Inverno. Nenhuma das contribuições oferecidas pelos rapazes dizem respeito ao cuidado do lar ou de crianças mais novas.

No que diz respeito ao texto, apesar de as cartas serem assinadas por crianças, a seção em si é de autoria do próprio jornal, o que se evidencia, no último parágrafo do texto, pela forma de se dirigir ao público - "as cartas [...] de seus camaradas mostram a vocês o que outras crianças fizeram $[. .]$.$" - pois o enunciador não se inclui como uma criança.$

As cartas, aqui presentes, de seus camaradas mostram a vocês o que outras crianças fizeram pela Brigada de Inverno. Como vai isso com vocês? Milhões e milhares de compatriotas pobres deverão ser ajudados também neste inverno. Como vocês querem ajudar nisso? Pensem bem nessa pergunta e então compartilhem conosco suas sugestões. Vocês podem ter sorte, porque nós queremos premiar as melhores ideias. Cada um deverá receber de cinco a vinte marcos por sua obra. Agora pensem em algo bastante especial, não algo que todos já tenham feito, mas algo bem inovador. Depois vocês compartilham isso conosco em uma carta. [Grifo nosso] (H3). ${ }^{36}$

\footnotetext{
34 "Eine Mädchenschulklasse hat Kleinkinderausstattungen gestiftet und die Patenschaft für ein Kleinkind übernommen."

35" Am Tag der Polizei. Der kleine Mann hat eine Spende in die Sammelbüchse getan und darf dafür auf dem Schimmel des Polizeibeamten sitzen"

${ }^{36}$ Tradução nossa. No original: "Die vorstehenden Briefe eurer Kameraden und Kameradinnen zeigen euch, was andere Kinder für das Winterhilfswerk getan haben. Wie steht es mit euch? Auch in diesem Winter soll ja wieder hunderttausend und Millionen armer Volksgenossen geholfen werden. Wie wollt ihr dabei mithelfen? Überlegt euch diese Frage einmal ganz genau, und dann teilt uns eure Vorschläge mit. Ihr könnt Glück haben, denn wir wollen die besten Vorschläge belohnen. Je nach ihrem Wert sollen dafür fünf bis zwanzig gezahlt werde'n. Nun denkt euch etwas ganz besonders aus, nicht etwas, was alle schon gemacht haben, sondern etwas ganz Neues. Das teilt ihr uns dann in einem Briefe mit."
} 
No segmento selecionado, podemos observar que o objetivo da publicação e veiculação desses textos em todo o território nacional adquire, além de uma outra autoria, um outro objetivo. O que antes, na fala das crianças, era uma convocação para a colaboração, com o governo - como mencionamos adiante, no próximo parágrafo - torna-se, para os editores, uma propaganda para um concurso, em que é oferecido até mesmo um prêmio - "[...] nós queremos premiar as melhores ideias." - e o principal conceito de avaliação para o concurso não é o ato patriótico em si, mas a criatividade de sua empreitada, pois esperam "algo bem inovador" por parte dos concorrentes.

Porém, no que diz respeito ao objetivo das crianças, observamos uma orientação para o fomento da Brigada de Inverno. O interesse delas não se refere ao resultado de um mero concurso criativo, mas ao orgulho sentido por colaborarem com algo maior que abrange todo o povo alemão. Isso se evidencia na menção à reação que adultos e membros da SS tiveram ao conhecer suas obras, como se observa na referência ao presente recebido - um "quadro do Führer" com a dedicatória 'Aos meus jovens camaradas, por seus serviços à Brigada de Inverno.'; e ao regozijo do pai que, orgulhoso do filho,"pendurou o recibo [da doação à NSV] em seu armário".

No grupo regional do NSV, todos ficaram surpresos e se alegraram enormemente. Agora há um grande quadro do nosso Führer pendurado em nosso lar, que o chefe do Grupo Regional nos presenteou e nele escreveu: 'Aos meus jovens camaradas, por seus serviços à Brigada de Inverno.' [Grifo nosso] (H3 - carta Uma equipe de meninos cata papeis) ${ }^{37}$

Ao pedido de me dar algumas garrafas, meu pai perguntou: "Para que você precisa delas? O que você vai fazer com o dinheiro?" Então, respondi: Eu quero fazer algo pela brigada de inverno". Por conta disso, meu pai me deu a chave do porão e, então, disse: "Nós mesmos temos só um pouco, mas se pudermos, também vamos ajudar!" Meu pai me deu vinte garrafas, e com elas consegui dois marcos e cinquenta. Com orgulho, levei o dinheiro ao posto da NSV e depositei. Meu pai pendurou o recibo em seu armário, pois ele se regozijou comigo. [Grifo nosso] (H3 - carta Garrafa de vinhos para a Brigada de Inverno) ${ }^{38}$

Entendemos, a partir da análise dos excertos, que a negociação nesses textos não é de uma simples reprodução e aceitação da ideologia nazista, mas sim da participação ativa e da

\footnotetext{
${ }^{37}$ Tradução nossa. No original: "Auf der NSV-Ortsgruppe waren alle sehr überrascht und freuten sie riesig. Jetzt hängt in unserem Heim ein großes Bild von unserem Führer, das hat uns der Ortsgruppenleiter geschenkt und dazu geschrieben: "Meine jungen Kamaraden für ihre Winterhilfswerk."

${ }^{38}$ Tradução nossa. No original: "Auf meine Bitte, mir doch ein paar Flaschen schenken, fragte mich der Vater: 'Wozu brauchst du sie? Was willst du denn mit dem Geld?" Da habe ich geantwortet: "Ich möchte auch einmal etwas für die Winterhilfe tun!' Darauf hat mir mein Vater den Kellerschlüssel gegeben und dann gesagt: 'Wir haben zwar selber nur wenig, aber wenn wir können, dann wollen wir auch helfen!' Zwanzig Flaschen schenkte mir mein Vater, und erhielt zwei Mark fünfzig dafür. Stolz trug ich sie zur NSV. Stelle un zahlte sie ein. Die Quittung hat mein Vater in seinen Schrank gelegt, weil er sich über mich gefreut hat."
} 
construção do movimento lado a lado com o restante da nação, ou seja, há um posicionamento de que a ação da criança é tão importante quanto a do adulto, pois os mais velhos também se entusiasmam e os presenteiam por conta de suas atitudes. 


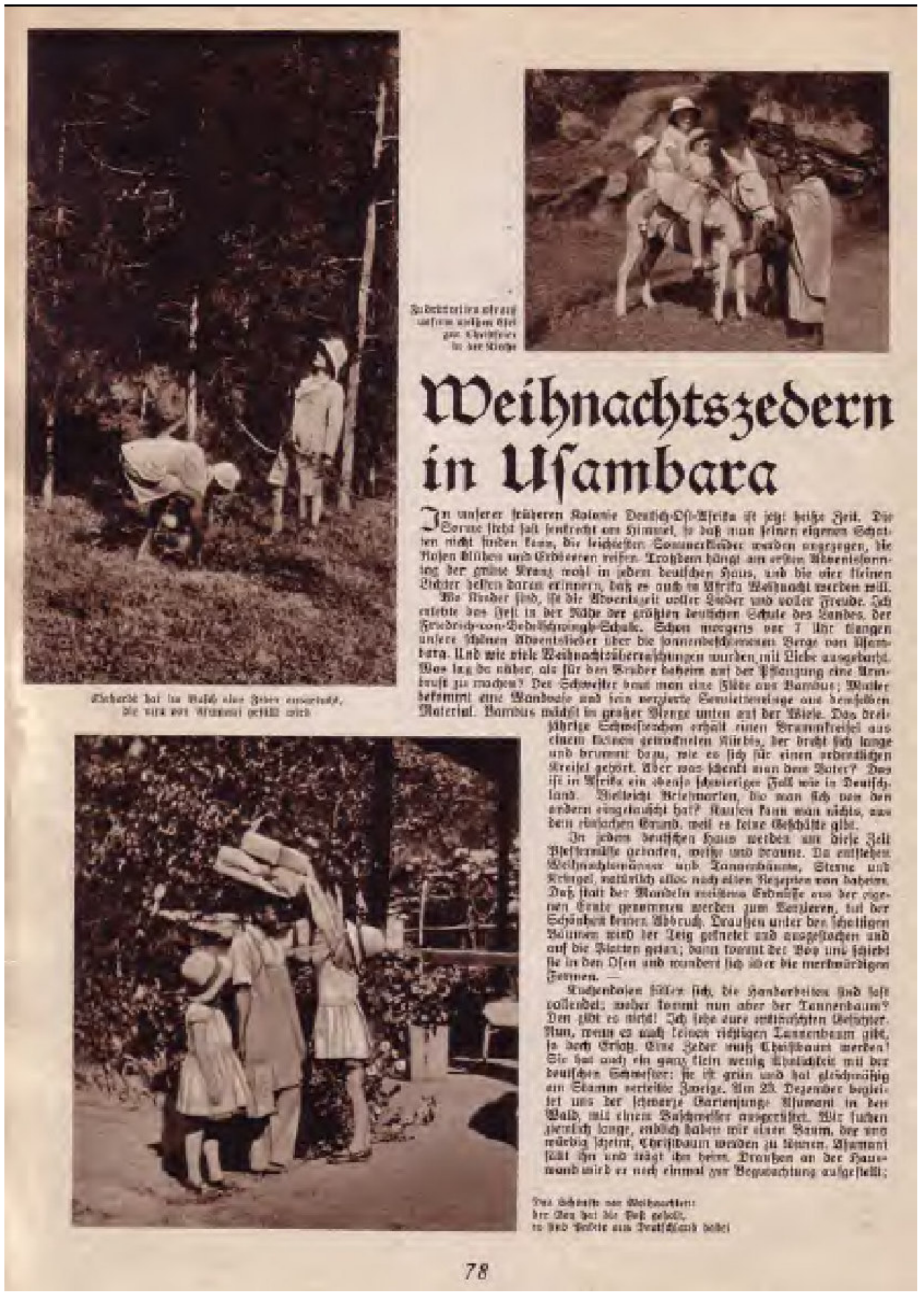

Figura 11: H4, Weihnachtszedern im Usambara, dezembro de 1935, pg.78. 


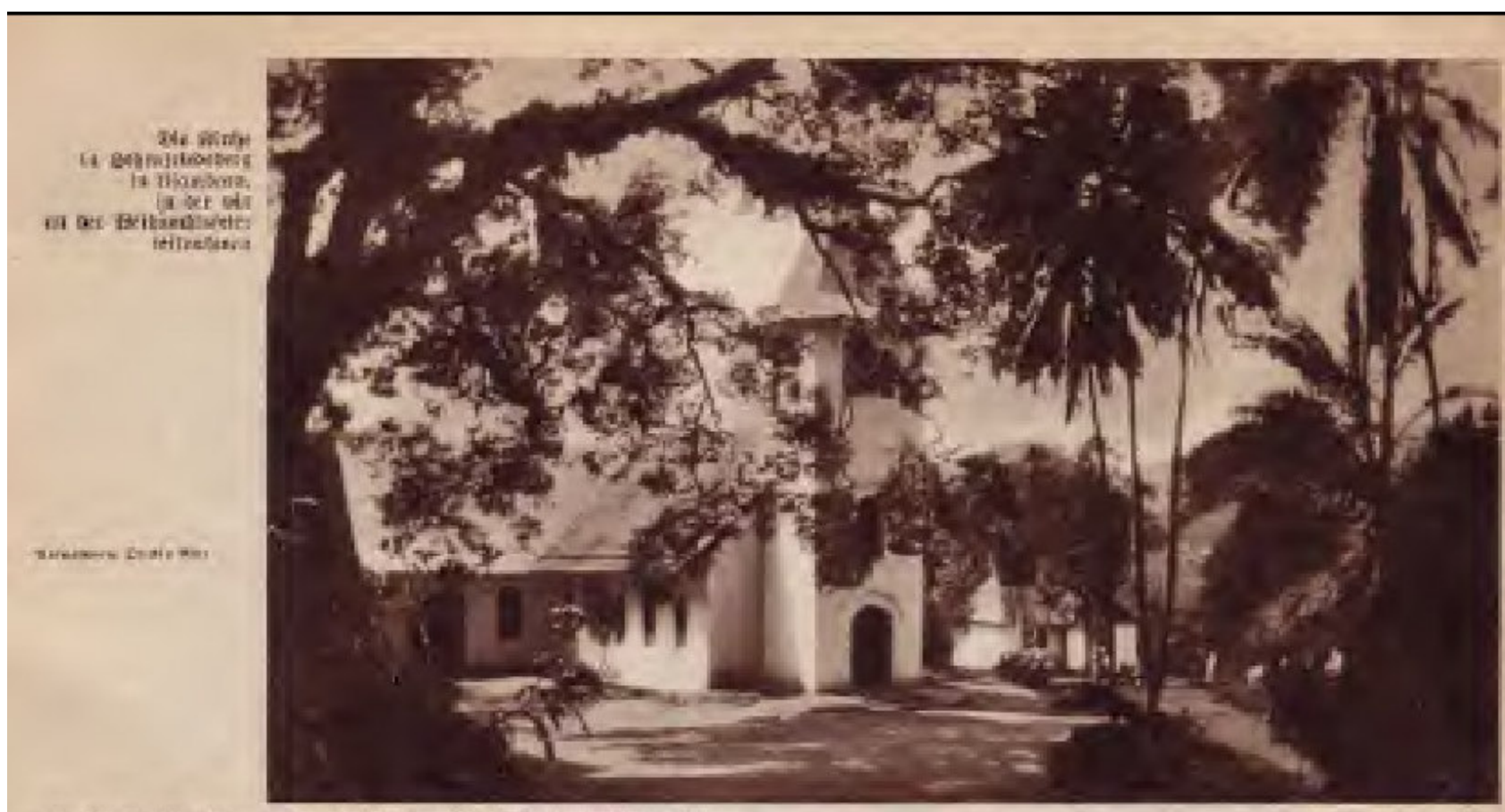

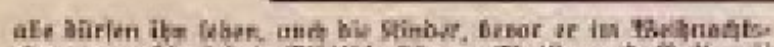

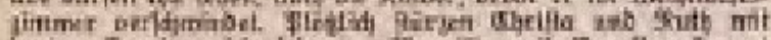

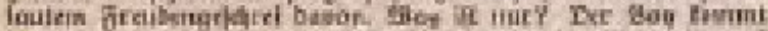

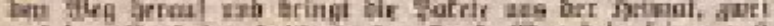

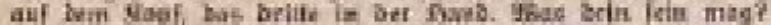

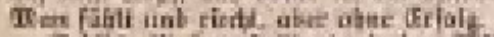

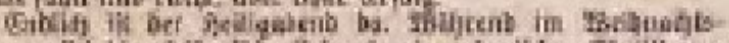

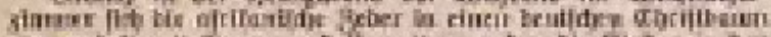

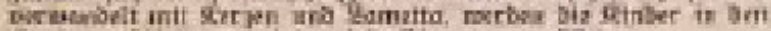

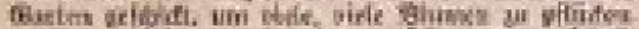

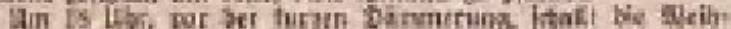

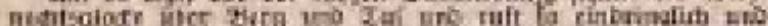

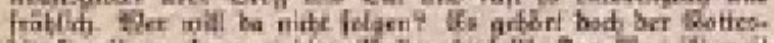

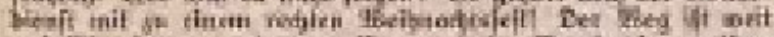

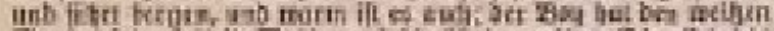

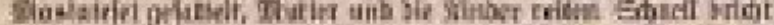

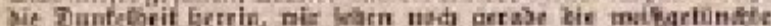

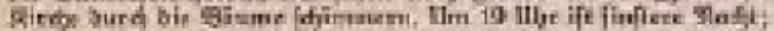

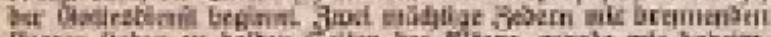

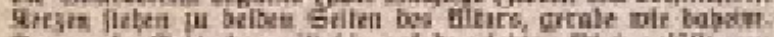

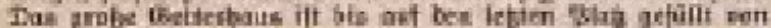

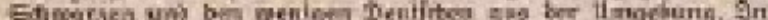

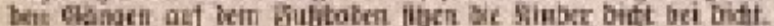

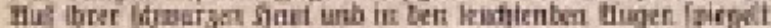

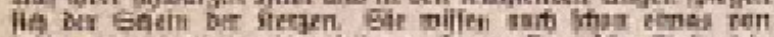

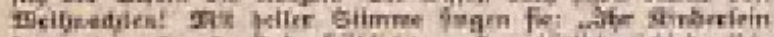

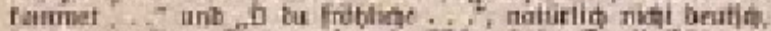

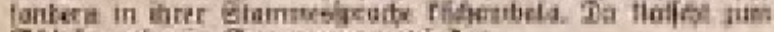

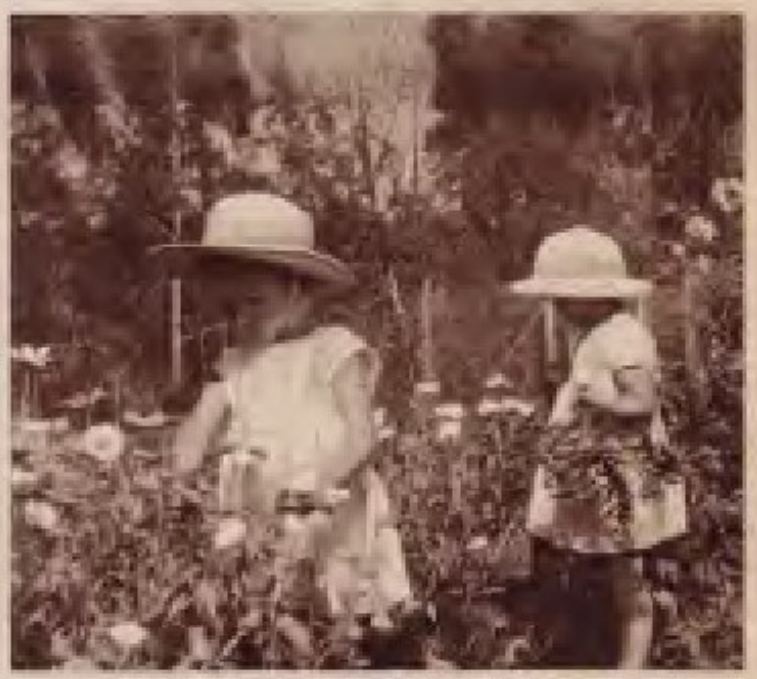

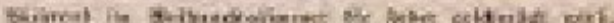

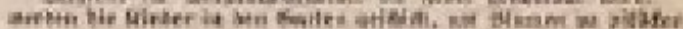

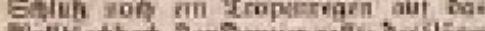

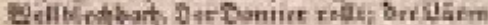

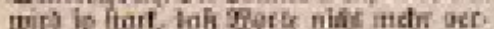

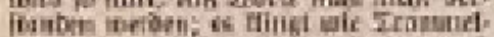

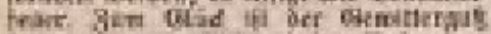

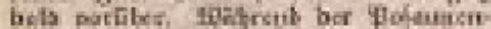

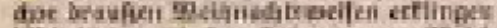

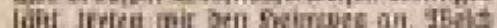

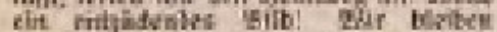
Fhen: bandy bie sunfle Mabit byorger

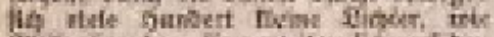

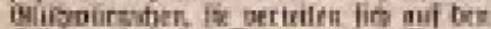

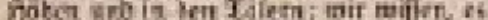

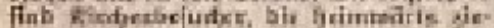
hen mic mit:

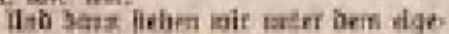

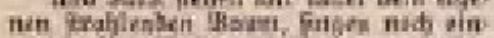
mal unjere Erihantiolicase, poten bis

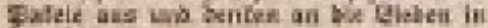
Deititians.

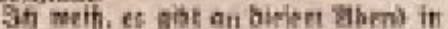

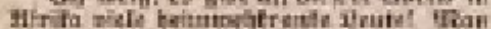

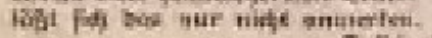

Duibla IIIII.

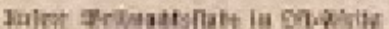

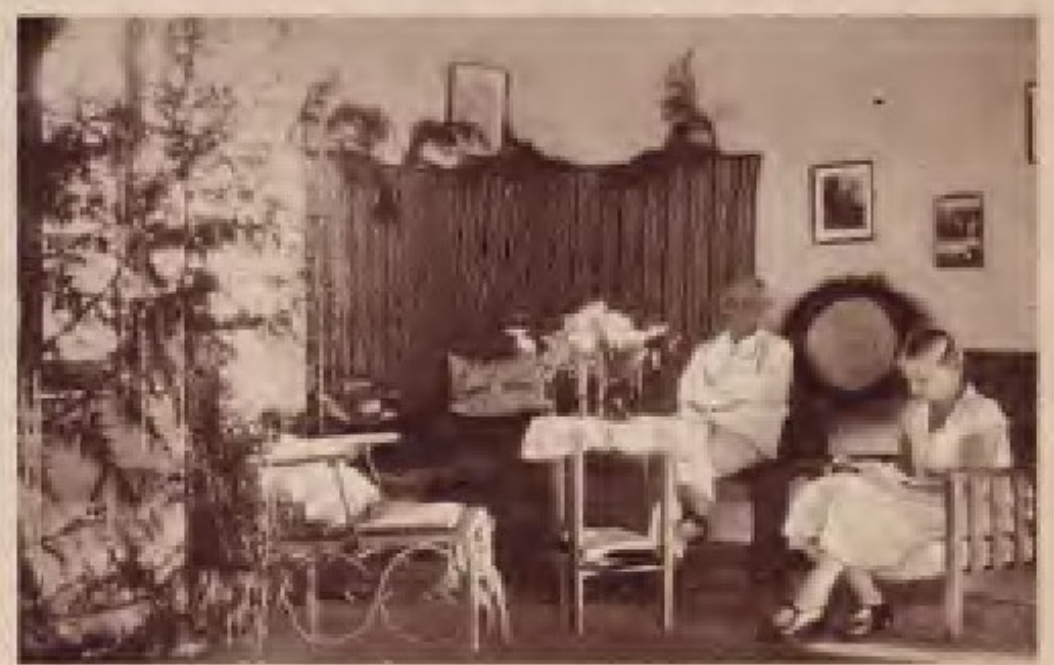


Cedros de Natal em Usambara (Weihnachtszedern in Usambara) veicula imagens de uma família que vive numa colônia alemã na Tanzânia. As três fotos da primeira página estampam as relações de poder de exploração que se estabeleciam no local entre as crianças alemãs e as naturais da região: o rapaz tanzaniano guia o burro que carrega as crianças brancas, corta uma árvore para o menino alemão, e carrega suas malas sobre a cabeça. Já as imagens da página seguinte apresentam elementos próprios da cultura europeia instalados na região, como a igreja cristã, a jovem moça que lê ao lado do avô em sua confortável casa e as crianças que brincam entre as flores, trajando roupas elegantes e chapéus para se protegerem do sol.

O texto é escrito por uma jovem que vivia em Usambara, uma antiga colônia alemã na atual Tanzânia e que, à época da produção do texto, estava sob domínio inglês. Assim como já apontam as imagens, o relato de Ouvidia narra seu cotidiano na região de modo a enaltecer a presença da cultura alemã em detrimento à africana ou inglesa. Seu título se deve à escolha de um cedro como árvore de Natal, para substituir o tradicional pinheiro, inexistente na flora local.

Agora, em nossa antiga colônia teutoafricana oriental, é época de calor. O sol fica quase que verticalmente no céu, de modo que não se pode encontrar a própria sombra, vestem-se as mais leves roupas de verão, as rosas florescem e os morangos ${ }^{39}$ amadurecem. Apesar disso, dependura-se, no primeiro domingo de advento, a guirlanda em cada casa alemã, e as quatro pequenas luzes ajudam a lembrar, que se deseja, também na África, o Natal. [Grifo nosso] $(\mathrm{H} 4)^{40}$.

No trecho destacado, Ouvidia caracteriza todo o espaço como permeado pela cultura natalina alemã, como a menção ao "domingo de advento", à "guirlanda" penduradas nas portas das casas, e às "luzes" de Natal. Ainda que a vegetação e o clima na região sejam muito distintos de sua pátria, - como se destacou: "Agora, em nossa antiga colônia teutoafricana oriental, é época de calor ", "vestem-se as mais leves roupas de verão, as rosas florescem e os morangos amadurecem." - a família da narradora vive como se estivesse de fato na Alemanha. Seu relato evidencia todo um processo de colonização sociocultural. Podemos entender com isso que o objetivo desse texto é afirmar a supremacia da cultura alemã sobre as demais ali presentes.

\footnotetext{
${ }^{39} \mathrm{Na}$ Europa, morango é uma fruta típica do verão e não do inverno, como no Brasil

${ }^{40}$ Tradução nossa. No original: "In unserer frühreren Kolonie Deutsch-Ost-Afrika ist jetzt heiße Zeit. Die Sonne steht fast senkrecht am Himmel, so daß man seinen eigenen Schaten nicht finden kann, die leichtesten Sommerkleider weden angezogen, die rosen blühen und Erdbeeren reifen. Trotzdem hängt am ersten Adventssontag der grüne Kranz wohl in jedem deutschen Haus, und vier kleinen Lichter helfen daran erinnern, $\mathrm{da} ß$ es auch in Afrika Weihnachten werden will."
} 


\subsubsection{Nossos pais fazem brinquedo}

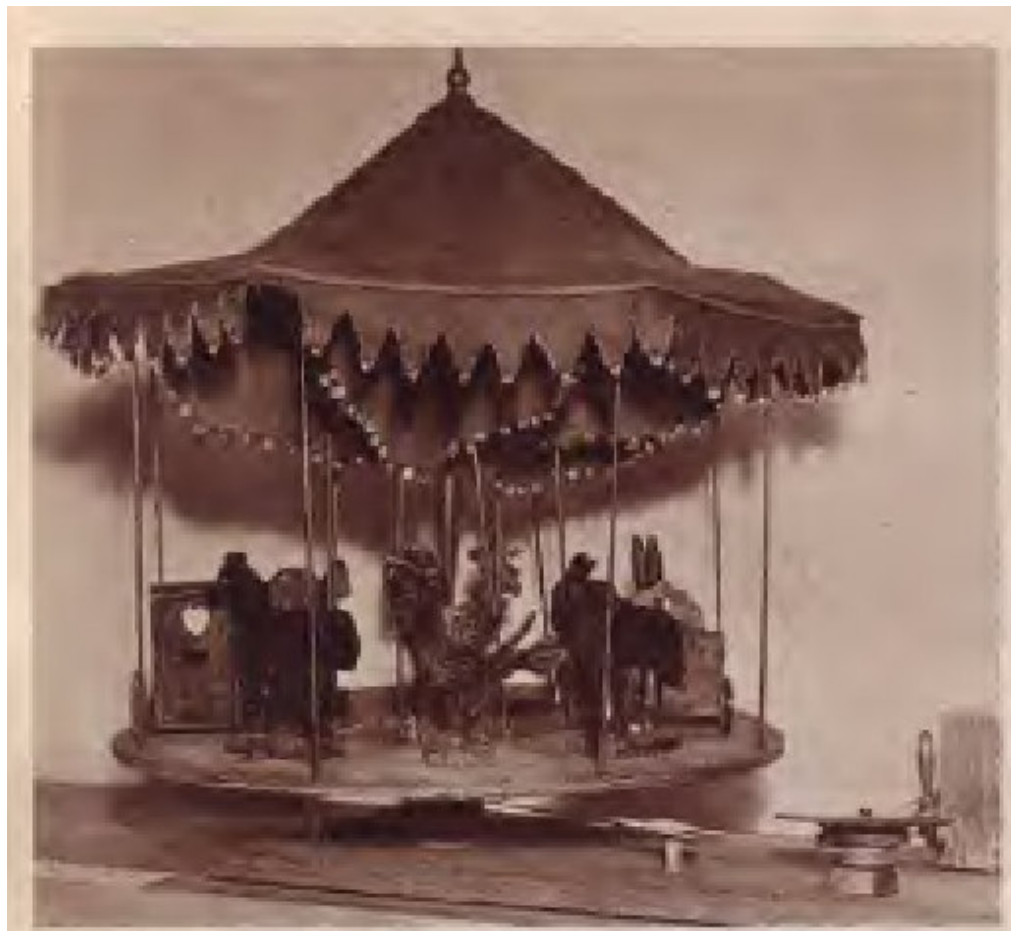

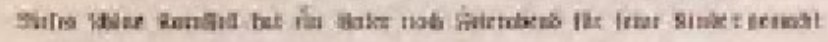

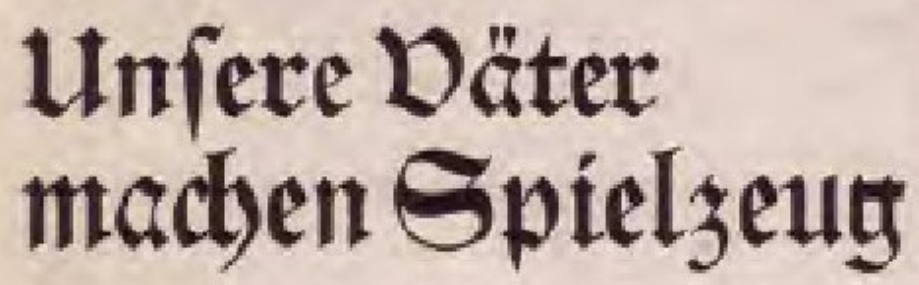

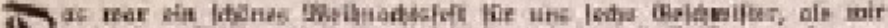

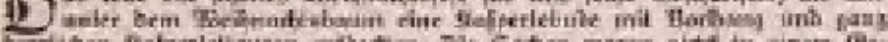

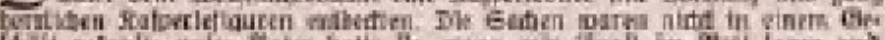

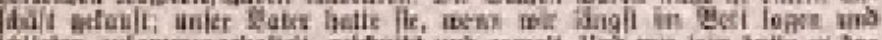

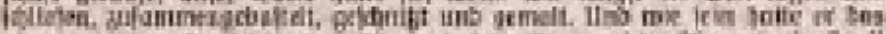

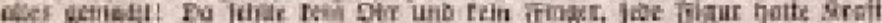

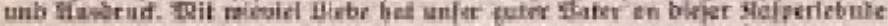

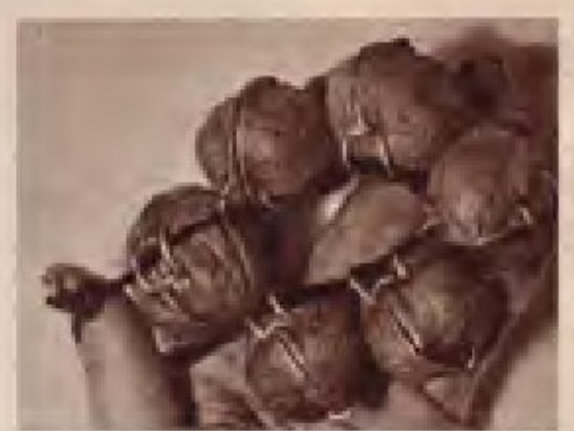

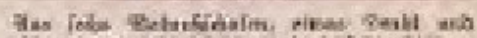

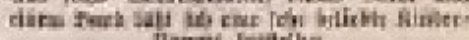
Hawet Fitrilin

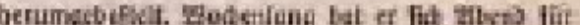

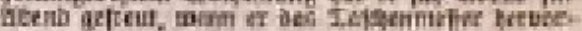

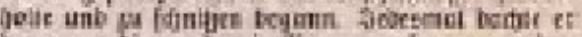

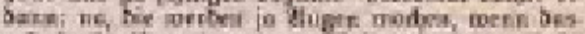

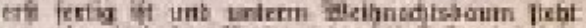

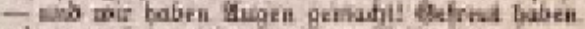
ibit uns raie as frinar ambren Widhnath.

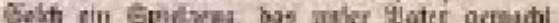

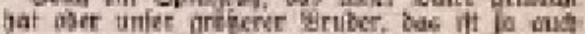

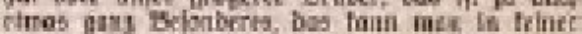

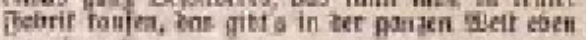
mir cimine!

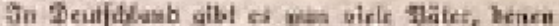

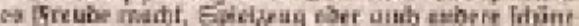

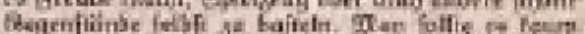

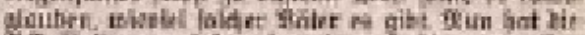

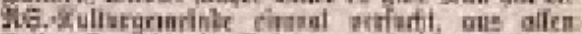

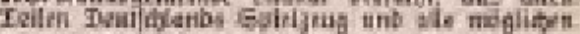

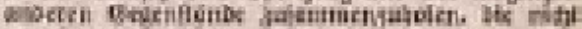

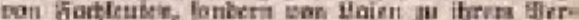

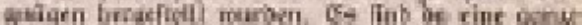

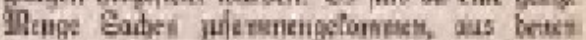

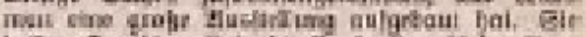

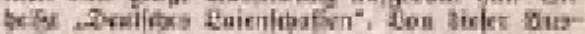

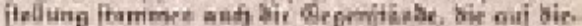

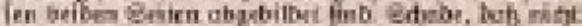

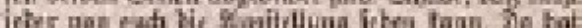

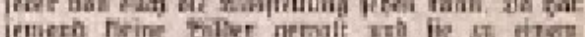

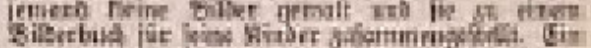

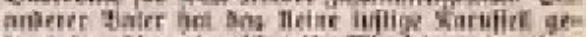

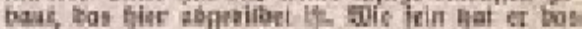

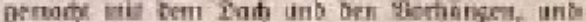

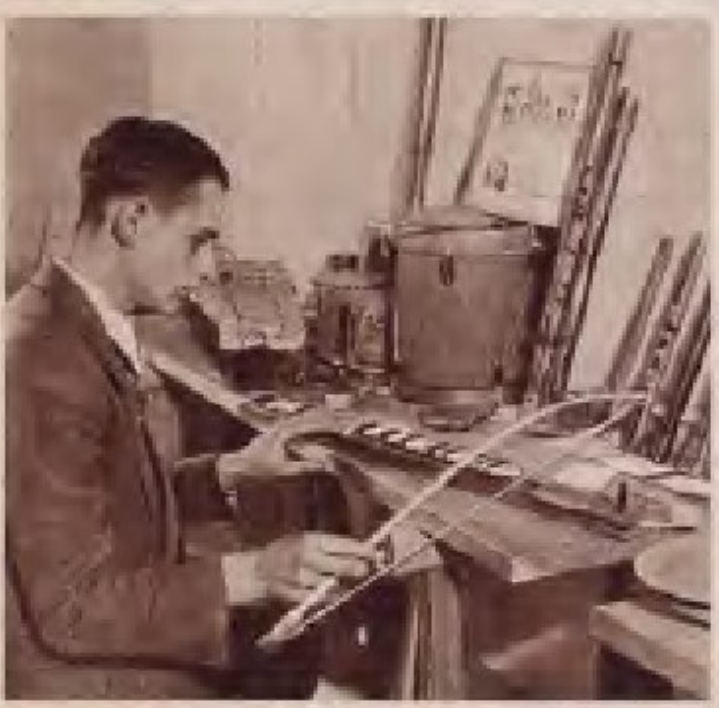

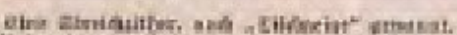

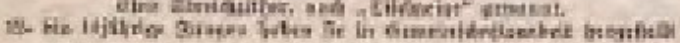

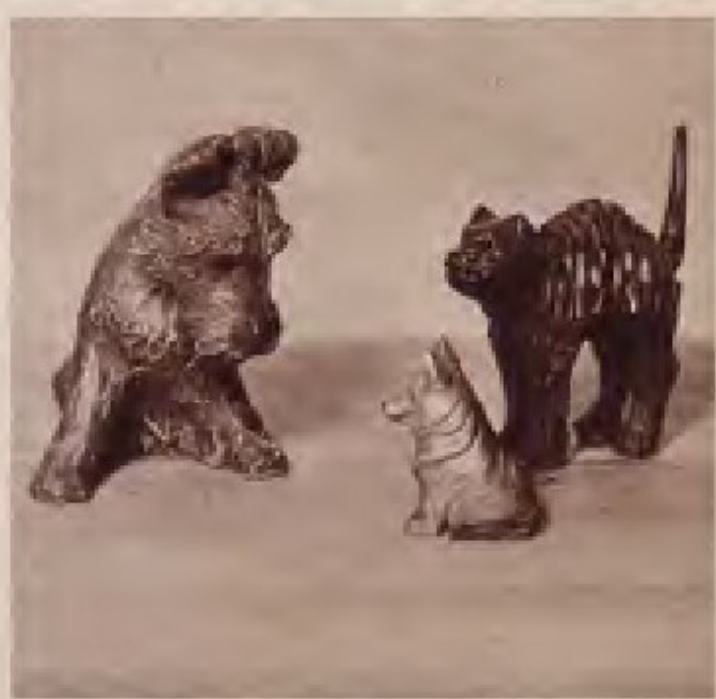

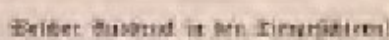

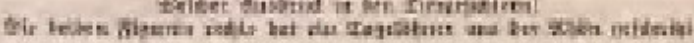




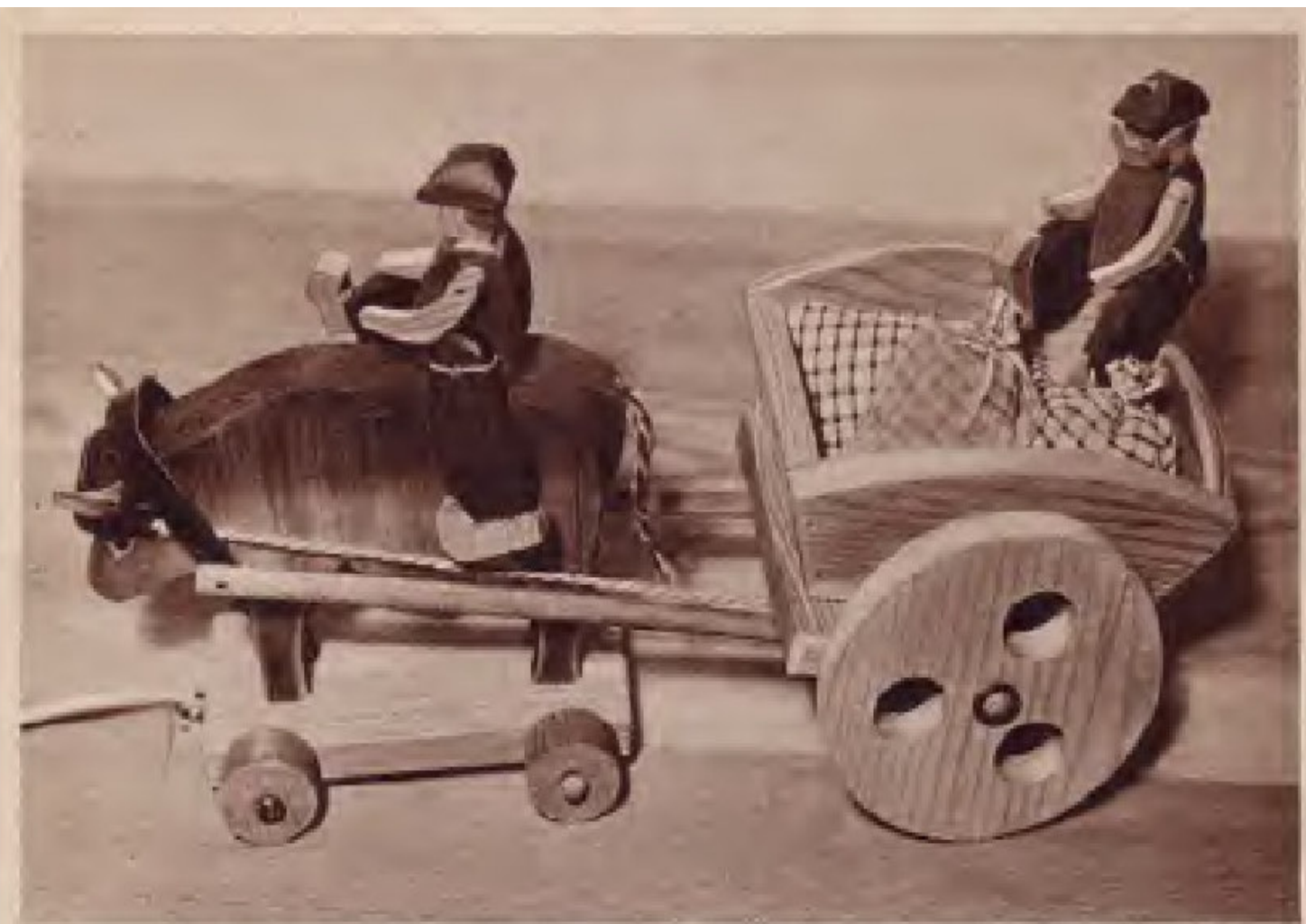

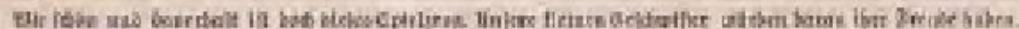

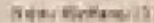

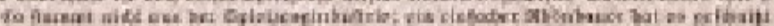

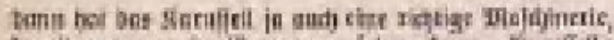

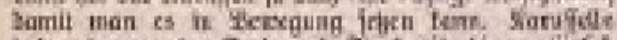

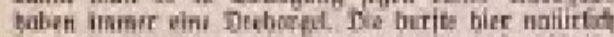

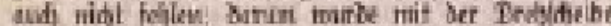

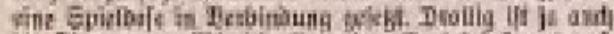

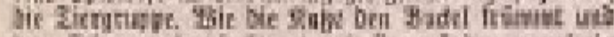

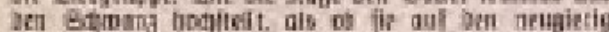

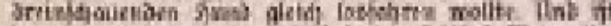

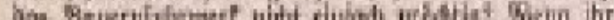

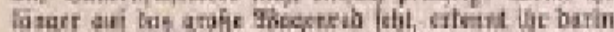

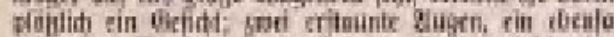

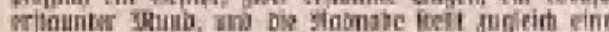

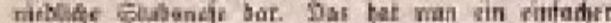

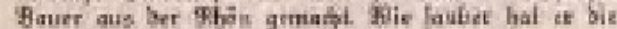

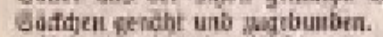

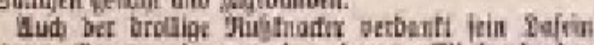

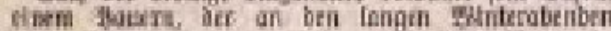

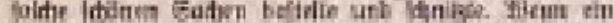

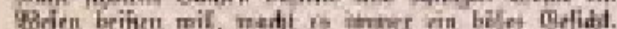

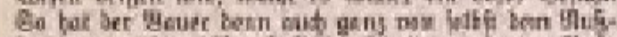

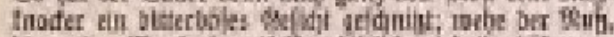

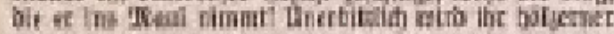

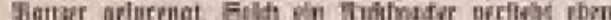

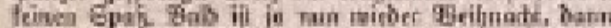

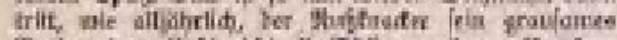

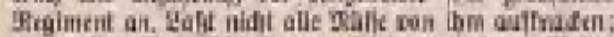

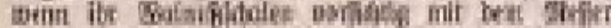

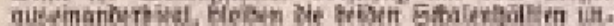

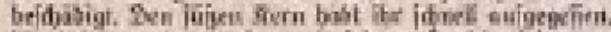

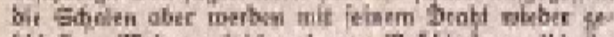

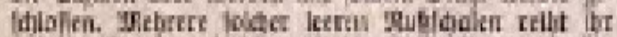

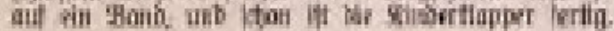

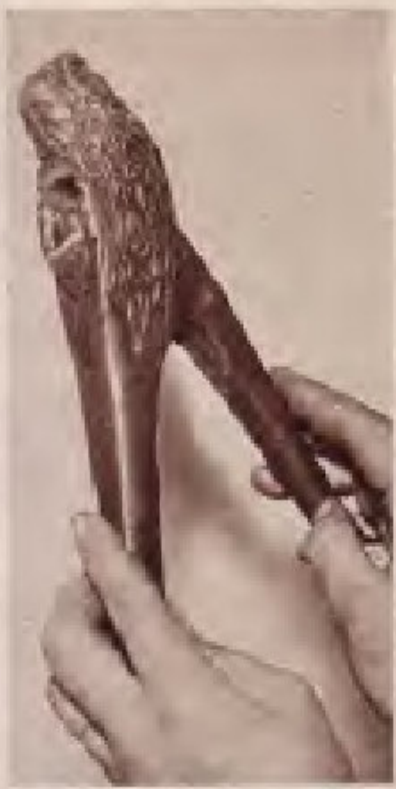

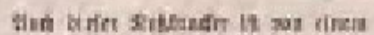

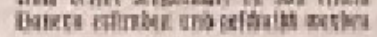

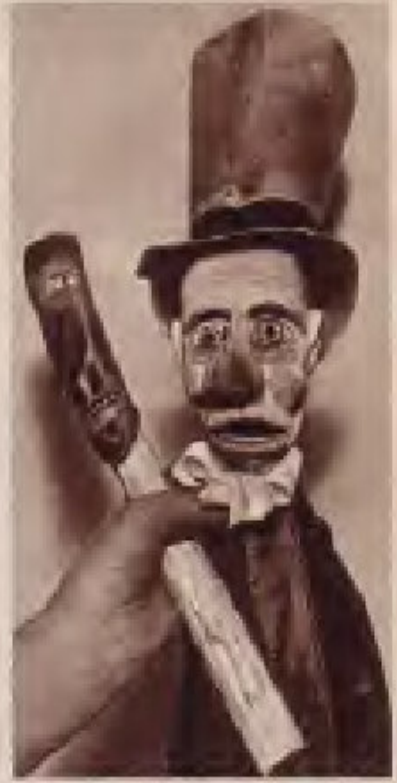

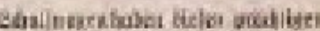
fialestapl ablanity

\section{Dater baftelt}

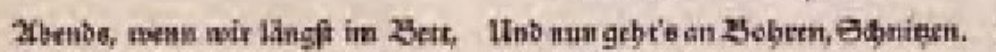

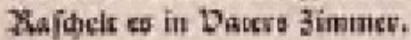

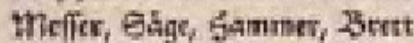
liegen bort in Rantpenf fọimmet.

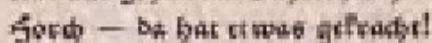
Bhanm mbbt is burd bie Kinger, Wag bet Dare of wobl madst.
Jebes Yabe, fo writ ich bente, wă Belonb'res er rrfanb.

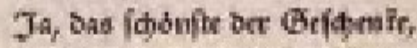

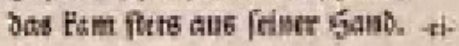


O último texto selecionado do corpus da revista alemã, ao contrário dos demais, não apresenta imagens de crianças. Apenas de brinquedos, ligados de certo modo ao universo infantil, e de um pai que os confeccionava manualmente. Observa-se que nos textos escritos por crianças nessa edição, isto é os dois últimos aqui apresentados, não se voltam para a participação das crianças em programas do governo de Hitler, mas sim a questões propriamente familiares.

Nossos pais fazem brinquedo (Unser Väter machen Spielzeug) conta com o relato de uma criança anônima a respeito dos presentes artesanais que ganhara no Natal anterior. $\mathrm{O}$ fato de tais brinquedos terem sido feitos manualmente por seu pai tornavam a lembrança ainda mais especial, pois, em suas palavras "só há um desse [brinquedo] em todo o mundo.", como ressaltamos no excerto que segue:

[...]Toda vez, ele pensava: É, eles vão se surpreender quando isso [o brinquedo] estiver sob nossa árvore de natal - e nós nos surpreendemos! Nós nos alegramos nesse Natal como em nenhum outro.

Um brinquedo desses, que nosso pai ou nosso irmão mais velho nos fez, é algo muito especial, isso não se pode comprar em nenhuma fábrica, só há um desse em todo o mundo. [Grifo nosso] $(\mathrm{H} 5)^{41}$

O grande valor conferido a esses presentes caseiros, como é sugerido nos segmentos grifados, corresponde a um direcionamento da criança à importância dos laços familiares e da manutenção de tradições; o Natal, festa já bastante tradicional na Alemanha, tornou-se ainda mais especial por conta desse presente: "Nós nos alegramos nesse Natal como em nenhum outro." Essa manutenção e a chamada ao estreitamento do vínculo entre o povo, seja num âmbito familiar, escolar, de grupos juvenis, ou até mesmo fora do território alemão - como em Usambara - , demonstra que, em termos de negociação com seu auditório, há um encaminhamento nesses textos para a partilha de experiências com aqueles que comungam da mesma ideologia que os próprios enunciatários.

Outro objetivo desse texto, é o de divulgar uma exposição de brinquedos construídos por pessoas leigas, também um projeto do governo nazista, como se observa destacado no segmento abaixo, em que o autor lamenta o fato de que nem todos seus pequenos compatriotas terão a oportunidade de conhecer tal exibição:

${ }^{41}$ Tradução nossa. No original: "[...]Jedesmal dachte er dann: na, die werden ja Augen machen, wenn das erst fertig ist und unter den Weihnachtsbaum steht - und wir haben Augen gemacht! Gefreut haben wir uns wie an keiner anderen Weihnachten.

Solch ein Spielzeug, das unser Vater gemacht hat oder unser größerer Bruder, das ist ja auch etwas ganz besonderes, das kann man in keiner Fabrik kaufen, das gibt's in der ganzen Welt eben nur einmal." 
[...] Agora, a Secretaria da Cultura da NS está tentando reunir, em toda a Alemanha, brinquedos e todas outras coisas possíveis, que não foram feitas por especialistas, mas sim por leigos, pelo prazer em produzi-los. Muitas coisas foram enviadas, com as quais foi possível montar uma exposição. Ela se chama "Criações leigas alemãs". [...] Uma pena que nem todos vocês possam visitá-la. [...] (H5) ${ }^{42}$

Além disso, esse texto em especial apresenta uma interessante marca de edição por parte do jornal, isto é, se o discurso foi de fato produzido por uma criança, ele foi editado, uma vez que podemos observar no seguinte trecho, a referência às imagens que foram impressas junto com o texto, explicando em detalhes a exposição de cada foto na edição.

[...] Esses dois objetos impressos nessa página vêm dessa exposição. $[\ldots](\mathrm{H} 5)^{43}$

Não podemos nos esquecer também que o acesso à fotografia era bastante limitado nessa época. Ademais as imagens, que podem ser verificadas na figura da revista, parecem ter sido tiradas por adultos, haja vista o tamanho das mãos que aparecem nas fotos.

\subsubsection{Estrutura e encaminhamento argumentativo em O Tico-Tico Mundano}

Apresentamos a seguir os textos facsimilados ${ }^{44}$ da revista "O Tico-Tico". Lembramos que, o fato de todos apresentarem uma mesma estrutura - uma vez que ocorreram em uma mesma seção da revista, porém em edições diferentes - levou-nos a optar por observar suas estruturas em conjunto, ao contrário do que fizemos com os textos de "Hilf mit!".

\footnotetext{
${ }^{42}$ Tradução nossa. No original: "[...] Nun hat die NS-Kulturgemeinde einmal versucht, aus allen möglichen anderen Gegenstände zusammenzuholen, die nicht von Fachleuten, sondern von Laien zu ihren Vergnügungen hegerstellt wurden. Es sind da eine ganze Menge Sachen zusammengekommen, aus denen man eine große Austellung aufgebaut hat. Sie heißt 'Deutsches Laienschaften' [...] Schade, daß nicht jeder von euch die Austellung sehen kann. [...]"

${ }^{43}$ Tradução nossa. No original: "[...] Von dieser Austellung stammen auch die Gegenstände, die auf diesen beiden Seiten abgebildet sind. [...]"

${ }^{44}$ As imagens disponíveis no site da Hemeroteca digital eram grandes demais para caberem em apenas uma única página, o que compromete a qualidade da visualização e a leitura dos textos. Visando corrigir esse problema, acrescentamos a transcrição de todos os textos de "O Tico-Tico Mundano" nos apêndices desta dissertação.
} 
N 0 G I N B M A,..

- Para fazer um film eontractei as seguintes meuinas e meninos da raa Ja-

sé Bonifacio: Vanda, a loura Constasce Bennett; Yedda, a gracíosa Aniia Page; Lygia, a sympathica Rosita Moreno: Aida, a linda Jeannette Mac Donald; Mrarietinha, a ingenua Sylvia Sydney; Valma, a alegre Clara Bow; Maria Seli, a fascinante Norma Shearer; Rachel, a inesquecivel Pachel Torres; Georgina, a adoravel Joan Crawford; Jorge a noseo querido patricio Raul Roulien; Fernando, o gesial John Barrymore; Henriquinho, o romantic Ramon Novarro; Walter. b engraçado Buster Keaton; Luiz, o nthleta Philippe Holmes; Úrbaae, o sympathice John Gilbert; Alberto, o formidavel Etam Laurell, e eu a directora - I. C. $B$.

- Para organizar um film em Magé, contractei os seguintes amiguinhos magéenses:

Carmelia, a deslumbrante Shirley Grey; Luiz, o Heinz Rtühman; Zeliă, a interessante Frances Dee; Jorge, o conquistador John Gilbert; Ondina, a galante Diana Wyniard; Maria S., a Claudette Colbert; Benjamin, Herbert Marshall; Glorinha A., a linda Joan Crawford; Noemia, a sympathiea Verna Inie; Maria Elisa, a eneantadora Lona André; Lourdes As. kumpexáo, a irresistivel Leila Hyams; Cesar, o' terrivel Monte Blue; David, - aventureiro Buck Jones; Alcina B., a graciosa 'Zazu' Pits; Almir; 0 elégante Richard Arlen; Eulalia P., a Sylvia Sidney, a sylvia Sidney, Ateracip Satier.

n. L e vantout ฟéo de regresso ao Brasil, o aviāo Sí. vis, trazendo um casal de astros que vieran in terpre. tar um film. Eram tar um film, Eram elles: Antonio S.
da Cunha, o Dourglas Fairbanks e a Maria Lelis, a Joan Crawford. Na Joan Crawiol. Nam travessia triveram de enfrentar os ros: Liliana, a chuva; Justino, o relampago; N'e I. relampago: trove:

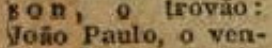
Joúo Paulo, o venratinnte, C a r los, b sol. Sem mais fembaraces, enconira r ran - se com Ir a r con -se com
Humberto, o dia; Dula; a noile: segaida de Ruth, a laa; Olavo, o PluIÍ⿴囗十 Nitria, a Ve: nes; Nilza, a Jupiler, - Florinda, a Sirrus. Depois de passarem o arcoiris, Roberto; chegaram salvos no

\section{A distribuiçélo dos premios do Grande Concurso da Independencia}

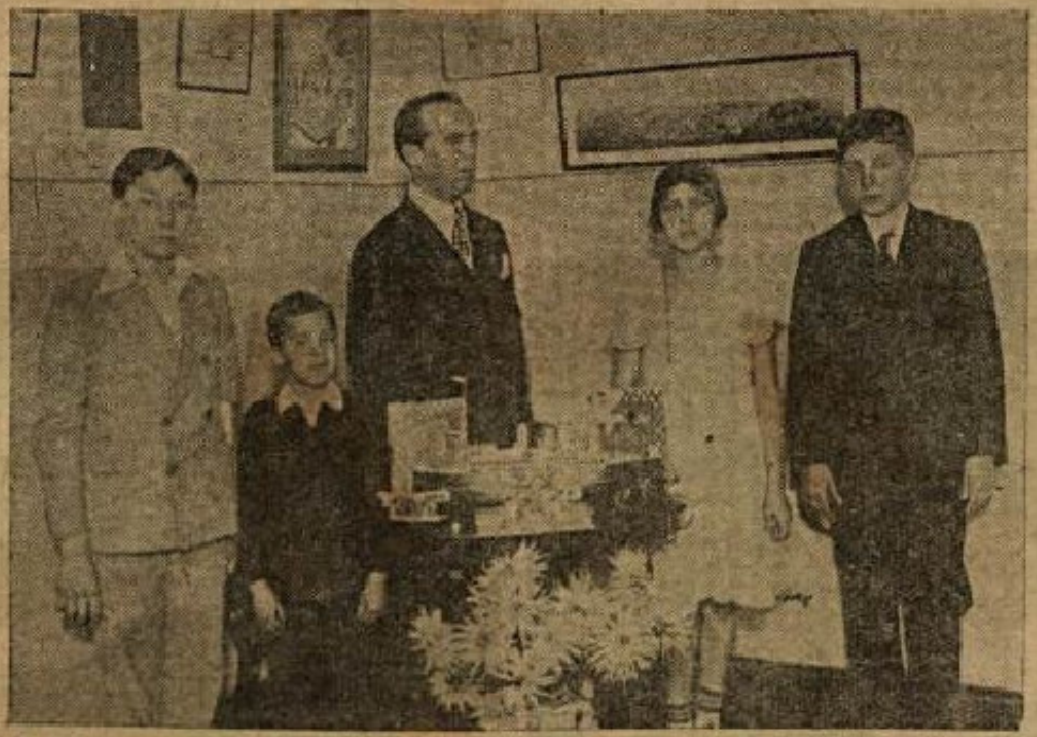

A photogreyhía acfima foi tirada na succursal, do TiCO-TKCO, em Sâo Panlo, quando all se procedía d entrega dos premios do Grande concarso da Independeneía aos contemplados no importante eertamen. Os premíalos foram os seguintes leito res: Haroldo Graner, $3^{\circ}$ premio: Pas-

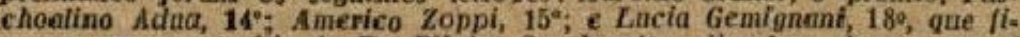
quram em companhila do Dr. Plinio Cavalcante, director da succursol do TICO-TICO.
Campo dos Affonsos, onde os esperavam os seguintes astros: Nair, a Norma Shearer; Elsa F, a Kay Minna Gambel; Carlos, 。 Tom Mix: Irabel, a Constance Bennett: Gabriei,

$\therefore$ Querendo offertar á nossa profesora de traballos am ra1:10 de bellas flores, escolhi as se-

Carlotai, uma vistosa sempre-viva: Zulmira, uma mimosa flox fle sêra; uma delicado Myosotis; Madina, chrysanthemo; Alberto $\mathrm{S}$, um bello boso manacá; Maria de Lourdes. uma triste violeta: Paulo, um bonito alfincte $\mathrm{e}$ or de rosa; Mka, uma apreciavel cravina; José $\mathrm{B}_{1}$, um encantador jaemim, e eu, um beijo de N $A$ G $A$ I 0 L L A ...

- Estấo na gaiola os seguintes aluminos

Aurea, uma araponga; Alvaro, um papagaio; Damiáo, um corio; Carmita, uma sabiai; Lourdes, uma cigarra; Zexé, um canario; Antonio. um chorăo; Zeferino, um pien-pảu; Lourdes V., um bico de lacre; Ernesto, um vira-bosta; Antonio P., um pardal; Vêra, u ma andorinha: Dúra, um avinhado; Sebastiẫe, um gallo da serra; Belmira, uma lavadeira: Chico. um periquito; Pedro, um colleiro: Virgiaia, um gaturamo; Alice, uma patativa; Elza, uma maitaca; Alfredo, um chẩmchâo: $\mathrm{M}^{2}$. Angusta, uma graúna, e eu, por ser o dono dos passaros.

EM LEIL

- Estấo em Teilă as segeaintes senhoritas e rapazes residentes no Meyer:

Quanto dẫo: pelà altura da Alda? pelo sorriso da Dilma? pela bondade da Cremilda 2 pelos modos dat Joanninlas? pela tristeza da Lourdes? pela elegancia da Jújú? pela sympatbia da F $\mathrm{F}$ a n cisquinha? e quanto dlío pela querida Leiloeira?

Compre livro - "HISTORIAS DE P. AE J OA O " Preço 5\$000. Figura 15: T1, O Tico-Tico Mundano, Ed. 1475, janeiro de1934, pg. 25. 


\section{A NNTVEHSAHIOS}

at is Festejou a 5 deste mez a passagem de sun data nattalicia a etraciosa Ma-

ria Lueia, Thinha do Dr. Pablo Etrivelio e nossa assiginante.

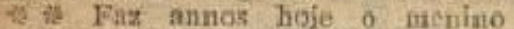

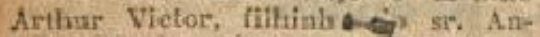
tonio Pereira Lima e nosso presado amiguinho,

as $\approx$ Faz amnos hoje o nienitio Constantino, filho do capitẩo Lauro cle I.ima,

A2 Passou hontem a data nataHeia da menina Elza, filbinha do nasso collega de imprensa Mauta L.oureiro.

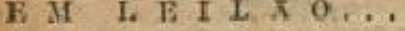

12 * Leilia dos repazes e mogas ate Realengo:

Ounato me diro pelos Iabios de Chiquinho? pela delieadeza de Chiquito? pelo formidavel corpo de Chaquihe? pela bondade de Rogerio? pelo sorriso de José? pelos cabellos se Nónốz pelo andar de Maria da Gioria pelas faces de Gillbertina? pelos olhos de Ixa pelos pés de Iritcema? pelas risadas de Zalma? pelos aborrecimentos de Bijaga? pelo perfil de Luiz $\mathrm{M}$, N.? pela fineza de Honorio? pela applicacāo da Selva?

Lefloeira Flor de Amor- ReaJengo.

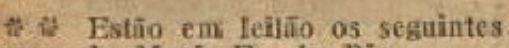
Jovens de Magé, B. da Rio.

Quanta dẫo: pela "pose" da Eunice I. 2 pelas risadas da Elisabeth? pelo gracioso andar do $\mathrm{Dr}$, Claudio? peha altura-da Nair I.? pelas excarsóes do Gustavo? pelos modos da Tosita? pelos desprostos do João F.? pelo moreno da Ontina? pelo ollasy do Orlando? pela simplicidade da Celia? pelo retraimento da Flaviniat? pelas Bracinhas do Jota J,? pelo sorriso da Lubelia? pelas telephonemas do Jello Cunha? E quanto dâo bela lingua da leiloeira?

* * Estão em leilão as seguintes meninas e mentinos do bairro do Rio Comprido:

Quanto dằo: pela "pose" da Eanipelos modos de falar da Jacyrema? pela sordura da Lina? pela pacien-

\section{B $\&-\mathbb{b} \& \&$}

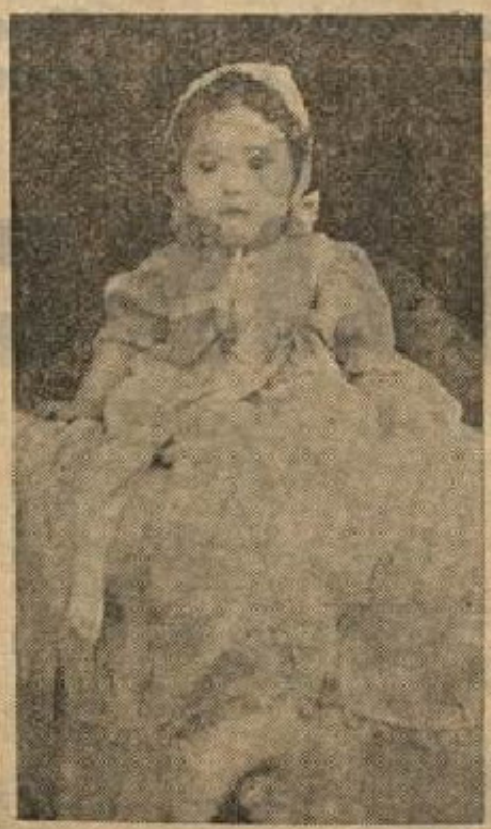

Therezinha, Itirda filhinha do sr. Herminio Pinheiro

cia do Alvaro? pelos carinhos do Mario? pela belleza do Antonio? pelas pernas do Jorge? pela bondade da Nitza? pelas corridinhas da L.tzette? pela educaça do Aurelio? pelo sorriso do Délphim? pela cór morema da flosa? pelo sorriso da Lydia? pela sympathia da Adelaide? pelos eabellos da Yolaudat pela timídez da Ignacia? pela e ô r dos ollhos da Marina? pela esperteza da Linda? pelo nariz da Aurea?

N 0 G I N E M A . .

ab oterento organizar umi ftlm, contractei as seguintes senhoritas e rapares do bairro de Olaria: Nair, a linda Rosita Moteno; Isaira, a meiga Jeanelté Gaynor; Lourdes, a morena Katho Von Naty; Aurea, a sedaclora Dolos res del Fio: M. Antonia, a engracate d.t Vivian Duncan; Irene, a formidavel Cecilia Parker; Léa, a Rosetto Duncan; Marla Magdalena M., a bonltinha Jeanetle Mac Donald; Aurelio, como George O'Brien; Sanl, Tom Tyler: Newton, Raman Novarro; Jayme, C.. Charles Farrell; Frederico March, Celio, M., Ary, José Mogica; Amaro, Adotio Menjoa; Pedrinho, Bem Lyon; Nelson C., Gary: Mario, Raul Rons lien: Irany. Rieardo Dix; Oswaldo, William Haynes.

\section{N $\alpha$ J A R D I M ...}

불 광 Querendo offerecer uma $\cos ^{2}$ belle, ao querido amiguinho José Ries, escolhi as seguintes flores de $4^{\circ}$ anno B, do Grupo Escolar Pedro Varella:

Yara, uma vermelha papoula; José Lellis, um simples myosotis; Lydia, uma graciosa hortencia; Raul, um elarysanthemo: Edith, uma rosa rubra: Ivo, nm lyrio: Selma, uma lindy bonina; Hilda, una candida angeli$\mathrm{ca}$; Nadir, uma palifla magnelia Zelia, uma glycinia; Nair, a cesta; Alvaro, a fita, e cu amor perfeito. Princeza do Pate das Maravilhes (Adriana Oliveira).

SECG $\triangle O$ DA DOCEIRA...

* * Ouerendo offerecer um holo a distincta e querida professora D. Yolanda C. Pinheiro da Cunha, fiz o bolo com o segruinte: 250 grams, dos cabellos da Wanda, 100 grms. da dentadura do Raphael, 150 gruns, da fordura da Belmira, 100 grms. da elegancia da Esther,200 grms, das ondas da Alayde, 100 grms. das risadas da Zneide, 200 grms, da linda eabellelra da Etelvina, 250 grms do cheleirismo da Maria João.

Escove os seus dentes de mashă, a noite e após as ref́eiçóes. Escoveos, pelo menos, de manhis, ao meio dia e á noite.

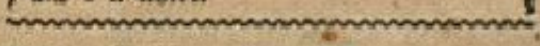

\section{NOSSOS GALANTES LEITORES E AMIGUINHIOS}

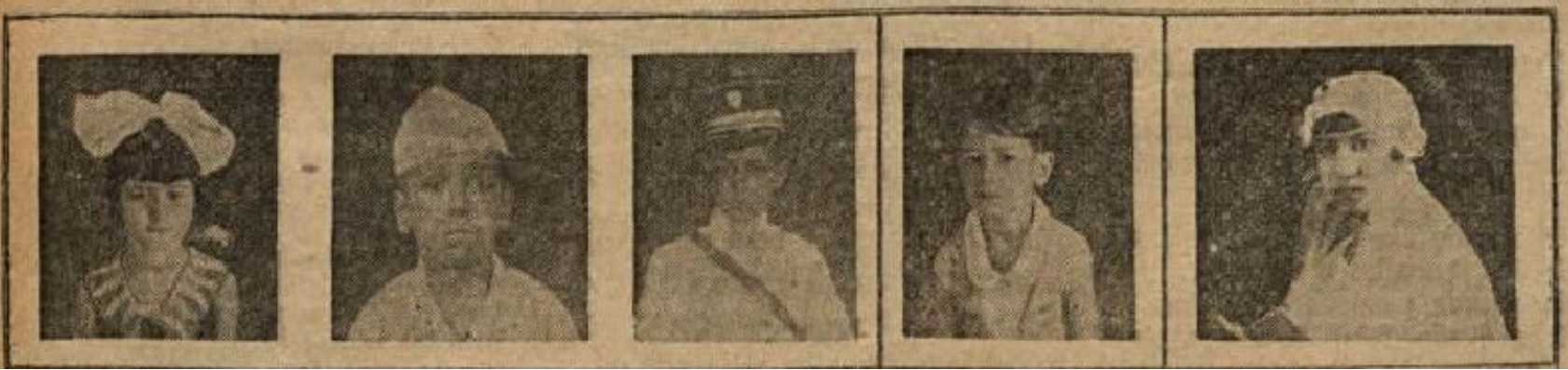

Figura 16: T2, O Tico-Tico Mundano, Ed. 1480, fevereiro de1934, pg.6. 


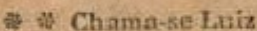

( TICO.TICO MUNDANO

belleza do Walter Curvello, 50 grs. do genio da Gilberlina S. Paulo, 500 grs. da elegancia da Onofricito no dia 3 deste mez o tilho do easal

Dr. Ieonardo Pereira - D. OIga Lemós Pereira.

2. 5) Recebeu a nome die Bulec a Hinda meniaa, filhinha do casal Diogenes de Brito - Dila Castro Brito.

Dntce naséceu the dia 2 deste mez.

A N NIVERSARIOS

* * Faz annos hoje o menino Genaro, fitho do sr. Adtherbal Notneira Aives e nosso presadio amiguinho.

* o Maturita, galante filhinha do sr. Mauro Pacheco, viu passar sahbado ultimo a data de seu annivercarto natalicio.

* * 0 nosso amiguinho Jayme Figueiredlo festeja hoje a sua data natalicia.

to st Maria Celía, nossa amigatsha, fithinha do sr. Franeisen Velea, festejou hontem a data de seut natalicio.

\section{Y 1 S I T A S}

Fsteve en visita à nossa redacção - estudioso Daniel Israel, nesso precado vestor residente en Porto Alezre e ara em excursấo nesta Capital.

\section{E $M$ L B I I $\mathbb{A} \quad 0 \ldots$}

* *ี Estīo em leilāo os seguinites fovens de Corumbá - Matto Grosso:

Quanto dẫo: pelos ollios da Ėlisa Femañ pela dansa do Rodolpho Boe. ca? pela risada da Sonia Sivvira? pelo andar do Nequinho de Barros? pelo desembaraco da Maninla de Barnos? pela pose do Jarge Percira? pela altura da Cella Vax? pela sympathin do Virgtilo Gondim? pela cabelleira da Direa Bastas? pela eleGancia do Clio Proenca? pelos eilios da Dora Gomes da Silva? pelo chi quismo do Alexandre Mozzile? pela paleatra dn Neide Diette Amamin paleatra da Neide Odette Amarali dentadura da Cleusa Proencen? pela extatura do Nino de Bareos? pelns mracpis da Miracy Soares Peres? pela risada do Cia Wanderiey? pela voz da Divina do Coulo? pela elextancia do Lniz Fontes? pelia inteliseneia da Lennarda Esteves de Lacerda? pelo sorriso do Clovis Vasquez? pelo lonro ala Dalila S. Pedteo? nela gran ca do Aleides Marinho? F finalmenfe. quanto dấo pelas leitoeiras do Alheis?

* * Tendo occasiāo de ir buna tarcle no Fomenho Novo, rseolvi to-

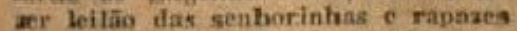
qư frequentan assiduamentio essa alerse estaciño.

Ouanto däo pelo korriso do Titaz pela honestiatarie the Pmalo? pola pela donestiniade the Pmilo? pois

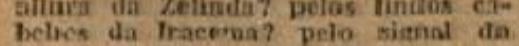
Celia? pela graca do Orlinito? pera finura da Trene? pelo biqodinbo all. whato do Helio? pela belleza stes ers.

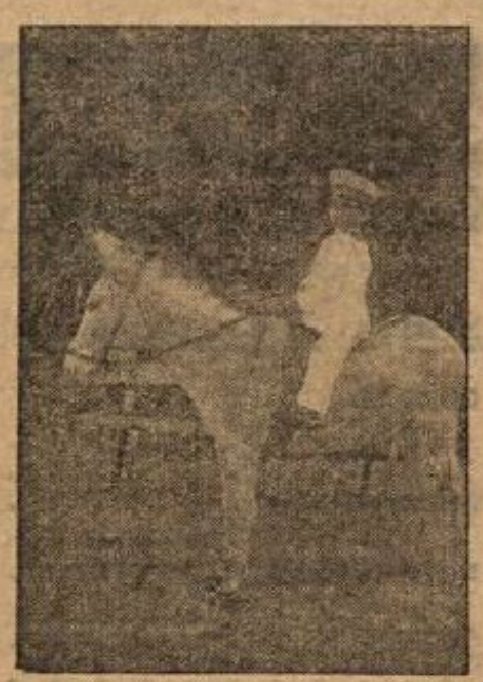

o nosso presado amífuintho Helto Conto, que vín passar a sua festo de anniversario a 2 deste mez.

bellos louros de Yvoune? pela elegancia ifa Maria? pela voz sympathiea da Cacilda?

\section{SECCAO DA DOCEIAA..}

* * Para offereicer um bolo ao Banga' Foot-Batl Clnb, escolhi os seguintes ingredientes:

100 grms, do cabeilo alotrato da Eumice Ofrede, 25 grs. dos olhos da Zulma F. Brigder, 50 grs. da dentadura dir Iracema Braga, y/2 kilo da

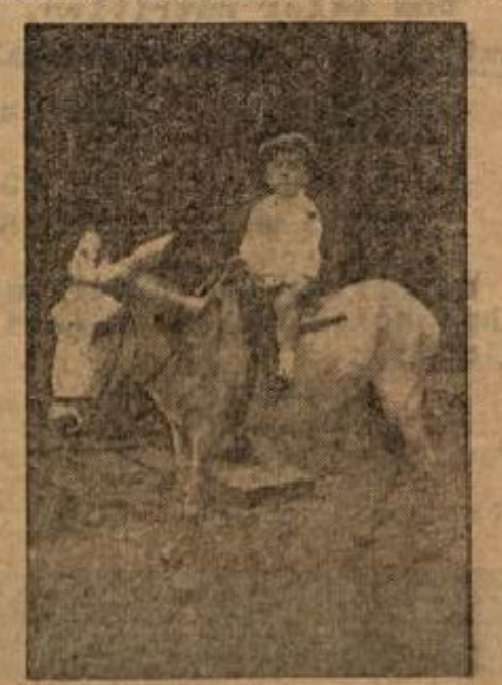

0 inleresonite Annibal Eouto Fitho fure fez canos a 2 do zancire nittiow.

\section{riso de Fra vassalo, 5 grs, do} riso de Frauciseo S. Pamlo, uma piratla da sorritso de Marina Garcia, 150 grrs. do falar do Ary Pereira, 15 krs. do eapricho da Jandyra Perieira, 20 grn. da eleganeia do Dediro M. Brasil, 3 igrs. to Coninecimento te Marin José M. Couto, 75 urs, das palavras doees de Macionilio S. Lima, 10 grs. dos olhos da Rosi Sintangeto. 100 grss, da graca de Oracina Cezar, 5 grr. dos modos de ternestina B. Fisnea, 25 sers. dos olhos attrahentes the Leonel Ferrcira, 20 ars, dos olhinhos vivos de Ira B. Bruno, 80 grs. do sorriso de Alice Santos, 250 Mrs. Clas linilas phrases de Jauary G. Nunes, 500 grs. do comprimento fos vestidos de Guiomar Campos, 300 grs: do olhar do Walter B. Carvalho, e por fim, pulveriza-ke $\mathrm{com} 3$ kilos da sinceridade de Maria da Gloria R. Gomes.

Doceira amorosa - Realengo.

* Achei a segainte reccita as passar pelo $5^{\prime}$ anno $B$, da Bseola José Pedro Varella:

250 grs. ito cahello da Nylsea, 20 grs. Ios oculos da Izabel, 400 grs. da boeca da Lelis, 100 grs, do andar da Lilliana. Ifistura-se tudo. depois unta-se um ponco de gerdura da pois unta-se um ponco de gordura da
Mfaria Lygia, dos olhos da Dyree, do uniforme da Lourdes.

Depois da bolo prompto, enfeitase com um pouco do falar da IIT, dos sapafos da Puth, do beico do Virgilio - Aranha.

\section{$\mathrm{N} O$ C I N E M A ...}

* * Andava 'Eu" passeiando no c:armpo de Săo Christovão, quando cleparei com uns rapazes e mocas os quaes comparef aos seguintes films:

Klavio M. "O rei do phosphoro": Spinele, Diocles e Dioclecio, "Tres Mostudeteiros": Dath, "O altima varâo sobre a Tarra"; Casimiro, "General York"; Alex, "Dr, R"; Mrs. ehacho, Peso Pesado"; Helio, "Tenente Sednctor": Gibierto Mincedo, "O Bem Amarlo": Carlos, "O Pro; motor Pablico"; Amalia, "Multier Prohithila"; Cariuen Fonseca, "Ufunhar Indomavel"; Yvonne, "Noiva do Cé": Buniog, "Loura e Seduetora"; Nathalia, "Mlullaer notoria": Zoler. ka. "Carne e o Diabo": Haydée Asknmpeño, "Uma Alina Livre.; Carmen, Denair e Nleia, "3 Garotas Litdiaas"; Buth, "Cavadora de Orro"; Osiris Nascimento, "Mndame Sat, tan".

C. F. - S. Chư⿱宀⿻⺀大ovāo - Ris.

4. a Querento organizar um film escolhi os seiguintes arlistas:

Lyeia, a eneantadora Normn Slaed. ror: Zelis, a efettante Jean Haviow: Odialys, o men eneanthdor Goomra orbien; Anacyr, o tenor José X:o. jica: Larn, s morena Lupe Velez. Bu, a Drinceza do paí das maraveWhas.

TToda ereança deve comprar o livro-"Vovo D'O TICO-TICO". A' venda. Preşa $5 \$ 000$. 


\section{NASCIMENTOS}

it 3 Nasceu o mehino Paulo, filhinho Io easal Diogenes de Paula Bittencourt D. Odette Salles Bittencourt.

it a Tata em festas o lar do sr. Antenor Figneira e de sua esposa D. Consuelo Figueira, por motivo do nascimento de sua filhinha Edelwein.

\section{A N I I ERSARIOS}

is is Faz annos hoje a menino Mauro Santos, nosso presado assisaante 6 amigainho.

75: te Completou seis annos sabbado nltimo a uraciosa Sarah, filhinha do Dr. Antonio de Queiroz.

if to Festejou hontem a passagem ae sua data natalicia a nossa amigoinha e leitora Geny Santos.

4t is Sylvio, o galente filbinho do sF. Oswaldo Pinheiro, festeja hoje a data de seu anniversario natalicio.

\section{N $O$ O C I $\mathrm{X}$ E M M A .}

용 is Estando eu a passeio por Bento Ribeiro vi os seguintes rapazes e mocas nos quacs reparei os seguintes films:

Abilio, "O ultimo varăo sobre a terra"; Esther, "Mulher Indomavel"; Censtantino, "Uma noite no cairo"; Djalma, "Cavalleiro da Noite"; Alvarino, "Voando para o Hio"; Ereilia, "Fiel ao seu amor"; Alice, "Cavadorat de ouro": Luiz, "Ama-me esta noite": Juvenai, "Assobiando no es. curo": Dolores, "Mnilher só aquella"; Gicorgina "Anjo e demonio", Eduardo, "Hei dos ciganos"; Alexy, "Noiva do céu"; Aracy". "' $\mathbf{A}$ procura de un amor", Aurora "Casamento liberal"; Odoripio, "Beilo para lodas"; Franciseo, "0 Bem amado".

\section{SECGRO DA DOCEIRA...}

*2 3 Querendo offerecer um boló a nossa sempre àmiguinha Ercilia ahi vae a receita:

100 gr's, da belleza de Aracy, 250 grs. dos olhos de Eduardo, 150 grs. das gracas de Abilio, 200 grs, do cabello de Luiz M., 600 grs, do sorriso de Odoripio, 50 grs. do andar ligeiro de Marío, 300 grs. da gordura de Alexy, 200 grs. do rosto de Constantino, 400 grs. das sobrancelhas de Au rora, 3 õ uma pitada da idéa ale Luiz, 1/2 kilo das valentias de Djalma, 350 grs. dos labios de Georgina

\section{E II LEIL $\triangle$ I O...}

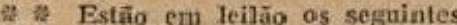
rapazes o mocas de Bento Ribeiro: Quanto dấo: pelo sorriso do Abilio? pelos dentes de Odoripio? pelos eabellos da Rtegina? pelas gracas de Manoel? pelo vestido branco de Aracy? pelos olhos de Alex? pela ealcy? pelos ohos de Alex? pela cal-
ma do Herculano? pelo tamanho de ma do Herculano? pelo tamanho de
Alexy? pelo porte do Juvenal? pela prosa do Constantino? E finalmente, quanto dắa pela querida leiloeim?

तै 3 th Bstâo em leillâo os seguintes slumnos do Lyceu de Artes e Officios - 1. anno Perito Contador:

Quanto dão: pola linda dentadura c polidez do Joẫo Baptista de Menezes? pelos bizodinhos do Mario $A$.

Mello pela mantinha preta e ver Mello pela mantinha preta e ver- melha do Armando de Oliveiral (Le-
leco)? pela valentia do Antonio Ferreira pela bondade do José Nogueira pelos cabellos louros do José Castro Neves?

20 anno Propedteticieo: Delá elegancia do. Paulo Lacerda? pela goe. dura do Mauriclo Simontob? pela boquinha do Eoneo Alenezes? pelos delícados pézinhos do Eduardo Raymundo? pela fardinha do José Luiz? pelo meio kilo do Edmundo Castro Novo?

1. anno Propedeutico: - Quanto dঙ๋̆ pelo queixinho do Arthur Branco? pelos dentes do Luiz Ross? pelos oculos do Domingos Ouro Fino? pela carinha to Jacy Moura? pelo corpo de athleta do Alfredo Santos? pelas delieadas mãos do Áffonso Pinto Carneiro Junior?

Admissũo - Ouanto dấo pela belJeza da Almir Barroso? pela sympathita do Sertio Savedra Cardosa? pepela graca do Roberto Peres, pela robustez do Amador Peres? pela Santidade do Armando Von Boreli Negreiros? E pela minha lingua de leiJoeira? - (Paulista).

N A B E R L I N D A ...

a $*$ Estäo na berlinda as seguintes menintas e meninos do $5^{\circ}$ anno B da Escola Cruzeiro:

Helena S, L., por ser bem edueada; José Luiz C $x$, por ser camarada; Maria de Lourdes S., por falar como nortisla; Wilson, por ser colado: Beatriz, por ser a mais adeantade da classe; Laria Holena S. F., por sostar muilo... muito... da Déa II.; Dulce N., por ser "do outro mundo": Margarida D., por ser graciosa: José F. B., por ser intelligente e engracado: Maria MI, por andar sem meias; Graciano R., por ser querido; Déa M., por ter ilndos olhos: Adal, por ser a mais camarada da classe: I.eda A., por se parecer com a Greta Garbo; Leda E.. por ser bonitinha; Yolanda M., por ser sympathiea; Hago M., Dor ser estudioso, e eu, por estar dizenda tudo isto em publico. - Arsene Lupin.

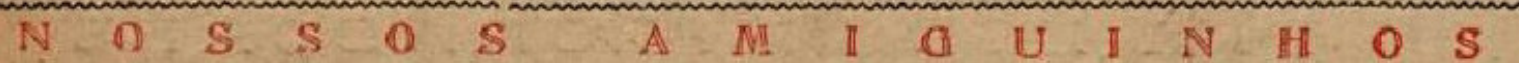
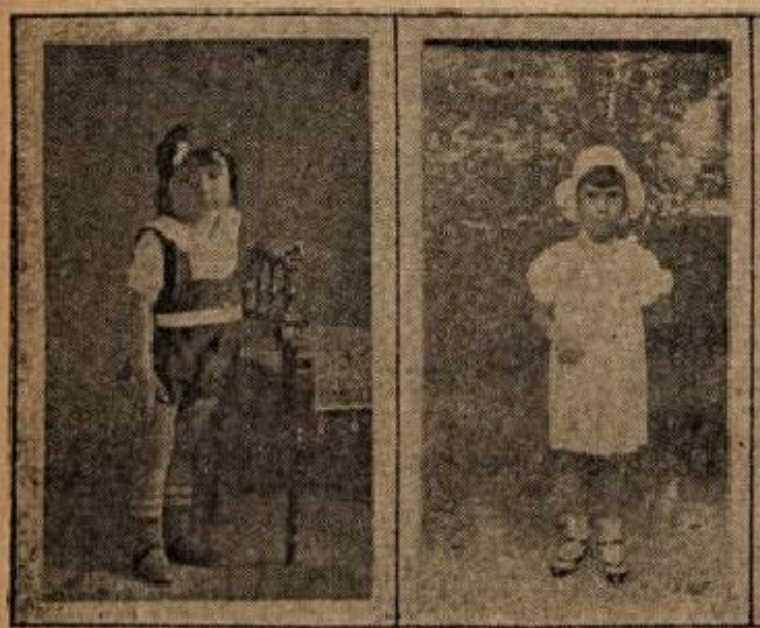

Jesé Caelawo, Who do Sr. Nossa amiguinho Jiára José Alcides Moraes
Ciunhà

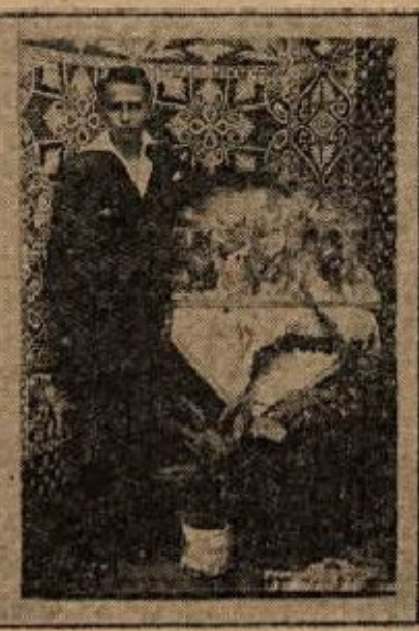

Nossa Peitor Egolina Cor deiro de Abreu

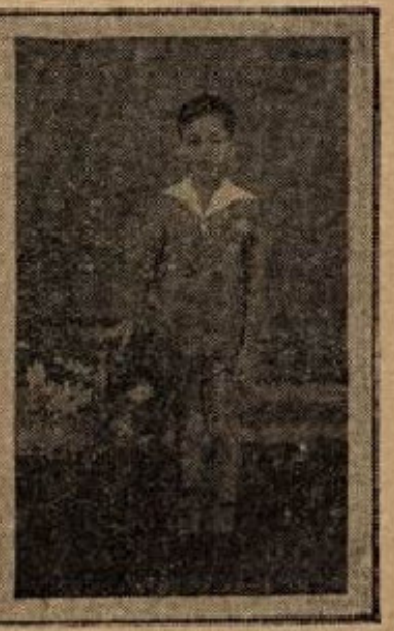

Nosso aniguinho o intellioente Cesar do Nascimentó

COMPRE O LIVRO - "VOVO D'O TICO-TICO". A' VENDA. PREÇO $5 \$ 000$. 
o TICO-TIC 0

NASGIMENTOS

* * Com o nasci. mento do me n ino O TICO-TICO MUNDANO

pela pose de Jeüo? pelo corpo de Luz Ouiriua? pelo brincathắ de Juca? pelas cantigas de Elza? pela boadade do Edgar? Ignacio, acha-se cm festa o lar do sr. Iguacio de Carvalho e de sua cxma. esposa, sra, d. Davina Jardim de Corvallo, restdentes ean Bello Horizonte.

*ै: Acha-se enriquecido, com o nascimento de um menino, que recebara o ponie de Affonso, o lar do $5 x$ Aftonso Vaz de Mello Carynlho, e de sua exma, esposa sra, d, Estellih, resittentes em Bello forizonic.

ya the Nasceram na capital de Săo Pralo: - Lucia Thereza, filla do st. Luiz Leal e de d. Maria Gonceicaño Leal. - Benedicta, filha do sr. Jose Adail de Martos, funcelonario do Patlacio da Justiea, e de d. Bencdietn de Oliveira Mattos. - Neycle, tilha do sr. Franeisco Nicolaci, Jusecionarîo da Repartiçio de Aguas $\mathrm{e}$ de d. Maria Nicolaci. - Aleides, fillı do sr Joset Pinto de Oliveira, auxiliar da firma $\delta$. Martins \& Cia, e de d. Olga de Oliqeira. - Olyuplo, filho do sr. Sylvio Marcondes e de d. Zalmira Marcondes.

* * Desde o dia 13 do mez ultimo que estít em festa o lar do sr. Pedra Salomâo, residente em Laguma, e de sea exma. esposa d. Waldira Soares Salomâa, pelo nascimento do seg filhinho Zatuir.

\section{A N XIVARS ARIOS}

a - s. Far annos hoje o metilno Armando, filhiaho do Dr. Sylvio Pa checo.

If से Passon sabbalo ultimo a da in natalicia do graciosia Marcella, fi. minla do ss. Fstevio da Cosia Pinto

\$2 : Completer hontein oito on1108 o estudioso Moacyr, filhinho do sr. Antenot Pinheiro.

is in $\Lambda$ nossa graciosa amiguinhat Margarida, filhinha do casal sr. Al varo Giuimarîtes - D. Odette Lima

Guimaries, festejou snte-hontem a passagen - do seu anniversavio natalición.

\section{E M L E I L $\bar{A} O \ldots$}

3 \& Estâo em teiläo os seguintes rapazes e mocas que frequentam o bairro do Riachuelo:

Quanto dão: pela kordura do Arý? pelo signalzinho to Francisec? pelas risadas de Adalberta? pelos tiseursos do Roberto? pelo comportaments do Alexurdre? pela pose do Durval? pela belleza do Morgado? pelos othos de Marlaxinlua? pela eraca da Yvonne? gela pose da Jaerra? pelo andar do Enio? pelo falar do Armando? peta estatura do Cyro? pelo rosto do Ay. dil? pelos vestidos de Nyone? pela baratinha alinhada do Edison? pelo sorriso do Osmar pelo porte do Delarey? pela elegancia do Dyrwal? pela bondade da Hilda? pelo bigodiaho do Caetano? pela allura da Narciza? pela formoosura do Aragaió? $\mathbf{E}$ quanto dăo pela lingua da leilocira?

\section{Princeza levaila}

- ํำ * Estāo em leilña is seguintes menints e menines da rui Barĩo de ST̃o Felix:

Ouanto dío pela voz de Russo? pelo andar de Yolarda? pela belleza de Angusto? pelo dente de ouro de Nirthalia? pelos ollos de Paco? pelo sorriso de Ephigenia? pelas poesias de José? pelos cabellos de Nininha?

Escove os seus dentes de manhat, f t Hoite $e$ após as refeiçóea, Iscovees, pelo menos, ie manis, ao meio dia c á noite. pelos trabalhos de Rosa? pela bocea de Elpixio? pela bondade de Tzaura? pela gordura de Afionso? pelas rodas de Benila? pelos othos ternos de Maluco? IE pela minha lís కua quanto dăo?

$$
\text { B. S. P. R. }
$$

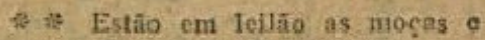
tapazes do bairro de Grajahu':

Quanto dîto Dela còr morema do Arthur? pelo sorriso de Carmilin? pelos cabelles de Julinha? pelos olhos de Céomar? pola elegancia de Car. litos? pela fala do Pedro? pelo sorriso de Fiza? pelos vestidos de Risolete? pela seriedade de Fernanda? pelo moda de Geraldo? pela altura da Ehza? pelo modo de andar de Cellna? pelo estudioso Nilo? B quanto diso pelo leiloeiro?

$$
\text { M A. }
$$

\section{N A B E A L I N D A ...}

* * Estắo na berlinda as sesuin. tes meninos e meninas da run Lygia (Olaria):

Rubens, Dor ser mnito delicatio; Nilsa, por ser querida: Dinm, por ser stegante; Aluysto, por ser boul o; Bunice, por ser engrieada; Attlias, por ser estimado; Jurncy, por ser elegante: Jorke, por ser bomzinho: Lẻa, pow ser gorda; Lygfa, por ser retraida; Eidas, por ser estudioso; Elra. por sate delicada: Ondina, por usar vestido curto; Alzira, por ter volaciio para reinha de 1931; Zulmira, por ser amavel; Leny, por set loura; B eu, por ser a mais engraendinlig da turma.

A. B. C.

\section{O BRASIL VALOROSO DE AMANHA}

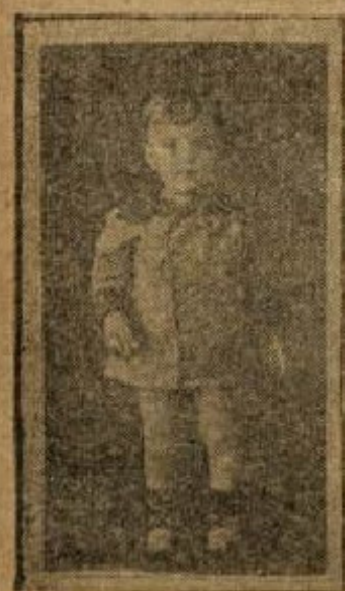

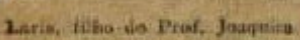
Gengalyes Pertira Filho,

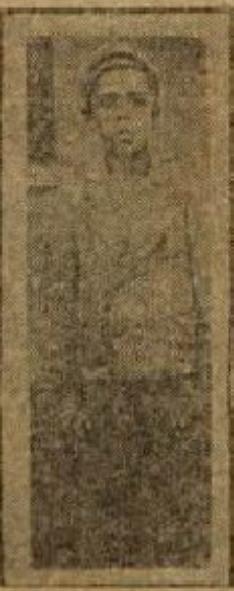

I v a s $c$ 18 a $a$ a

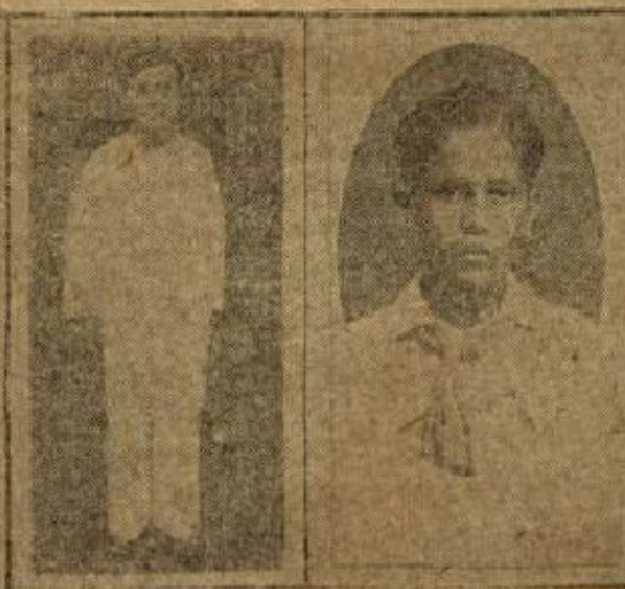

A $u r \&$ o

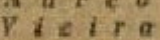

W $a>i \in r$ $V \in a$ d 0

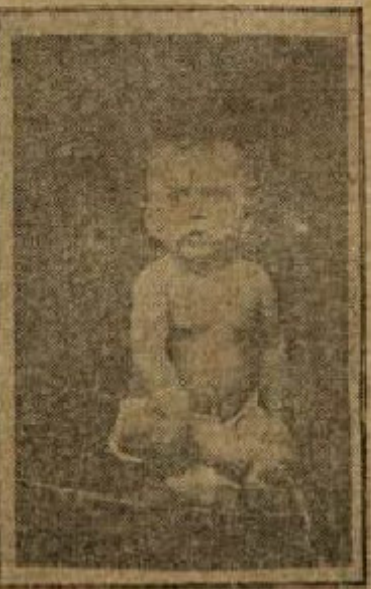

Therezinha de Jesurs Gorts faives

COMPRE O LIVRO - "VOVÓ D'O TICO-TICO". A' VENDA. PRECO 5\$OCOA.

Figura 19: T5, Ed. 1492, maio de1934, pg. 4. 
NA : C IMENTOS

at 0 o sir. Aehi. Ies Crivelado Salvafor e sua exma. es posa estăo do para.

betas com o mascimento de sua fitha Véra Terezinha.

* 0 sr. He:minit Fernandes, e 2 1 a exma. esposa estão com o $0^{\prime} \mathrm{r}$ em festas pela motivo do nascimeato de 2:a7 filha Noiran.

굴 Está em festas o lar do sr Olavo M. Oliveira e sua cxmna, espoxa d. Edelmira B. Oliveira, pelo nascimenta de sua primogenita, que renebeu o nome de Arjorie Ifar ia.

è * 0 sr. João Carminatti e sua exma. esposa lém o har $\mathrm{cm}$ festas com o nascimenta de seu primogenito Newion P-bem.

\section{A N I V E R S R I O S}

$\Rightarrow \geqslant$ Faz anos hoje o menino Ouintino Nieves, nosso leftor, residente era Belo Horizonte.

w. topassou domingo ultima data natalicia da graciosa Enlina, filhinha do Dr. Engenio Costa.

* if Completou ante-hontem oito primavěras a gentil Carmen, filhinha fo sr. Antonio Pereira Costa,

of se Osear Veiga, nosso estudioso amiguinho, vê passar hoje a data de sen aniversario nalalicio.

I M L E I L $\pi \quad \ldots$

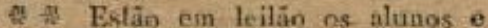
nlunas da Escolla N. S. das Dóres:

Ouanto me daro: pelos vestidos curtos de Neli? pelos dentes de Git. dinha? pela beleza de Blema? pela bondicle ale Adalgiza? pela usofura de Wanda? nela belcza if Maria Ce. Jeste? pelo minaro de Tomaz pela peraltiee de Gustavo? pelos modcis de

\section{TICO-TICO MUNDANO}

lo andar do Fernanto pela boea da Ol. tuinha? pelos oculos do Olgmar? pelos gestos da Marilda? E. quanto dảo pela

Joåo Baptista? pela elegancía? de Vasco? pelos desenhos de Laurinha? pelo comportamento de Julio?

*ै in Estão em leilăo os rapazes e mocas do "Colegio Independencia".

Oumito dán: pelo espelho da Candida? peco sorriso da Zeni? pelas risadas da Elisa? pela gordara da Lourdes? pelas respostas da Celina? pela sair da Glorita? pela estudíosa Yảra? pela delieadeza do Fernando? pela beleza da Alexandrinn? pela vipela beleza dil Alexandring pela vis tadores do Nunan? pelos dentes do tadores do Nunan? pelos dentes do
Exminio? pelas unhas do Alfredo? pe. la bondade do Sá? pelas palhacadas do Cès? pelo biesodinho do $\mathrm{L}$ all? quanto dăo pela mínha lingua?

$$
\text { 73. } \boldsymbol{P} \text {. }
$$

Escove os seus dentes de manha, á noite e após as refeiçóes. Escove= os, pelo menos, de manhã, ao meio dia e $a ́$ noite.

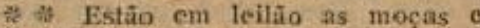
rapazes do Grajaủ.

Quanto dāo: pela pose de Elza? pelos othos da Carmita? pelo sart'o da Ceomar? pelo apelido do Pedro? pelos cabelos do Derval? pelas risadas do Grijalva? pelas sobrancelhas do Julinho? pelo comportamento do Geralda F.? pela elegancia da Clara? pela pose do Garlito? pela bondade da Maria Candida? Dela graça do Ge raldo Araujo? pela pele da Judith? pela delieadeza do Mario? reles can. tigas de Risoleta? pelos discursos de Nito"s pelos trabalhos de Niobel? pe- lingas da leilociro? - Prineipe En. cantado.

ㅊำ *ै Estāo em leilāo os seguintes afunos da Escola Gonçalves Dias, do $3^{7}$ ano 22:

Ouanto dảo pela tagarclice da Leda Enes? pelos cabelos da Edenir? pelo sorriso da Neide? pelos mestos da Nirce? pela gordura da Silvia? pelos olloós da Laís? pelo tamanho da Concericấo? pelo azul dos olhos da Marilena? pela quietude do Luiz? pelas travessuras do. Artur? pela pose da Aleione? pela sabedoria da Yeda? pula tristera da May? pelas palbaea. das do Orlando? pelas conversas da Alzira? pela vóz da Maria Alda?

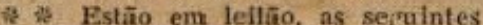
meninas e meninos, da escola experimental Manoel Bomfim:

Ouanto dīo: pelos lindos ollos de V: Hetema $\mathrm{C}$.? pelos eachinhos de $\mathrm{Mi}^{2}$. Augusta? pelos elaros dentes de L is pela graca de fodolfo? pela bocquinha de M. Lauro? $\mathrm{pc}^{\mathrm{T}}$ sorriso de Anice? pela elizancia de Ires S.? pela tagarelice de Alberto? pela bondade de Sibele? e quanto dă. para eu, organizadora do lelläo?

* * Le Lula em Botafoge. 2uanto dăo: pelos sorrisos de Ana? pelos olhos de Irene? pela pasta de Maria? in boina de Olua? pela linda voz de Evaristo? pela cisma de Wento? pe It graga de Josefina? I olos vestidi. ahya de Ixamra? pola elegancia de Emilia? pela alemria de Véra? pelo andar de Almeirindu? pelo geitinh tc Yaria? pela prose te Crizuliala? pelo sorriso de Heliete?

\section{OS CONDUTORES DO BRASIL DE AMANHA}

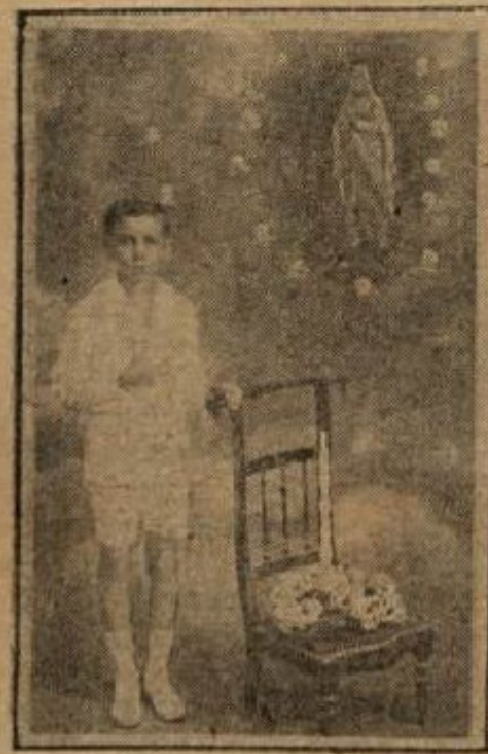

Nosso umiguinho Jair, t.3 dix de sta $t^{*}$ comunhito (Bita)

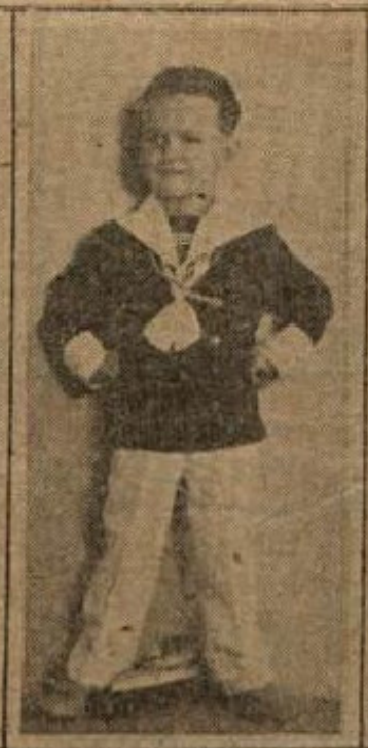

Octavio, Filho da Dr. Octavio de Araujo Novaess - São Pausio

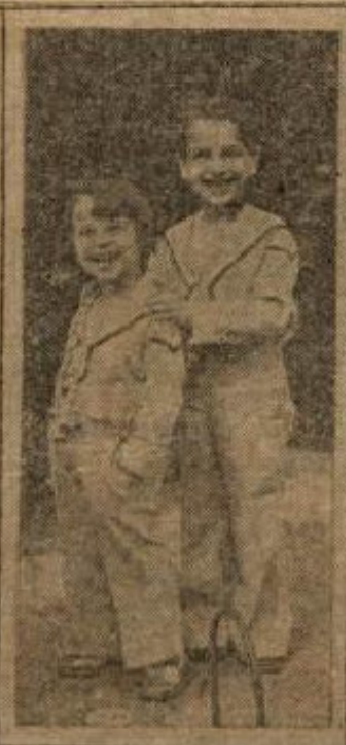

Eny e Neil. fillios do in. Adallierto Menezes - S. Parilo

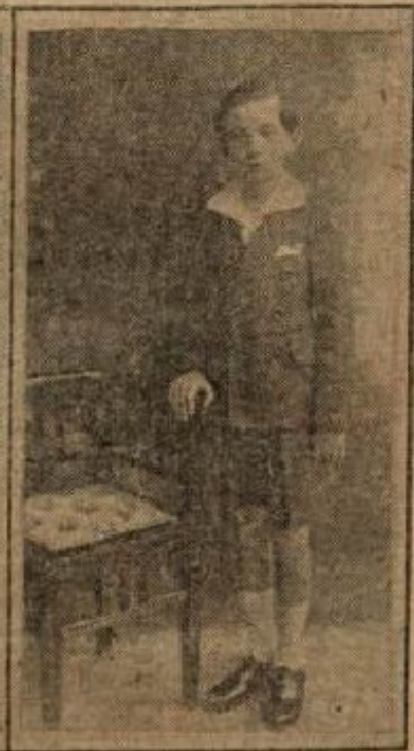

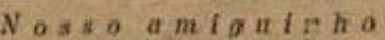
I lid d $\begin{array}{llll}i & 0 & A\end{array}$

"VOVO D'O TICO-TICO" E' O LIVRO NECESSARIO A' CRIANÇA. A" venda 


\section{TIC $0-$ T I C 0}

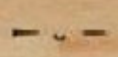

4 - Julho $-193 i$

\section{ANIVERSARIOS}

* Passou a 18 do més findo a data natalicia da interes: sante menina Haydée

Freire de Souza, filha do Sr. Anchy. E M V I A G E M... ses Benttenmuller de Souza e D. Ruth Freire de Souza.

* Faz anos hoje o estudioso Arnaldo Vieira da Nobrega, nosso essinante residente em Juiz de Fóra.

* * Hariazinha Gumaräes, nossa prendada amiguinha, festejoa ante hontem a passagem de seu aniversa. ris natalicio,

\# * A 30 do mès findo completou dez anos o nosso leitor Murilo Nasci. mento.

ข้ *ै Fez anos hontón a menina Laura, filhinha do Dr. Luiz Bastos.

NoS A R E S . . .

* * Partiu da praia de Copacabana o aviăo "g de Fevereiro". Ia repleto. Tinha como aviador Pomario, como mecanico Helio, e eram passaneiros os meninos e meninas que se neiros os meninos e meninas que se
segte: Reaato, Lacy, Carlos, Sylvia, Carmelio, Juliana, Cal, Marina e Eralto. No caminho encontramos os seguintes meteóros: A garóa que era Blza, o vento que cra o Walter La, a geada era a Celia, o relampago era o. Walter, a tempestade era Haydée

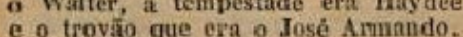
e o trovía que era o José Ammando. Proseguimos a viagean sendo encontrados ainda a Lua que cra Rachel,
b orvalho cra o Paulo, a Noite era Yole. Continuamos a viagem em linha réa e avistamos as três Marias que tram: Ma. Helena, Mª de Lourdes e Mi". Thereza, o Sol que era o Gildo, Venus era Vera, a Estrela Dalva era Venus era Vèra, a Estrela Dalva era
Vvone. A seguir encontramos o Dia, era este o Zéré. Finalmente, chegamos ao logar de onde partira o aviáo ag de Fevereiro" e onde fomos bem recebidos. Estrela Pasageira

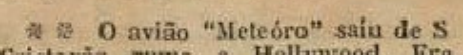
Cristovão rumo a Hollywood. Era nviador Zézinho e a mecanico José. Passageiros: Véra, Carlos, Elvira e Ruth.

Durante o Dercurso de viagem fomos surpreendidos pelos seguintes meteóros: Celìa, a garòa; Claudio, o vento: Marilia, a tempestade; Olavo, - relompago. Indo em segrida aterrisar em Hollywóod onde vários as. tros einematoeratieos já o esperavam tros cinematogratieos

M E T E 0 R $0 \mathrm{~S} \ldots$

*2) Durante a viagem no "Cap. Areotta" encontramos os seguintes meteóros:

José, o orvalho; Euvira, a neblina; Carlos, o relampago; Zezinho, o troหãอ; Nany, a geada; Claudio, o calor; Celia, a noite: Olavo, o vento; Marilia, a tempestade; Véra a garóa. $\mathrm{E}$, ea, J. F. C., 0 dia.

E II L E I L $\pi \quad 0 \ldots$

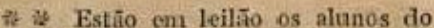
Externato Santo Antonio Maria Zacaria.

Quanto dảo: pela cabeça raspada do Antonio Valentim? pela franginha do Mario? pela graça do Antonio Monteira? pelo andar do José Carlos pelas brincadeiras do Joaqu'm? pela forca do Léo? pelos botóes da farcla do Anibal? pela altura do Nelson? pe. las risadas do Tiocles? pelas graças

Escove os seus dentes de manliă, á noite e após as refeiçōes. Escove$\left\{\begin{array}{l}\text { á noite } e \text { após as refeiçócs. Escove- } \\ \text { os, pelo menos, de manha, a meio }\end{array}\right.$ $\left\{\begin{array}{l}\text { os, pelo menos, } \\ \text { dia e á noite. }\end{array}\right.$

\section{do Ary? pelo compor-} A NO tamento do Par's? pelas graģas do Marcelo?

ำ lăa os seguintes mentnos da ru Benjamin Constan:

Quanto dẫo: pelos gestos de menina do Aranha? pela graca da Ilda? pelos cabelos lisos da Estela? pela valentia da Jaeira? pelos olhos cas. tanhos da Ilda pelas peripécias do Marcolino pela bicicleta do Carlinhos pela beleza do Preguinho pelas mracas do Levi? pelos passeios do Tedy? pelas shooteiras do Anibal?

*ี * * Estẫo $\mathrm{cm}$ letlẩo as seguintes nocsas e rapazes da Remeteçio Nova America:

Quanto dão: pelo sorriso da Elzx T.? pela elegancia da Ida T.? pelo bigode do Betinho? pelas costeletas do Aleixo? Delo bonet do Arsenio? pelos cabelos da Brigida? pela boca da Ida? pela ligeireza do Mineiro? pela bondadie do Caetano? pelo sorriso da Zizinha? pelos olhos da Elodia com Euchides? pela bondade do Luiz? Dela gentileza do Manivela? e quanto dăo Dela inteligeneia da leiloeira?

* * Leiläo de mocas o rapazes do Meyer.

Quanto dẫo: nelo andar de Zézé? pela gentileza de Djanira? pela graca de Julia? pelo comportamento de Jandira? pela delicadesa de Dalva? pelo dente de ouro de Dolores? pelos lindos dentes de Maria? pelos eabe los de Anita? pelos sorrisos de Le. da? pelos olhos de Luzia? pelas meias curtas de Zuleika? pela pose da Luluca? pelas risaddas de Helio? pela graca de Amerieo? pelo andar de Mylsom pela elegancia to Gauracy? pelat voz do Dylo.

Leiloeiro despeilado

\section{NOSSOS QUERIDOS AMIGUINHOS}

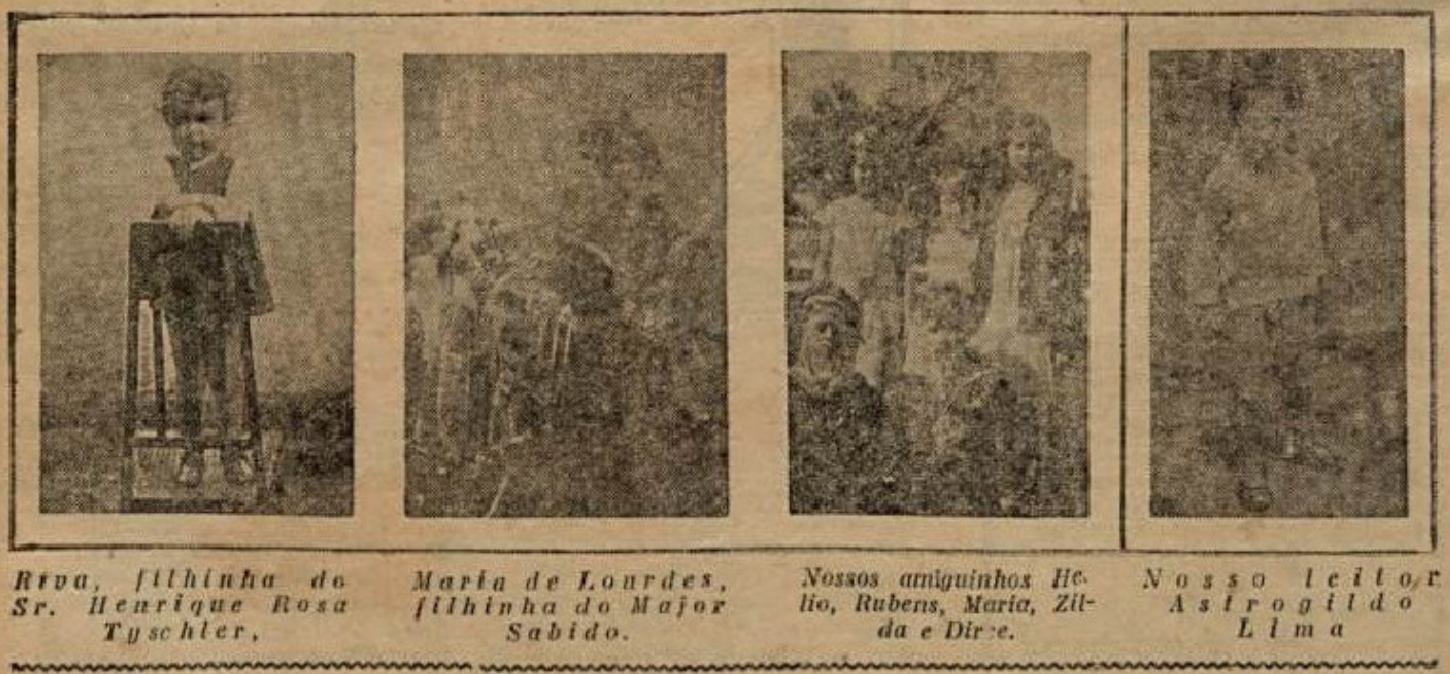

QUER UM BOM LIVRO ? - COMPRE "VÔVÓ D'O TICO-TICO", A' VENDA. 


\section{OS AMIGUINHOS D'O TICO-TICO}

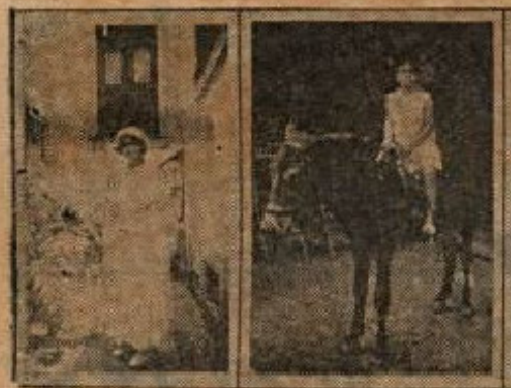

$A$ d $r i a n a$ Ja $\cos r$ e ma

$p a d i l \hbar a$

o livetra Rodrtgaes

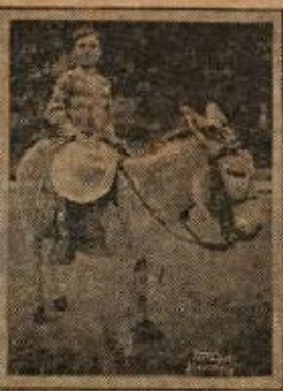

Art, fulno do sir, Joal ar. ria Virecencelles - do bait.

C. Clapaia iring dota ea.

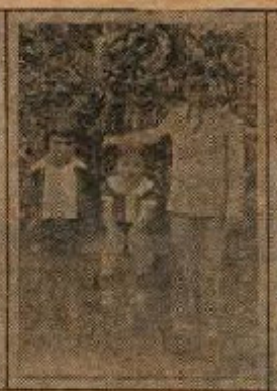

Failigr, Jay a Eider fi. has do Sn Epgio Nos. cinterter.

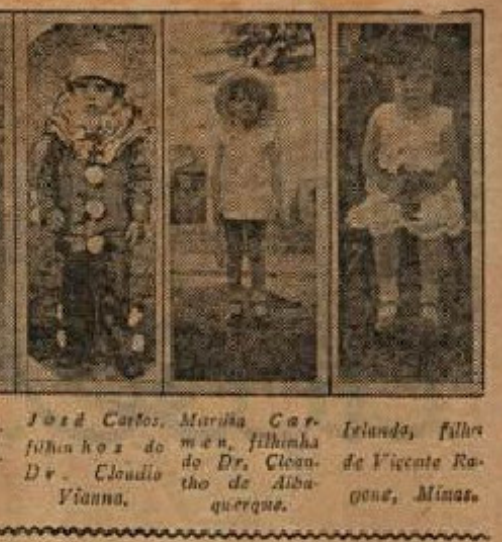

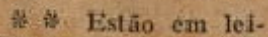
lão os alunes e alunas do $4^{\circ}$ ano do Grupo Escolar do Piaul.

Quanta me dấ: pelos cabelos de Ma-

is is Pasou hontem a data natalicia da gracioa Dulee, filhinha do Dr. Ulavo Pereira Leste.

Ab th Vin psssar sexta-feira ultima a sua data natalicia a gracíosg Marina, filhinha do Sr, Esteväo Correia.

\section{E M L E I L $\mathrm{A} \quad \mathrm{O} \ldots$}

* Estão em leilão as seguintes meninas da $1^{*}$ série $n^{*} 2$, do I. LaFayette.

Quanto dão: pelo ti;o Primo Car. nera da Thais? pela tristeza da Aurea? pela grande aplicacto da Elita? pela sorriso da Dulce B? pelos mo. dos infantis da Dulce T.? pela amizade que a Alba tem á poesia? pela altura da Hilda? pela amizade da Norma com a Edeloria? pela amizade que Elza, Yeda e Zaira tem á D. Mayar? pela alegria da Daluza? pelo aeanhamento da Gilda? pelo sorriso constante da Marina $V, f$ pelo andar da Larina D. ? pelo olhar da Bertha A.? pelo tipo claro da Bertha B.? pelo tipo "mignon" Aa Geysa?

Ealith, filhinha do $\mathrm{Sr}$. Andrề Mont nil.

*3 passou sábado ultimó a data natalicia do nosso estudioso amiguinho Oscar Boaventura Guimaräes, residente em Säo Pátulo.

늘 te 0 nosso amiguinho a leitor Faluardo Cardoso de Me"o completou hontem oito anos de idade. rina Castro? pelo adiantamento de Isaura? pelos desenthos de Celio? pela gordura de Luiza? pelo eapricho de Laurinha? pela delieadeza do $\mathrm{Se}$ bastiâo Carvatho? pela bondade de Nativa? pelos dentes de Marina? pela voz de Dulce? pela graça de Edgar? pelo comportamento de María Jasé? pelas travessuras de Carmosina? pela simpatia de Ninita? pelo mo. reno de Antonio Fonseca? pela mo. leza de Ilda? pela esperteza de Aparecida? pelo andar de Evangelima? e quanto đăo por $\mathrm{mim}$, organizadora do leilă้o?

\section{SECCÃ̃O DA DOCEIRA...}

is 2 Querendo oferecer um bolo a moradores de Tanguá, escolhi os seguintes ingredientes:

$200 \mathrm{grs}$. do sorviso do Reynaldo, 150 grs. do tamanho do Geraldo, 150 grs. do acanhamento do Antonito, 100 grs. do sorriso do Norival, 75 grs. do andar do Oldemar, 175 grs, da ins teligencia do Anisio, 100 grs, da be. leza do Luiz, 150 grs, da simpatia do Amavel, 700 grs. da pose do Lauro, 100 grs. da indiferenca do Mimi. Bate-se com a sinceridade do Lafayet. te e leva-se a forno com a bondade do Braga.

Doceira misteriosa

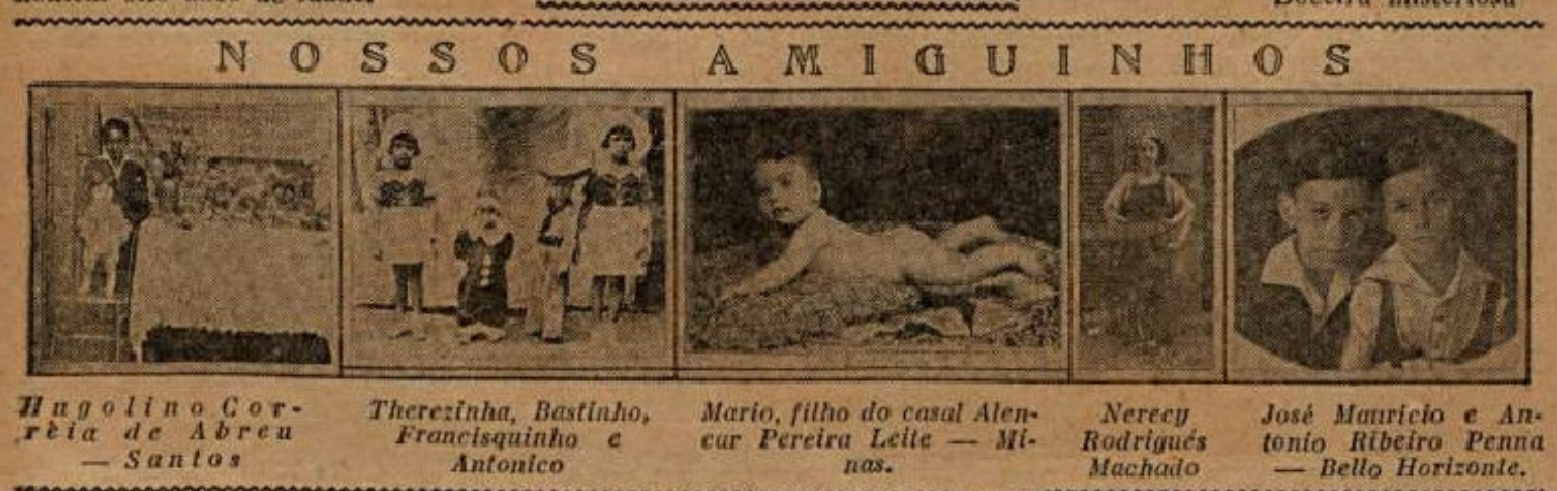

Toda criança deve comprar o livro - "VOVOO D'O TICO-TICO", A' venda. Preço $5 \$ 000$ 


\section{N. $\triangle$ S GIMENTOS}

* * Nasceu a 7 fieste mez a linda Carmen, filhinha do casal sr. Ant enor Carvalho de Oliveira e de D. Carmen Salles de Oliveira.

if is Cliama-se Ruy o robusto primogenito do casal Lauro Figueireda - D. Emilia Castro Figuel. reda.

\section{A N N I V E R A R I O S}

* * Faz annos hoje o menino Ars, fithinho da sr. Oscar Veiga.

20 Completou seis annos no dia 10 deste mez a graciosa Lucy, filhinha do Dr. Renato Jorge.

$\Rightarrow$ * Mario Luiz, galante filhinho đo capitấo Jayme Pinheiro, festejou tontem a data de seu anniversario natalicio,

N 0 C I N E M A ..

* * Querendo organizar um film Tue scrà intitulada "Idade de MuIher", $c o m$ varios alumnos do $5^{\circ}$ anno $\mathbf{B}$ da Escola 7, fiz a seguinte disiribuiçăo:

Zenaide, a moreninha Kathe von Nagy: Auth, a blonde Jean HarJow: M. Magdalena, a deusa Greta Garlio: Antonio, o comico Harold loyd: Wanda $\mathbf{~}$., a sentimental Mirra Loy; M. Amelia G., a infantil Janet Gaynor; Celina, a irrequieta Conchita Montenegro; Waldyr, o irrcsistivel Clark Glabe; Olinda, a encautadora Joan Crawford; America, a colossal Kay Francis; Armanda, a fantaslica Frances Drake; Hugo, o romantico Ramon Novarro; Amneris, a Iyramidal Norma Shearer: M. de tourdes B.. a Madge Evans; Octacilia, a indifferente Adrienne Ames: Osorio, o patricio Raul Roulien; Palmyra, a Katharine Hepburn; Dora, - levada Dorothy Jordan; Léa Assis, 3 inerualavel Dolores Del Rio; Joss M., O futrepido Jim Mc Coy.

Iu... a incrivel directora impro. visaita. - Alvamar M. S.

* - Foram contractadios para fazer tum of fllm "Aunôn", alguns alumnos do G. M, de B. Mansa.

Cléa, a encantadora Conchita Montenegro; Celso, o nosso patricio Raul RouJien; Clia, a fascinante Norma Shearer; N. Soares, - encantador Robert Montsomery; Helena, a deslumbrante Kay Franeis; "Al. meida, o seu incomparavel galâ George 0 Brien; Ara. cy, a meiga Janet Gaynor; Wilson S., 0 sympa. thico Charles Farrell; ColIette, a pequena Shirley Teniple; Ismad, o lindo Lionel Barrymore; Myriam,

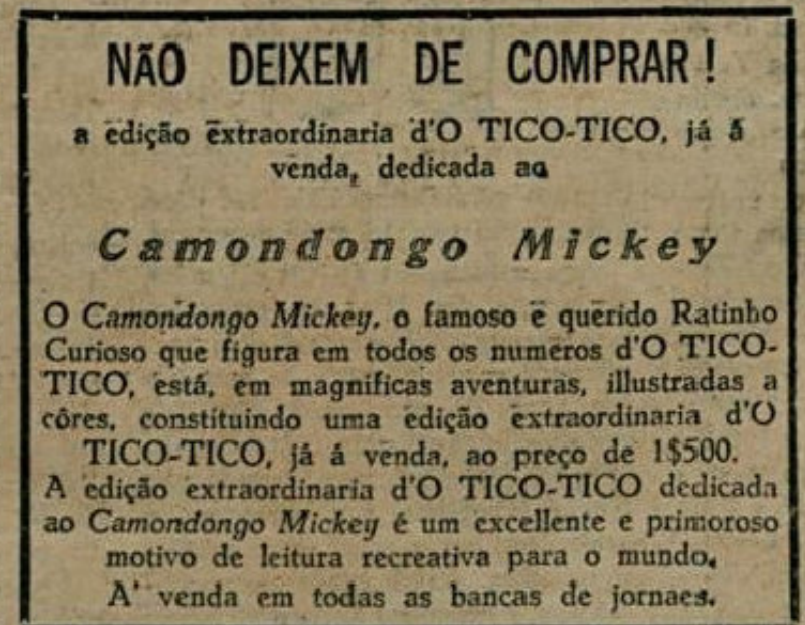

B II L B I L $\pi$ O...

8 If Estáo em lei. ta๊o as inoca e rapazes da Tua Uruguay: Quanto dino: pelos

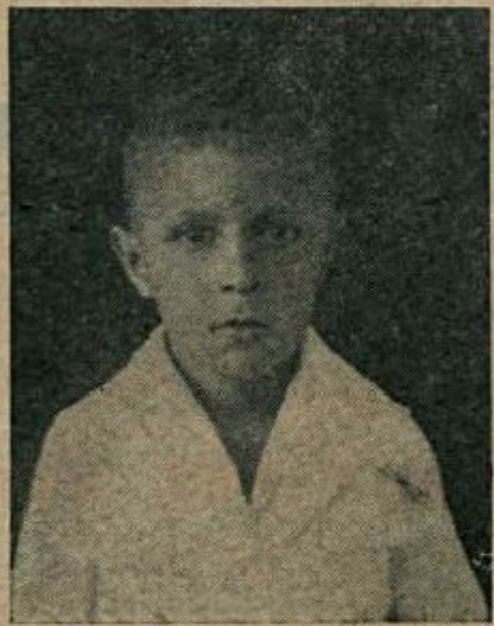

o menino Antonio Monteiro Balāo que fer annos em 29 de Navembro b $\mathrm{mm}$ dos nossos queridos leitores.

Jaon Crawford: L. Godinho, o Johan Barrymore; Me. Gloria, a gosada ZaSú Pitts: Daryo, o John Bolles; Edmès, a quieta Evelym Venahle; José Camargo, o irresistivel Clark Gable: M*. Apparecida, a amorosa Myrna Loy; Alvaro, o pensative

Escove sews denten, ma nifo llealte a laso un hygiene buccal. Fasa unia tigcira massagem sobre at gengivas, escovando-
para baiso of de baixo para cima.

William Farrell: Carmelia, a inesquecivel Elissa Landi; Cieero Bittencourt, o querido Frederich March; Córa, a rísonha Collen Moore; Lair, - gosado Maurice Chevalier, Adebide, a formidavel Jeancite Mac Donald.

eu, a loura Jean Harlow.
mitchos do vestido da Odette? pelos modes da Thereza? pelo andar da Ida? pelos dentes da Neusa? pelo sorriso da Léa? pela graça da Kimié? pelos cabellos da Yalda? pelo pentcado da Augustinha? pela elegancia do Alberto? pela gordura do Danilo? veto signal da Safie? pela delicadesa da Midoria? pela altura da Lourdes? pelo salto alto da Dulce? pelo bigode do Jorge? pela innocencia da Marilda? pelas risadas da Nin? ? pela pose do Heitor? pelo repartido da Véra? pelo sorriso da $\mathrm{Ma}$ gdalena? pelo vestido rosa da Joann:? pelo olhar da Ruth? pelas rela. cẽes do Evaristo? pelos olhos do Autonio? pelas sobrancelhas da Iza? pelas gaiatices do Waldemar? e quanto dẫo pela lingua do Ieiloieiro?

\section{SELCẼO DA DOCEIIA...}

*f * Querendo fazer urm bolo para ser offerecido á professora D. Palmyra, da Escola Epitacio Pessoa, tirei es seguintes ingredientes do $4^{*}$ arno $\mathrm{B} \cdot \mathrm{V}-3$ :

500 grs. da formosura da Clelia, 900 grs, da gentileza da Marilhía, $200 \mathrm{grs}$. da graça do Arthur, $300 \mathrm{grs}$. da prosa do Euclydes, $90 \mathrm{grs}$. das travessuras do Agostinho, 100 grs. das brigas dó Avelino, 90 grs, da faIa do Ezequiel, 290 grs. dos olhos de Licio, 100 grs. do beiço do Benigno, 500 grs. do nariz do Djalma, 760 grs. do sorriso do Mario. Como fermento: $\mathbf{7 0 0}$ grs. do sorriso de Euvira, $100 \mathrm{grs}$. das piadas do Gastão, 560 ers. dos cabellos do Nilzon, 100 grs. da voz do Antonio, e meia cother de chá de minha lingua ferina. - H. R. S.

\section{N O J A R D I M ...}

Fै W Querendo, em nome das Dlumnas do $5^{\circ}$ anno B da Escola "Chile", offerecer uma corbeille de flores á nossa professora D. Adelir Albuquerquer, escollhi as séguintes do meu jardim:

Marilia, um lindo amor. perfeito; Guilhermina, uma bocea de leão; Ilda, uma gracíosa acucena; Énéle, uma rosa; Maria Elconora, uma mimosa violeta; Regina, uma magnolia; Maria Julia, um pequenino myosotis; Zoreth, uma camelia; Lygia, uma linda margarida: Ninsa S., uma cravina; Lucia, uma afamada Victoria Règia; Olinda, um chrysanthemo; Valda, uma hortencia; e eu o cartäo de visitas que levava os seguintes dizeres: Dedicada mestra, D, Adelir. Acueena mysteriosa

"VOVO D'O TICO-TICO" E' O LIVRO NECESSARIO A' CREANÇA. A' venda. 
NO JARDIM...

* * Querendo offerecer uma cesta de flores ao nosso querido collega Nelson, escolhi num Jardim as seguintes flo. res:

Hetio, um lyrio; Celio, um boga. ryy: Alzira, uma rosa chá; Adelailde, uma violeta; Ecias, um amor perfeito; Concciçăo, uma orchídéa; Ruy, um copo de leite; Lygin, uma camelia. René, um cravo; Weldecrar, um botão de ouro; Rudes, uma dhalia; Nilton, um crysanthemo; Francisco, um jasmin; Neuza, uma rosa; Bdna, uma papoula; Neuza P.. uma Jacin. ta; Valerio, uma bocca do leấ; Jorge, um myosotis; Dorothy, uma tulipa; Cely, uma cravina; Odette, uma bonina. Luiza, a cesta e Otto o laço de rita. A cesta serí entregue ao colleza pela sua admiradora.

N O C I N E M A...

는 눌 Querendo organizar um film escolhi os seguintes meninas - meninas de Bento Ribeira como ertistas:

Alzira, a seductora Joan Crawford; Nelson, o nosso querído compatriota Raul Roulien; Adelaide, a sympathica Claudette Colbert; Nilton, o irresistivel Clark Gable; Joffre, o antipathico Adolphe Menjou; Rudes, a maravilhosa Lupe Velez; Conceiçấo, a amorenada Rosita Mo reno; Neuza, o Ingenua Janet Gaynor; Carmen, a travessa Jean Har-

Fow; Valerio, o amoroso Mauricio Chevalier; Francisco, o celebre Josó Mlojica; Ruy, o destemido Tom Mix; Celio, o adorado Ramon Novarro;

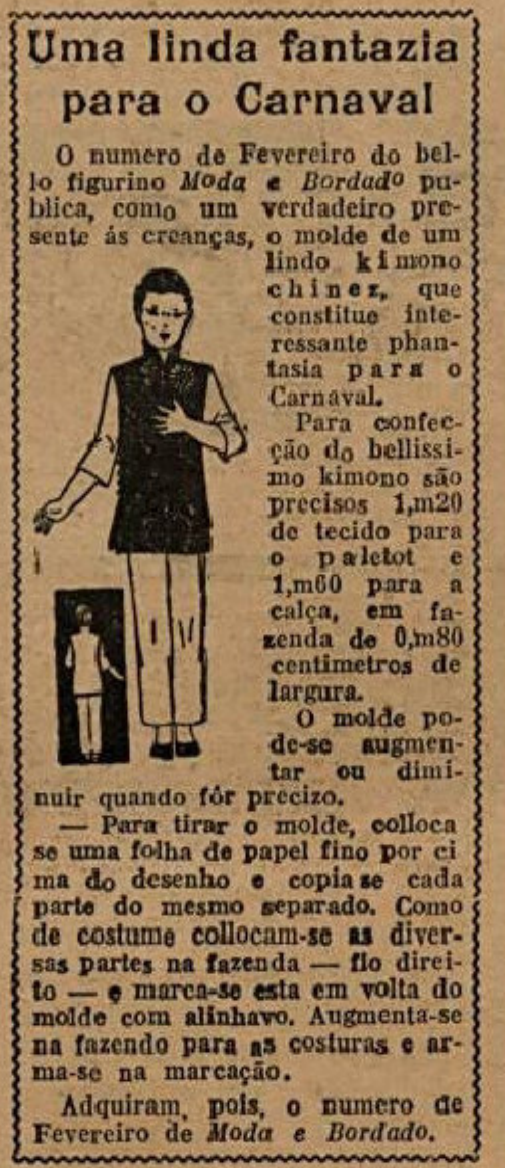

19-1evereiro- 1995

Ecias, o Incompara-

Neuza P. a querida Sylvia Sidney; Lygia, a deliciosa Ly.

MUNDANO

- Tom Tuler. E et, a amorosa Mar. lene Dietrich.

Artista mysteriosa

B M L E I L $\pi 0 \ldots$

* Lelláo dos aIumnos do Curso de Admissĩo do Collegio "Sylvio Leite".

Quanto dão: pela beleza sem par da Lourdes Cantanheda? pelos olhos da Sylvia Leiter pelo perfil do José? pela "modestia" da Sylvia Moreira? pelos olhos da Lourdes E. Branco? pelas gracinhas do Roberto? pela graca do Placido? pela meiguice da Else? pelo narizinho da Cybele? pela calma do Camillo pelos eachinhos da Yedda? pelos dentes da Lourdes Monteiro? pela "gordura" da Licy? pela "pouco falar" $\mathrm{d}_{\mathrm{a}}$ Dína? pelo comportamento da Yara? pela altura do Nelson? pelas sobrancelhas do Armando?

$\mathrm{E}$, terminando, quanto dão pela mascote da turma a

\section{Gatinha Nervosa?}

O Senhor dará um mágnifico pré. sente so seu filhinho, comprando bello livro "Meu Livro de historias". $A^{\prime}$ venda $\mathrm{em}$ todas as livrarias.

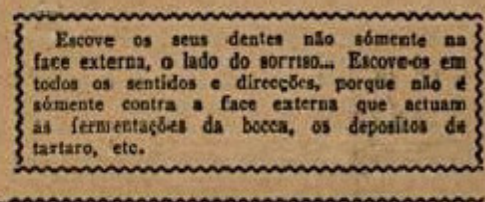

$A M \mathbb{I}$ G $U \mathbb{I} N \mathbb{N}$ O S
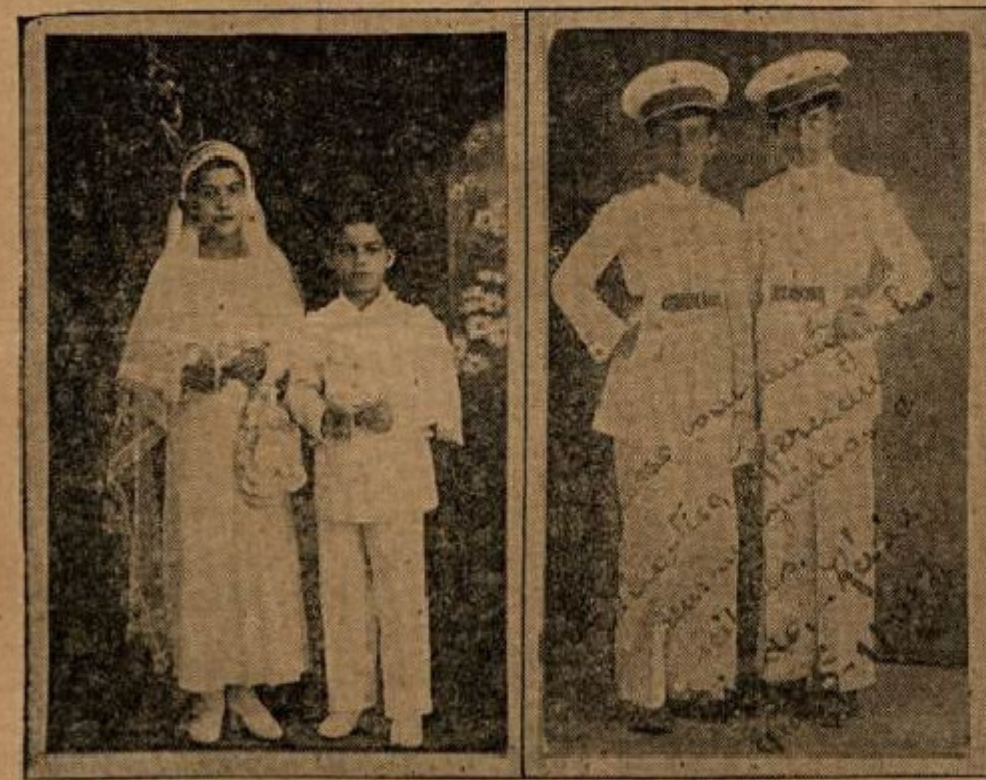

Gitsea e Jost Luiz, twhinhos do sr. Rialdo e Renio, dois amigninhos in Luiz Polydoro.

condicionaes do TICO-TICO.

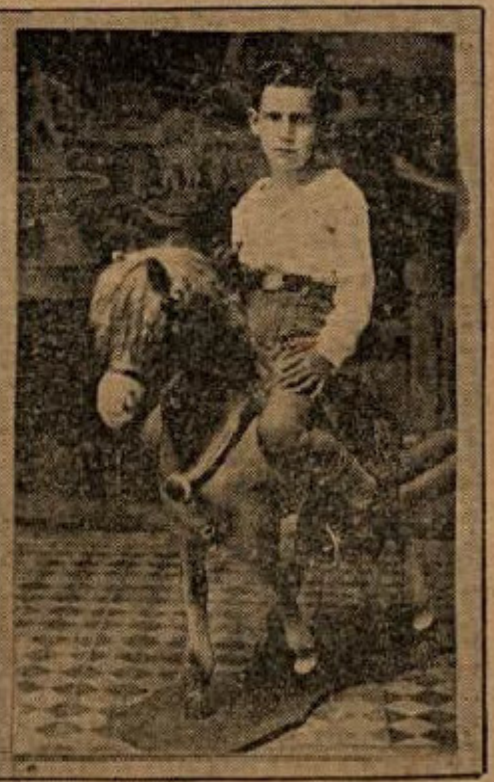

0 galante Marillo, filhinho do $s r$. Benjamin Saad.

Figura 24: T10, O Tico-Tico Mundano, Ed. 1535, fevereiro de 1935, pg. 6. 
Como se observa nas imagens anteriores, todos os textos da seção O Tico-Tico Mundano apresentam um padrão bastante específico: o título da seção centralizado; no cabeçalho à esquerda o nome da revista, no meio a paginação e à direita a data da edição; no corpo dos textos, há os anúncios da coluna social, com textos produzidos por adultos e por crianças. Ressaltamos ainda a presença de fotos dos leitores em todos os textos analisados, e a ocorrência, em quase todas as edições, de anúncios publicitários da própria editora, no rodapé, e de avisos sobre higiene pessoal e saúde, misturados aos anúncios da coluna.

No que diz respeito às fotos publicadas na seção, observamos uma distinção entre as legendas atribuídas a retratos de meninas e meninos misturados, em que as crianças são chamadas de "amiguinhos" e "leitores". Porém, nos textos T5 e T6, há apenas fotos de meninos, enaltecidos nas legendas como "O Brasil Valoroso de Amanhã" e "Os Condutores do Brasil de Amanhã" respectivamente. Compreendemos, com isso, que a revista conferia apenas aos meninos a esperança de um país melhor, projetando-os em cargos de chefia tanto na política quanto no mercado de trabalho. Se a infância era o futuro do país, esse futuro só dependeria das crianças do sexo masculino, perpetuando, assim, as relações de poder entre homens e mulheres nas famílias e na sociedade em geral.

Também ressaltamos o fato de tais imagens correspondem a retratos familiares e que as vestimentas das crianças - todas caucasianas - indicam um alto poder aquisitivo de suas famílias, uma vez que, àquela época, tais retratos eram inacessíveis para a maior parte da população, o que aponta para uma noção de público mais restrito da revista: os leitores eram crianças brancas e de famílias abastadas - a este pequeno grupo é que pertencia o futuro do país. Apesar de a inserção dessas imagens ter sido realizada pelo corpo editorial da revista composto apenas por adultos, é necessário destacar que esses indícios de seleção de público nos permitem também ter uma noção mais precisa de quem eram esses enunciadores infantis e quem seria seu auditório. Há um claro recorte racial e social dos interlocutores ora observados.

Em relação ao corpo do texto, isto é, aos anúncios da coluna, observamos que os avisos de aniversário, nascimento, batizado, entre outros também escritos por adultos, aparecem sempre antes das colunas de autoria atribuída às crianças - com exceção à edição de T10, que não conta com textos de autoria adulta -, estabelecendo-se, assim, uma hierarquia de importância entre os dois tipos de enunciação e de enunciadores - estando a criança sempre em segundo plano. Os enunciados infantis apresentam a mesma estrutura composicional de gêneros como coluna social e receita, porém, o assunto abordado nas produções das crianças 
não é o mesmo que o esperado para esses gêneros discursivos, como podemos observar no segmento selecionado, em que o leilão anunciado e a receita de bolo são totalmente fíctícios:

Estão em leilão as seguintes meninas e meninos, da escola experimental Manoel Bomfim: Quanto dão: pelos lindos olhos de $\mathrm{M}^{\mathrm{a}}$ Helena C.? pelos cachinhos de $\mathrm{M}^{\mathrm{a}}$ Augusta? pelos claros dentes de Luci? pela graça de Rodolfo? pela boquinha de M. Lauro? pelo sorriso de Anice? Pela elegancia de Ires S.? pela tagarelice de Alberto? pela bondade de Sibele? E eu quanto dão para eu, organizadora do leilão? [Grifo nosso] (T6)

Querendo offerecer um bolo à nossa sempre amiguinha Ercilia ahi vae a receita: 100 grms. da belleza de Aracy, 250 grms. dos olhos de Eduardo, 150 grms. das graças de Abilio, 200 grms. do cabello de Luiz M., 600 grms. Do sorriso de Odoripio, 50 grms. do andar ligeiro de Mario, 300 grms. Da gordura de Alexy, 200 grms. do rosto de Constantino, 400 grms. Das sobrancelhas de Aurora, 350 grms. do genio de Juvenal, uma pitada da ideia de Luiz, 1/2 kilo das valentias de Djalma, 350 grms. dos labios de

Georgina. [Grifo nosso] (T4)

Nestes excertos, observamos que os objetos postos em leilão, bem como os ingredientes para a receita de bolo são, na verdade, características de seus colegas tidas como positivas: "lindos olhos", "cachinhos", "claros dentes", "graça", "sorriso", "boquinha", "elegância", "tagarelice" e "bondade" são leiloados, ao passo que "belleza", "graças", "olhos", cabello", "sorriso", "andar ligeiro", entre outros atributos, são selecionados para oferecer um bolo a uma colega.

O deslocamento desses recursos linguísticos para esses gêneros discursivos não apenas caracteriza esses textos como paródias, como também servem para difundir conceitos normativos, uma vez que as características mencionadas são apresentadas como positivas pois só se leiloa o que tem valor e só se utilizam bons ingredientes para a execução de um bolo de qualidade. Assim, os textos de O Tico-Tico Mundano apresentam uma dupla orientação: o lúdico do jogo de palavras próprio de uma paródia e a difusão de padrões físicos, comportamentais e valorativos.

Lembrando que essa revista tinha como intuito a formação cultural informal de crianças, de modo a normalizar seu comportamento em conformidade com a moral e os "bons costumes" da época, é de se esperar que também os discursos infantis promovam qualidades físicas - sempre em relação ao padrão de beleza europeu caucasiano - e morais desejadas na sociedade em que tais crianças viviam, relativas a um comportamento como obediente e dócil. No entanto, observamos também a renúncia a alguns parâmetros valorativos próprios da ideologia desse período, indicando uma negociação de caráter um tanto confrontador. A exemplo disso, podemos citar o enaltecimento de algumas características para as meninas, 
como "travessa", "deliciosa", "mysteriora", que fogem ao imaginário feminino da época, relacionado a uma figura submissa e dócil ${ }^{45}$.

É possível também que alguns termos sejam empregados pelas crianças de modo irônico, como é o caso de "tagarelice", por exemplo. Dessa maneira, ao invés de visar ao elogio de um colega, os enunciadores podem, em alguns casos, ter como objetivo expor alguma característica tida como negativa. Não podemos afirmar de modo assertivo se todas as características elencadas são, de fato, elogiosas. Porém, independentemente da intenção enunciativa desses textos, podemos observar a proposta de transmissão de valores e normas. Além disso, a possibilidade de que alguns termos sejam enunciados em tom de ironia, pode ser indício de que essas crianças não temiam ser repreendidas por tal atitude, o que aponta para uma maior liberdade discursiva.

Nesse sentido, podemos afirmar que os textos de "Hilf mit!" e de "O Tico-Tico" apontam, para diferentes objetivos argumentativos em termos de negociação. Isso porque, no jornal alemão, os discursos produzidos por crianças possuem como caráter fundamental a concordância com as ideologias sociopolíticas vigentes e, por conta disso, não negociam um confronto com elas, mas sim uma maior visibilidade de atuação política. Já na revista brasileira, essa questão toma um outro rumo, uma vez que se trata de uma negociação num tom mais lúdico. Além disso, ao mesmo tempo em que serve aos mesmos interesses de veiculação do próprio periódico, isto é, à difusão de padrões valorativos a serem seguidos por todos, também vai contra alguns conceitos morais que são negados pelas próprias crianças.

\subsection{Racionalidade, Validade e Valores}

Em conjunto com as questões interacionais, os processos lógicos e racionais desempenham papel fundamental na Argumentação. Para estudar os processos argumentativos, Habermas (2012) se baseia na lógica da argumentação, que se orienta a aspectos internos dos atos de fala, por ele definidas como unidades pragmáticas. Tal perspectiva, também denominada por outros autores como lógica informal, pauta-se em três aspectos fundamentais. São eles: a contestação da lógica dedutiva e da indutiva como modelos de argumentos legítimos; a concepção de que os argumentos podem ser avaliados

\footnotetext{
${ }^{45}$ A atribuição da responsabilidade às mulheres da formação de todas as crianças da nação, discutida no primeiro capítulo, já é um indício desse ideal feminino nessa sociedade, e que as crianças confrontam nos segmentos analisados
} 
não apenas por seu teor retórico, mas também por seus elementos lógicos; e a importância de se voltar para outros textos argumentativos menos formais.

A partir disso, o autor define Argumentação como "uma continuidade reflexiva direcionada, com outros meios, ao ato comunicativo" (HABERMAS, 2012:48). Dessa forma, em sua concepção, a Argumentação corresponde a um processo interacional que orienta o discurso para sua compreensão e persuasão. Outra característica muito importante ressaltada por Habermas diz respeito ao fato de os argumentos se fazerem valer de fundamentos para tornar mais aceitável a conclusão, para a qual eles se orientam. Entendemos que são justamente esses fundamentos que podem revelar os elementos sócio-históricos presentes na argumentação.

Desse modo, o autor propõe o conceito de Racional como uma característica constituída pela Racionalidade - isto é, a competência de raciocínio dos indivíduos - e um saber compartilhado socialmente. Isso significa dizer que o saber compartilhado, validado socialmente, é capaz de conferir um determinado grau de aceitabilidade do argumento de acordo com os valores do grupo em que esse mesmo argumento foi utilizado, garantindo ou não seu efeito persuasivo sobre o auditório selecionado. Nesse sentido, o caráter racional de um determinado argumento poderia ser medido pela adequação do saber tido como premissa, pois, na concepção do autor, "a racionalidade de uma exteriorização [manifestação explícita do saber] depende da confiabilidade do saber nela contido." (HABERMAS, 2012: 31)

Assim, na Alemanha nazista, por exemplo, um discurso permeado por saberes ligados a uma ideologia nacionalista, como o conceito de superioridade da "raça alemã", soará bastante racional para os indivíduos dessa sociedade, uma vez que esse saber é compartilhado por esse grupo. De uma maneira parecida, fazer-se valer desses saberes possibilita a difusão de novas ideias semelhantes a essa mesma ideologia, de modo a criar novos saberes de semelhante valor racional; com isso, a lógica de um saber de caráter nacionalista pode, como foi o caso do surgimento do nazismo, fundar um novo saber simbólico de necessidade de higienização na raça humana, para que fique no planeta apenas a raça considerada superior - a nação alemã. Assim, assumimos com Habermas (2012:40-41) que:

Segundo esse modelo, exteriorizações racionais têm o caráter de ações sensatas, compreensíveis em seu próprio contexto e com as quais o ator se refere a alguma coisa no mundo objetivo. As condições de validade das exteriorizações simbólicas remetem a um saber mental partilhado intersubjetivamente pela comunidade de comunicação. 
Klein (1980), teórico alemão que também segue uma linha retórica de análise da Argumentação, acredita que é nesse uso dos saberes compartilhados a favor da criação de novos saberes válidos que se observa um dos principais processos argumentativos. Segundo o autor "em uma argumentação tenta-se, com a ajuda das validades coletivas, transformar algo questionavelmente coletivo em validamente coletivo" (KLEIN, 1980:19). Entendemos por validades coletivas saberes compartilhados por determinado grupo em uma dada época. Dessa forma, a argumentação propõe-se a justificar os valores difundidos pela sociedade em que se insere, fortalecendo ainda mais a ideia defendida no discurso.

A exemplo disso, em $O$ Tico-Tico Mundano, observamos que os textos ora analisados atentam para a importância normativa de listar e categorizar elementos físicos, morais e comportamentais desejáveis ou não. A orientação direta para esses elementos aponta para a utilização de um saber compartilhado de que é necessário padronizar comportamentos, para a correção de maus hábitos já na infância e, assim, proporcionar às novas gerações - o futuro da nação - uma educação adequada, segundo os valores da época.

Porém, pautando-se nessa orientação, as crianças da revista incluem alguns saberes que não são compartilhados pelos adultos, mas que advém da própria relação entre as crianças sendo resultado da sua observação, como, por exemplo, o enaltecimento da "valentia" de uma garota, expressão geralmente ligada à insubordinação, ou a referência aos "gestos de menina" de um colega, ainda que outras características relacionadas ao padrão de comportamento esperado da época sejam também mencionados - como "graça", termo geralmente utilizado para se referir à delicadeza feminina. Destacamos, a seguir, tais recursos:

Estão em leilão os seguintes meninos da rua Benjamin Constant: Quanto dão pelos gestos de menina do Aranha? pela graça da Ilda? Pelos cabellos lisos da Estela? pela valentia da Jacira? pelos olhos castanhos da Ilda pelas peripécias do Marcolino pela bicicleta do Marcolino pela beleza do Preguinho pelas graças do Levi? pelos passeios de Tedy? pelas shooteiras do Anibal? [Grifo nosso] (T7)

Nos textos selecionados de "Hilf mit!", notamos que os discursos são fundados na validade já aceita de que há uma necessidade de se agir em união com a "raça alemã", com o povo - a referência às canções entoadas pelos garotos, grifada no segmento a seguir, aponta para a importância conferida aos grandes feitos dos tais "serviçais da pátria", apresentados como exemplo às crianças. Esse saber compartilhado é utilizado para fundamentar uma outra ideia, segundo a qual as ações das crianças e de seus coletivos são imprescindíveis para o regime, visando, assim, a justificativa de sua participação nos programas e projetos do governo, como observamos a seguir, em que a referência à "incapacidade" de um adulto 
indica a denúncia do abandono da terra, o que foi solucionado em apenas um dia pelos próprios garotos:

Foi no inverno passado. Nós estávamos contentes e animados com nosso novo abrigo, por nós mesmos decorado, e cantávamos valorosas canções de serviçais da pátria e de viagens. Nosso cantinho era simplesmente primoroso, não se podia falar o contrário. Nós tínhamos um antigo estábulo, o qual fora abandonado há muito tempo por seu dono, devido a sua "incapacidade". Com a ajuda de uma monstruosa quantidade de água, muitos rodapés e papeis de parede cortados, deuse a ele uma aparência habitável. À noite, já estava perfeitamente agradável. [Grifo nosso] $(\mathrm{H} 3)^{46}$.

A partir das validades aceitáveis, apresentadas pelas crianças em seus textos, torna-se possível compreender os valores por eles defendidos. Nessa direção, buscamos em Perelman e Olbrechts-Tyteca (1996 [1958]) a discussão a respeito dos valores difundidos no processo argumentativo. Em "O Tratado da Argumentação", os valores são definidos como recursos destinados a um auditório específico, ou seja, um discurso vinculado a uma sociedade moralista, por exemplo, traz valores também moralistas. Isso ocorre porque "a existência dos valores, como objetos de acordo que possibilitam uma comunhão sobre modos particulados de agir, é vinculada à ideia de multiplicidade dos grupos" (PERELMAN; OLBRECHTSTYTECA, 1996 [1958]: 84). Esses valores, segundo os autores, estão presentes em toda argumentação. São usados para despertar no ouvinte uma maior adesão a determinadas escolhas e, principalmente, para se fazer aprovar por um indivíduo ou um determinado grupo social.

Um recurso argumentativo que possibilita a observação de tais valores é a seleção lexical, destacada por Koch (1993) como um importante elemento para a figura retórica, uma vez que cria imagens como metáforas, oposições, jogos de palavras e, até mesmo, paralelismo rítmico. Segundo a autora, a opção por um termo pode não apenas estar vinculada à questão de falar a mesma língua que o público - isto é, de compartilhar os mesmos valores que seu enunciatário - como também pode proporcionar o efeito argumentativo desejado com maior facilidade que um sinônimo, aumentando, assim,sua adesão ao valor difundido. No que diz respeito aos discursos escritos pelas próprias crianças em O Tico-Tico Mundano, observamos o registro dos seguintes sintagmas nominais, utilizados para qualificar as meninas e os

\footnotetext{
${ }^{46}$ Tradução nossa. No original: "Im vorigen Winter war es. Wie saßen vergnügt unter munter in unserem neuen, selbsttapizierten Heim und fangen pfundige Landsknechts- und Fahrtenlieder. Unser Heim sah einfach knorke aus, da ließ sich nichts gegen sagen. Wir hatten einen alten Pferderstall, der längst von seinen Besitzer wegen 'Unfähigkeit' aufgegeben war, mit Hilfe von ungeheuren Wassermenge, und viele Leiften und geschnorrter Tapete wieder 'menschliches Aussehens' gegeben. Es war verflirt gemütlich an dem Abend."
} 
meninos ${ }^{47}$, coletados dos textos presentes nos periódicos "O Tico-Tico" e "Hilf mit!" selecionados:

${ }^{47}$ Os termos foram agrupados em quadros do tipo "nuvem de palavras", que organizam o tamanho dos elementos nominais a partir da frequência com que ocorrem. Desse modo, quanto maior a expressão, mais frequente ela foi em nossos corpora. 


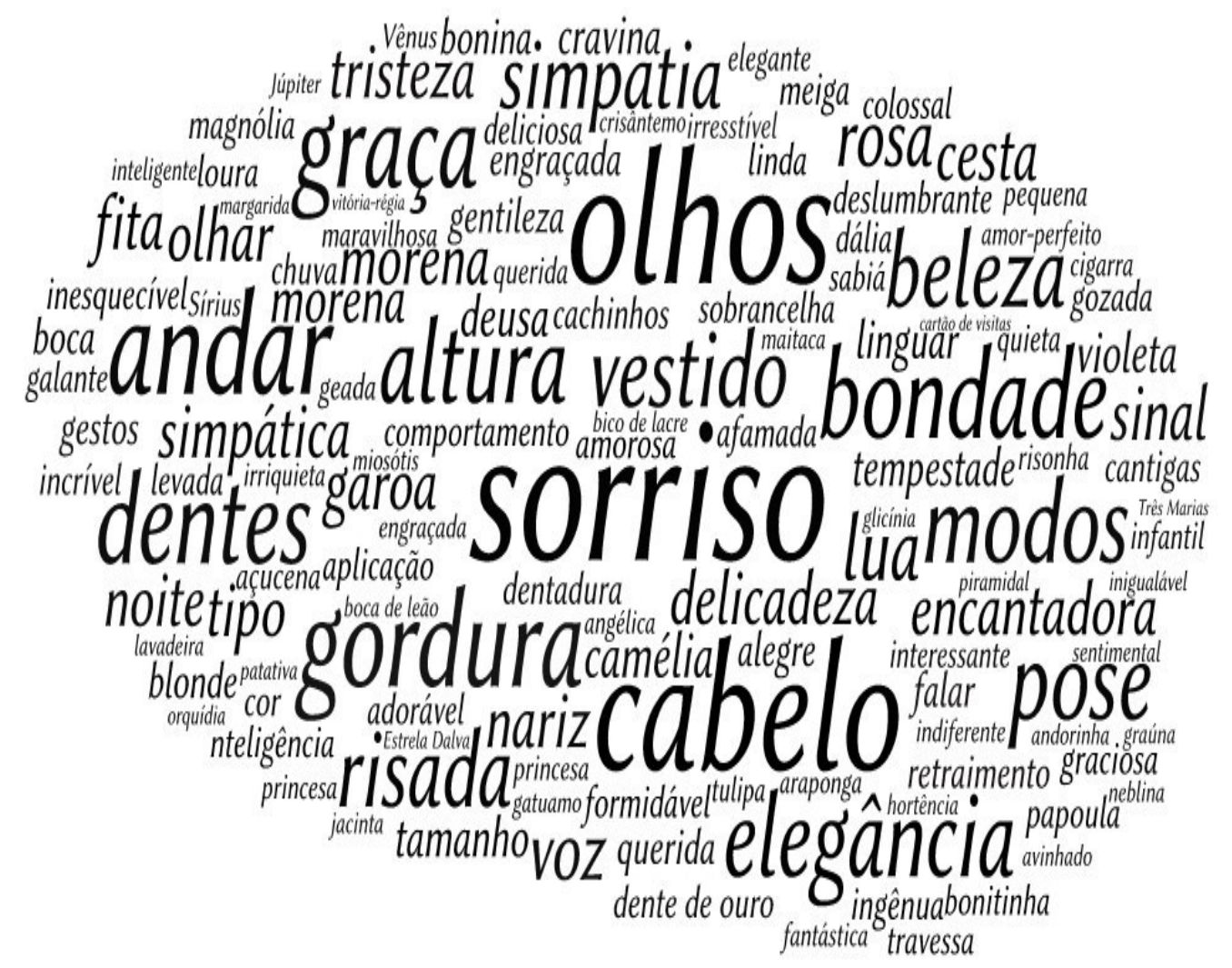

Quadro 3 - Sintagmas nominais atribuídos às meninas

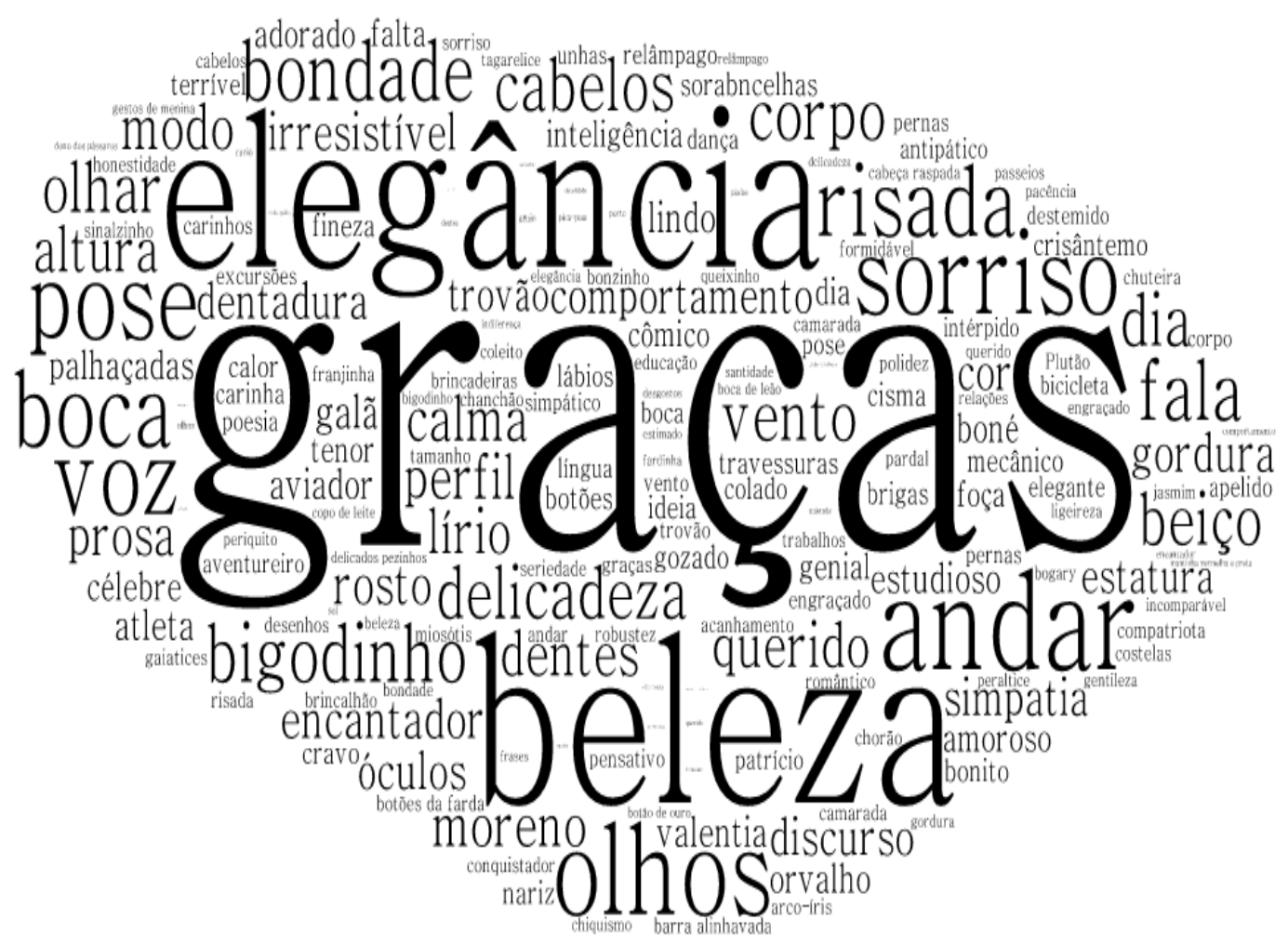

Quadro 4 - Elementos nominais atribuídos aos meninos 
Inicialmente, é interessante notar, no discurso das crianças, o uso de uma grande quantidade de qualificativos e nomes variados. Observamos também que as crianças apresentam uma tendência a utilizar, na maioria dos casos, formas nominais semelhantes para se referirem e caracterizarem seus colegas, fossem eles do gênero feminino ou masculino. Exemplo disso é relacionar tanto meninos quanto meninas ao sucesso escolar, ou a um temperamento mais delicado. No entanto, evidenciamos que, apesar de as crianças romperem com alguns valores impostos de modo muito sutil, elas acabam por manter outros. É o caso das comparações como mecânico e aviador, que só ocorrem com jovens do sexo masculino, sugerindo que as próprias crianças também assumiam que tais cargos só pudessem ser ocupados por homens.

Além disso, nos textos dos leitores, apesar de se elogiarem a delicadeza, o charme e sensibilidade de alguns meninos, outros são sempre caracterizados como viris. As meninas, porém, têm uma caracterização diversa, uma vez que se enaltece sua sensualidade, inteligência, coragem e independência. Compreende-se, dessa forma, que as crianças, dadas como autoras dos textos analisados, apresentam uma tendência de construírem suas identidades de forma individual, ignorando a maior parte das distinções de gênero e rompendo com alguns dos valores sociais da época, porém, os principais valores da sociedade patriarcal em que se inseriam, como a exaltação da virilidade dos homens e a exclusividade de determinadas profissões para pessoas do sexo masculino, foram mantidos.

Em "Hilf mit!", os elementos nominais atribuídos às crianças aparecem com menor frequência. Isso porque os relatos desses textos estão muito mais voltados às ações e à participação dos pequenos em prol do governo do que a qualificá-los. No entanto, os atributos verificados, como destacamos nas imagens abaixo, apontam para uma exaltação da imagem de coletividade e não de uma identidade plural e diversificada das crianças: 


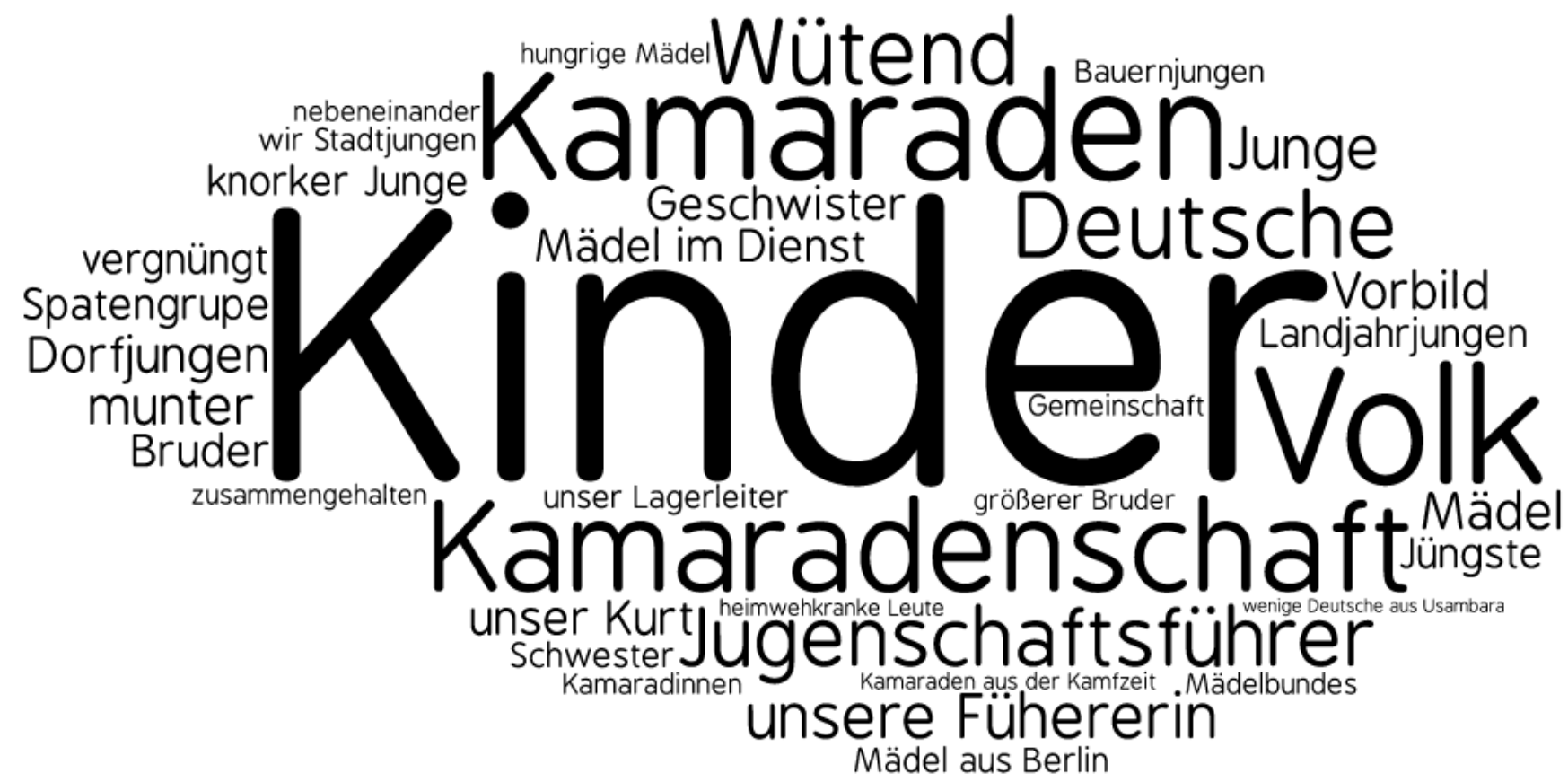

Quadro 5 - Elementos nominais atribuídos às crianças em "Hilf mit!"

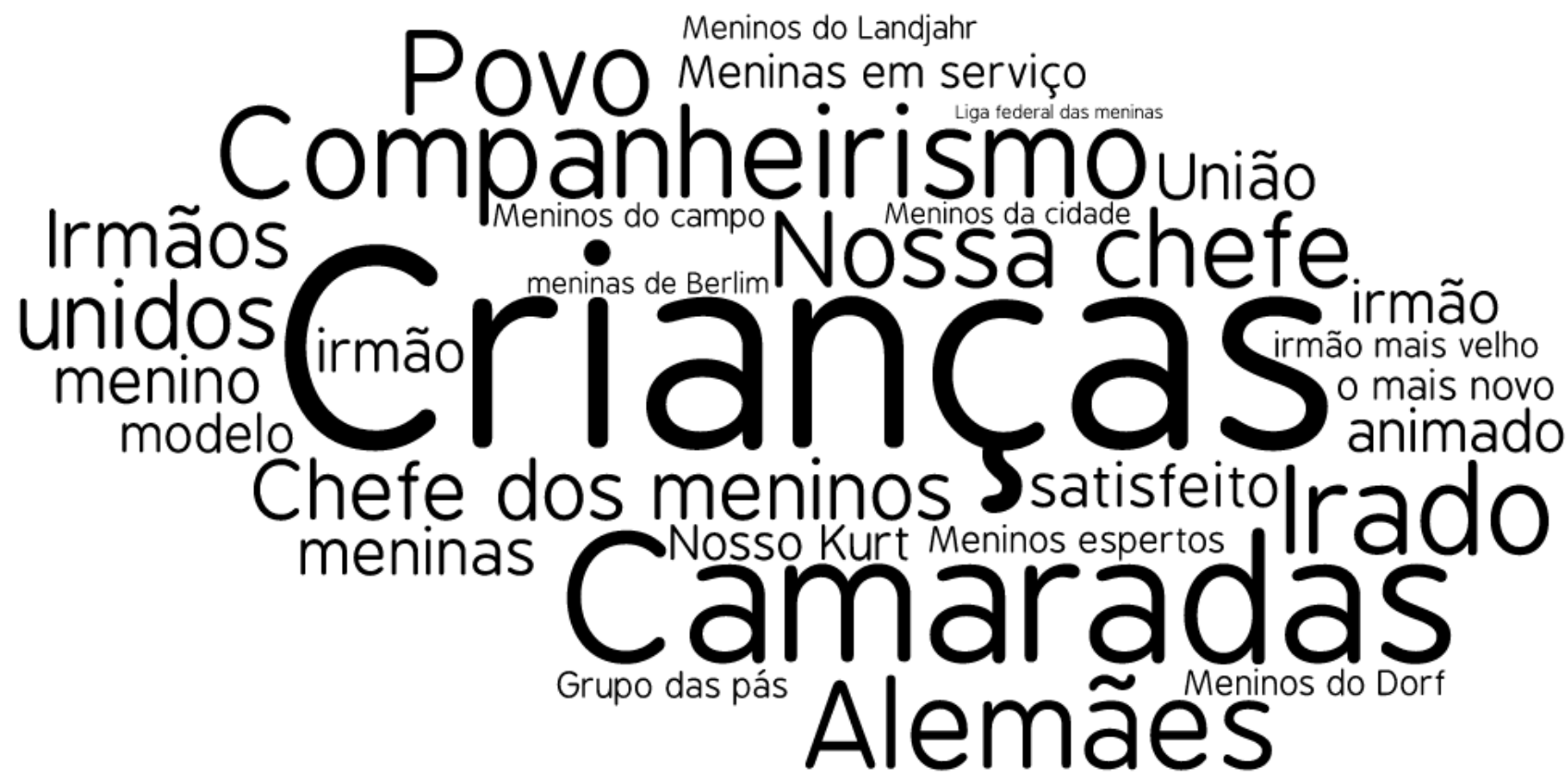

Quadro 6 - Tradução dos elementos nominais atribuídos às crianças em "Hilf mit!" 
O primeiro indício dessa identificação das crianças de modo mais homogêneo e até mesmo massificado pode ser verificado pelo fato de não ser necessário separarmos aqui os elementos nominais atribuídos às meninas daqueles atribuídos aos meninos, uma vez que eram muito parecidos - apesar de termos verificado, no entanto, diferenciação em relação às atividades que cada gênero deveria realizar para participar dos programas e grupos juvenis do regime nazista. Além disso, observamos que os próprios elementos nominais atribuídos às crianças são utilizados no coletivo, ou exprimem uma ideia de união e partilha, como é o caso de termos como "companheirismo", "povo", "alemães", "meninas", "irmãos", "união", que aparecem com maior frequência.

Essa massificação, porém, apresenta-se também de modo hierarquizado entre os grupos, como podemos observar na oposição dos seguintes termos: "irmão mais velho" e "irmão mais novo", "chefe do acampamento", "nossa chefe", "meninos da cidade", "meninos do campo". Essa hierarquização entre os grupos indica que, por trás dessa união da raça, algumas relações de poder eram mantidas, como a supremacia das crianças urbanas em detrimento das rurais, dos mais velhos sobre os mais novos, bem como dos chefes dos grupos juvenis sobre seus outros integrantes.

\subsection{Aproximações e afastamentos entre os corpora em termos de argumentação}

Os resultados observados nos textos atribuídos às crianças no jornal "Hilf mit!" apontam para o deslocamento da disciplina militar para outras atividades como o trabalho rural e o lazer. Essa disciplina também é encontrada na hierarquização que ocorre dentro dos próprios grupos juvenis, estabelecendo-se assim, classes dentro de uma mesma coletividade, de modo que uma criança mais velha e mais experiente fosse tomada como exemplo para as mais novas. Ressaltamos ainda que o auditório previsto desses textos se pautava no recorte racial, isto é, apenas crianças alemãs liam e escreviam para o jornal.

Em relação à temática trabalhada pela revista alemã, observamos que as crianças enunciadoras buscavam enaltecer sua importância para o regime, bem como exaltar o entusiasmo em se reconhecer pertencente ao grupo e à raça, convidando e convocando as demais à participação dos grupos juvenis e dos programas do governo, numa investida de chamada ao estreitamento do vínculo entre os compatriotas e familiares. Outro tema 
verificado diz respeito à necessidade de se enaltecer a cultura alemã em relação às demais, ressaltando processos de colonização fora do território alemão.

Em relação às validades aceitáveis que esses enunciadores buscavam, observamos que os textos se pautavam no saber compartilhado a respeito da necessidade de se unir a raça alemã para, então, defender a validade de sua participação nas ações políticas. O objetivo de tais textos, apontavam, desse modo para a visibilidade de atuação política que estas crianças buscavam alcançar, uma vez que seus relatos se pautavam muito mais por suas ações, do que por suas caracterizações que, por sua vez, ocorriam de modo bastante massificado.

Em "O Tico-Tico", constatamos inicialmente uma manutenção da estrutura em todos os textos, o que nos permitiu observar todos eles em conjunto, ressaltando características mais ou menos frequentes ao longo das edições. Além disso, as imagens veiculadas bem como os enunciados de autoria presumidamente infantil apontam para que tais textos fossem destinados a crianças de maior poder aquisitivo e de repertório cultural mais erudito e diversificado. Isso nos indica que o direcionamento ao público desta revista se baseava num recorte sociocultural e econômico, e não apenas político-racial como acontecia em "Hilf mit!". É certo que, como discutido no primeiro capítulo, tais questões também estão bastante atreladas até hoje, em nosso país, a características raciais, porém, nos textos analisados no corpus alemão, não se verificaram exclusões de público alvo quanto a questões socioeconômicas, uma vez que seu objetivo era de unir toda a "raça alemã", ainda que se mantendo algumas hierarquias desse caráter.

No que diz respeito às validades aceitáveis observadas nos textos da revista brasileira, constatamos que os enunciadores se faziam valer de uma validade coletiva baseada na necessidade de se difundirem valores e normas comportamentais para apresentar outros valores conflitantes com os aceitos pela sociedade da época. Desse modo, observamos que, ao mesmo tempo em que algumas normas eram mantidas e propagadas pelas crianças, outras eram rompidas. A exemplo disso, podemos citar a exaltação da virilidade masculina consoante com os valores da época - ao lado do elogio da sensualidade de meninas considerado inapropriado pelos adultos. Esses valores e normas eram difundidos pelos jovens enunciadores a partir do uso da paráfrase de outros textos, o que garantia a esses enunciados uma negociação de caráter confrontador com alguns valores sociais da época num tom bastante lúdico.

Os dois periódicos também apresentaram semelhanças bastante interessantes no que se refere à questão da autoria dos textos, uma vez que, em ambas as situações, os enunciados atribuídos a crianças aparecem quase sempre juntos a enunciados escritos pelos editores dos 
periódicos e, no caso específico do jornal alemão, até mesmo por Adolf Hitler - porém, editados em trechos pelo próprio jornal. Isso indica que, ainda que os textos analisados tenham sido de fato escritos apenas por crianças - isto é, desconsiderando também quaisquer possíveis edições -, o espaço conferido a elas era ainda bastante cerceado pela voz do adulto.

Outra característica em comum entre os corpora que merece destaque diz respeito à distinção bastante clara entre os gêneros. Nos textos da revista "O Tico-Tico", essa diferenciação se dá pelos diferentes elementos nominais atribuídos às meninas e aos meninos respectivamente, o que inclusive levou à necessidade de se criarem dois quadros de palavras distintos para cada grupo. Já em "Hilf mit!", essa questão foi observada na referência às atividades destinadas a cada grupo. No entanto, em ambos os casos, essa distinção entre os gêneros serve à manutenção de relações de poder entre homens e mulheres, já observada desde a infância.

Compreendemos, desse modo, que observar os processos de significação dos valores argumentativos nos textos pode nos indicar outras questões, como o grau de influência exercido pelo momento político no processo de composição dos discursos e o modo com que os textos dados como formulados pelas crianças apresentavam marcas da constituição de suas próprias identidades dentro dessas questões contextuais. Tendo isso em vista, o capítulo que segue será voltado justamente para o discurso político e construção da identidade. 


\section{CAPÍTULO III - IDEOLOGIA E IDENTIDADE}

Propomos, no presente capítulo, um estudo das noções de ideologia apresentadas por autores da Análise Crítica do Discurso, como Wadok (2004), Fairclough (2001) e van Dijk (2000) para, em seguida, discutirmos a respeito dos conceitos de Discurso Autoritário e Discurso Interiormente Persuasivo. Por fim, observamos os dados obtidos a partir das análises com base nos conceitos de Moita Lopes (2002), Jungwirth (2007) e Keupp (1999) em termos de construção de identidade no discurso.

\subsection{Ideologia no Discurso}

Nesta Dissertação tomamos o conceito de ideologia conforme proposto pela Análise Crítica do Discurso, área de estudos discursivos voltada às manifestações do poder presentes na linguagem, observando esta como um instrumento de força social e de dominação, utilizado para a manutenção das relações de poder nos discursos. A ideologia nessa perspectiva é, então, entendida como "formas e processos sociais dentro dos quais, e através dos quais, formas simbólicas circulam no mundo social", conforme afirma Wodak (2004:13).

De acordo com a estudiosa da $\mathrm{ACD}$, as ideologias legitimam estruturas de dominação em grupos detentores de poder, fazendo dela instrumento de produção de significados mascarados, que se apresentam como dados ou representações da verdade. (WODAK, 2004). Desse modo, na concepção da autora, decifrar as ideologias é fundamental para a desmitificação de discursos institucionalizados e, com isso, desconstruir relações de poder entre os indivíduos.

Segundo Fairclough (2001:119), a ideologia pode ser entendida como "uma orientação acumulada e naturalizada que é construída nas normas e nas convenções, como também um trabalho atual de naturalização e desnaturalização de tais orientações nos eventos discursivos". Isto é, da mesma maneira em que é naturalizada, a ideologia também apresenta um caráter de transformação, o que permite a ela a remodelação de práticas discursivas, redefinindo e até mesmo desnaturalizando relações de dominação.

Esse processo de subversão das relações de poder ocorre, conforme o autor, na medida em que os indivíduos se posicionam criticamente diante de práticas discursivas, de maneira a reestruturar as práticas que antes lhe eram impostas. Isso significa dizer que, na medida em 
que os indivíduos superam determinadas ideologias e valores a elas vinculados, superam também as relações de dominação que se pautam nessas mesmas ideologias.

Van Dijk (2000), também teórico da ACD, define a ideologia como um sistema de crenças. Isto é, para ele não se trata do caráter opressivo que esses sistemas podem ou não apresentar, mas sim de se compreender tais aspectos enquanto base de práticas sociais. Em suas palavras: "Ideologias são crenças fundamentais de um grupo e seus membros" ${ }^{48}$ (VAN DIJK, 2000:6). Com base nas concepções de ideologia ora discutidas, passamos à observação do discurso citado enquanto categoria de análise, como proposto por Bakhtin (2015 [1930]), buscando compreender processos de formação ideológica a partir do modo que o enunciador reproduz, com suas próprias palavras, o discurso de outrem.

Segundo o autor, essas crenças que estruturam as ideologias se estabelecem nos planos cognitivo e social, ambos inscritos na língua. No primeiro plano, a ideologia se dá a partir do armazenamento de conhecimentos amplos e abstratos de um modo mais dinâmico e durável, possibilitando a fundação de representações sociais que se fixam na memória de longo prazo dos indivíduos. A partir dessas referências, estabelecidas linguisticamente, a ideologia se volta para seu plano social, à medida em que essas memórias passam a comportar características que legitimam e organizam modelos mentais como conhecimentos de grupo, valores e comportamentos esperados. Desse modo, quando os indivíduos constroem um discurso, selecionam-se modelos mentais pré-estabelecidos, ou seja, ideologias, de modo a orientar valores e manipular comportamentos e até mesmo a interpretação do próprio discurso em si.

\subsubsection{O discurso Autoritário alemão}

Em “Teoria do Romance I", Bakhtin (2015 [1930]) discute a respeito de um tipo específico da palavra de outrem: aquelas que são citadas, porém com as próprias palavras de quem as relata. O autor observa que todas as interações verbais são permeadas por discursos alheios e, muitas vezes, eles não chegam a ser citados propriamente, mas as ideias desses discursos são incorporadas à enunciação de quem fala ou escreve. A reflexão em relação a esse posicionamento levou-nos a pensar em torno da possibilidade de tomarmos a citação como categoria de análise. Justifica-se ainda essa tomada de decisão a partir de termos observado a possibilidade de se compreender, a partir do modo que o discurso do outro

\footnotetext{
${ }^{48}$ Tradução nossa. No original: "Ideoligies are the fundamental beliefs of a group and its members."
} 
aparece citado, o posicionamento do enunciador em relação à própria citação. Nesse sentido, entendemos que o discurso citado revela características importantes em termos de formação ideológica, como afirma o autor:

Ganha um significado ainda mais profundo e substancial a diretriz voltada para a assimilação do discurso do outro no processo de formação ideológica do homem, na própria acepção do termo. Aqui, o discurso do outro já não atua como informação, instrução, regras, modelos, etc.; ele procura determinar os próprios fundamentos da nossa relação ideológica com o mundo e do nosso comportamento, atua aqui como um discurso autoritário e como discurso interiormente persuasivo ${ }^{49}$. (BAKHTIN, 2015[1930]: 136)

Segundo o estudioso, essa primeira forma de enunciação - o discurso autoritário - está profundamente ligada à religião, à política, à moral e à palavra dos pais, professores e adultos em geral. Ela se relaciona com figuras de autoridades já estabelecidas e reconhecidas socialmente e, por conta disso, não necessitam lutar por espaço de adesão. Trata-se de uma ideologia imposta aos sujeitos. "O discurso autoritário exige de nossa parte um reconhecimento incondicional e nunca um domínio livre e uma assimilação com meu próprio discurso. [...] Ele se integrou de forma indissolúvel à autoridade externa [...] - persiste e cai junto com ela" (BAKHTIN [1930] 2015:137-138).

Tal condição do discurso autoritário faz que ele assuma um caráter rígido semanticamente, além de exigir total reconhecimento ideológico por parte dos enunciatários. Não se trata da compreensão da ideia de outrem, mas sim da aceitação de uma autoridade já estabelecida anteriormente, o que dificulta esforços num sentido de questionamento de tais forças político, moral, religiosa e socialmente mais fortes.

Em relação a aspectos próprios do discurso autoritário presentes nos enunciados das crianças de "Hilf mit", observamos a importância dada à união dos pares evidenciada pelos elementos linguísticos presentes no seguinte enunciado:

$$
\text { “[...] Somos todos alemães - um único povo. [...]” }(\mathrm{H} 2)^{50} \text {. }
$$

Entendemos tratar-se de uma tentativa de apagamento da subjetividade dos cidadãos, no sentido de não permitir que cada um tivesse características próprias, uma vez que a união nacionalista, assim como ocorreu no governo de Hitler, presume que todos correspondam às mesmas características, a um mesmo sistema de normas identitárias. Como destacou Fischer

\footnotetext{
${ }^{49}$ No próximo segmento do trabalho, será observada a questão do discurso interiormente persuasivo, pois é encontrado de modo muito mais visível na revista brasileira. Por ora, será analisado apenas o discurso autoritário.

${ }^{50}$ Tradução nossa. No original: "[...] Wir sind alle Deutsche - ein eigenes Volk. [...]"
} 
(1995), o sentimento de uma identidade nacional coesa exerceu um papel fundamental durante o regime nazista, pois permitiu, sobretudo, a exclusão daqueles que não correspondiam aos padrões do que era considerado "povo alemão". Nesse sentido, unir-se ao seu semelhante era quase um dever moral, era se identificar como um cidadão pertencente ao grupo hegemônico, como observamos em "somos todas uma só" e "devemos estar ao lado do nosso povo", no excerto a seguir:

[...] Aqui nós nos sentamos uma ao lado da outra, meninas de todas as origens do nosso povo, meninas do leste, norte, sul e oeste de Berlim, e somos todas uma só: meninas alemãs, que na juventude hitlerista, com atitude e detenção devemos estar ao lado do nosso povo. [grifo nosso] $(\mathrm{H} 2)^{51}$

O sentimento de união é também a motivação dos enunciadores para seus serviços prestados e esse espírito de companheirismo está sempre muito presente no discurso nazista. No seguinte excerto, a expressão "todo alemão" pode ser aludida a uma convocação estendida a todos os membros da raça alemã, independentemente do gênero ou da idade.

[...] todo alemão, seja homem ou mulher, menino ou menina, deve apoiar essa obra [Brigada de Inverno] do Führer [grifo nosso] (H3). [... $]^{52}$

O apoio ao programa da Brigada de Inverno é também necessário por estar diretamente associado à figura de autoridade maior de todo o regime, o Führer. Outra questão importante a ser destacada, diz respeito ao fato de que o espírito de companheirismo entre os semelhantes, ou seja, entre aqueles considerados pertencentes ao povo alemão deveria ser, para as crianças, mais importante que a própria esfera escolar:

[...] A escola, a fábrica e o escritório estão esquecidos, pois à frente há uma semana de companheirismo, uma semana cheia de esporte e formação espiritual. [grifo nosso] $(\mathrm{H} 2)^{53}$.

Essa formulação permite observar que, para o enunciador, a autoridade do governo, sempre vinculada à figura de Hitler, colocava-se hierarquicamente acima de outras esferas também baseadas no discurso de autoridade, como a escola. Podemos compreender que os ideais ligados à autoridade do Führer estão à frente de outros ideais que permeavam a

\footnotetext{
51 Tradução nossa. No original: "[...] Da sitzen wir nebeneinander, Mädel aus allen Schichten unseres Volkes, Mädel aus dem Osten, Norden, Süden und Westen Berlins, und sind doch nur eins: deutsche Mädel, die in der Hitlerjugend ihrem Volke mit Tat und Einsatz zur Seite stehen sollen."

52 Tradução nossa. No original: "[...] jeder Deutsche, ob Mann oder Frau, ob Junge oder Mädel, dieses Abfallwerk des Führers unterstützen müsse. [...]"

53 Tradução nossa. No original: "Vergessen sind Schule, Fabrik, und Büro; denn vor uns liegt eine Woche Kameradschaft, eine Woche voller Sport und geistiger Schulung.
} 
sociedade. A própria escolha do termo Führer para denominar o líder da nação, já é um indício dessa posição, uma vez que seu significado exprime a ideia de condutor, ou daquele que está à frente de um grupo, dirigindo-o a um objetivo. Observamos também nos enunciados a menção recorrente à figura de uma autoridade hierarquicamente inferior ao chefe de estado - os pais e os chefes de acampamento. Trata-se de pessoas que, em algum momento participaram da instrução a respeito dos preceitos em que se pautava a ideologia nazista, como no trecho destacado a seguir, no qual a chefe do acampamento relata sua participação no início do movimento pró-nazista:

[...] 'Nós permanecemos juntos', dissera Gerda, 'para que nosso povo pudesse se tornar forte e unido novamente. Nós não temíamos ninguém e sempre permanecíamos unidos, na alegria e na tristeza'. [...] $(\mathrm{H} 2)^{54}$

Além disso, na fala de Gerda, selecionou-se o sintagma verbal "permanecer" indicativo de conservação - que se repete ao final do enunciado para que se reforce a ideia que se quer acreditada. O "permanecer junto" comporta a crença da força e da união que combate o temo de qualquer ordem - posição extremamente ideológica.

É possível observar, na fala de Gerda, a chefe do acampamento das meninas, a mesma característica do discurso autoritário nazista presente na voz da autora da carta Meninas no Acampamento. Ela, enquanto uma pessoa mais experiente em termos de apoio ao Partido Nazista, atua como instrutora das demais garotas. Logo em seguida, a enunciadora da carta a complementa, demonstrando total adesão a essa ideologia propagada, ao lamentar seu tardio apoio ao governo e o desejo de recuperar o tempo de mobilização política perdido, como nos segmentos destacados:

“[...] Nós, porém, que só depois encontramos o reconhecimento ao poder de Adolf Hitler, queremos tomar nossos camaradas dos tempos de luta como modelo e, assim como eles anteriormente, permanecermos juntos com os outros em companheirismo. [...]" [Grifo nosso] $(\mathrm{H} 2)^{55}$

A figura de autoridade também aparece representada pelo pai, como no excerto de Nós queremos colaborar, em que o filho aprende um pouco sobre o conceito de socialismo empregado pelo nazismo. Observamos que o pai, hierarquicamente superior ao filho,

\footnotetext{
${ }^{54}$ Tradução nossa. No original: "[...] 'Wir haben damals zusammmengestanden', hatte Gerda gesagt, 'damit unser Volk wieder stark und einig werden sollte. Wir haben uns vor niemand gefürchtet und stets zusammengehalten in Freud und Leid.' [...]"

${ }^{55}$ Tradução nossa. No original: "[...] Wir aber, die wir erst nach der Machtübernahme zu Adolf Hitler fanden, wollen unsere Kameraden aus der Kampfzeit zum Vorbild nehmen und, so wie sie damals auch heute mit den anderen Kameradschaftlich zusammenhalten. [...]"
} 
submete-se à ideologia imposta pelo governo. Sua fala também se caracteriza como um discurso autoritário, na medida em que enaltece a necessidade de todos se unirem em prol da melhoria do país, conforme podemos observar a seguir na referência aos necessários "sacrifícios com o compatriota alemão":

'Olha só, rapaz,' ele [o pai] me disse, 'isto é que é socialismo de fato. Não fazer doações e dar esmolas, mas sim dividir os sacrifícios com o compatriota alemão. Se todos os seus jovens camaradas pensarem assim e agirem como você, a Alemanha se tornará melhor.'[grifo nosso] (H3). ${ }^{56}$

Observa-se, com isso, que a doutrinação à qual as crianças de "Hilf mit!" são submetidas não ocorria apenas a partir da leitura do jornal em si. Ela estava presente em diversas esferas dessa sociedade alemã. A família e o acampamento eram apenas alguns dos espaços em que esse discurso autoritário também circulava. Esse discurso, porém, não circulava apenas, ele era, sobretudo, ensinado, como observamos em destaque no segmento, em que o acampamento constitui um importante espaço em que tais ideologias eram difundidas:

\begin{abstract}
Algumas de nós já aprenderam a entender no acampamento porque estão em nossa Liga Federativa de Meninas e o que nós queremos. Em comunidade com outras, elas ficam agora conscientes em relação à bandeira e flâmula da nossa liga, enquanto meninas em serviço da Alemanha. [grifo $\operatorname{nosso}](\mathrm{H} 2)^{57}$
\end{abstract}

O trecho anterior leva-nos a compreender que o desejo de se estar em comunhão com os compatriotas e servir à pátria era algo ensinado às crianças em diversas esferas da sociedade da época. Isto é, o regime político vigente se articulava de tal modo que esse discurso autoritário era veiculado e ensinado em praticamente todos os espaços da vida social da população. É válido ressaltar que o pouco, ou talvez inexistente espaço para o confrontamento de ideias opostas ao regime político hegemônico, instaurado pelo próprio controle midiático e censura do governo nazista, impediam a veiculação de outros discursos ou de outros pontos de vista em relação ao pensamento nazista.

Não estamos, entretanto, afirmando que a rigidez do governo totalitário tenha extinguido outras ideologias; elas, na verdade não podiam ser expressas, o que resulta no fato

\footnotetext{
56 Tradução nossa. No original: " 'Sieh mal, Junge', hat er zu mir gesagt, 'das ist Sozialismus der Tat; nicht Spenden oder Almosen geben sozialistisch, sondern mit den Volksgenossen teilen und opfern. Wenn alle deine jungen Kamaraden so denken und handeln wie du, dann wird es bei uns in Deutschland bald wieder besser werden."

57 Tradução nossa. No original: "Manch eine von uns hat erst hier im Lager verstehen gelernt, wozu sie in unserem Mädelbund ist und was wir wollen. In Gemeinschaft mit den anderen steht nunmehr auch sie bewußt zu den Fahnen und Wimpeln unseres Bundes als Mädel im Dienst für Deutschland."
} 
de não poderem ser localizadas nos enunciados que circulavam nesse contexto específico. Se, por um lado, o discurso de crianças no jornal alemão "Hilf mit!" é permeado por características próprias do discurso autoritário, o mesmo não ocorre na revista brasileira "O Tico-Tico", como discutimos a seguir.

\subsubsection{O Discurso Interiormente Persuasivo no Brasil}

A concepção de Discurso Interiormente Persuasivo, expressão tomada de Bakhtin (2015 [1930]) também se configura como um discurso citado por outrem, porém, apesar de haver referência à fala de um terceiro, este não é colocado como uma autoridade e, portanto, há maior liberdade por parte dos enunciadores para participarem e se colocarem ideologicamente em seu discurso, o que confere a esses enunciados um caráter inacabado, pois estão sempre em processo de ressignificação e reelaboração. O discurso interiormente persuasivo não se ancora na voz de uma autoridade, por isso ele é encontrado em situações nas quais há maior abertura de espaço para a individualidade do enunciador, isto é, nos casos em que o autor reflete a respeito daquilo que cita, tornando o enunciado do outro uma palavra autônoma sua e se apropriando de seu próprio discurso.

Segundo o autor, nas diversas situações comunicativas, entramos em contato com vários discursos interiormente persuasivos que se colocam em tensão entre si. E é justamente nessa tensão que se dá a formação ideológica dos sujeitos, pois nesses ambientes discursivos, entramos em contato com diferentes pontos de vista. O autor, a respeito disso afirma: "A estrutura semântica do discurso interiormente persuasivo não é concluída, é aberta, e em cada novo contexto dialogante é capaz de revelar possibilidades sempre novas" (BAKHTIN, 2015:140). E com essa abertura de possibilidades semânticas é possível encontrar os mais diversos gêneros de discurso.

É o caso dos enunciados produzidos por crianças em O Tico-Tico Mundano, seção da revista reservada para informes do cotidiano infantil, muito semelhante a uma coluna social. Como foi evidenciado no primeiro capítulo, entendemos que as crianças se faziam valer dessa seção para enumerar qualidades e defeitos de seus colegas, utilizando, para isso, uma estrutura discursiva muito semelhante à dos textos dos adultos, como observamos a seguir:

EM LEILÃO

Estão em leilão as seguintes senhoritas e rapazes residentes no Meyer: Quanto dão pela altura de Alda? pelo sorriso da Dilma? pela bondade de Cremilda? pelos modos da Joanninha? pela tristeza da Lourdes? pela elegancia da Jújú? pela sympathia da Franciscquinha? e quanto dão pela 
querida leiloeira? (T1).

No excerto anterior, observamos que o enunciador cria um anúncio de leilão, gênero discursivo comum em colunas sociais. No entanto, esse texto totalmente lúdico tem por intuito enaltecer as qualidades dos colegas do autor e não de anunciar um leilão de fato. A apresentação de tais qualificativos - já observados na seção 2.3.1 - apontam para uma provável importância conferida a determinadas características e à necessidade de enaltecê-las, sobretudo por conta do projeto político então vigente de oferecer, também pela revista "O Tico-Tico" - como observado no primeiro capítulo -, uma educação informal que proporcionasse às crianças uma formação em termos de valores morais e comportamentais. Algo semelhante acontece nos avisos intitulados "Em Viagem":

\section{EM VIAGEM...}

O avião "Meteóro" saiu de S. Critóvão rumo a Hollywood. Era aviador Zézinho e o mecanico José. Passageiros: Véra, Carlos, Elvira e Ruth. Durante o Percurso de viagem fomos surpreendidos pelos seguintes meteóros: Celia, a garôa; Claudio, o vento; Marilia, a tempestade; Olavo, o relampago. Indo em seguida aterrissar em Hollywood onde vários astros cinematográficos já esperavam ansiosos. - J. F. C. (T7)

Nesse segmento, o informe a respeito de uma viagem realizada supostamente por alguém de prestígio social se apresenta como uma brincadeira, um faz-de-conta. Em ambos os casos, é possível afirmar que ocorre uma apropriação discursiva dos avisos das colunas sociais, no sentido de que tais gêneros são incorporados e recriados dentro do universo infantil. Até certo ponto, os enunciadores subvertem os gêneros de modo a ressignificá-los num viés bastante lúdico, de modo a enaltecerem seus colegas e amigos. Porém, entendemos que o principal caráter de apropriação discursiva encontrado nos textos selecionados, relacionados diretamente à noção de discurso interiormente persuasivo, diz respeito ao conteúdo ideológico veiculado nos enunciados produzidos por crianças. Nos anúncios intitulados "No cinema", essa questão fica bastanteevidente, conforme destacamos nos trechos a seguir:

NO CINEMA...

Para fazer um film contractei as seguintes meninas e meninos da rua José Bonifácio: Vanda, a loura Constance Bennett; Yeda, a graciosa Anita Page; Lygia, a sympathica Rosita Moreno; Aida, a linda Jannette MacDonald; Marietinha, a ingenua Sylvia Sydney; Valma, a alegre Clara Bow; Maria Seli, a fascinante Norma Shearer; Rachel, a inesquecivel Rachel Torres; Georgina, a adoravel Joan Crawford; Jorge, o nosso querido patricio Raul Roulien; Fernando, o genial John Barrymore; Henriquinho, o romantic 
Ramon Novarro; Walter, o engraçado Buster Keaton; Luiz, o athleta Philippe Holmes; Urbano, o formidavel Etam Lawrell, e eu a diretora - I. C. B. [grifo nosso] (T1).

Nessa suposta divulgação de um filme em cartaz, são anunciadas as qualidades de crianças de uma dada vizinhança. No entanto, as características destacadas no segmento anterior acabam por qualificar as meninas de um modo um tanto incomum para a época, uma vez que são descritas como sensuais - fascinante, inesquecível - ou atribui a si mesma um cargo de diretora de cinema, geralmente ocupado apenas por homens. Também foram, é claro, enaltecidas outras características femininas, por sua vez, em concordância com a ideologia da época, como é o caso dos termos graciosa,sympathica, adoravel e alegre.

Ressaltamos ainda que, conforme discutimos no Capítulo I desta Dissertação, a revista em questão trazia uma grande diversidade de gêneros discursivos em suas edições, como narrativas, anúncios publicitários, seção de curiosidades, seções de passatempo, relatos de viagens, romances, poemas, histórias ilustradas, tirinhas (Mickey, Poopey, Felix e Faustina), e a seção de colunas sociais. Sendo assim, é possível observarmos que os enunciados de suposta autoria infantil de "O Tico-Tico" reproduzem um discurso voltado à importância da formação moral, cultural e comportamental, demonstrando, assim, concordância com os discursos veiculados socialmente e em diversas esferas a respeito da renovação social do país a partir da educação das crianças, nessa nova fase da democracia brasileira do Governo Constituinte, marcada por um intenso nacionalismo e crença na infância como futuro da nação. Porém, os mesmos discursos produzidos por crianças - como discutido no segundo capítulo - apresentam um entrelaçamento de gêneros discursivos, constituindo, assim, paródias de enunciados produzidos por adultos. Nesse entrelaçamento discursivo, surgem também referências a outros repertórios culturais que não circulam no periódico em questão, como é o caso do cinema, por exemplo. Além disso, os valores difundidos pelas crianças em tais enunciados vão contra algumas das validades coletivas já aceitas entre o público adulto - como a sensualidade, valentia e inteligência em meninas de acordo com o que foi apresentado no capítulo anterior -, indicando novamente a apropriação discursiva por parte desses pequenos enunciadores do discurso político e ideológico que circulava essa época, o que provavelmente pode decorrer do amplo repertório cultural a elas oferecido.

Observamos, desse modo, que o Discurso Interiormente Persuasivo se dá na tensão entre diversos discursos de diferentes ideologias, conforme proposto por Bakhtin (2015 [1930]). Sendo assim, as crianças que escreviam para o "Tico-Tico" estavam em contato com vários discursos e gêneros discursivos diversos a partir do próprio periódico em si, do 
discurso escolar e do cinema, por exemplo. E, na luta entre as diversas ideologias circulantes nesses discursos, surge o Discurso Interiormente Persuasivo das crianças em $O$ Tico-Tico Mundano.

\subsubsection{Correlação entre os periódicos}

Os resultados observados apontam para uma grande diferença em termos de apropriação discursiva nos dois periódicos, uma vez que os enunciados produzidos por crianças em "Hilf mit!" se apresentam muito ligados à ideologia nazista e, sobretudo, à figura de poder do Führer. Em contrapartida, os enunciados em "O Tico-Tico" de autoria infantil não são caracterizados por alusão a uma autoridade ou a uma única ideologia em específico; eles se caracterizam justamente pela pluralidade tanto linguística quanto ideológica. É certo que não podemos esquecer outras características já mencionados no primeiro capítulo - em relação a suas questões midiáticas e seu contexto sociopolítico - e que contribuem muito para as diferentes produções discursivas encontradas nos dois periódicos. Isto é, o fato de "O TicoTico" se caracterizar como uma revista mais lúdica, informal e que apresenta diversos gêneros discursivos contribui muito para essa maior apropriação discursiva. Importa ressaltar ainda que os próprios editores da revista, sobretudo Manoel Bonfim - conforme discutido no primeiro capítulo - , propunham-se a uma formação cultural das crianças, futuros cidadãos do nação, o que já fazia parte também do projeto político de eugenia social no Brasil dessa época. Essa proposta era um tanto diferente do Nazismo alemão que, apesar de também se preocupar com uma eugenia - porém, racial -, tinha como principal intuito uma unidade ideológica, por isso observamos o pouco espaço oferecido pelo governo e suas mídias para a circulação de outros discursos.

Desse modo, podemos observar uma forte relação entre os aspectos politicossociais com a estrutura argumentativa dos enunciados analisados, tanto em termos midiáticos, quanto em termos ideológicos, conforme apresentado no terceiro e último tópico deste capítulo. Notamos, sobretudo, que a criança enquanto enunciadora, caracteriza-se, nesses discursos, de um modo bastante ativo, apesar de ser muito influenciada pelo meio em que vive, como é usual. 


\subsection{Identidade no Discurso}

A abordagem dos estudos identitários no meio acadêmico brasileiro permite localizar em Grigoletto $^{58}(2006: 15)$ a importância de se situar os estudos de identidade dentro dos estudos discursivos, de modo a se considerar também os aspectos socioculturais em que as identidades se constroem. De acordo com a autora, "entende-se que as identidades são formadas na relação inescapável e necessária com a alteridade”. Daí a ideia de estudá-la no âmbito discursivo. Ora, sendo o discurso um fenômeno linguístico que se constrói na interação entre enunciador e enunciatário, é muito natural compreender que a construção da identidade dos indivíduos por ele revelada também esteja permeada por tal dialogismo. Assim, na atenção à alteridade, às características do outro, são construídas também as identidades no discurso.

Tal relação com a alteridade é tratada também por Oliveira (2007:22), que compreende o papel de constituição identitária realizado por ações intersubjetivas, em que a alteridade também serve de modelo e de parâmetro aos enunciadores para a construção de suas identidades de modo a se adequar a cada situação e interlocutor. Em suas palavras, o estudioso de identidade deve se ater ao

[...] fato de que o ser humano é um ser de linguagem, o que significa compreender que a constituição de identidades realiza-se pelas e nas práticas discursivas, através de realizações intersubjetivas, portanto, considerando que a alteridade assume natureza constitutiva de tais processos.

Munanga (1996:17), voltando-se também para uma perspectiva sociológica da identidade, afirma que "qualquer grupo humano, através de seu sistema axiológico, sempre selecionou alguns aspectos pertinentes de sua cultura para definir-se em contraposição ao alheio." De acordo com a autora, a construção da identidade pode ocorrer de dois modos diferentes: pela autoidentificação, ou seja, quando se trata da definição de si mesmo, ou pela atribuição de identidade, relativa à definição de um outro. Uma das principais funções de tais definições (de si e do outro) consiste em manipular ideologicamente um determinado grupo, a partir de interesses políticos, sociais, econômicos, entre outros. Sendo assim, compreende-se que a identidade se constitui num jogo dialógico entre os participantes envolvidos numa determinada situação. Dessa forma, quando, por exemplo, dois indivíduos interagem entre si, ambos constroem, no processo, sua própria identidade e a do outro.

\footnotetext{
${ }^{58}$ Tomamos aqui apenas a definição de identidade proposta pela autora e não todo seu aparato teórico, dado que este corresponde à $\mathrm{AD}$ francesa, linha de estudos discursivos diferente da nossa pesquisa.
} 
Desse modo, compreendemos que uma das principais características interacionais do discurso - e também da identidade - é a negociação de papeis entre enunciador e enunciatário, que constroem em conjunto as representações um do outro, bem como as suas próprias imagens. Nesse sentido, buscamos em Aquino e Luques (2012:136) a noção de que tais modelos se constroem e se modificam discursivamente num processo de socialização. As autoras afirmam, nesse sentido, que "certos grupos, como a escola e a mídia, que influenciam a formação de conhecimentos e crenças, também são capazes de controlar, ainda que indiretamente, a formação desses modelos mentais". A partir disso, é possível compreender a identidade como um processo de construção da imagem dos participantes de um determinado contexto social, que se organiza de diferentes formas em suas diferentes manifestações e veículos discursivos. Não nos surpreende, então, que algumas interações exerçam mais influência que outras no que diz respeito à construção da identidade dos indivíduos. Ora, se em algumas situações discursivas certos interlocutores possuem um caráter social de maior aceitação, é compreensível que seus valores e normas identitários sejam mais passíveis à adesão dos participantes.

Observa-se, desse modo, que os estudos discursivos têm-se voltado para sua natureza social, já de alguma data, pois "os participantes constroem significado ao envolverem a si e aos outros no discurso em circunstâncias culturais, históricas e institucionais particulares.", conforme já observou Moita Lopes em 2002. É justamente nessa perspectiva discursiva que buscamos, no presente trabalho, localizar os estudos de construção de identidade. Em sua perspectiva, destaca "[...] alteridade e contexto são categorias básicas para compreender como o significado é elaborado na sociedade." (MOITA LOPES, 2002:30). Observa-se, desse modo, que o autor defende uma perspectiva interacionista de discurso, no qual se localiza a identidade, reafirmando seu caráter processual e de negociação interacional. Ele afirma, nesse sentido, que [...] a construção da identidade social é vista como estando sempre em processo, pois é dependente da realização discursiva em circunstâncias particulares: os significados que os participantes dão a si mesmo e aos outros engajados no discurso. (MOITA LOPES, 2002:32).

A partir da concepção de identidade enquanto processo social, o autor propõe três traços característicos: a fragmentação, ou seja, a heterogeneidade e pluralidade das identidades sociais dos indivíduos; a contradição, relacionada às diferenças identitárias de acordo com os diferentes contextos discursivos (por exemplo, um chefe de uma empresa pode ser reconhecido por seu caráter intransigente, e ao mesmo tempo, ser considerado um carinhoso pai de família), e por fim, a processualidade, isto é, o fato de as identidades não apenas se 
caracterizarem como um processo, mas também de estarem em constante reconstrução. Além disso, o autor chama a atenção para a influência que as relações de poder numa determinada sociedade exercem na construção da identidade social, uma vez que os aspectos contextuais e interacionais permeiam as práticas sociais. Ele afirma: "[...] o poder atravessa a sociedade em diferentes direções dependendo das relações sociais nas quais as pessoas se envolvem por meio de diferentes práticas discursivas" (MOITA LOPES, 2002:36).

Nos estudos sobre identidade, Jungwirth (2007), socióloga alemã, toma uma direção de análise no sentido contrário ao de Moita Lopes. Enquanto este busca observar aspectos sociais pela compreensão da construção de identidade no discurso, a socióloga alemã se preocupa em estudar como as características sociais indicam aspectos identitários no discurso. Ainda que seguindo sentidos opostos, ambos os estudos comungam de uma mesma perspectiva sociodiscursiva da identidade.

Em sua obra baseada na Teoria Queer, a autora apresenta diversas definições que vêm sendo propostas para a Identidade desde a década de 1990, período em que tais estudos passaram a receber maior destaque nas humanidades. As pesquisas mais recentes, no entanto, tendem a conceber identidade como o efeito da normatização. A respeito disso, ela afirma: “A discussão sobre se estudar identidade como efeito da normatização significa então: entender a exigência pela qual se impõe aos indivíduos 'delinearem' a si mesmos, enquanto normas são interiorizadas, como forma de submissão ${ }^{59 "}$ (JUNGWIRTH, 2007:34-35).

A concepção de normatização sugerida por Jungwirth (2007) se aproxima bastante da noção de ideologia defendida por van Dijk (2000), à medida em que compreende ideologia também como um fator de coesão identitária, e se caracteriza como a fundação de representações sociais. Nesse sentido, podemos afirmar que o discurso é também um modo de influenciar e mudar ideologias e fixar identidades, pois é a partir dele que os indivíduos entram em contato com tais sistemas de crenças, orientando valores e manipulando modelos comportamentais e até mesmo interpretações de discursos.

Ainda no que se refere aos efeitos de normatização da identidade, os modelos sociológicos coletivos e individuais, segundo a autora, fundam-se em normas que podem ou não serem aceitas pelo indivíduo. Segundo Jungwirth (2007:185):

O conceito da identidade é cunhado como conceito de estudo (social) em relação com outras categorias pessoais, nas quais este conceito é apoiado em

\footnotetext{
${ }^{59}$ No original: "Die Rede von Identität als Efekt von Normalisierung zu untersuchen, bedeutet demnach: die Anforderung, durch die es den Einzelnen auflegt ist, sich selbst zu 'entwerfen', indem Normen verinnerlicht werden, als Form der Unterwerfung zu begreifen." Tradução nossa.
} 
diferenças binárias, complementares. Geralmente, normas reconhecidas são estabelecidas como normas científicas, nas quais são trazidas para esquemas de desenvolvimento e modelos de dimensão coletiva e individual. Sobre esse plano de fundo emerge o aqui reconstruído discurso sociológico do "indivíduo autônomo" como modo de problematização sobre normas e ordem social, que as normas estabelecem. ${ }^{60}$

Compreende-se, assim, que seu conceito de identidade prevê uma relativa autonomia dos indivíduos em questionar e, consequentemente, selecionar seus próprios modelos e normas identitárias, presentes não apenas no meio social, mas também e, principalmente, no discurso. Decorre daí a ideia de que um não se desassocia do outro. A respeito dessa correlação do discurso e da sociologia nos estudos de identidade, a autora afirma que também é necessário observar outros aspectos que influenciam a construção das identidades dos indivíduos:

É por isso que, na pesquisa histórica serem também incluídas outras questões como contexto sócio-teórico e serem analisadas em relação às disciplinas de sociologia. Os conceitos de identidade e de si mesmo [grifo nosso] valem como "estudos sociais", na medida em que resultam dessas condições institucionais, habitam fenômenos sócio-políticos e podem ser diferenciados da identidade da filosofia. ${ }^{61}$ (JUNGWIRTH, 2007:11)

Sua perspectiva pauta-se, portanto, numa noção sociológica de normas e valores aos quais os indivíduos são submetidos, porém, a autora também compreende, além de questões propriamente sociais, outros aspectos identitários relacionados intrinsecamente aos participantes discursivos. Para ela, a identidade se baseia na tensão entre o eu e o outro, a partir da qual os participantes representam seus papéis sociais. A questão de alteridade também desempenha aqui um papel fundamental, uma vez que é por meio do contato com seu semelhante que o indivíduo adquire a necessidade de se identificar ou de se diferenciar, porém, tal construção parte de uma concepção prévia da imagem do outro, o que culmina

60 Tradução nossa. No original: Der Begriff Identität wird als (sozial-)wissenschaftlicher Begriff in Zusammenhang mit anderen Personenkategorien geprägt, indem er auf binäre, komplementäre Differenzen gestützt wird. Allgemein anerkannte Normen werden als wissenschaftliche Normen etabiliert, indem sie in Entwicklungsschemata und Modelle von kollektiver und individueller Dimension gebracht wurden. Vor diesem Hintergrund erscheint der hier rekonstruierte sozialwiessenschaftliche Diskurs vom 'autonomen Subjekt' als Problematisierungsweise über Normen und die Ordnung, die sie begründen."

61 Tradução nossa. No original: "Darüber hinaus werden in die vorliegende wissenschaftshistorische Untersuchung auch andere als sozialtheoretische Texte einbezogen und in Zusammenhang mit der Institutionalisierung sozialwissenschaftlicher Disziplinen analysiert. Die Begriffe Identität und Selbst gelten als 'sozialwissenschaftlich', insonfern sie unter diesen intitucionellen Bedingungen entstehen und sich auf gesellschaftspolitische Phänomene beziehen und so von der Tradition der Identitätsphilosophie unterschieden werden können," 
novamente no conceito de processualidade da identidade, dado que a cada interação, os sujeitos sentem a necessidade de criar uma outra imagem de si e de seus interlocutores.

Bauman (2005:17-18) define essa mesma questão como fluidez, isto é, o caráter inacabado da identidade dos indivíduos. Por isso, as pessoas que buscam por suas próprias identidades nunca a encontrarão, pois se trata de uma concepção em constante processo de formação e transformação. Em suas palavras:

[...] o 'pertencimento' e a 'identidade' não têm a solidez de uma rocha, não são garantidos para toda a vida, são bastante negociáveis e revogáveis, [...] as decisões que o próprio indivíduo toma, os caminhos que percorre, a maneira como age - e a determinação de se manter firme a tudo isso - são fatores cruciais tanto para o 'pertencimento' quanto para a identidade. [...] Só começarão a ter essa ideia na forma de uma tarefa a ser realizada, e realizada vezes e vezes sem conta, e não de uma só tacada.

É nesse sentido que o autor também defende que as identidades se constroem dentro do que ele chama de "comunidades fundidas por ideias" (BAUMAN, 2005: 17), ou seja, espaços sociais que se organizam sobretudo pela comunhão de ideologias. E por estarmos também inseridos nessas comunidades, nossas identidades são, em grande parte, construídas pelos outros ao longo das negociações das interações. "As identidades flutuam no ar, algumas de nossa própria escolha, mas outras infladas e lançadas pelas pessoas em nossa volta [...]" (BAUMAN, 2005: 19).

Para Keupp (1999), esse processo de construção entre interlocutores gera uma tensão que segundo ele é comparável a um trabalho de patchwork (algo semelhante a uma colcha de retalhos). De acordo com essa metáfora, a identidade é construída coletiva e individualmente, com base nas normas e valores impostos socialmente, ao mesmo tempo em que contém traços dessa recíproca tensão entre o eu e o outro. É preciso destacar que, além disso: essa colcha de retalhos pode possuir o efeito de normatização a partir dos valores e normas selecionados para sua composição. É interessante ressaltar aqui que a proposta de Keupp também pode ser compreendida como uma proposta metodológica de análise das identidades.

Assim, se as identidades são fluídas, como afirma Bauman (2005) e fragmentadas, segundo Moita Lopes (2002), é possível reconstruir as pistas da imagem da criança - e porque não do lugar da infância - dentro de um recorte espaço-temporal, como nos propomos a realizar na presente pesquisa. Os fragmentos que temos disponíveis a partir das análises dos capítulos anteriores foram, de fato, veiculados por adultos e presumivelmente escritos por crianças em situações políticas e comunicacionais bastante específicas. As seções que seguem 
nesta Dissertação se realizam no esforço de costurar uma colcha a partir desses retalhos pequenos, porém significativos, recolhidos ao longo de todo este trabalho.

\subsubsection{A construção da identidade da criança em "Hilf mit!"}

Antes de iniciarmos a discussão dos resultados obtidos no que se refere às questões de identidade, compreendemos a importância de ressaltarmos novamente a delicada questão da autoria infantil atribuída aos textos analisados. No entanto, entendemos que tal questão não inviabiliza esta pesquisa, uma vez que nos propusemos a reconstruir os rastros deixados por essas marcas identitárias a partir dos documentos disponíveis. Além disso, sabendo-se da intrínseca relação entre alteridade e identidade - como ressaltado por Grigoletto (2006) e Oliveira (2007), não devemos nos esquecer de que toda imagem que construímos de nós mesmos se fundamenta também nas expectativas dos nossos interlocutores.

Desse modo, parece-nos imprescindível destacar que as condições de produção, edição e divulgação dos periódicos infantis, apesar de não nos permitirem afirmar de modo assertivo a respeito da real autoria dos textos assinados por crianças, não se configuram como uma dificuldade desta pesquisa, mas sim como uma característica própria dos nossos corpora, uma vez que não buscamos aqui compreender como as crianças pretendiam construir essa imagem da infância, mas sim como os meios de comunicação queriam - ou ao menos possibilitavam que esses elementos de identificação fossem criados. O que está em jogo não é propriamente o que a criança diz sobre si mesma, mas sim o que essa complexa interação entre os editores, os possíveis enunciadores e seus enunciatários em determinados contextos sociopolíticos indicam sobre o lugar da infância na década de 1930 no Brasil e na Alemanha, em veículos de comunicação em massa.

Isto posto, iniciamos nossa discussão a partir das questões vinculadas justamente à presença de um corpo editorial responsável pelo controle minucioso das publicações do jornal escolar "Hilf mit!". Os resultados obtidos das análises do primeiro capítulo apontam para a forte influência da Associação nacional-socialista de professores, que inclusive assinavam as capas das primeiras edições, conforme observamos nas imagens a seguir, em que abaixo do título lê-se "Herausgeber: N.S. Lehrerverband ${ }^{62 ":}$

\footnotetext{
${ }^{62}$ Em português: "Editor: Associação dos professores do Nacional Socialista".
} 

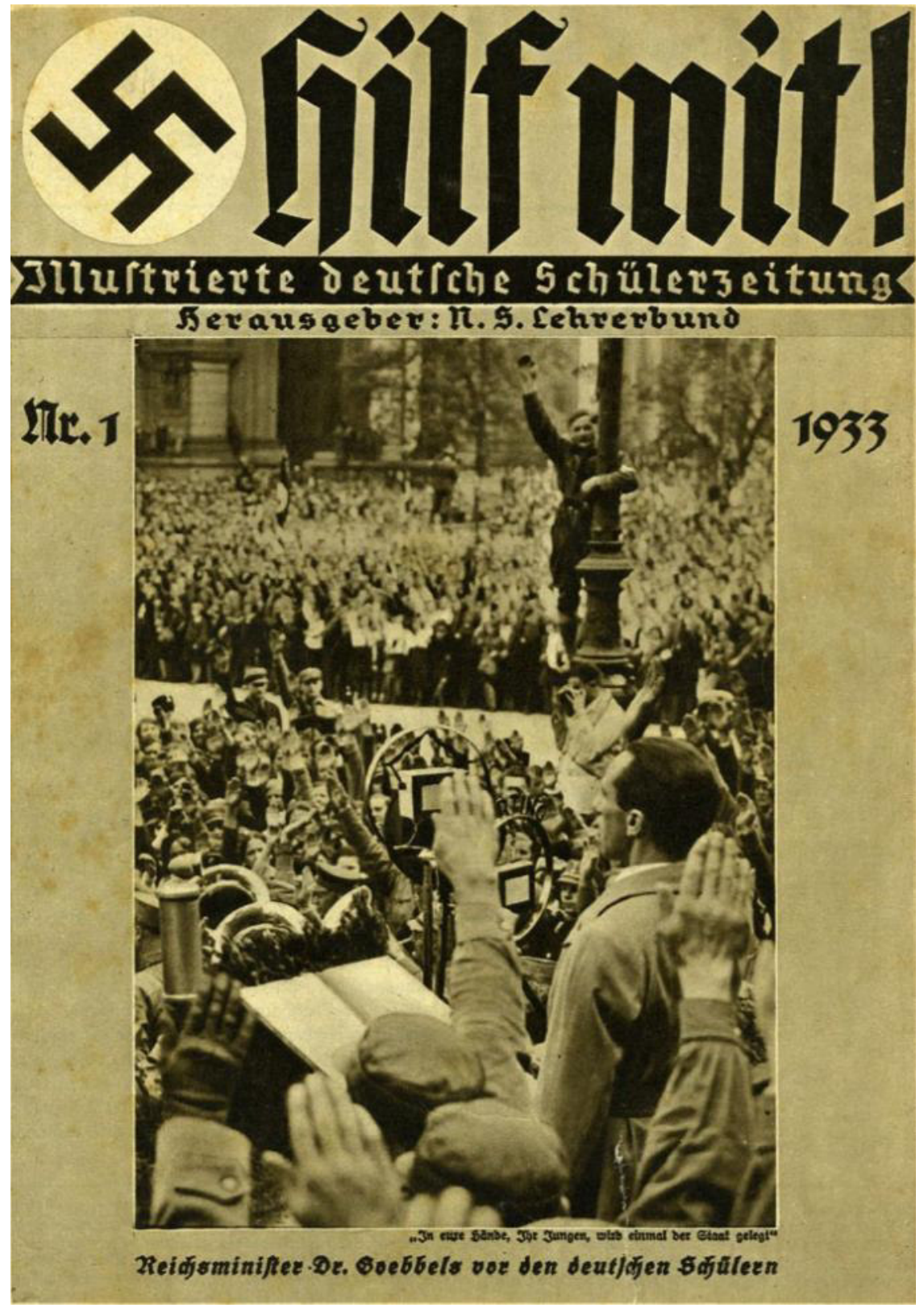

Figura 25: Capa da primeira edição do jornal escolar "Hilf mit!", 1933

A existência de tal grupo editorial comprova a estreita relação entre o jornal e o governo de Adolf Hitler, o que também pode ser observado a partir da veiculação de textos voltados à doutrinação política e ideológica, como já apontado também no primeiro capítulo. Somado a isso, encontramos também a divulgação de fotos de cunho militar, sempre apresentando crianças e adultos com fardas oficiais - desde grupos escolares ou juvenis até mesmo do exército e da $\mathrm{SS}^{63}$ - ou em situações de disciplina e obediência, como a organização em filas, por exemplo, conforme registrado na seguinte imagem:

\footnotetext{
${ }^{63}$ Schutzstaffel, ou Tropa de Proteção.
} 


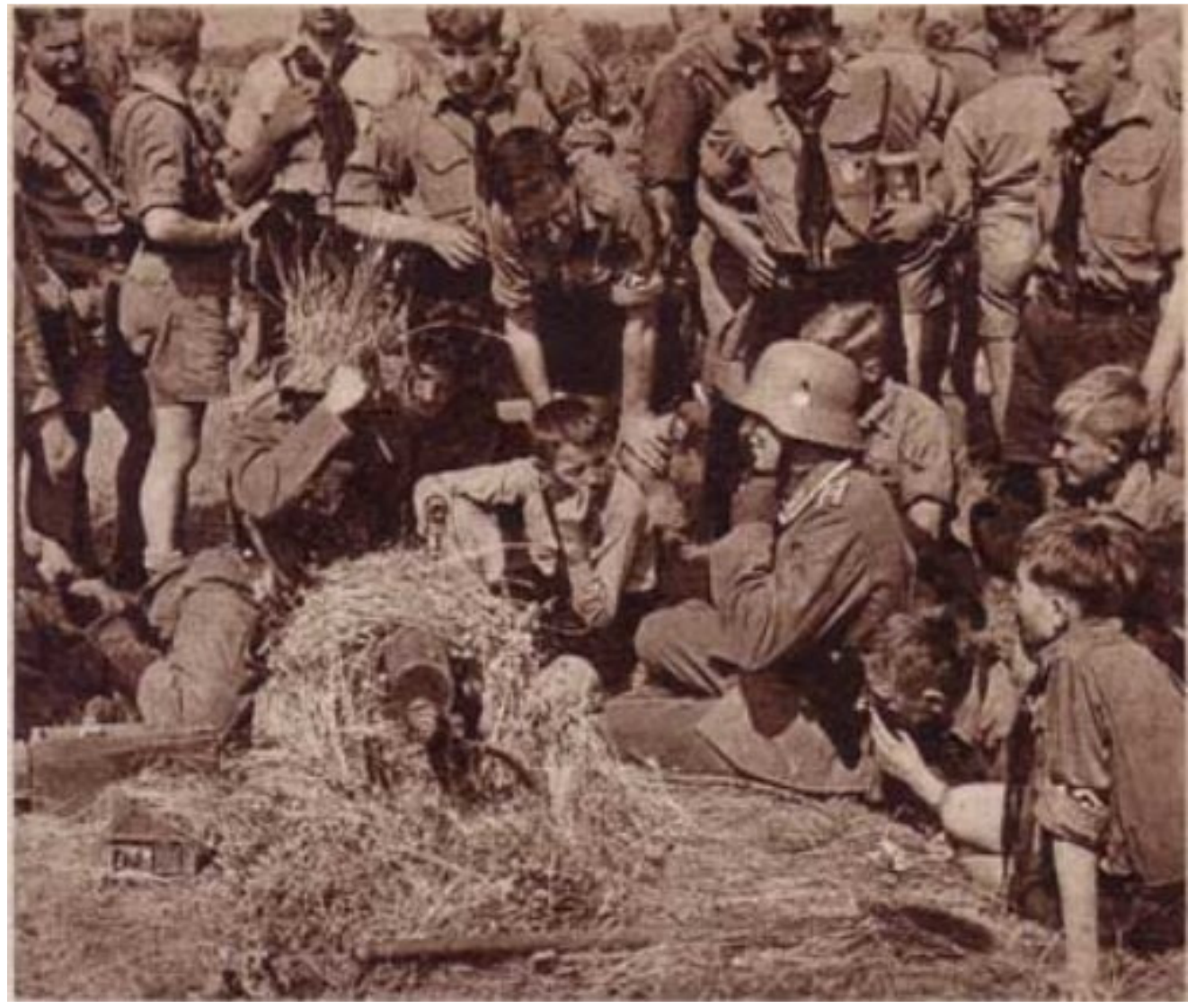

Figura 26: Imagem da viagem das jovens tropas alemãs pelo território nacional. Hilf mit!, dezembro de 1935.

A constante referência a elementos militares no jornal, bem como a relatos de doutrinação ideológica, servem de indício para uma importante questão em termos da interação que os editores buscaram estabelecer com seus leitores: todas as pessoas apresentadas no periódico, independentemente da idade ou do gênero, são apresentadas como modelos de comportamento a serem seguidos pelo público alvo - crianças em idade escolar. Com isso, podemos afirmar que, acima de tudo, a identidade infantil construída em Hilf mit! é a de um modelo alemão de conduta - um Vorbild ${ }^{64}$

Outro dado bastante importante a ser observado - conforme abordado no início do presente capítulo - é a caracterização dos textos como discurso autoritário, ou seja, como uma reprodução de ideologias diretamente relacionadas a uma figura de poder, no caso o chefe de Estado Adolf Hitler. Esse traço confere a esse Vorbild da criança alemã uma de suas principais marcas: o respeito às hierarquias e, sobretudo, à autoridade do Führer. Além disso, se tomarmos a concepção de van Dijk (2000), podemos compreender esse discurso de

\footnotetext{
${ }^{64}$ Palavra da língua alemã definida pelo dicionário Duden como "Pessoa ou objeto, que é vista como padrão idealista, como exemplo, à qual se segue."
} 
autoridade como um fator de coesão identitária da nação alemã em torno da figura do próprio Führer, uma vez que ele não simbolizava apenas um papel político, mas sobretudo a personificação da ideologia nazista e da "raça alemã".

A partir desse padrão de coesão identitária, podemos observar uma construção mais homogênea e massificada da representação da criança alemã por parte desse domínio político, escolar, midiático e familiar. A exemplo disso, citamos alguns dos resultados alcançados nas análises do capítulo dois, no que se refere à seleção lexical utilizada para se referir a esse grupo como, crianças, povo, companheirismo, camaradas, alemães, unidos, irmãos, espertos, em serviço, satisfeitos, animados. Ressaltamos, ainda, que tais termos não apenas apresentam uma imagem unida e massificada da infância da época, como o faz de modo bastante positivo e entusiasta, o que também é utilizado como um reforço a essa figura do Vorbild veiculada pelo periódico.

Como principais elementos de identificação grupal dessa representação infantil em termos qualitativos, destacamos também as recorrentes referências a símbolos nacionais, como a menção à bandeira e ao uso do uniforme - tanto nos textos escritos por crianças, como nas fotografias publicadas. Ambos os elementos contribuem ainda mais para a construção de uma figura de representação mais fechada e generalizada da criança no período do nazismo. Destacamos, também, a referência ao sangue da "raça alemã" no seguinte trecho do poema recolhido de "Menina no Acampamento":

\author{
A bandeira chama \\ E atrai tão bem. \\ Mãe, eu queria estar lá! \\ Mãe, eu não posso ficar de fora, \\ Ouça o grito do meu sangue! $(\mathrm{H} 2)^{65}$
}

Nesse poema, a enunciadora implora a sua mãe que lhe permita participar da Liga Federativa de Meninas, afirmando ser essa uma necessidade física. Seu corpo é uma parte da ideologia, pois para ela ser alemão é algo genético e não uma mera questão de identificação nacional. Tal ideia, se relacionada à noção de eugenia da raça alemã - ou seja, à necessidade de se higienizar um grupo étnico a partir da extinção de outras "raças" bem como quaisquer

\footnotetext{
${ }^{65}$ Tradução nossa. No original:

"Die Fahne ruft

Und lockt so gut.

Mutter, wär' ich dabei!

Mutter, ich darf nicht abseits stehen, Hör meines Blutes Schrei!
} 
outros indivíduos que não se enquadrassem no padrão físico ou ideológico alemão apresenta-se como uma importante característica da construção desse Vorbild: a identificação não ocorre apenas pelo comportamento e respeito a uma autoridade e a uma bandeira, ela é sobretudo racial, étnica e biológica. Apenas uma criança nascida de pais alemães e cristãos poderia representar essa imagem. E mais do que isso, a construção desse Vorbild serve, acima de tudo, para padronizar ideologicamente tais crianças.

Essa representação não era apenas racista, mas também bastante sexista. Em "Menina no Acampamento", podemos observar a menção ao serviço doméstico como algo que as meninas gostam de realizar, e o fazem muito melhor que os meninos, como destacamos a seguir, na comparação estabelecida entre os membros da JH e da Liga Federativa de Meninas:

Os meninos na JH, como nós sempre lemos e seus relatos de viagem, têm um medo muito grande dos serviços de cozinha e encaram-nos como um castigo. Conosco isso era totalmente diferente, e Ruth tinha que usar seus esforços para separar o trabalho de cozinha. $(\mathrm{H} 2)^{66}$

Essa representação da figura infantil feminina servia de manutenção das relações de poder entre homens e mulheres na sociedade, de modo a se firmar mais um tipo de hierarquia: a familiar. Desse modo, a construção da identidade da criança no regime totalitário alemão, apesar de se pretender igualitário - pois é massificador -, é na verdade bastante hierárquico e desigual, e entre as próprias crianças se observam disparidades quanto ao gênero.

No que diz respeito à relativa autonomia identitária dos sujeitos, prevista por Jungwirth (2007), observamos pouco espaço para a criança se representar de um modo mais independente nesse jornal, pois seus textos eram cerceados e, provavelmente, editados e selecionados, por todo um aparato ideológico e político do corpo editorial do periódico. $\mathrm{O}$ discurso autoritário nazista é reproduzido de tal modo na voz dessas possíveis crianças que sua autonomia de construção de identidade não aparecia de maneira muito evidente. Apenas uma característica da Vorbild de autoria infantil não é mencionada nos textos assinados por adultos, que é justamente a exaltação da importância exercida pelos grupos juvenis nos programas do governo. Para o Vorbild, participar não é apenas algo desejável, mas também é significativo para o resto da população.

\footnotetext{
${ }^{66}$ Tradução nossa. No original: "Die Jungen in der JH haben, wie wir immer wieder in ihren Fahrteberichten lesen, eine ziemlich große Bange vor den Küchendienst und sehen ihn als Strafdienst an. Bei uns war das ganz anders. Jede wollte kochen, und Ruth hatte ihre Mühe, die Küchendienst zu verteilen."
} 


\subsubsection{A construção da identidade da criança em O Tico-Tico}

Assim como em "Hilf mit!", a autoria infantil dos textos de O Tico-Tico Mundano não pode ser confirmada. Além disso, não devemos nos esquecer da provável influência dos editores das revistas em selecionar quais enunciados seriam publicados e até mesmo editá-los. No entanto, parece-nos possível afirmar que, na revista brasileira, o governo de Vargas não exerceu o mesmo grau de influência como ocorrera no jornal alemão. É fato que o corpo editorial de "O Tico-Tico" fosse composto por pensadores políticos, como Manoel Bonfim, bastante engajados no desenvolvimento socioeconômico do país e nos ideais positivistas relacionados à infância, porém, a revista em questão não tinha leitura obrigatória nas escolas e sequer era controlada por algum órgão do Estado. Desse modo, podemos afirmar que havia, sim, uma influência política na produção do periódico, mas de um modo mais brando se comparada à "Hilf mit!".

De acordo com o pensamento político e ideológico dos editores, "O Tico-Tico" era uma revista voltada ao investimento simbólico na formação cultural da criança brasileira. Tal formação não ocorria, entretanto, obrigatoriamente no espaço escolar, mas sim em situações de recreação e lazer. Dado esse fato, compreendemos que as interações que se estabelecem nos dois periódicos apresentam algumas diferenças, sem se caracterizarem, porém, como antagônicas, pois ambas visavam à formação das crianças, sendo uma de modo mais doutrinário e de caráter institucional, e outra mais lúdica e informal.

A importância de se compreender o tipo de interação em que se fundava a revista brasileira nos revela características bastante importantes em termos de construção de identidade infantil no Brasil de Vargas, uma vez que, por não ter um objetivo de doutrinar as crianças, mas sim de fomentar um repertório cultural mais amplo, "O Tico-Tico" não apresenta a criança como um Vorbild, mas sim como o futuro da nação. A metáfora da criança como "os condutores do Brasil de amanhã" (T6) apresenta uma imagem inacabada da infância no país. As crianças da revista são um "vir a ser"; há, de fato, uma normatização de comportamentos e de características físicas para a criança ideal brasileira - como discutiremos a seguir -, mas ela serve mais como uma base norteadora do que propriamente como um modelo padronizado e massificado a ser seguido.

Parece-nos possível afirmar que aos editores não importava tanto a criação de um Vorbild da criança naquele momento, mas sim de moldar seu caráter para o futuro, para o cidadão que ela seria um dia. A infância registrada em "O Tico-Tico" era, antes de tudo, um processo de formação, uma lista de condutas morais. Não se vê aqui um modelo tão concreto 
e acabado como o encontramos em "Hilf mit!", jornal que, ao contrário, personifica a ideologia numa única figura de autoridade, e dela deriva a representação da criança. Possivelmente, caracterização dos enunciados da revista brasileira como discurso interiormente persuasivo, conforme discutido na seção 3.1.2, deva-se também a esse tom inacabado da construção da identidade infantil da época, visto que a inexistência de uma figura de autoridade estatal como corporificarão de uma ideologia é sintomática também de uma representação menos concreta e massificadora de toda uma nação.

Porém, ainda que de modo mais abstrato, é possível encontrar em "O Tico-Tico" efeitos de normatização na representação da criança da época, sobretudo no que diz respeito a comportamentos, como podemos observar a seguir na figura 27, na história de Esopo, publicada com ilustrações, cuja moral diz: "Quem maltrata um animal não mostra bom natural". A noção de "bom natural" apresentada na fábula não se refere apenas a um padrão de comportamento considerado adequado e esperado das crianças, mas sobretudo a natureza biológica de tal normatização. Assim, agir segundo o que se preconizava não era uma mera questão moral, mas sim racial. Não é por acaso que os personagens negros exerciam papel secundário nas histórias em quadrinho, visto que, na verdade, eles não eram o público alvo da revista. A Sociedade Anonyma $\mathrm{O}$ Malho via apenas a criança branca - mais especificamente o menino branco - como o futuro da nação e é a ele que os padrões são ensinados. Porém, ao contrário do que ocorria na Alemanha nazista, as outras raças não deveriam ser dizimadas para se promover a "pureza" étnica da nação; na sociedade brasileira, a segregação servia antes para subjugar e explorar as minorias, por isso o mau comportamento é tido como algo natural para os personagens negros das histórias da revista, como se observa na figura 28. 


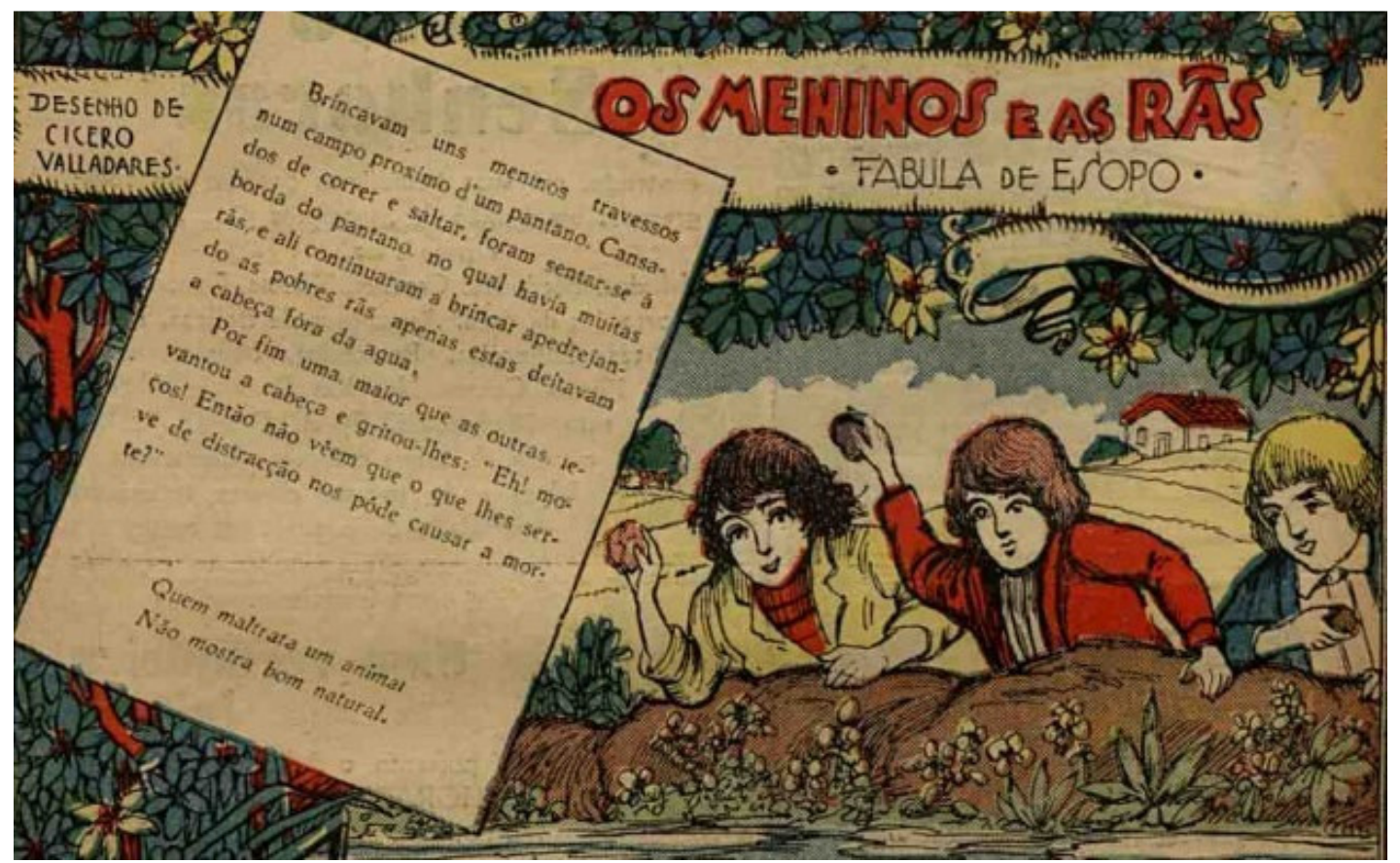

Figura 27: Capa com história ilustrada de Esopo, "O Tico-Tico" edição 1479, fevereiro de 1934

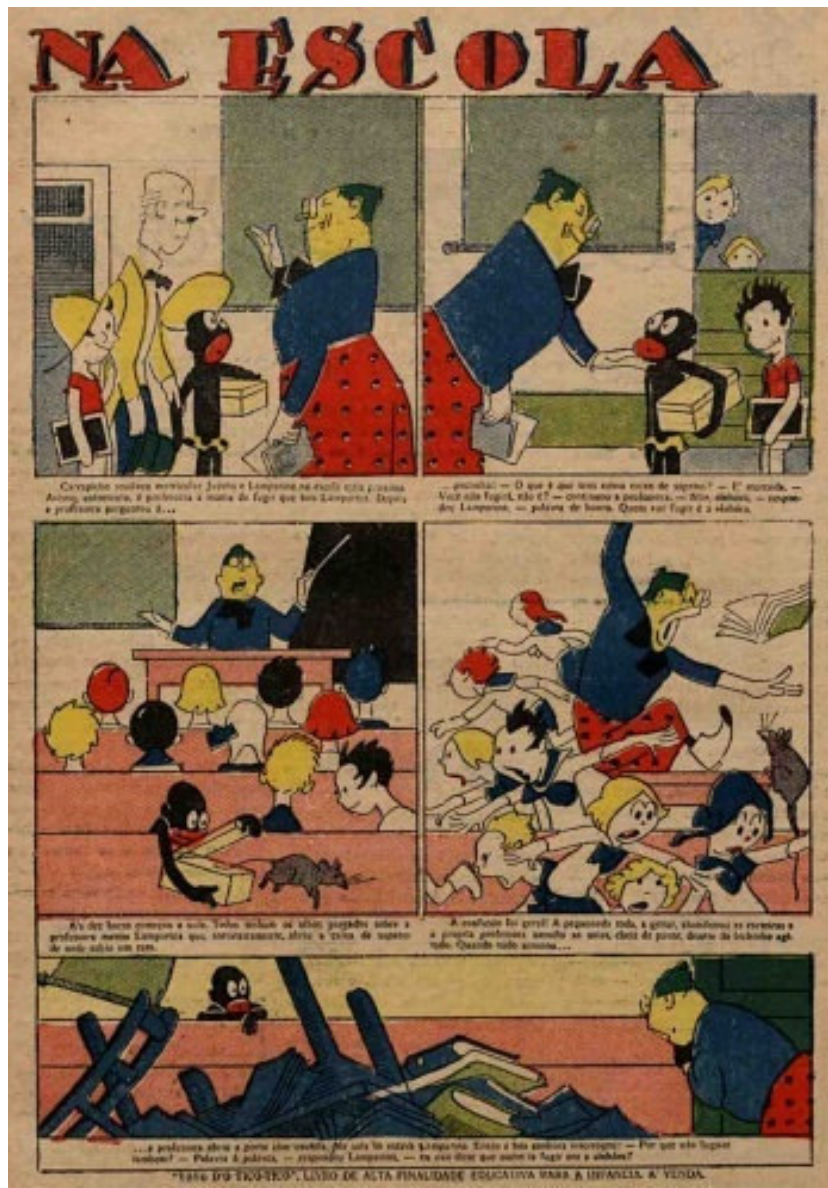

Figura 28:História ilustrada Na Escola, "O Tico-Tico" ed. 1407, abril de 1934. 
Nos quadrinhos da figura 28, observamos o personagem Lamparina, menino negro e de menor poder aquisitivo - como demonstra sua vestimenta -, em seu primeiro dia de aula. Assim que entra na sala, dirige-se à última fileira sem que isso lhe fosse solicitado, como se ele soubesse que o espaço a ele destinado era justamente aquele. No decorrer da aula, Lamparina abre sua caixa, de onde sai um rato, assustando os demais colegas e, principalmente a professora. A traquinagem não é, no entanto, condenada pelos autores da história, possivelmente porque a natureza de Lamparina era, de fato, incivilizada. Por conta disso, apenas as peraltices das personagens de crianças brancas eram corrigidas pelos editores, uma vez que estas pertenciam à raça civilizada, cujo comportamento deveria ser corrigido.

Em relação aos textos de autoria atribuída às crianças, observamos o mesmo tom jocoso que se mantém em toda a revista, o que indica uma concepção mais lúdica da infância por parte de todos os enunciadores e dos editores. E nesse tom jovial, o discurso infantil de "O Tico-Tico" consegue se desligar das referências de autoridade da época, estabelecendo-se como uma brincadeira entre crianças, em que estas acabam por conquistar maior autonomia identitária em relação aos pequenos enunciadores de "Hilf mit!". Isto é, a partir do momento em que o discurso dessas crianças não se configuram com um discurso autoritário, por não se referir a uma ideologia diretamente ligada à figura de poder, estes jovens conseguem criar novos conceitos de normatização entre si.

A exemplo disso, podemos citar a referência a meninas, exaltando sua inteligência e valentia, conforme apresentado na figura 25 do capítulo anterior, bem como a delicadeza dos meninos - conceitos que eram atribuídos sempre ao gênero oposto nos discursos dos adultos. Porém, observamos que nem todas as novas construções identitárias das crianças rompem com os padrões estabelecidos por adultos, como é o caso de atribuição de profissões específicas para cada gênero, como aviador e mecânico para meninos, e florista para meninas. Isso aponta para o fato de que tal autonomia identitária se constitui de modo bastante relativo, uma vez que os indivíduos, a selecionavam dentro das possibilidades de normas disponíveis em seus círculos sociais.

\subsubsection{Correlação entre os processos de construção de identidade nos periódicos brasileiro e} alemão

Em termos de identidade, ambos os periódicos apontam para uma seleção de cunho racista do ideal de criança da época nos dois países. Porém, as ideologias circundantes implicam em construções identitárias um tanto diferentes - mas não de todo antagônicas entre 
si. A exemplo disso, podemos citar a noção biológica e racial muito aplicada nos dois corpora para explicar os comportamentos dos pequenos leitores, seja como o "bom natural" de toda criança branca brasileira, ou o "puro sangue" alemão que clamava pela união e partilha com seus pares. No entanto, tais construções sociais - fortemente vinculadas à noção de higienização racial - serviam a objetivos políticos diferentes. Para a revista brasileira, esperava-se tanto formar o caráter do futuro da nação - mais especificamente dos meninos brancos e de classes mais abastadas - como também ensinar às crianças o papel social de cada um: as mulheres nos afazeres domésticos e os negros em situação de subserviência e sem aptidão para os estudos e atividades um pouco mais intelectualizadas. Já em "Hilf mit!", a higienização racial aponta para a total exclusão de figuras não correspondentes ao ideal da "raça ariana", uma vez que nenhuma outra etnia é sequer mencionada nos textos; aliás, o propósito do regime nazista era, como sabemos, exterminar outras etnias presentes na Alemanha àquela época.

Com isso, compreendemos que os interesses políticos exerciam, de fato, bastante influência na construção da identidade infantil apresentada pelos periódicos. No caso de "O Tico-Tico", não apenas as delimitações dos papéis sociais, como também o ideal positivista que apontava os meninos como o futuro da nação, indicam um engajamento político bastante significativo no desenvolvimento socioeconômico do Brasil das décadas subsequentes. Por outro lado, no jornal alemão, toda a produção midiática e textual foi criada como uma propaganda de um regime totalitário que tinha o Führer como figura de personificação de toda sua ideologia, o que garantia coesão de toda a "raça alemã" nessa mesma imagem, porém com suas próprias hierarquizações, o que segregava toda a população em diferentes castas de acordo com o gênero, idade e importância politicomilitar, porém todas espelhadas na figura de autoridade máxima atribuída a Adolf Hitler.

Tal coesão identitária centrada na figura do Führer aponta para uma construção bastante homogênea e massificada da identidade alemã como um todo, o que não podia deixar de ser similar no tratamento das crianças, como ocorre a partir da representação do "Vorbild" da criança da Alemanha nazista. Importa ressaltar ainda que tal construção visava, sobretudo, à doutrinação dos leitores a partir da representação de uma figura infantil bem sucedida de acordo com os preceitos do governo, de modo a normatizar os comportamentos até a concepção de imagem de si das demais crianças do país.

No que se refere ao processo de construção identitária na revista "O Tico-Tico", observamos que o objetivo principal da revista era a normatização de comportamentos no sentido de corrigir e moldar o caráter de um modo bastante lúdico e informal. E justamente 
pelo fato de a criança ser representada pelos adultos como o futuro da nação - ou seja como uma figura que ainda se tornaria algo importante para a sociedade brasileira - , sua identidade se apresenta de modo bastante inacabado, motivo pelo qual não se verificou a mesma massificação que no corpus alemão, uma vez que neste contexto sociopolítico não havia uma coesão identitária tão unificada, e tampouco era concentrada na figura da autoridade máxima estatal, no caso Getúlio Vargas.

Muito provavelmente, por conta dessa imagem inacabada da criança representada na revista brasileira, os textos de autoria presumivelmente infantil apresentaram uma certa autonomia de construção identitária um pouco mais demarcada que nos textos de "Hilf mit!", uma vez que se verificou o rompimento com alguns padrões e normas de cunho sexistas fortemente defendidos nos textos assinados por adultos, como é o caso do elogio à inteligência e valentia de algumas meninas e à amabilidade de alguns meninos, conforme já apresentado no tópico anterior deste mesmo capítulo. No entanto, alguns valores foram mantidos, o que nos chama à necessidade de relativizar os limites alcançados por tal autonomia por parte das crianças. No jornal alemão, foi possível também localizar um padrão de autonomia identitária nos textos atribuídos às crianças, a qual, por sua vez, apontava para a importância das crianças no regime nazista - a única característica não mencionada nos textos dos adultos nas edições analisadas. 


\section{CONCLUSÃO}

Esta pesquisa teve por objetivo estudar o discurso da mídia voltado ao público infantil, para conhecer o processo de construção de identidades das crianças em relação aos contextos sociopolíticos específicos no Brasil e na Alemanha na década de 1930. Devido a isso, entendemos necessário investigar inicialmente o momento político vivido nos dois países para, em seguida, buscar compreender como estas questões puderam influenciar os discursos, tendo por embasamento fundamental os preceitos de Voloshínov/Bakhtin (1992[1929]) e van Dijk (2012) no que se refere à importância de se promover um estudo interdisciplinar e contextualizado dos discursos.

Num primeiro momento, pudemos observar que, embora ambos os países vivessem um momento político bastante marcado por movimentos nacionalistas, eles apresentavam características particulares um tanto distintas entre si, ainda que não fossem de todo opostas. O próprio grau de nacionalismo entre os dois países já apresenta uma variação considerável, visto que no Brasil, apesar de tal característica estar de fato presente em vários segmentos da sociedade, não era, como na Alemanha, a força motriz e impulsionadora da população. Parece-nos bastante provável afirmar que isso se deve em grande parte ao modo de construção de identidade nacional, uma vez que - como indicamos a seguir - o povo alemão buscava se identificar de modo mais coeso, tendo como modelo a figura do Führer.

A menção ao governante alemão também nos traz indícios relevantes no que se refere aos diferentes tipos de governo ao qual os dois países estavam àquela época submetidos e, ao que tudo indica, parecem ter exercido forte influência tanto nos textos quanto nos veículos de comunicação aqui estudados. Enquanto a Alemanha vivia uma ditadura totalitarista, a nação brasileira experienciava o início de um regime de caráter mais democrático, como se propunha o primeiro governo de Vargas, com sua nova Constituição.

Ressaltamos ainda outra característica em comum entre os dois países: a noção de eugenia e a pretensão de higienização racial da população. Isto é, ambas as nações se pautavam por uma visão de cunho biológico para a formação de vínculo com seus compatriotas, sobretudo na Alemanha nazista, na qual se acreditava ser a "raça alemã" geneticamente superior às demais e, por isso, seria necessário 'limpar" o país das raças consideradas impuras. No Brasil, assim como a força do nacionalismo, esse pensamento higienista era mais brando, pois não visava à exterminação de nenhuma etnia, apenas buscava segregar os papéis sociais atribuídos a cada grupo. 
Por conta dessa mesma visão higienista um pouco mais branda veiculada na sociedade brasileira àquela época, podemos mencionar uma última característica sociopolítica bastante presente nos discursos desse período, sobretudo no que se refere aos textos encontrados em nosso corpora: a proposta da pedagogia ortopédica, conforme definida por Carvalho (2001) isto é, a intenção política de educar a criança para corrigir desvios de comportamento considerados inadequados. O educando era, nessa concepção positivista, um ser em formação e não um indivíduo já autoconsciente. A ideia era moldar toda uma geração para que o país, que também estava engatinhando num novo momento de progresso econômico e político, atingisse seu destino próspero. Na Alemanha, porém, a educação tinha um objetivo mais imediato de difusão ideológica nazista e, por conta disso, o jornal "Hilf mit!" poderia ser considerado também uma propaganda política às crianças diretamente vinculada ao espaço escolar.

As análises, efetuadas a partir dos preceitos da Comunicação, em especial segundo Lopes (2005) e Wolf (1999), permitiram observar o que segue quanto ao repertório cultural e aos espaços de circulação nos dois periódicos selecionados. Destacamos a relação que se apresentava junto ao ensino institucionalizado. No caso de "Hilf mit!", a obrigatoriedade da leitura não apenas indica seu caráter de ensino oficial, como também aponta para a escola como principal espaço de circulação desses discursos, além de ter um repertório de gêneros discursivos mais restrito e muito voltado para a exaltação do sentimento nacionalista alemão e para a difusão da ideologia nazista.

Já em "O Tico-Tico", observamos um repertório cultural muito mais diversificado, se comparado ao jornal alemão, contando com vários gêneros discursivos e textos bastante lúdicos, apesar de se verificar também um discurso bastante racista na revista. O corpo editorial da revista também traz indícios bastante importantes em termos de produção midiática, uma vez que a revista brasileira era produzida por um grupo de intelectuais ligados ao governo e entusiasta dos pensamentos nacionalista e progressista que circulavam no país e, devido a isso, selecionavam para publicação textos de caráter não apenas lúdicos, mas também que suscitassem o bom comportamento das crianças. "Hilf mit!", por sua vez, era publicada pela Associação nacional-socialista de professores" e, por conta disso, também se fazia valer de textos atribuídos às crianças para usar como modelo de obediência ao regime do Partido Nacional Socialista.

Em termos de estudos argumentativos, o preceito de Plantin (2008) a respeito dos objetivos finais aos quais todo discurso se orienta, permitiu-nos observar tais características de orientação dos textos de autoria atribuída às crianças. No caso dos objetivos 
argumentativos de O Tico-Tico Mundano, constatamos a necessidade dos enunciadores de enaltecer as qualidades de seus colegas de acordo com os valores da época, de modo bastante lúdico - sobretudo com o recurso das paródias. Com isso, buscava-se em tais discursos a difusão de padrões físicos e comportamentos considerados desejáveis por tais enunciadores, o que em algumas situações quebrava as expectativas das características aceitas como adequadas nos textos assinados por adultos - como é o caso da constante menção a meninas por sua sensualidade e a meninos por sua delicadeza e gentileza.

Nos textos assinados por crianças em "Hilf mit!", os objetivos argumentativos se voltavam sumariamente a firmar a importância dos grupos juvenis, isto é, a Juventude Hitlerista e a Liga Federativa de Meninas, para o regime nazista, além de convidar seus leitores - pertencentes à mesma raça - a partilharem dos mesmos ideais, afirmando a supremacia da cultura alemã sobre as demais. Nesse periódico, o discurso adulto era citado como um recurso argumentativo para a validação de suas ações, no intuito de as crianças se colocarem em igualdade com os mais velhos em termos de prestígio político e militar.

E em se tratando de validação, entendemos necessário retomar os conceitos propostos por Klein (1980) em relação às validades coletivas e as validades aceitáveis, isto é, o uso de conjuntos de valores já aceitos num dado grupo para a validação de ideais que ainda não eram compartilhadas entre tais participantes. No caso de "Hilf mit!", esse tipo de estratégia pode ser verificado justamente nesse intuito de se fazer valer de um discurso já aceito a respeito da importância de se lutar lado a lado com seus compatriotas, para se colocarem como figuras de papel fundamental nas conquistas políticas e sociais do governo de Hitler. Em O Tico-Tico Mundano, os textos de autoria presumidamente infantil utilizam um discurso de caráter padronizador no que se refere a características físicas e morais tidas como aceitáveis, listandoas e categorizando-as juntamente de outras qualidades que sequer eram mencionadas em textos assinados por adultos ao longo de todas as edições observadas.

No que diz respeito à proposta de Bakhtin (2015 [1930]) para o estudo da palavra de outrem nos discursos, observamos nos textos de O Tico-Tico Mundano a presença de um discurso interiormente persuasivo, uma vez que se apresentava desvinculado de quaisquer figuras de poder e, por conta disso, pudemos verificar nesse corpus uma maior liberdade em termos de aceitação ou recusa das ideologias veiculadas pelos adultos no mesmo domínio midiático. Já em "Hilf mit!", os textos atribuídos às crianças traziam como predominante a característica do discurso autoritário, pois além de demonstrar total aceitação à ideologia circundante - não apenas na revista, mas em toda a sociedade alemã da época -, a imagem do Führer é posta claramente como a figura de autoridade máxima nesses discursos. 
Estas características discursivo-ideológicas também apontam para os tipos de negociações e interações que ocorriam nesses textos e que, de acordo com autores como Grigoletto (2006) e Moita Lopes (2002), estão bastante ligadas às construções identitárias nesses mesmos discursos. Tal questão aparece de modo bastante marcado em nosso corpus alemão, em que as crianças - supostas enunciadoras - colocam-se neste jornal como exemplos para seus enunciatários, uma vez que são publicados apenas textos de crianças que assumiam para si esse discurso autoritário vinculado à figura de Adolf Hitler, de modo a se firmarem como um "Vorbild" para seus compatriotas. Em O Tico-Tico Mundano, a negociação com alguns valores e ideologias já aceitos apontam para o que Jungwirth (2006) define como uma relativa autonomia identitária, uma vez que esses enunciadores - se forem de fato crianças rompem com alguns desses padrões de normatização impostos a eles, colocando-se, em algumas situações, de um modo diverso ao que eram representados por adultos.

Não podemos, no entanto, deixar de mencionar a influência de outros fatores para a construção dessa identidade infantil. Ainda que as crianças sejam realmente as autoras desses textos, devemos ressaltar a presença de editores que, em seus papéis de Gatekeepers, selecionaram quais textos circulariam de acordo com seus interesses políticos, econômicos e midiáticos. Por isso, a identidade da criança que se apresenta neste trabalho é permeada por diversas outras construções que não necessariamente dizem respeito às construções que esses enunciatários fazem de si mesmos.

No intuito de reconstruir esse Patch-work, conforme proposto por Keupp (1999), entendemos ser necessário concluir este trabalho recuperando também os demais participantes envolvidos neste processo de construção identitária, como é o caso dos editores da Sociedade Anonyma $\mathrm{O}$ Malho, composta por intelectuais bastante engajados no desenvolvimento cultural e econômico do país e que, por partilharem de uma ideologia positivista para a educação, buscavam com a publicação de "O Tico-Tico" fornecer às crianças uma formação lúdica e informal, no sentido de ampliar o repertório cultural das crianças e normatizar seus comportamentos, de modo a corrigir e moldar o caráter de um indivíduo que ainda se tornaria um cidadão - mas que ainda não o era.

O jornal escolar "Hilf mit!" tinha como corpo editorial a Associação nacional-socialista de professores que se propunha a difundir a ideologia do Nacional Socialismo de modo institucional no ambiente escolar, isto é, no ensino formal. E por se tratar de um regime político totalitário e nacionalista, toda a população tinha como seu "Vorbild" a figura do Führer, o que transparecia de modo acentuado tanto no discurso atribuído às crianças, quanto nos assinados por adultos. 
Dados os resultados mencionados anteriormente, compreendemos ser possível, de fato, observar nestes textos a construção da identidade infantil, porém não apenas no domínio dos discursos atribuídos às crianças, como também em todo o suporte midiático em que tais textos eram publicados, uma vez que, dada à fragmentabilidade com que tais identidades chegaram até nós no século XXI, os contextos sociopolíticos e comunicacionais em que ambos os periódicos foram publicados não apenas exerciam influência sobre essas construções idenditárias, como também se mostraram indispensáveis para se reconstruírem essas colchas de retalhos da imagem da criança no Brasil de Vargas e na Alemanha nazista.

Desse modo, podemos afirmar que essa complexidade interacional nos aponta para uma construção da imagem inacabada da criança brasileira no início da década de 1930, justamente por não se olhar para a criança, nessa época, como um indivíduo formado, mas sim um "vir-a-ser", o futuro da nação, e, por isso e por conta de toda a jocosidade atribuída à formação informal dessas crianças, foi possível observar um posicionamento desses indivíduos de modo mais autônomo - em termos de construção de identidade. No que diz respeito à construção identitária da criança alemã durante o apogeu do nazismo, compreendemos que a organização sociopolítica em que esses textos foram produzidos e divulgados não abria margem - nem para crianças, adultos ou qualquer grupo social - para outras ideologias e representações que fugiam aos valores vinculados à figura do Führer, Adolf Hitler. Com isso, a identidade infantil que pudemos verificar neste trabalho aponta para uma coesão identitária em torno dessa figura de poder.

Entendemos que a etapa de pesquisa que ora finalizamos constitua parte de um processo de investigação que possibilite uma melhor compreensão a respeito da construção da identidade infantil em discursos de meios de comunicação produzido por e para crianças. Tendo em vista a intrincada relação entre identidade e alteridade, compreendemos que um estudo também voltado à análise de textos escritos por adultos para o publico infantil, nos mesmos periódicos, poderia fornecer maiores pistas de como essa identidade é construída nesses veículos de massa. Além disso, a investigação de outros elementos linguísticodiscusivos poderia servir de base para uma futura pesquisa mais aprofundada em termos de estratégias discursivas. 


\section{REFERÊNCIAS BIBLIOGRÁFICAS}

ADÃO, S. M. Análise do discurso e relações interdisciplinares: Questões metodológicas de análise. In: MOSCA, L. S. (Org.) Discurso, argumentação e produção de sentido. São Paulo: Humanitas, 2006.

AMOSSY, R.; ZAVAGLIA, A. O lugar da argumentação na Análise do Discurso: abordagens e desafios contemporâneos. In: Filologia e linguística portuguesa, n. 9, p.121-146, 2007.

AQUINO, Z. G. O.; LUQUES, S. U. Propaganda político-eleitoral - um discurso em busca de legitimidade. In: Revista Linha D'água, São Paulo, n. 25 (2), p. 131-145, 2012.

AQUINO, Z. G. O. Gêneros orais, argumentação e ensino de língua portuguesa. Filologia e Linguística Portuguesa, São Paulo: Edusp. v. 17, n. 1, p. 227-248, 2015.

ARISTÓTELES. Arte retórica e arte poética. São Paulo: Ed. de Ouro, 2000.

BAKHTIN, M. M. Teoria do Romance I - A estilística. Trad. Paulo Bezerra. Rio de Janeiro: Editora 34, 2015 [1930].

BAUMAN, Z. Identidade: Entrevista com Benedetto Vecchi. Trad. Carlos Alberto Medeiros. Rio de Janeiro: Zahar, 2005.

BUCKINGHAM, D. As crianças e a mídia sob a ótica dos Estudos Culturais. In: Revista Matrizes. ano 5, no. 2. São Paulo: ECA-USP, 2012. p. 93-121.

CARVAlhO, M. M. C. de. Quando a história da educação é a história da disciplina e da higienização das pessoas. In: FREITAS, M. C. (Org). História social da infância no Brasil. 3. ed. São Paulo: Cortez, 2001.

CORREA, M. A cidade de menores - uma utopia dos anos 30. In: FREITAS, M. C. (Org). História social da infância no Brasil. 3. ed. São Paulo: Cortez, 2001.

DECCA, E. de. 1930 - O silêncio dos vencidos. São Paulo: Brasiliense, 1980.

DUCROT, O. O Dizer e o Dito. Campinas: Pontes, 1987.

FAIRCLOUGH, N. Discurso e mudança social. Brasília: Universidade de Brasília, 2001. 
FARIA, E. M. B. Argumentação infantil. Campina Grande: Bagagem, 2004.

FIORIN. Encontro de Pós-Graduandos de Estudos do Discurso. 6, Conferência de Encerramento, São Paulo: Universidade de São Paulo, 2013.

FISCHER, C. The rise of the Nazis. New fontiers in history. Manchester: Manchester University Press, 1995

GRIGOLETTO, M. Leituras sobre a identidade: contingência, negatividade e invenção. In: MAGAlHÃES, I.; GRIGOLETTO, M.; CORACINI, M. J. (Orgs). Práticas Identitárias Língua e Discurso. São Carlos: Claraluz, 2006.

HABERMAS, J. Teoria do agir comunicativo: Racionalidade da ação e racionalização social. São Paulo: WMF Martins Fontes, 2012.

IBGE. Síntese de indicadores sociais - Uma análise das condições de vida da população brasileira. Rio de Janeiro: s.e., 2013. <Disponível em: http://biblioteca.ibge.gov.br/visualizacao/livros/liv66777.pdf. Último acesso em 02/03/2016>

JUNGWIRTH, I. Zum Identitätsdiskurs in den Sozialwissenschaften - eine postkolonial und queer informierte Kritik an George H. Mead, Erik H. Erikson und Erving Goffman. Berlin: Transcript, 2007.

KEUPP, H. et al. Identitätskonstruktionen. Das Patchwork der Identitäten der Spätmoderne. Reinbek: Rowohlt. 1999.

KLEIN, W. Argumentation und Argument. In: Zeitschrift für Linguistik und Literaturwissenschaft. Universidade de Siegen. Ed. 38-39, p.9 - 57, 1980.

KOCH, I. G. V. Argumentação e linguagem.3.ed. São Paulo: Cortez, 1993.

KÜBLER, H. D. Medien für Kinder: Von der Literatur zum Internet-Portal. Ein Überblick. s.1.: Springer, 2002.

LAUERHASS JÚNIOR, L. Getúlio Vargas e o triunfo do nacionalismo brasileiro. Belo Horizonte: Itatiaia; São Paulo: EDUSP, 1996.

LEWIN, K. Frontiers in group dynamics II. Channels of group life; social planning and action research. Human relations, v. 1, n. 2, p. 143-153, 1947. 
LOPES, M. I. V. de. Pesquisas em Comunicação. 8. ed. São Paulo: Loyola, 2005.

MAINGUENEAU, D. Novas Tendências em Análise do Discurso. Trad. Freda Indurski. 2a ed. Campinas, SP; São Paulo: Editora da Unicamp; Pontes, 1993.

MATA, S. R da; MOLLO, H. M.; VARELLA, F. F. Educação e Infância em Manoel Bomfim. Anais do $3^{\circ}$. Seminário Nacional de História da Historiografia: Ouro Preto: Edufop, 2009.

MOITA LOPES, L. P. Identidades fragmentadas: a construção discursiva de raça, gênero e sexualidade em sala de aula. Campinas: Mercado de Letras, 2002, p. 29-127.

MONTEIRO, G. F. Juventude hitlerista: propaganda, ideologia e antissemitismo. Monografia (Bacharelado em História)-Universidade de Brasília, Brasília, 2013.

MUNANGA, K. Identidade, cidadania e democracia: algumas reflexões sobre os discursos anti-racistas no Brasil. In: RESGATE - Revista Interdisciplinar de Cultura n.6, p. 17-24, 1996.

NARANJO, J. (Org) Casa das estrelas: o universo contado pelas crianças. Ilustr. Lara Sabatier. Trad. Carla Branco. Rio de Janeiro: Foz, 2013.

OLIVEIRA, M. O. de. Identidade na contemporaneidade: cultura guarani. In: Revista Alceu, v. 7, n. 14, p.160-168, Rio de Janeiro: PUC, jan./jun. 2007.

PACHECO, G. B. F. Retórica e nova retórica: a tradição grega e a teoria da argumentação de Chaim Perelman. s.1.: s.e., $2007<$ Disponível no site www.pucrio. br/sobrepuc/depto/direito/pet_jur/c1 gpache.html>,Última visualização em 10/11/2016.

PERELMAN, CH; OLBRECHTS-TYTECA, L. Tratado da Argumentação. A Nova Retórica. Trad. Maria Ermantina Galvão Pereira. São Paulo: Martins Fontes, 1996 [1958].

PIAGET, J. O nascimento da inteligência na criança. Rio de Janeiro: Zahar, 1970.

PLANTIN, Ch. A Argumentação. Trad. Marcos Marcionilo. São Paulo: Parábola, 2008. 
SOARES, I. O.; VIANA, C. E. Pais, filhos \& Internet: A pesquisa TIC KIDS ONLINE Brasil 2012, na perspectiva da Educomunicação. In: TIC KIDS ONLINE BRASIL 2012. São Paulo: Comitê Gestor da Internet no Brasil, 2013.

STEINBERG, L. Adolescence 3. ed. New York: MacGraw-Hill, 1993.

TOULMIN, S. E. Os usos do argumento. Trad. Reinaldo Guarany. São Paulo: Martins Fontes, 2001 [1958].

VAN DJIK, T. A. Ideology and Discourse: A multidisciplinary Introduction. Pompeu Fabra University, Barcelona, 2000.

Discurso e Contexto: uma abordagem sociocognitiva. Trad. Rodolfo Ilari. São Paulo: Contexto, 2012.

VERGUEIRO, W. A odisséia dos quadrinhos infantis brasileiros: Parte 1: De O Tico-Tico aos quadrinhos Disney, a predominância dos personagens importados. Revista Agaquê 2.1, 1999. $<$ Disponível em: http://www.eca.usp.br/nucleos/nphqeca/agaque/ano2/numero1/artigosn1_2v2.htm.>Últim o acesso: 02/07/2014.

VOLOSHINOV/BAKHTIN. Marxismo e Filosofia da Linguagem. Trad. do francês de Michel Lahud e Yara Frateschi Vieira. 6. ed. São Paulo: Hucitec, 1992 [1929].

WERMKE, M. Duden - Deutsches Universalwörterbuch. Mannheim und Leipzig, Deutschland: Dudenverlag, 1996.

WODAK, R. Do que trata a ACD - um resumo de sua história, conceitos importantes e seus desenvolvimentos. In: Linguagem em (Dis) curso. v4. Santa Catarina: Universidade de Santa Catarina, 2004. $<$ Disponível em http://www.portaldeperiodicos.unisul.br/index.php/Linguagem_Discurso/article/view/297/313 > Último acesso: 10/11/2016.

WOLF, M. Teorias da Comunicação. Trad. Maria Jorge Villar de Figueiredo. 5. ed. Lisboa: Presença, 1999. 


\title{
APÊNDICE
}

\section{${ }^{67}$ Tradução dos textos da Revista "Hilf mit!"}

\author{
Festa da colheita em Landjahr - H1
}

(Outubro de 1935, pág. 6-7, Erntefest im Landjahr)

"Neuendorf nunca festejou uma colheita como a de 1934". Confirmou claramente Heini, o menino da cidade grande. Sua avó guardou uma longa carta sobre isso, numa caixinha de ébano com muitos outros textos de seu neto. $\mathrm{E}$ aos domingos, quando ela tem um tempo tranquilo, lê os relatos de Heini, que escreve com uma letra tão bonita e redonda que ela mesma acredita estar em sua vilazinha brincando entre os campos e as lavouras.

Cuidadosamente, a Senhora Eschenhagen alisa o papel enrugado com suas mãos calejadas pelo trabalho, põe os óculos e se prepara para ler. De lá, ressoam da rua chamados e música. Ela quer espiar, mas não vê nada além do quintal cinzento, dos telhados empoeirados e um pedacinho do céu. Então esboça um sorriso em seu rosto enrugado. Lembra-se que hoje eles festejam a colheita. Também nas grandes cidades as pessoas estão felizes e pensam nos camponeses que lhes fornecem o pão de cada dia.

Mas o seu Heini! Ele está lá fora, em Neuendorf, também hoje, como há um ano. E ela lê pela $5^{\text {a }}$ vez a carta de seu neto. "Aqui a primeira", ri ela: "Queridíssima avó! Na quartafeira, chegamos em Neuendorf. Eu tenho muito o que fazer, pois estabelecemos nosso acampamento numa casa antiga. Por isso, escrevo hoje apenas algumas linhas. Eu estou tão feliz! Nosso lar fica sobre a montanha da vila. Eu posso ver todo o panorama do oeste do campo até a floresta. Na vila, há muitas casas térreas e uma igreja fortificada de granito. Em breve, eu devo ir trabalhar em uma fazenda. Mas antes, nós precisamos aprender a Ordem. E imagine só: temos um uniforme da Juventude Hitlerista! Sobre o braço esquerdo está escrito: Landjahr. Todos nós 60 o vestimos. Nosso Führer se chama Kurt, um excelente rapaz! Por hoje é só. Está soando o toque de recolher. Saudações cordiais do seu neto Heini.

De fora, a música tocava cada vez mais próxima. A Sra. Erschenhagen pergunta a si mesma se deve ir no fluxo das pessoas. Seus pés mal a carregavam. Então seu olhar repousa sobre a carta mais longa, que Heine escrevera-lhe. Ela se tranca em seu sótão para lá ficar e

\footnotetext{
${ }^{67}$ As presentes traduções buscaram manter a estrutura dos textos originais. Por se tratarem de textos escritos presumivelmente por crianças, optamos por não apagar marcas linguísticas que, na Língua Alemã indicam uma escrita mais infantil.
} 
ler sobre a festa da colheita em Neuendorf. "Nunca Neuendorf festejou uma colheita como esta. Pode acreditar em mim! Isso se deve também ao fato de que nós, Jovens do Landjahr, termos ajudado na festa.

Preparamo-la voluntariamente a semana inteira. Kurt, nosso chefe do acampamento, chamou para nossa sede o chefe dos camponeses do leste. Ele deveria nos falar o que eles fariam na vila no domingo. O Führer dos camponeses não sabia, no começo, o que falar. Ele disse que alguns camponeses não queriam participar, pois eles não poderiam comemorar sua colheita em setembro como antes. Então nós chamamos o professor e um velho camponês. Ele contou o que ouvira de seu pai e das antigas festas de colheita. Ele conhecia ainda um antigo ditado sobre o tema e mostrou como eles, uma vez, fizeram uma guirlanda de colheita. Então Kurt disse: 'Meninos! Nós vamos fazer um projeto como este!' Então ele se sentou junto com os três homens e logo já estava pronta uma longa lista de afazares. O plano foi estabelecido entre todos. O que nós mesmos faríamos não foi revelado. Nós trabalhamos duro nas horas da tarde, fizemos a coroa da colheita, pintamos cartazes e muito mais. No domingo de manhã, fomos todos à igreja. Havia muita festa quando marchamos pelo antigo portão da fortaleza. No altar, estava montado um buquê de cereais e na bacia de batismo havia uma cesta com frutas do outono. Isso foi uma oferenda das pessoas mais pobres da região. Nós também contribuímos com o nosso jardim de casa. Começamos a canção com "Agora agradecei todos a Deus".

À tarde, às 2 horas, começou a marcha à festa de campo em Heldenheim. Nós pudemos marchar na primeira fila. Na comissão de frente, ia o nosso grupo da fanfarra. Então vinha a guirlanda, que os meninos carregavam nos estandartes. Um carro seguia-os com os dizeres: 'O Landjahr ajuda aos camponeses!' Um grupo das pás juntou-se. No carro seguinte haviam dois camaradas, que mostravam nossos próprios produtos do Landjahr: enormes morangas, mas também nossos gansos, ovelhas e pombas. Os moradores de Neuendorf riram disso. Eu cavalguei sobre o cavalo da minha fazenda com a comitiva. Depois seguiam o Jungvolk ${ }^{35}$, a Liga Federativa de Meninas e o restante dos meninos do vilarejo. A escola estava em um carro decorado com guirlandas. Então vinham os cortadores e as cortadoras e a capela da vila. Os moradores tocavam principalmente três instrumentos: trompete, clarinete e violino. Um belo carro acolchoado trazia os mais velhos camponeses e camponesas. O encerramento foi feito um carro da colheita, com o último maço, o "Velho". Isto é, um espantalho, que fora feito na plantação da última colheita. Era o dia mais ensolarado do ano. Você pode imaginar, querida vovó, como nós vibrávamos de alegria. Mas agora o gramado da festa! Nosso Kurt realizou um velo discurso para todo o vilarejo reunido. $\mathrm{O}$ chefe dos camponeses do leste nos 
convidou em seguida para um café com bolo. Mas nós não tivemos muito tempo para nos sentar. Nossa guirlanda da colheita foi trazida de seu alto mastro com um cesto envolto por todos os tipos de presentes. E então gritaram: "Pau de sebo". Nós subimos nele com os meninos da vila durante competição. Eu conseguir pegar no topo um belo caderno de anotações. Erich fizera uma besta. Com ela nós atiramos nas galinhas de madeira em uma haste, que nós mesmos havíamos cortado. Eu acertei uma ave e ganhei o terceiro prêmio: uma gaita. - Numa competição nós, meninos da cidade grande, pudemos medir nossa força com os meninos do vilarejo. Nós nos saímos muito bem, porque nós havíamos praticado esportes por meio ano. As meninas me viram na corrida com saco de batatas e na corrida de ovo. Eu, porém, tive pouco tempo para assistir, porque tinha que ajudar com as marionetes. Com uma tenda, nós montamos um teatro. Oh!, como os moradores riram quando nossos próprios bonecos apresentaram "Sonho de uma noite de verão!". Algo muito engraçado que o Berhard criou. Houve um sarau com imagens, que traziam a legenda: "O fantasma assustador em Klein-Meckersdorf". Isso deixou os moradores de Mecker de cabelo em pé. Então uma estrondosa trompete soou. Todos se dirigiram ao alto-falante, que fora trazido para o local da festa. Imagine só: Nós ouvimos o Führer! Adolf Hitler falava de Bückenberg com todos os camponeses ao mesmo tempo, e isso foi como se ele estivesse entre nós. Sentamonos bem quietinhos sobre o chão, entre os moradores de Neuendorf, e essa foi a vista mais bonita do dia. Até os camponeses, que no começo não queriam comemorar, ficaram felizes e orgulhosos do que eles conseguiram. Quando o sol se pôs, nós fizemos um círculo em Heldenhain. A fogueira queimava e nós falamos com o coro: "A benção da Terra!". Então: um minuto de silêncio. Nós pensávamos nos herois mortos na Guerra Mundial. Então tocou-se uma música de marcha e, à luz da tocha, marchamos de volta para o vilarejo..."

A senhora Eschenhagen deixou sua mão cair com a carta. Ela olhou para fora da janela. Mas ela já não via mais os telhados cinzas e as chaminés da grande cidade. Diante de seus olhos, ela via o campo da festa de Neuendorf, onde seu Heini, também nesse domingo, estava.

Em silêncio, ela disse para si mesma: "Ele voltou para o vilarejo. Ele tomou o ofício para si. As ferramentas do campo fizeram isso com ele. Ele quer ser um ajudante dos camponeses - do seu modo. Heini, assim você retornou para os passos de seu bisavô. Ele te segue logo atrás. Que Deus te abençoe, meu menino!

R. P. Mettke 


\section{Palavra do Füherer}

Todas as oscilações são suportáveis no final, todos os golpes do destino são superáveis, se existir uma agricultura saudável.

Enquanto um povo puder contar com a agricultura, será criada dela cada vez mais e mais força.

(Do discurso aos alemães agrícolas em 5 de abril de 1933) 


\section{Meninas no acampamento - $\mathrm{H} 2$}

(Outubro de 1935, pág. 14-15, Mädel am Lager)

(ao ar livre em Mäkische Heide)

“... E sobre nós, a bandeira estala e trepida junto. Já marchamos há duas horas. Vinte meninas de Berlim. A cidade grande fica para trás de nós, com seus caixotes de pedra, com sua fumaça e fuligem. A escola, a fábrica e o escritório estão esquecidos, pois à frente há uma semana de companheirismo, uma semana cheia de esporte e formação espiritual. Nenhuma de nós está cansada da longa marcha. Em breve nós já deveremos ter alcançado nosso destino, em Märkische Heide . Mais uma última música.

'Nós somos jovens, o mundo é livre!' Nossos olhos procuram o destino. Lá está, em Kiefernwald, o nosso abrigo secreto. Um comando: Pelotão - Sentido! Descansar!

Nós o alcançamos.

\section{Horas de companheirismo}

Nós já estamos aqui há quatro dias. Todo dia brincadeira e esporte. À noite, nós cantamos músicas e contamos umas às outras sobre a nossa vida na cidade. Ontem, Ruth, nossa Führerin relatou sobre os anos de batalha. Ela participou, em outubro de 1932, no Reichsjugendtag. Pela primeira vez na história da Alemanha, assim narrou Ruth, centenas de milhares de meninos e meninas ficaram conhecidos pela Alemanha e por nosso Führer, Adolf Hitler, numa poderosa manifestação. Todos que eram, naquela época, nacionalsocialistas, tinham isso forte dentro de si, porque o mágico patriotismo invadia não apenas os homens da SA ou SS, mas também meninos e meninas da Juventude Hitlerista. 'Nós ficamos todos juntos, dissera Gerda, para que nosso povo pudesse se tornar forte e unido novamente. Não temíamos ninguém e sempre permanecíamos unidos, na alegria e na tristeza'. Nós, porém, que só depois encontramos o reconhecimento ao poder de Adolf Hitler, queremos tomar nossos camaradas dos tempos de luta como modelo e, assim como eles anteriormente, permanecer juntos com os outros em companheirismo. Seja menina ou menino, ou estudante, ou aluna do ensino industrial ou datilógrafa. Somos todos alemães - um único povo. Nosso acampamento aqui em Märkische Heide é, porém, um pequeno fragmento do grande companheirismo do povo. 
Os meninos, como nós sempre lemos em seus relatos de viagem, têm um medo muito grande dos serviços de cozinha e encaram-no como um castigo. Conosco, isso era totalmente diferente, e Ruth tinha que se esforçar para separar os afazeres. Com isso, o trabalho não era tão simples. Quem era do serviço de cozinha, precisava acordar uma hora mais cedo, para que as demais recebessem seu café-da-manhã na hora certa. Preparar sanduíches para vinte meninas famintas, isso é um trabalho cansativo. Então, algumas de nós logo se arrependeram de sua precipitada prontificação para o trabalho, quando ninguém mais queria fazê-lo de novo.

O que tinha para comer? Vocês vão se surpreender. Apenas uma vez, ao longo de toda a semana, tinha salsicha e ervilha. De resto, era macarrão de leite, gulasch, arroz com caldo de carne, couve e sopa de batata. Os meninos ficariam, com certeza, mordidos de inveja se tivessem visto. Tudo sempre esteve delicioso. Até uma vez, em que nossa amiga queimou o arroz doce.

Geralmente, à noite, nós cantávamos bastante. Ruth conhecia muitas músicas folclóricas bonitas, cujas melodias ela tocava para nós. Aprendemos uma enorme quantidade de novas canções com isso, pois a nossa Führerin nos contava sempre em seguida como essas músicas haviam surgido e como são cantadas. Nós não as conhecíamos. Agora gostamos muito de cantá-las.

\section{$\underline{\text { Meninas em serviço }}$}

Vocês, que não querem participar da vida e agitação da Federação das Meninas, sabem o quão belo é um acampamento como o nosso? Quem já viveu ao ar livre ao menos uma vez com outras meninas, camaradas, num acampamento repleto de esporte e brincadeiras, jamais se esquecerá disso. Foram belos momentos, sinceros e serenos. Repletos de espírito de companheirismo. Esse companheirismo que não se pode descrever, apenas vivenciar. Aqui nós nos sentamos uma ao lado da outra, meninas de todas as origens do nosso povo, meninas do leste, norte, sul e oeste de Berlim, e somos todas uma só: meninas alemãs, que na juventude hitlerista, com atitude e detenção devemos estar ao lado do nosso povo.

Algumas de nós já aprenderam a entender no acampamento porque estão em nossa Federação de meninas e o que nós queremos. Em comunidade com outras, elas ficam agora conscientes em relação à bandeira e flâmula da nossa federação enquanto meninas em serviço da Alemanha. 
Hoje é o último dia em Märkische Heide. As mochilas estão limpas e já feitas, as cabeceiras das camas, higienicamente preparadas. Nós estamos em pé ao redor da mesa e, pela última vez, damo-nos as mãos e cantamos em despedida: "Ode ao bom poder..."

Amanhã cedo, às seis horas, um som de apito estridente nos chamará, e então vai-se para casa. De volta à cidade grande, de volta ao trabalho.

Até o próximo acampamento.

W. W.

Mãe, você está ouvindo a canção exultante,

Pelas quais os jovens grupos estão passando?

Ela me chama, ela me atrai,

Ela não me deixa!

O mundo é tão vasto -

E a saudade é tão grande.

Mãe, eu queria estar lá!

Mãe, você ouve as bandeiras chacoalharem, que palpitam sobre as Meninas de Hitler?

Canta-se estranhamente no meu coração.

Canta-se tão amigavelmente, tão cheia de coragem.

A bandeira chama

E atrai tão bem.

Mãe, eu queria estar lá!

Mãe, eu não posso ficar de fora,

Ouça o grito do meu sangue!

Os corações jovens queimam como chamas

E cantam juntos

E juram juntos

Todos, que vem de sangue alemão,

Mãe, todos estão lá! 
Nós queremos participar - H3

(Outubro de 1935, pág. 30-31, Wir wollen mithelfen)

Cartas de alunos sobre a Brigada de Inverno de 1934/35

\section{Uma equipe de meninos recolhe papeis.}

Foi no inverno passado. Nós estávamos contentes e animados com nosso novo abrigo, por nós mesmos decorado, e cantávamos valorosas canções de serviçais da pátria e de viagens. Nosso cantinho era simplesmente primoroso, não se podia falar o contrário. Nós tínhamos um antigo estábulo, o qual fora abandonado há muito tempo por seu dono, devido a sua "incapacidade". Com a ajuda de uma monstruosa quantidade de água, muitos rodapés e papeis de parede cortados, deu-se a ele uma aparência habitável. À noite, já estava perfeitamente agradável.

De repente, porém, o bom humor foi interrompido por um alto barulho. Kurt e Erich haviam se pegado pelos cabelos. "Mas você já teve horas de serviço ontem e por isso foi responsável pela limpeza. Como isso está até agora? Ali estão jogados todos os jornais velhos da restauração. Você acha, talvez, que eu vou arrumar tudo isso, só porque ontem você estava muito preguiçoso para seu serviço?” Irritado, Kurt empurrou com o pé contra uma pilha de jornais, que estava num canto da casa. “Onde devo, então, levar essa bobagem?” Devolveulhe Erich furioso "Você acha que eu estou montando um brechó de papeis velhos?

Sem ser notado, nosso Führer do acampamento dos meninos, Hans, entrara. Erich repetiu mais uma vez, resmungando sua frase com brechó de papeis velhos. Então Hans disse alto: "Nada má a sugestão".

Naturalmente, todos nós levamos um susto, quando nosso Führer apareceu atrás de nós. "Prestem atenção", disse ele e apontou para a pilha de papel de jornal. "Isso ainda não é suficiente, isto deve aumentar ainda mais". Kurt, que em outro acapamento ficara com o serviço de quarto, fez um olhar horrorizado. "Por que ainda mais?". "Isso vocês devem ouvir agora! Então - nós vamos coletar agora jornais, depois os venderemos todos à reciclagem de papeis velhos. Porém, vamos transferir todo o dinheiro à Brigada de Inverno." Isso nos chamou bastante a atenção. Todos nós concordamos com isso, logicamente. No outro dia, os moradores do abrigo viram pacotes pesados entrando e saindo da casa. "Para onde vocês querem ir com todo esse papel de jornal velho?" perguntavam alguns incrédulos. Nós, porém, continuamos a carregar com fervor as pilhas e pilhas de jornal em nosso lar, no qual não havia mais nenhum papelzinho. Então nós carregamos o papel sobre um carrinho de mão. E de lá 
ele ia para a cidade, na reciclagem de papeis. Vinte marcos, foi o que conseguimos. O catador nos deu mais dois marcos quanto descobriu para que nós havíamos os coletado.

No grupo regional do NSV todos ficaram surpresos e se alegraram enormemente. Agora há pendurado em nosso lar um grande quadro do nosso Führer, que o chefe do Grupo Regional nos presenteou e nele escreveu: “Aos meus jovens camaradas, por seus serviços á Brigada de Inverno."

Werner S.

\section{Garrafas de Vinho para a Brigada de Inverno}

Primeiro, todos eles riram quando eu contei na sala de aula. Mas depois, a maioria disse: "Ei, isso é simplesmente sensacional. Na próxima vez, vamos fazer isso também com as garrafas de vinho para a Brigada de Inverno." Nosso professor nos apresentou na aula de alemão uma longa palestra sobre a comunidade popular e a Brigada de Inverno. Ele disse que todo alemão, seja homem ou mulher, menino ou menina, deve apoiar essa obra do Führer. Então, eu fui para casa e fiquei pensando em também fazer algo bacana para a Brigada de Inverno. Mas o que eu deveria fazer? Dinheiro eu não tinha, pois meu pai não podia me dar mesada, já que ele é um simples peão de obras da Reichesbahn alemã. Então eu me lembrei que em nosso porão há muitas garrafas antigas de vinho e de cerveja. Nós temos, em Kaulsdorf, uma pequena colônia de hortas ao livre, um pedacinho de terra (a isso se chama "Horta Urbana"). Meu pai plantou lá sementes de groselha-espinhosa e groselha-negra. As frutas são prensadas em um vasilhame para destilar. Depois viravam, mais tarde, vinho de groselha. Mas meu pai precisava de muitas garrafas de cerveja para estocar o vinho. Ao pedido de me dar algumas garrafas, meu pai perguntou: "Para que você precisa delas? O que você vai fazer com o dinheiro?" Então, eu respondi: "Eu quero fazer algo pela brigada de inverno". Por conta disso, meu pai me deu a chave do porão e então disse: "Nós mesmos temos só um pouco, mas se pudermos, também vamos ajudar!” Vinte garrafas meu pai me deu, e consegui dois marcos e cinquenta com elas. Com orgulho, levei o dinheiro ao posto da NSV e depositei. Meu pai pendurou o recibo em seu armário, pois ele se regozijou comigo.

“Olha só, rapaz," ele me disse, "isto é que é socialismo de fato. Não fazer doações e dar esmolas, mas sim dividir os sacrifícios com o compatriota alemão. Se todos os seus jovens camaradas pensarem assim e agirem como você, a Alemanha se tornará melhor.”

Kurt W. 
Porque minha mãe disse que eu deveria escrever aos senhores, tenho que finalizar essa carta agora. Todos nós fizemos algo para as festividades de Natal, e essas coisas devem ser entregues à Brigada de Inverno, para que outros também tenham alegria. Nós somos três irmãs e eu sou a mais nova. Minha mãe também faz parte da NSV e vai às casas para conversar com as pessoas. Lá ela ajuda de várias maneiras, e nos contou que, às vezes, há grande alegria em coisas pequenas, que não tem nenhum valor. Alguns têm muito e jogam coisas fora, e outros são pobres e podem precisar delas ainda. Eu sempre tenho que vestir o que já não serve mais para as minhas irmãs. A minha mãe sempre deixa as coisas muito bonitas para me servirem, me faz um novo colarinho, mas bem alto, para que pareça diferente. Quando eu estiver maior, poderemos não precisar mais delas. Mas ainda é possível fazer mais alguma coisa com isso. Nós tínhamos uma velha jaqueta de lã, que nós crianças queríamos colocar na sacola de farrapos. Mas nossa mãe não nos permitiu isso. Nós tivemos que desfiar a jaqueta, já que mamãe não tinha tempo para isso. Então minha irmã tricotou a partir da jaqueta, sapatos para crianças pequenas - crianças tão pequenas que nem podem andar ainda, que ainda ficam no carrinho -, para que não congelem seus pés. E eu costurei aparadores de panelas, porque eu ainda não sei tricotar. Mamãe cortou os aparadores de panelas e eu então costurei com linhas coloridas. Eu queria, inicialmente, fazer pequenos dentinhos de rato de crochê, mas não deu certo. Mamãe disse que sou muito pequena para isso, eu devo esperar até o próximo ano, e as pessoas já estão muito contentes por meus aparadores de panela. E depois, nós dissemos às outras crianças em nossa casa que elas também deveriam ajudar. Então costuramos, tricotamos e fizemos crochê com pequenas sobras de toda a casa, e levamos à Brigada de Inverno.

Minha mãe disse que todas as crianças na Alemanha devem fazer o mesmo e por isso eu escrevo a vocês. Heil Hitler!

Käthe L.

As cartas aqui presentes de seus camaradas mostram a vocês o que outras crianças fizeram para a Brigada de Inverno. E vocês? Também nesse inverno milhões e milhares de compatriotas pobres deverão ser ajudados. Como vocês querem ajudar nisso? Pensem bem nessa pergunta e então compartilhem conosco suas sugestões. Vocês podem ter sorte, porque nós queremos premiar as melhores ideias. Cada um deverá receber de cinco a vinte marcos por sua obra. Agora pensem em algo bastante especial, não algo que todos já tenham feito, mas algo bem inovador. Depois vocês compartilham isso conosco em uma carta. 
Vocês também podem receber um prêmio de outras formas. Alguns de vocês possuem câmera fotográfica, talvez tenham ganhado uma em um concurso anterior de cartas de "Hilf mit!". O diretor da Brigada de Inverno, Hilgenfeld, pede a nós, para que os jovens alemães enviem fotos da Brigada de Inverno. Em todo o canto será trabalhado neste inverno para a Brigada. O carro que recolhe peças de roupas, tecidos, etc., passará pelas ruas, serão coletadas caixas de tudo o que foi costurado e tricotado em casa. Certamente, alguns jovens já terão feito coisas muito bonitas e trazido aos pontos de coleta da Brigada de Inverno; então haverá muito o que fotografar. Enviem-nos as imagens, as melhores serão igualmente premiadas em dinheiro.

Todas as cartas devem conter o seguinte endereço: ao concurso de "Hilf mit!" para a Brigada de Inverno, Berlim Tempelhof, Rua Alboinstrasse 21/23. - As datas de envio vão de $1^{\circ}$ de outubro a 30 de novembro de 1935. As melhores sugestões serão publicadas. Todas as cartas, inclusive as fotos, devem conter nome, sobrenome, idade e endereço completo (com código postal) do remetente. Cartas que não preencherem esses requisitos não serão consideradas. Todos envios ficarão como propriedade da editora e não serão devolvidos. 
Cedros de Natal em Usambara - H4

(Dezembro de 1935, pág. 78-79, Weihnachszedern in Usambara)

Em nossa antiga colônia teuto-africana oriental é agora época de calor. O sol fica quase que verticalmente no céu, de modo que não se pode encontrar a própria sombra, vestem-se as mais leves roupas de verão, as rosas florescem e os morangos ${ }^{36}$ amadurecem. Apesar disso, dependura-se, no primeiro domingo de advento, a coroa verde em cada casa alemã, e as quatro pequenas luzes ${ }^{37}$ ajudam a lembrar, que também na África haverá Natal.

Onde há crianças, o período de advento é cheio de música e cheio de alegria. Eu vivenciei a festa nas proximidades da maior escola alemã do país, a Friederich-vonBodelschwingh-Schule. Já de manhã, antes das 7 horas, tocavam nossas belas canções de advento sobre a Montanha de Usambara iluminada pelo sol. E quantas surpresas de Natal foram boladas com amor. $\mathrm{O}$ que poderia ser mais legal que fazer uma besta de madeira para $\mathrm{o}$ irmão de casa? Construir para a irmã uma flauta de bambus; a mãe ganhou um vaso suspenso e anéis de guardanapo finamente decorados, todos do mesmo material. Bambus crescem em grande quantidade no campo. A irmãzinha de três anos ganhou um peão de abóbora seca, que fica girando e roncando, como todo bom peão. Mas o que presentear ao pai? Essa é uma questão tão difícil na África oriental como é na Alemanha. Talvez selos postais que se tenha trocado com outros? Comprar não se pode, pelo simples motivo de não haver lojas.

Em todas as casas alemãs são feitas pfeffernüsse ${ }^{38}$, brancas e marrons. Lá surgem Papais Noeis e pinheiros, estrelas e kringel ${ }^{39}$, naturalmente tudo com receitas antigas de casa. Não lhes afeta a beleza que, ao invés de amêndoas, tenhamos que usar, na maioria das vezes, amendoins das próprias colheitas para decorar. No lado de fora, sob as frondosas árvores, a massa é sovada cortada e colocadas sobre as placas; então vem o criado e a coloca no forno e se surpreende com as notáveis forminhas.

Latas de bolo, quase que totalmente feitas à mão, são enchidas; mas então da onde vem o pinheiro? Ele não existe! Eu consigo ver suas caras decepcionadas. Mas, se não há nenhum pinheiro de verdade, há um jeito de conseguir. Um cedro deve virar a árvore de Natal! Ele também tem até algumas pequenas semelhanças com a sua irmã alemã: ele é verde e tem vários ramos do mesmo tamanho espalhados em seu tronco. No dia 23 de dezembro o nosso jardineiro negro, Asumani, nos acompanha à floresta, convocado com seu serrote de poda. Nós ficamos um bom tempo procurando, até encontrarmos um bom cedro, que possa se tornar uma árvore de Natal. Asumani o derruba e o traz para casa. Lá fora, na parede da casa, ele é exposto; todos podem vê-lo, até as crianças, antes que ele se esconda na sala decorada para o 
Natal. De repente, Christa e Ruth irrompem com altos gritos de alegria. O criado vem a caminho e traz pacotes de sua terra natal, dois sobre a cabeça, o terceiro na mão. O que pode estar lá? Pode-se senti-lo ou cheirá-lo, mas sem sucesso.

Finalmente a Noite Santa chegou. Enquanto, na sala de Natal, o cedro africano se tornava numa árvore de Natal com velas e fios prateados, as crianças são mandadas ao jardim para colher muitas, muitas flores.

Às 18 horas, antes do breve crepúsculo ${ }^{40}$, batem os sinos de natal sobre a montanha e o vale, chamando com alegria e vigor. Quem não quer segui-lo? Isso faz parte do culto ${ }^{41}$, com uma festa de Natal! O caminho é longo e vai ladeira acima, e é quente também. O criado selou o jumento-mascote, mãe e crianças cavalgam. A escuridão chega rapidamente. Nós vemos a igreja pintada de branco brilhando entre as árvores. Às $19 \mathrm{~h}$ já é noite escura. O culto começa. Dois imensos cedros com velas em chama estão em cada lado do altar, assim como em casa. O grande templo de Deus lotou-se nas últimas horas com negros e os poucos alemães da região. Nas fileiras sobre o chão, as crianças se sentam lado a lado. Sobre suas negras peles em seus olhos iluminados, reflete-se a luz das velas. Eles também sabem algo sobre o Natal! Com a voz clara, eles cantam: "Vossa criança vem..." E " Oh, você feliz...", naturalmente não muito nítido, mas sim em sua língua tribal quilombola. Então, caem por fim gotas de chuva sobre o teto de zinco. O trovão ruge; o barulho é tão alto, que nenhuma palavra mais pode ser ouvida; soam como tambores de fogo. por sorte a saudação em forma de tempestade passou rápido. Enquanto o coro com trombetas tocava lá fora as canções de Natal, começamos o caminho de volta para casa. Que vista adorável! Nós nos mantivemos em curso: através da noite escura, milhares de luzinhas se moviam, como bolas incandescentes; elas se espalhavam no alto e nos vales; nós sabíamos que eram frequentadores da igreja, que voltavam para casa, como a gente.

E então nós paramos sob a árvore brilhante, cantamos mais uma vez nossa canção de Natal, abrimos nossos presentes e pensamos sobre nossos amados na Alemanha.

Eu sei que há nessa noite muitas pessoas com saudades de casa! Só não deixamos perceber isso.

Olivia Alm

Nossos pais fazem brinquedos - H5

(Dezembro de 1935, pág. 80-81, Unsere Väter machen Spielzeug) 
Essa foi uma linda festa de Natal para nós seis irmãos, quando nós encontramos sob a árvore de Natal uma tenda de marionetes com várias marianotezinhas escondidas. E essas coisas não foram compradas numa loja; nosso pai as cortou, pintou e montou, enquanto nós estávamos dormindo profundamente. E com que delicadeza ele fez isso! Não falta nenhuma orelha ou dedo, toda marionete tem força e expressão. Com quanto amor nosso querido pai elaborou essa tenda. Por semanas, ele se alegrava noite a noite, quando pegava seu canivete e começava a cortar. Todas as vezes, ele pensava: Ah! Eles vão se surpreender quando estiver tudo pronto sob a árvore de Natal. - E nós nos surpreendemos! Nós nos alegramos neste Natal como em nenhum outro.

Um brinquedo desses, que nosso pai ou nosso irmão mais velho nos fez, é algo muito especial, isso não se pode comprar em nenhuma fábrica, só há um desse em todo o mundo.

$\mathrm{Na}$ Alemanha há, agora, muitos pais que se alegram em fazer brinquedos e outros objetos. Não se pode nem imaginar quantos pais desse tipo há. Agora, a Secretaria da Cultura do NS está tentando reunir, em toda a Alemanha, brinquedos e todas outras coisas possíveis, que não foram feitas por especialistas, mas sim por leigos, pelo simples prazer em produzi-los. Muitas coisas foram enviadas, com as quais foi possível montar uma exposição. Ela se chama "Criações leigas alemãs". Esses dois objetos dessas fotos impressas nessa página vêm dessa exposição. Uma pena que nem todos vocês possam visitá-la. Alguém pintou lá pequenas imagens em um livro de figuras reunidas para crianças. Um outro pai montou um diveritdo carrossel, que é mostrado aqui. Com que fineza ele fez o teto e os pilares, e o carrossel tem todo um maquinário para ser colocado em movimento. $\mathrm{O}$ carrossel tem sempre um realejo, que não poderia faltar aqui, é claro; por isso foi colocado uma caixa de som com um disco. Engraçada também é a trupe de animais. Como o gato curva suas costas e levanta sua cauda, como se ele quisesse fugir de um curioso cão de três olhos. E a carroça não é maravilhosa? Quando vocês olham demoradamente para a roda, vocês reconhecem na hora um rosto; dois olhos atônitos, uma boca também atônita, e o cubo fica ao mesmo tempo no lugar de um lindo narizinho. Ela foi feita por um camponês simples das Montanhas do Rhön.

Até o divertido quebra-nozes deve sua existência a um camponês, que esculpiu e montou essas coisas lindas numa longa noite de inverno. Quando a criatura vai morder, faz uma cara feia. Assim o agricultor esculpiu totalmente sozinho para seu quebra-nozes uma expressão malvada - Sai a noz que ele tinha na boca! A sua casca fica implacavelmente presa. Um quebra-nozes desse tipo não leva as coisas muito na brincadeira. Logo é Natal de novo e, como em todos os anos, o quebra-nozes enfrentará seu cruel regimento. Não deixe para ele 
quebrar todas as nozes; se vocês separarem cuidadosamente com uma faca as cascas de nozes, as duas metades ficarão intactas. $\mathrm{O}$ miolo vocês comerão rápido, mas as cascas poderão ser fechadas novamente com um pequeno arame. Se amarrarem mais algumas cascas de noz vazias como essa, vocês terão um chocalho de crianças.

\section{O pai faz artesanatos}

À noite, quando a gente está na cama, algo é produzido no quarto do meu pai. Faca, serrote, martelo, tábua ficam sob a luz da lâmpada. E agora vamos para a broca, esculpir. Um barulho! - alguma coisa caiu! Eu quero olhar pela fechadura o que meu pai está fazendo ali. Todo ano. Todo ano, pelo que eu me lembre, ele inventa algo especial. Sim, o mais bonito do presente, está em sua mão. 


\title{
Transcrição dos Textos de "O Tico-Tico Mundano"
}

\author{
O Tico-Tico Mundano - T1 \\ (O Tico-tico, Ed. 1475,10 de janeiro de 1934, p. 25)
}

\section{NO CINEMA...}

Para fazer um film contractei as seguintes meninas e meninos da rua José Bonifácio: Vanda, a loura Constance Bennett; Yeda, a graciosa Anita Page; Lygia, a sympathica Rosita Moreno; Aida, a linda Jannette MacDonald; Marietinha, a ingenua Sylvia Sydney; Valma, a alegre Clara Bow; Maria Seli, a fascinante Norma Shearer; Rachel, a inesquecivel Rachel Torres; Georgina, a adoravel Joan Crawford; Jorge, o nosso querido patricio Raul Roulien; Fernando, o genial John Barrymore; Henriquinho, o romantic Ramon Novarro; Walter, o engraçado Buster Keaton; Luiz, o athleta Philippe Holmes; Urbano, o formidavel Etam Lawrell, e eu a diretora - I. C. B.

Para organizar um film em Magé, contractei os seguintes amiguinhos magéenses: Carmelia, a deslumbrante Shirley Grey; Luiz, o Heinz Rühman; Zelia, a interessante Frances Dee; Jorge, o conquistador John Gilbert; Ondina, a galante Diana Wyniard; Maria S., a Claudette Colbert; Benjamin, Herbert Marshal; Glorinha A., a linda Joan Crawford; Noemia, a sympathica Verena Illie; Maria Elise, a encantadora Lona André; Lourdes Assumpção, a irresistivel Leila Hymans; Cesar, o terrivel Monte Blue; David, o aventureiro Buck Jones; Alcina B., a graciosa Zazu' Pits; Almir, o elegante Richard Arlen; Eulalia P., a Sylvia Sydney, e eu o encantador Artecip Satier.

Levantou vôo de regresso ao Brasil, o avião Siris, trazendo um casal de astros que vieram interpretar um film. Eram elles: Antonio S. da Cunha, o Douglas Fairbank e a Maria Lelis, a Joan Crawford. Na travessia tiveram de enfrentar os seguintes meteóros: Liliana, a chuva; Justino o relampago; Nelson, o trovão; João Paulo, o vento. Logo surgiu radiante Carlos, o sol. Sem mais embaraços, encontraram-se com Humberto, o dia; Dula, a noite; seguida de Ruth, a lua; Olavo, o Plutão; Nizia, a Jupiter, e Florinda, a Sirius. Depois de passarem o arco-iris, Roberto; chegaram salvos no Campo de Affonsos, onde os esperavam os seguintes astros: Nair, a Norma Shearer;Elisa F., a Kay Francis; Regina a Minna Gambel; Carlos, o Tom Mix; Izabel, a Constance Bennett; Gabriel, o Haroldo Lloyd, e eu a Jean Harlow. 
'Manoel Sampaio Brilhante, de 3 anos de idade, filho do Sr. Alvaro Brilhante e D. Marieta Sampaio Brilhante, residente em Nova Iguassu' (E. do Rio). [legenda da foto de uma criança segurando um violão]

\section{A distribuição dos premios do Grande Concurso da Independencia}

A photographia acima foi tirada na succursal d'O TICO-TICO, em São Paulo, quando ali se procedia à entrega dos premios do Grande Concurso da Independencia aos contemplados no importante certamen. Os premiados foram os seguintes leitores: Haroldo

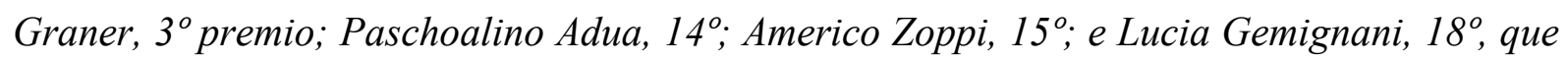
figuraram na companhia do Dr. Plínio Cvalcante, director da succursal d'O TICO-TICO. [legenda da foto das crianças vencedoras do concurso]

\section{NA GAIOLA...}

Estão na gaiola os seguintes alumnos do Collegio N. S. Aparecida: Aurea, uma araponga; Alvaro, um papagaio; Damião, um corió; Carmita, uma sabiá; Lourdes, uma cigarra; Zezé, um canário; Antonio, um chorão; Zeferino, um pica-pau; Lourdes V., um bico de lacre; Ernesto, um vira-bosta; Antonio P., um pardal; Véra, uma andorinha; Dóra, um avinhado; Sebastião, um gallo da serra; Belmira, uma lavadeira; Chico um periquito; Pedro, um colleiro; Virginia, um gaturamo; Alice, uma patativa; Elza, uma maitaca; Alfredo, um chãmchão; $M^{\mathrm{a}}$. Augusta, uma graúna, e eu por ser o dono dos passaros.

\section{EM LEILÃO...}

Estão em leilão as seguintes senhoritas e rapazes residentes no Meyer: Quanto dão pela altura de Alda? pelo sorriso da Dilma? pela bondade de Cremilda? pelos modos da Joanninha? pela tristeza da Lourdes? pela elegancia da Jújú? pela sympathia da Franciscquinha? e quanto dão pela querida leiloeira? 
O Tico-Tico Mundano - T2

(O Tico-tico,Ed. 1480, 14 de fevereiro de 1934, p. 6)

\section{ANNIVERSARIOS}

Festejou a 5 deste mez a passagem de sua data natalicia a graciosa Maria Lucia, filhinha do Dr. Paulo Carvalho e nossa assignante.

Faz annos hoje o menino Arthur Victor, filhinho do Sr. Antonio Pereira Lima presado amiguinho.

Faz annos hoje o mennino Constantino, filho do capitão Lauro de Lima.

Passou hontem a data natalicia da menina Elza, filhinha do nosso collega de imprensa Mauro Loureiro.

\section{EM LEILÃO...}

Leilão dos rapazes e moças do Realengo:

Quanto me dão: pelos labios de Chiquinho? pela delicadeza de Chiquito? pelo formidavel corpo de Chaquibe? pela bondade de Rogerio? pelo sorriso de José? pelos cábellos de Nônô? pelo andar de Maria da Gloria pelas faces de Guilbertina? pelos olhos de Iza pelos pés de Iracema? pelas risadas de Zulma? pelos aborrecimentos de Bijuga? pelo perfil de Luiz M. N.? pela fineza de Honorio? pela aplicação da Selva? Leiloeira Flôr de Amor - Realengo.

Estão em leilão os seguintes jovens de Magé, E. do Rio. Quanto dão: pela "pose" de Eunice M.? pelas risadas da Elisabeth? pelo gracioso andar do Dr. Claudio? pela altura da Nair I.? pelas excursões do Gustavo? pelos modos da Rosita? pelos desgostos do João F.? pelo moreno da Ondina? pelo olhar do Orlando? pela simplicidade da Celia? pelo retraimento de Flavinia? pelas gracinhas do João J.? pelo sorriso da Lubelia? pelas telephonemas do Mello Cunha? E quanto dão pelo linguar da leiloeira?

Estão em leilão as seguintes meninas e meninos do bairro do Rio Comprido: Quanto dão: pela "pose" da Euni - pelos modos de falar da Jacyrema? pela gordura da Lina? pela paciencia do Alvaro? pelos carinhos do Mario? pela belleza do Antonio? pelas pernas do Jorge? pela bondade da Nilza? pelas corridinhas da Lizette? pela educação do Aurelio? pelo sorriso de Delphim? pela côr morena da Rosa? pelo sorriso da Lydia? pela sympathia da Adelaide? pelos cabellos da Yolanda? pela timidez da Ignacia? pela côr dos olhos da Marina? pela esperteza da Linda? pelo nariz da Aurea?

\section{Bébés}


Terezinha, linda filhinha do sr. Hermínio Pinheiro. [legenda da foto de um bebê]

\section{NO CINEMA...}

Querendo organizar um film, contractei senhoritas e rapazes do bairro Olaria: Nair, a linda Rosita Moreno; Isaira, a graciosa Lupe Velez; Myrta, a afamada Norma Shearer; alzira, a sympathica Elissa Landy; Lybia, a meiga Janette Gaynor; Lourdes, a morena Kathe Von Nagy; Aurea, a sedutora Dolores del Rio; M. Antonia, a engraçada Vivian Duncou; Irene, a formidavel Cecilia Parker; Léa, a Rosetta Duncan; Maria Magdalena M., a bontitinha Janette Mac Donald; Aurelio, como George O'Bien; Saul, Tom Tyler; Newton, Ramon Novarro; Jayme C., Charles Farell; Frederico March, Celio M., Ary, José Mogica; Amaro, Adolfo Menjou; Pedrinho, Bem Lyon; Nelson C., Garry; Mario, Raul Roulien; Irany, Ricardo Dix; Oswaldo, Wiliam Haynes.

\section{NO JARDIM...}

Querendo offerecer uma corbeille, ao querido amiguinho José Rios, escolhi as seguintes flores do $4^{\circ}$ anno $\mathrm{B}$, do Grupo Escolar Pedro Varella: Yara, uma vermelha papoula; José Lellis, um simples nyosotis; Lydia, uma graciosa hortencia; Raul, um chrysanthemo; Edith, uma rosa rubra; Ivo, um lyrio; Selma, uma linda bonina; Hilda, uma candida angelica; Nadir, uma palida magnolia Zelia, uma glycinia; Nair, a cesta; Alvaro, a fita, e eu amor perfeito. - Princeza do Paiz das Maravilhas - (Adriana Oliveira).

\section{SECÇÃO DA DOCERIA:}

Querendo offerecer um bolo à distincta e querida professora D.Yolanda C. Pinheiro da Cunha, fiz o bolo com o seguinte: 250 grams. dos cabellos da Wanda, 100 grams. da dentadura do Raphael, 150 grams. da gordura da da Belmira, 100 grams. das ondas da Alayde, 100 gramas das risadas da Zuleide, 200 grams. da linda cabeleira da Etelvina, 250 grams. do cheleirismo de Maria João.

Escove os dentes de manhã, á noite e após as refeições. Escove-os, pelo menos, de manhã, ao meio dia e á noite. 
Walter chaves deMacedo

Mario Camargo

Milton R. Sobrinho

Abiacy Pedrosa de Guttemberg [legendas de cinco fotos de crianças] 
O Tico-Tico Mundano - T3

(O Tico-Tico, Ed. 1484, 14 de março de 1934, p. 6)

\section{NASCIMENTOS...}

Chama-se Luiz o lindo menino, nascido no dia 3 deste mez e filho do casal Dr. Leonardo Pereira - D. Olga Lemos Pereira.

Recebeu o nome de Dulce a linda menina, filhinha do casal Diogenes de Brito - Dila Castro Brito. Dulce nasceu no dia 2 deste mez.

\section{ANIVERSARIOS...}

Faz annos hoje o menino Genaro, filho do sr. Adherbal Nogueira Alves e nosso presado amiguinho.

Maurita, galante filhinha do sr. Mauro Pacheco, viu passar sabado ultimo a data de seu aniversario natalicio.

O nosso amiguinho Jayme Figueiredo festeja hoje a sua data natalicia.

Maria Celia, nossa amiguinha, filhinha do sr. Francisco Veiga, festejou hontem a data de seu natalicio.

\section{VISITAS...}

Esteve em visita à nossa redacção o estudioso Daniel Israel, nosso presado leitor residente em Porto Alegre e ora em excursão nesta Capital.

EM LEILÃO...

Estão em leilão os seguintes jovens de Corumbá - Matto Grosso: Quanto dão: pelos olhos da Elisa Romã? pela dansa do Rodolpho Rocca? pela risada da Sonia Silveira? pelo andar do Nequinho de Barros? pelo desembaraço da Maninha de Barros? pela pose do Jorge Perreira? pela altura do da Celia Vaz? pela sympathia do Virgílio Gondim? pela cabelleira da Dirce Basto? pela elegancia do Clio Proença? pelos cilios da Dora Gomes da Silva? pelo chiquismo do Alexandre Mozziele? pela palestra da Neide Odette Amaral? pela belleza do Mario de Brito? pela dentadura de Cleusa Proença? pela estatura do Nino de Barros? pelas graças da Miracy Soares Peres? pela risada do Cid Wanderley? pela voz da Divina do Couto? pela elegancia do Luiz Fontes? pela intelligencia da Leonarda Esteves de 
Lacerda? pelo sorriso do Clovis Vasquez? pelo louro da Dalila S. Pedro? pela graça do Alcides Marinho? E finalmente, quanto dão pelas leiloeiras do Alheio?

Tendo ocasião de ir numa tarde ao Engenho Novo, resolvi fazer leilão das senhorinhas e rapazes que frequentam assiduamente esta alegre estação.Quanto dão pelo sorriso do Tita? pela honestidade de Paulo? pela altura da Zelinda? pelos lindos cabellos da Iracema? pelo signal da Celia? pela graça do Orlando? pela finura da Irene? pelo bigodinho alinhado do Helio? pela belleza dos cabellos louros da Yvonne? pela elegancia da Maria? pela voz sympathica da Cacilda?

O nosso presado amiguinho Helio Couto, que via passar a sua festa de aniversario a 2 deste mez. [legenda da foto de uma criança montada num cavalo]

\section{SECÇÃO DA DOCERIA...}

Para oferecer um bolo ao Bangu' Foot-Ball Club, escolhi os seguintes ingredientes: 100 grms. do cabello alourado da Eunice Ofrede, 25 grs. dos olhos da Zulma F. Brigger, 50 grs. da dentadura da Iracema Braga, 1/2 kilo da belleza do Walter Curvello, 50 grs. do genio da Gilbertina S. Paulo, uma pitada do sorriso da Marina Garcia, 150 grs. do Ary Pereira, 15 grs. da elegancia do Pedro M. Brasil, 3 grs. do conhecimento de Maria José M. Couto, 75 grs. das palavras doces de Macionilio S. Lima, 10 grs. dos olhos da Rosa Santangelo, 100 grs. da graça da Oracina Cezar, 5 grs. dos modos de Ernestina B. França, 25 grs. dos olhos atrahentes de Leonel Ferreira, 20 grs. dos olhinhos vivos da Iza B. Bruno, 80 grs. das lindas phrases de January G. Nunes, 500 grs. do olhar Walter R. Carvalho, e por fim, pulveriza-se com 3 kilos da sinceridade de Maria da Gloria R. Gomes. Doceira amorosa - Realengo.

Achei a seguinte receita ao passar pelo $5^{\circ}$ anno B, da Escola José Pedro Varella: 250 grs. do cabello da Nylsea, 20 grs. dos oculos da Izabel, 400 grs. da bocca da Lelis, 100 grs. do andar da Liliana. Mistura-se tudo, depois unta-se um pouco da gordura da Maria Lygia, dos olhos da Dyrce, do uniforme da Lourdes. Depois do bolo pronto, enfeita-se com um pouco do falar da Ila, dos sapatos da Ruth, do beiço do Virgilio - Aranha.

\section{NO CINEMA...}

Andava 'Eu" passeiando no Campo de São Christovão, quando deparei com uns rapazes e moças os quaes comparei com os seguintes films: Flavio M. "O rei do phosphoro"; Spineli, 
Diocles e Dioclecio, "Tres mosqueteiros"; Dadá, "O ultimo varão sobre a terra" ； Casimiro, "General York"; Alex, "Dr. R"; Muchacho, "Peso Pesado"; Helio, "Tenente Seductor"; Gilberto Macedo, " O Bem-Amado"; Carlos, "O Promotor Publico"; Amalia, "Mulher Proibida"; Carmen Fonseca, "Mulher Indomavel"; Yvone, "Noiva do Céo"; Eunice, "Loura e Seductora"; Nathalia, "Mulher notoria"; Zuleika, "Carne e o Diabo"; Haydéc Assumpção, "Uma Alma Livre. ; Carmen, Denair e Nicia, "3 Garotras Ludinas"; Ruth "Cavadoura de Ouro"; Osíris Nascimento, "Madame Satan". C. F. - São Christovão - Rio.

Querendo organizar um film escolhi os seguintes artistas: Lygia, a encantadora Norma Shearer; Zelia, a elegante Jean Harlow; Odayr, o meu encantador George O'Brien; Moacyr, o tenor José Mojica; Lara, a morena Lupe Velez. Eu, a princeza do paiz das maravilhas. 
O Tico-Tico Mundano - T4

(O Tico-tico,Ed. 1487, 4 de abril de 1934, p. 4)

\section{NASCIMENTOS...}

Nasceu o menino Paulo, filhinho do casal Diogenes de Paula Bittencourt - D. Odette Salles Bittencourt.

Está em festas o lar do sr. Antenor Figueira e de sua esposa. D. Consuelo Figueira, por motivo do nascimento de sua filhinha Edelwein.

\section{ANNIVERSARIOS...}

Faz annos hoje o menino Mauro Santos, nosso presado assinante e amiguinho.

Completou seis annos sabado ultimo a graciosa Sarah, filhinha do Dr. Antonio de Queiroz.

Festejou hontem a passagem de sua data natalicia a nossa amiguinha e leitora Geny Santos.

O Sylvio, o galante filhinho do sr. Oswaldo Pinheiro, festeja hoje a data de seu anniversario natalicio.

\section{NO CINEMA...}

Estando eu em passeio por Bento Ribeirão vi os seguintes rapazes e moças nos quaes reparei os seguintes films:

Abílio, "O ultimo varão sobre a terra"; Esther "Mulher Indomavel"; Constantino, "Uma noite no cairo"; Djalma, "Cavalleiro da Noite"; Alvarino, "Voando para o Rio"; Ereila, "Fiel ao seu amor"; Alice, "Cavadora de ouro"; Luiz, "Ama-me esta noite"; Juvenal "Assobiando no escuro"; Dolores, "Mulher só aquella"; Georgina, "Anjo e demonio", Eduaro, "Rei dos ciganos"; Alexy, "Noiva do céu"; Aracy, "A' procura de um amor"; Aurora, "Casamento liberal"; Odoripio, "Beijo para todas"; Francisco, "O bem amado".

\section{SECÇÃO DA DOCERIA...}

Querendo offerecer um bolo á nossa sempre amiguinha Ercilia ahi vae a receita:

100 grms. da belleza de Aracy, 250 grms. dos olhos de Eduardo, 150 grms. das graças de Abilio, 200 grms. do cabello de Luiz M., 600 grms. do sorriso de Odoripio, 50 grms. do andar ligeiro de Mario, 300 grms. da gordura de Alexy, 200 grms. do rosto de Constantino, 
400 grms. das sobrancelhas de Aurora, 350 grms. do genio de Juvenal, uma pitada da ideia de Luiz, 1/2 kilo das valentias de Djalma, 350 grms. dos labios de Georgina.

\section{EM LEILÃO...}

Estão em leilão os seguintes rapazes e moças de Bento Ribeiro: Quanto dão: pelo sorriso do Abilio? pelos dentes de Odoripio? pelos cabellos da Regina? pelas graças de Manoel? pelo vestido branco de Aracy? pelos olhos de Alex? pela calma de Herculano? pelo tamanho de Alexy? pelo porte de Juvenal? pela prosa do Constantino? E finalmente quanto dão pela querida leiloeira?

Estão em leilão os seguintes alumnos do Lyceu de Artes e Officios - $1^{\circ}$ anno Perito Contador:

Quanto dão: pela linda dentadura e polidez do João Baotista de Menezes? pelos bigodinhos do Mario A Mello pela mantinha preta e vermelha do Arnaldo de Oliveira (Leleco)? pela valentia do Antonio Ferreira pela bondade do José Nogueira pelos cabellos louros do José Castro Neves? $2^{\circ}$ anno Propedeutico: pela elegancia do Paulo Lacerda? pela gordura do Mauricio Simontob? pela boquinha do Eneo Menezes? pelos delicados pézinhos do Eduardo Raymundo? pela fardinha do José Luiz? pelo meio kilo do Edmundo Castro Novo?. $1^{\mathrm{o}}$ anno Propedeutico: - Quanto dão pelo quixinho do Arthur Branco? pelos dentes do Luiz Ross? pelos oculos do Domingos Ouro Fino? pela carinha do Jacy Moura? pelo corpo de athleta do Alfredo Santos? pelas delicadas mãos do Affonso Pinto Carneiro Junior? Admissão: - Quanto dão pela belleza do Almir Barroso? pela sympathia do Sergio Savreda Cardoso? pela graça do Roberto Peres. pela robustez do Amador Peres? pela santidade do Armando Von Borell Negreiros? E pela minha lingua de leiloeira? - (Paulista).

\section{NA BERLINDA...}

Estão na berlinda as seguintes meninas e meninos do $5^{\circ}$ anno B da Escola do Cruzeiro: Helena S. L., por ser bem educada; José Luiz C., por ser camarada; Maria de Lourdes S., por falar como nortista; Wilson, por ser colado; Beatriz, por ser a mais adeantada da classe;Maria S. F., por gostar muito... muito... da Déa M., Dulce N., por ser "do outro mundo"; Margarida D., por ser graciosa; José F. B., por ser intelligente e engraçado; Maria M., por andar sem meias; Graciano R., por ser querido; Déa M., por ter lindos olhos; Adal, por ser a mais camarada da classe; Leda A., por se parecer com a Greta Garbo; Leda E., por ser bonitinha; Yolanda M., por ser sympathica; Hugo M., por ser estudioso, e eu, por estar dizendo tudo isso em publico. - Arsene Lupin. 


\section{NOSSOS AMIGUINHOS}

José Caetano, filho do Sr. José Alcides Moraes

Nossa amiguinha Yara Cunha

Nosso leitor Ugolino Cordeiro de Abreu

Nosso amiguinhoo inteligente Cesar de Nascimento [legenda de 5 fotos de crianças] 


\section{O Tico-Tico Mundano - T 5}

(O Tico-tico,Ed. 1434, 9 de maio de 1934, p. 6)

\section{NASCIMENTOS...}

Com o nascimento do menino Ingacio, acha-se em festa o lar do Ignacio de Carvalho e de sua exma. esposa, sra. d. Davina Jardim de Carvalho, residentes em Belo Horizonte.

Acha-se enriquecido, com o nascimento de um menino, que receberá o nome de Affonso, o lar do sr. Affonso Vaz de Mello Carvalho, e de sua exma. esposa sra. d. Estella, residentes em Bello Horizinte.

Nasceram na capital de São Paulo : - Lucia Thereza, filha do sr. José Adail de Mattos, funcionario do Palacio da Justiça, e de d. Benedita de Oliveira Mattos. - Neyde, filha do sr. Francisco Nicolaci, funcionario da Repartição de Aguas e de Maria Nicolaci. - Alcides, filho do sr. José Pinto de Oliveira, auxiliar da firma J. Martins \& Cia., e de d. Olga de Oliveira. Olympio, filho do sr. Sylvio Marcondes e de d. Zulmira Marcondes.

Desde o dia 13 do mez ultimo que está em festa o lar do sr. Pedro Salomão, residente em Laguna, e de sua exma. esposa d. Waldira Soares Salomão, pelo nascimento e seu filhinho Zanir.

\section{ANNIVERSARIOS}

Faz annos hoje o menino Armando, filhinho do Dr. Sylvio Pacheco.

Passou sabado ultimo a data natalicia da graciosa Marcella, filhinha do sr. Estevão da Costa Pinto.

Completou hontem oito annos o estudioso Moacyr, filhinho do sr. Antenor Pinheiro.

A nossa graciosa amiguinha Margarida, filhinha do casal sr. Alvaro Guimaraes - D. Odette Lima Guimarães, festejou ante-hontem a passagem de seu anniversario natalicio.

\section{EM LEILÃO...}

Estão em leilão os seguintes rapazes e moças que frequentam o bairro do Riachuelo: Quanto dão pela gordura do Ary? pelo signalzinho do Francisco? pelas risadas de Alberto? pelos discursos do Roberto? pelo comportamento do Alexandre? pela pose do Durval? pela belleza do Morgado? pelos olhos de Mariazinha? pela graça da Yvonne? pela pose da Jacyra? pelo andar do Enio? pelo falar do Armando? pela estatura do Cyro? pelo rosto do Aydil? pelos vestidos de Myone? pela barralinha alinhada do Edilson? pelo sorriso do Osmar? pelo porte de Delarey? pela elegancia do Dyrwal? pela bondade da Hilda? pelo bigodinho do 
caetano? pela altura da Narciza? pela formosura do Aragão? E quanto dão pela lingua da leiloeira?

Princeza levada

Estão em leilão as seguintes meninas e meninos da rua Barão de São Felix: Quanto dão pela voz de Russo? pelo andar de Yolanda? pela belleza de Augusto? pelo dente de ouro de Nathalia? pelos olhos de Paco? pelo sorriso de Ephigenia? pelas poesias de José? pelos cabellos de Nininha? pela pose de João? pelo corpo de Luiz Quirina? pelo brincalhão de Juca? pelas cantigas de Elza? pela bondade de Edgar? pelos trabalhos de Rosa? pela bocca de Elpidio? pela bondade de Izaura? pela gordura de Affonso? pelas rodas de Benita? pelos olhos ternos de Maluco? E pela minha lingua quanto dão?

B. S. P. R.

Escove os dentes de manhã, á noite e após as refeições.

Escove-os, pelo menos, de manhã, ao meio dia e á noite.

Estão em leilão as moças e rapazes do bairro de Grajahu': Quanto dão pela cor morena do Arthur? pelo sorriso da Carmita? pelos cabellos de Julinha? pelos olhos de Céomar? pela elegancia de Carlitos? pela falta de Pedro? pelo sorriso de Elza? pelos vestidos de Risolete? pela seriedade de Fernando? pelo modo de Geraldo? pela altura da Eliza? pelo modo de andar de Celina? pelo estudioso Nilo? E quanto dão pelo leiloeiro?

M. A.

NA BERLINDA...

Estão na berlinda os seguintes meninos e meninas da rua Lygia (Olaria): Rubens por ser muito delicado; Nilsa, por ser muito querida; Dinah, por ser elegante; Aluysio, por ser bonito; Eunice, por ser engraçada; Altilas por ser estimado; Juracy, por ser elegante; Jorge, por ser bomzinho; Léa, por ser gorda; Lygia, por ser retraida; Eidas, por ser estudioso; Elza, por ser delicada; Ondina, por usar vestido curto; Alzira, por ter votação para rainha de 1934; Zulmira por ser amavel; Leny, por ser loura; E eu, por ser a mais engraçadinha da turma.

A. B. C. 
Laris, filho do Prof. Joaquim Gonçalves Pereira Filho.

Alvaro Rosas

Aureo Vieira

Walter Veado

Therezinha de Jesus Gonçalves [legendas de 5 fotos de jovens e crianças] 
O Tico-Tico Mundano - T6

(O Tico-tico,Ed. 1496, 6 de junho de 1934, p. 6)

\section{NASCIMENTOS}

O sr. Achiles Crivelado Salvador e sua exma. esposa estão de parabens com o nascimento de sua filha Véra Terezinha.

O sr. Herminio Fernandes, e sua exma. esposa estão com o lar em festas pelo motivo do nascimento de sua filha Norma.

Está em festas o lar do sr. Olavo M. Oliveira e sua exma. esposa d. Edelmira B. Oliveira, pelo nascimento de sua primogenita, que recebeu o nome de Arjorie Maria.

O sr. João Carminatti e sua exma. esposa têm o lar em festas com o nascimento de seu primogenito Newton Porbem.

\section{ANNIVERSARIOS}

Faz annos hoje o menino Quintino Neves, nosso leitor, residente em Belo Horizonte.

Passou domingo ultimo data natalicia da graciosa Eulina, filhinha do Dr. Eugenio Costa

Completou hontem oito primavéras a gentil Carmem, filhinha do sr. Antonio Pereira Costa

Oscar Veiga, nosso estudioso amiguinho, vê passar hoje a data de seu anniversario natalicio.

\section{EM LEILÃO...}

Estão em leilão os alunos e alunas da Escola N. S. das Dôres: Quanto me dão: pelos vestidos curtos de Neli? pelos dentes de Gildinha? pela beleza de Elena? pela bondade de Adalgiza? pela gordura de Wanda? pela beleza de Maria Celeste? pelo moreno de Tomaz? pela peraltice de Gustavo? pelos modos de João Baptista? pela elegancia? de Vasco? pelos desenhos de Laurinha? pelo comportamento de Julio?

Estão em leilão os rapazes e moças do "Colégio Independencia". Quanto dão: pelo espelho da Candida? pelo sorriso da Zeni? pelas risadas da Elisa? pelagordura da Lourdes? pelas respostas da Celina? pela saia da Gloria? pela estudiosa Yára? pela delicadeza do Fernando? pela beleza da Alexandrina? pela vitrola da Eunice? pelos olhos conquistadores do Nunan? pelos dentes do Erminio? pelas unhas do Alfredo? pela bondade do Sá? pelas palhaçadas do Cèa? pelo bigodinho do Dal? e quanto dão pela minha lingua? 
Escove os dentes de manhã, á noite e após as refeições. Escove-os, pelo menos, de manhã, ao meio dia e á noite.

Estão em leilão as moças e rapazes do Grajaú.

Quanto dão: pela pose de Elza? pelos olhos da Carmita? pelo sorriso da Ceomar? pelo apelido do Pedro? pelos cabelos do Derval? pelas risadas do Grijalva? pelas sobrancelhas do Julinho? pelo comportamento do Geraldo F.? pela elegancia da Clara? pela pose do Carlito? pela bondade da Maria Candida? pela graça do Geraldo Araujo? pela pele da Judith? pela delicadeza do Mario? pelas cantigas da Risoleta? pelos discursos de Nilo? pelos trabalhos de Niobel? pelo andar do fernando pela boca da Olguinha? pelos oculos do Olgmar? pelos gestos da Marilda? E quanto dão pela lingua do leiloeiro? - Principe Encantado.

Estão em leilão os seguinte alunos da Ecola Gonçalves Dias, do $3^{0}$ anno 22: Quanto dão pela tagarelice da Leda Enes? pelos cabelos da Edenir? pelo sorriso da Neide? pelos gestos da Nirce? pela gordura da Silvia? pelos olhos olhos da Láis? pelo tamanho da Conceição? pelo azul dos olhos da Marilena? pela quietude do Luiz? pelas travessuras do Artur? pela pose da Alcione? pela sabedoria da Yeda? pela tristeza da May? pelas palhaçadas do Orlando? pelas conversas da Alzira? pela voz da Maria Alda?

Estão em leilão as seguintes meninas e meninos, da escola experimental Manoel Bomfim:

Quanto dão: pelos lindos olhos de $\mathrm{M}^{\mathrm{a}}$ Helena C.? pelos cachinhos de $\mathrm{M}^{\mathrm{a}}$ Augusta? pelos claros dentes de Luci? pela graça de Rodolfo? pela boquinha de M. Lauro? pelo sorriso de Anice? pela elegancia de Ires S.? pela tagarelice de Alberto? pela bondade de Sibele? e eu quanto dão para eu, organizadora do leilão?

Leilão em Botafogo. Quanto dão: pelos sorrisos da Ana? pelos olhos de Irene? pela pasta de Maria? pela boina de Olga? pela linda voz de Evaristo? pela cisma de Wento? pela graça de Josefina? pelos vestidinhos de Izaura? pela alegria de Véra? pelo andar de Almeirinda? pelo geitinho de Maria? pela prosa de Crizalida? pelo sorriso de Heliete?

\section{OS CONDUTORES DO BRASIL DE AMANHÃ}

Nosso amiguinho Jair, no dia de sua $1^{a}$ comunhão - (Baia)

Octavio, filho do Dr. Octavio de Araujo Novaes - São Paulo

Eny e Ney, filhos do sr. Adalberto Menezes - São Paulo

Nosso Amiguinho Gildasio A. Sant'Anna [legendas de 4 fotos de crianças]. 
O Tico-Tico Mundano - T7

(O Tico-tico,Ed. 1500, 4 de julho de 1934, p. 6)

\section{ANIVERSARIOS}

Passou a 18 do mês findo a data natalicia da interessante menina Haydèe Freire de Souza,filha do sr. Anchyses Bettenmuller de Souza e D. Ruth Freire de Souza.

Faz anos hoje o estudioso Arnaldo Vieira de Nobrega, nosso assinante residente em Juiz de Fóra.

Mariazinha Gumarães, nossa prendada amiguinha, festejou ante-hontem a passagem de seu aniversario natalicio.

A 30 do mês findo completou dez anos o nosso leitor Murilo Nascimento.

Fez anos hóntem a menina Laura, filhinha do Dr. Luiz Bastos.

\section{NOS ARES...}

Partiu da praia de Copacabana o avião "9 de fevereiro". Ia repleto. Tinha como aviador Romario, como mecanico Helio, e eram passageiros os meninos e meninas que segue: Renato,

Lucy, Carlos, Sylvia,Carmelio, Juliana, Cal, Marina e Eraldo. No caminho encontramos os seguintes meteóros: A garôa que era Elza, o vento que era o Walter, a tempestade era Haydée e o trovão que era o José Armando. Prosseguimos a viagem sendo encontrados ainda a Lua que era Rachel, o orvalho que era o Paulo, a noite era Yole. Continuamos a viagem em linha reta e visitamos as três Marias que eram: $\mathrm{M}^{\mathrm{a}}$ Helena, $\mathrm{M}^{\mathrm{a}}$ Lourdes e $\mathrm{M}^{\mathrm{a}}$ Thereza, o Sol que era Gildo, Venus que era Véra, a Estrela Dalva era Yvone. A seguir encontramos o Dia, era este o Zezé. Finalmente, chegamos ao logar de onde partira o avião "9 de fevereiro" e onde fomos bem recebidos. Estrela Pasageira.

\section{EM VIAGEM...}

O avião "Meteóro" saiu de S. Critóvão rumo a Hollywood. Era aviador Zézinho e o mecanico José. Passageiros: Véra, Carlos, Elvira e Ruth. Durante o Percurso de viagem fomos surpreendidos pelos seguintes meteóros: Celia, a garôa; Claudio, o vento; Marilia, a tempestade; Olavo, o relampago. Indo em seguida aterrissar em Hollywood onde vários astros cinematográficos já esperavam ansiosos. 
Durante a viagem no "Cap. Areona" encontramos os seguintes meteóros: José, o orvalho; Elvira, a neblina; Carlos, o relampago;Zézinho, o trovão; Nany, a geada; Claudio, o calor; Celia, a noite; Olavo, o vento; Marilia, a tempestade; Véra a garôa. E, eu,J. F. C., O DIA.

\section{EM LEILÃO...}

Estão em leilão os alunos do Externato Santo Antonio Maria Zacaria. Quanto dão: pela cabeça raspada de Antonio Valentim? pela franginha do Mario? pela graça do Antonio Monteiro? pelo andar do José Carlos pelas brincadeiras do Joaquim? pela força do Léo? pelos botões da farda do Anibal? pela altura do Nelson? pelas risadas do Tiocles? pelas graças do Ary? pelo comportamento do Paulo? pelas graças do Marcelo?

Escove os dentes de manhã, á noite e após as refeições. Escove-os, pelo menos, de manhã, ao meio dia e á noite.

Estão em leilão os seguintes meninos da rua Benjamin Constan: Quanto dão pelos gestos de menina do Aranha? pela graça da Ilda? pelos cabellos lisos da Estela? pela valentia da Jacira? pelos olhos castanhos da Ilda pelas peripécias do Marcolino pela bicicleta do Marcolino pela beleza do Preguinho pelas graças do Levi? pelos passeios de Tedy? pelas shooteiras do Anibal?

Estão em leilão as seguintes moçase rapazes da Remeteção Nova America: Quanto dão: pelo sorriso da Elza T.? Pela elegancia da Ida T.? pelo bigodinho do Betinho? pelas costelètas do Aleixo? pelo bonet do Arsenio? pelos cabelos da Brigida? pela boca da Ida? pela ligeireza do Mineiro? pela bondade do Caetano? pelo sorriso da Zizinha? pelos olhos da Elodia com Euclides? pela bondade do Luiz? pela gentileza do Manivela? e quanto dão pela inteligencia da leiloeira?

Leilão moças de e rapazes do Meyer. Quanto dão: pelo andar de Zezé? pela gentileza de Djanira? pela graça de Julia? pelo comportamento de Jandira? pela delicadeza de Dalva? pelo dente de ouro de Dolores? pelos lindos dentes de Maria? pelos cabellos de Anita? pelos sorrisos de Lêda? pelosolhos de Luzia? pelas meias curtas de Zuleika? pela pose da Lu-Juca? pelas risadas do Helio? pela graça do Americo? pelo andar de Mylsom pela elegancia do Gauracy? pela voz do Dylo. 


\section{NOSSOS QUERIDOS AMIGUINHOS}

Riva, filhinha do Sr. Henrique Rosa Tuschler.

Maria de Lourdes, filhinha do Major Sabido.

Nossos amiguinhos Helio, Rubens, Maria, Zilda e Dirce.

Nosso leitor Atrogildo Lima. [legendas de 4 fotos de crianças.] 
O Tico-Tico Mundano - T8

(O Tico-tico,Ed. 1504, 1 de agosto de 1934, p. 6)

\section{OS AMIGUINHOS D'O TICO-TICO}

Adriana Padilha Oliveira

Jacyrema Rodrigues

Ary, filho do Sr. José Maria Vasconcellos - da Baixada Ultramarina desta capital.

Waldyr, Jacyr e Elder filhos do Sr. Egydio Nascimento.

José Carlos filhinhos do Dr. Claudio Vianna.

Marilia Carmem, filhinha do Dr.Cleantho de Albuquerque

Irlanda, filha de Vicente Ragone,Minas. [legendas de 7 fotos de crianças]

\section{NACIMENTOS}

Acha-se em festas desde sábado ultimo o lar do Dr. Abelardo Carvalho de Oliveira e de sua esposa D. Semiramis de Oliveira, por motivo do nacimento de sua filhinha Célia.

Naceu o menino Nelson, filhinho do casal Dr. Homero de Aguiar - D. Olivia Menezes de Aguiar.

Chama-se Pedro Luiz o lindo menino que, desde o dia 24 do mês ultimo enche de sorrisos e venturas o lar do sr. Custodio Guimarães e se sua esposa D. Carlota Pimenta Guimarães.

Leny é o nome da linda primogenita do nosso presado colaborador Pedro de Freitas Cunha e de sua exma. senhora D. Elza de Castilhos Cunha. Leny, a que auguramos um risonho futuro, nasceu no dia 27 de Maio ultimo.

\section{ANIVERSARIOS}

Faz anos hoje a menina Edith, filhinha do Sr. André Montenil.

Passou sábado ultimo a data natalicia do nosso estudioso amiguinho Oscar Boaventura Guimarães, residente em São Paulo.

Passou sábado ultimo a data natalicia do nosso amiguinho e leitor Eduardo de Cardoso de Mello completou hontem oito anos de idade.

Passou hontem a data natalicia da graciosa Dulce,filhinha do Dr. Olavo Pereira Leite.

Viu passar sexta-feira ultima a sua data natalicia a graciosa Marina, filhinha do Sr. Estevão Correia. 


\section{EM LEILÃO...}

Estão em leilão as seguintes meninas da $1^{\mathrm{o}}$ série $\mathrm{n}^{\mathrm{0}} 2$, do $\mathrm{I}$. LaFayette. Quanto dão: pelo tipo Primo Carnera da Thais? pela tristeza da Aurea? pela grande aplicação da Elita? pelo sorriso da Dulce B.? pelos modos infantis da Dulce T? pela amizade que a Alba tem á poesia? pela altura da Hilda? pela amizade da Norma com a Edeloria? pela amizade que Elza, Yeda e Zaira tem á D. Mayar? pela alegria da Daluza? pelo acanhamento da Gilda? pelo sorriso constante da Marina V.? pelo andar da Laurina D.? pelo olhar da Bertha A.? pelo tipo claro da Bertha B.? pelo tipo "mignon" da Geysa?

Escove os dentes de manhã, á noite e após as refeições. Escove-os, pelo menos, de manhã, ao meio dia e á noite.

Estão em leilão os alunos e alunas do $4^{\circ}$ ano do Grupo Escolar do Piaui. Quanto me dão pelos cabelos de Marina Castro? pelo adiantamento de Isaura? pelos desenhos de Celio? pela gordura de Luiza? pelo capricho de Laurinha? pela delicadeza de Sebastião Carvalho? pela bondade de Nativa? pelos dentes de Marina? pela voz de Dulce? pela graça de Edgar? pelo comportamento de Maria José? pelas travessuras de Carmosina? pela simpatia de Ninita? pelo moreno de Antonio Fonseca? pela moleza de Ilda? pela esperteza de Aparecida? pelo andar de Evangelina? e quanto dão por mim, organizadora do leilão?

\section{SECÇÃO DA DOCERIA...}

Querendo oferecer um bolo aos moradores de Tanguá, escolhi os seguintesingredientes: 200 grs. do sorriso do Reynaldo, 150 grs. do tamanho do Geraldo, 150 grs. do acanhamento do Antonio, 100 grs. do sorriso do Norival, 75 grs. do andar do Oldemar, 175 grs. da inteligencia do Anísio, 100 grs. da beleza do Luiz, 150 grs. da simpatia do Amavel, 700 grs. da pose do Lauro, 100 grs. da indiferença do Mimi. Bate-se com a sinceridade do Lafayette e leva-se ao forno com a bondade do Braga.

Doceira Misteriora

NOSSOS AMIGUINHOS

Hugolino Correia de Abreu - Santos

Therezinha, Bastinho, Francisquinhoe Antonico 
Mario, filho do casal Alencar Pereira Leite - Minas.

Nerecy Rodrigués Machado

José Mauricio e Antonio Ribeiro Penna - Bello Horizonte. [legendas de 5 fotos de crianças] 
O Tico-Tico Mundano - T9

(O Tico-tico,Ed. 1524, 19 de dezembro de 1934, p. 6)

\section{NASCIMENTOS}

Nasceu a 7 deste mez a linda Carmen, filhinha do casal sr. Antenor Carvalho de Oliveira e de D. Carmen Salles de Oliveira.

Chama-se Ruy o robusto primogenito do casal Lauro Figueiredo - D. Emilia Castro Figueiredo.

\section{ANNIVERSARIOS}

Faz annos hoje o menino Ary, filhinho do sr. Oscar Veiga.

Completou seis annos no dia 10 deste mez a graciosa Lucy, filhinha do Dr. Renato Jorge.

Mario Luiz, galante filhinho do capitão Jayme Pinheiro, festejou hontem a data de seu anniversario natalicio.

O menino Antonio Monteiro Baião, que fez annos em 29 de Novembro e é um dos nossos queridos leitores. [legenda da foto de uma criança]

\section{NO CINEMA...}

Querendo organizar um film que será intitulada "Idade de Mulher", com varios alumnos do $5^{\circ}$ anno $\mathrm{B}$ da Escola 7, fiz a seguinte distribuição: Zenaide, a moreninha Kathe von Nagy; Ruth, a blonde Jean Harlow; M. Magdalena, a deusa Greta Garbo; Antonio, o comico Harold Lloyd; Wanda I., a sentimental Mirna Loy; M. Amelia G., a infantil Janet Gaynor; Celina, a irrequieta Conchita Montenegro; Waldyr, o irresistivel Clark Glabe; Olinda, a encantadora Joan Crawford; America, a colossal Kay Francis; Armanda, a fantastica Frances Drake; Hugo, o romantico Ramon Novarro; Amneris, a pyramidal Norma Shearer; M. de Lourdes B., a Madge Evans; Octalícia, a indifferente Adrienne Ames; Osorio, o patricio Raul Roulien; Palmyra, a Katharine Hepburn; Dora, a levada Dorothy Jordan; Léa Assis, a inegualavel Dolores Del Rio; José M., o interpido Jim Mc Coy. Eu... a incrivel diretora improvisada. 
ForaM contractados para fazer um film "Amôr", alguns alumnos do G. M. de B. Mansa: Cléa, a encantadora Conchita Montenegro; Celso, o nosso patricio Raul Roulien; Clia, a fascinante Norma Shearer; N. Soares, o encantador Robert Montgomery; Helena, a deslumbrante Kay Francis; Almeida, o seu incomparavel galã Georde O Brien; Aracy, a meiga Janet Gaymor; Wilson S., o sympathico Charles Farell;Colette, a pequena Shirley Temple; Ismael, o lindo Lionel Barrymore; Myriam, a Jaon Crawford; L. Godinho, Johan Barrymore; $\mathrm{M}^{\mathrm{a}}$. Gloria, a gosada ZaSú Pitts; Daryo, o John Bolles; Édmes, a quieta Evelym Venahle; José Camargo, o irresistivel Clark Gable; $\mathrm{M}^{\mathrm{a}}$. Apparecida, a amorosa Myrna Loy; Alvaro, o pensativoWilliam Farell; Carmelia, a inesquecivel Elissa Landi; Cicero Bittencourt, o querido Frederich March; Córa, a risonha Collen Moore; Lair, o gosado Maurice Chevalier, e de Adelaide, a formidavel Janette Mac Donald. E eu, a loura Jean Harlow.

Escove os dentes de manhã, á noite e após as refeições. Escove-os, pelo menos, de manhã, ao meio dia e á noite.

NÃO DEIXEM DE COMPRAR!
a edição extra-ordinaria d'O TICO-TICO, já á venda,
dedicada ao
Camondongo Mickey
O Camondongo Mickey, o famoso e querido
Ratinho Curioso que figura em todos os numeros d'O
TICO-TICO, está em magnificas aventuras, ilustradas a
côres, constituindo uma edição extraordinaria d'O
TICO-TICO, já á venda, ao preço de 1\$500.
A edicão extraordinaria d'O TICO-TICO dedicada ao

EM LEILÃO...

Estão em leilão as moças e rapazes da Rua Uruguay: Quanto dão: pelos machos do vestido da Odette? pelos modos da Thereza? pelo andar da Ida? pelos dentes da Neusa? pelo sorriso da Léa? pela graça da Kimié? pelos cabellos da Yalda? pelo penteado da Augustinha? pela elegancia do Alberto? pela gordura do Danilo? pelo signal da Satie? pela delicadesa da Midoria? pela altura da Lourdes? pelo salto alto da Dulce? pelo 
bigode do Jorge? pela innocencia da Marilda? pelas risadas da Nina? pela pose do Heitor? pelo repartido da Véra? pelo sorriso da Magdalena? pelo vestido rosa da Joanna? pelo olhar da Ruth? pelas relações do Evaristo? pelos olhos do Antonio? pelas sobrancelas da Iza? pelas gaiatices do Waldemar? e quanto dão pela lingua do leiloeiro?

\section{SECÇÃO DA DOCERIA...}

Querendo fazer um bolo para ser offerecido á professora D. Palmyra, da Escola Epitacio Pessoa, tirei os seguintes ingredientes do $4^{\circ}$ anno B-V-3: 500grs. da gentileza da Marihia, 200 grs. da graça do Arthur, 300 grs. da prosa do Euclydes, 90 grs. das travessuras do Agostinho, 100 grs. das brigas do Avelino, 90 grs. da fala do Ezequiel, 290 grs. dos olhos de Licio, 100 grs. do beiço do Benigno, 500 grs. do nariz do Djalma, 700 grs. do sorriso de Euvira, 100 grs. das piadas do Gastão, 500 grs. dos cabellos do Nilzon, 100 grs. da voz do Antonio, e meia colher de chá de minha lingua ferina.

B. R. S.NO JARDIM..

Querendo em nome das alumnas do $5^{\circ}$ anno B da Escola "Chile", offerecer uma corbeille de flores á nossa professora D. Adelir Albuquerquer, escolhi as seguintes do meu jardim: Marília, um lindo amor-perfeito; Guilhermina, uma bocca de leão; Ilda, uma delicada acucena; Eneide, uma rosa; Maria Eleonora, uma mimosa violeta; Regina, uma magnolia; Maria Julia, um pequenino myositis; Zoreth, uma camelia; Lygia, uma linda margarida; Ninsa S., uma cravina; Lucia, uma afamada Victoria Régia; Olinda um chrysanthemo; Valda, uma hortencia; e eu o cartão de visitas que leva os seguintes dizeres: Dedicada mestra, D. Adelir. 
O Tico-Tico Mundano - T10

(O Tico-tico,Ed. 1532, 13 de fevereiro de 1935, p. 6)

\section{NO JARDIM...}

Querendo offerecer uma cesta de flores ao nosso querido colega Nelson, escolhi num jardim as seguintes flores: Helio, um lyrio; Celio, um bogary, Alzira, uma rosa chá; Adelaide, uma violeta; Ecias, um amor-perfeito; Conceição, um copo de leite; uma orchidéa; Ruy, um copo de leite; Lygia, uma camelia; Renê, um cravo; Waldemar, um botão de ouro; Rudes, uma dhalia; Nilton, um chrysanthemo; Francisco, um jasmin; Neuza, uma rosa; Edna, uma papoula; Neuza P., uma Jacinta; Valerio, uma bocca de leão; Jorge, um myosotis; Dorothy, uma tulipa; Cely, uma cravina; Odette, uma bonina, Luiza a cesta e Otto o laço de fita. A cesta será entregue ao collega por sua admiradora.

\section{NO CINEMA...}

Querendo organizar um film escolhi os seguintes meninos e meninas de Bento Ribeiro como artistas: Alzira, a seductora Joan Crawford; Nelson, o nosso querido compatriota Raul Roulien; Adelaide, a sympathica Claudette Golbert; Nilton, o irresistivel Clark Gable; Joffre, o antipathico Adolphe Menjou; Rudes, a maravilhosa Lupe Velez; Conceição, a amorenada Rosita Moreno; Neuza, a ingenua Janet Gaynor; Carmen, a travessa Jean Harlow; Valerio, o amoroso Mauricio Chevalier; Francisco, o celebre José Mojica; Rui, o destemido Tom Mix; Celio, o adorado Ramon Novarro; Ecias, o incomparavel Charles Farrell; Neuza P., a querida Sylvia Sydney; Lygia, a deliciosa Lyliam Harlow; Helio o Tom Tuler. E eu, a amorosa Marlene

Dietrich.

\section{Artista mysteriosa}

\section{EM LEILÃO...}

Leilão dos alumnos do Curso de Admissão do Collegio "Sylvio Leite". Quanto dão: pela beleza sem par da Lourdes Castanheda? pelos olhos da Sylvia Leite? pelo perfil do José? pela "modestia" da Sylvia Moreira? pelos olhos da lourdes E. Branco? pelas gracinhas do Roberto? pela graça do Placido? pela meiguice da Else? pelo narizinho da Cybele? pela calma do Camillo pelos cachinhos da Yedda? pelos dentes da Lourdes Monteiro? pela "gordura" da Licy? pelo "pouco falar" da Dina? pelo comportamento Yara? 
pela altura do Nelson? pelas sobrancelhas do Armando? E, terminando, quanto dão pela mascote da turma a Gatinha Nervosa?

\section{Uma linda fantazia para o Carnaval}

O numero de Fevereiro do belo figurino Moda e Bordado publica, como um verdadeiro presente ás creanças, o molde de um lindo kimono chinez, que constitui interessante phantasia para o Carnaval.

Para confecção do bellisimo kimono são precisos 1,m20 de tecido para o paletot

e 1,m60 para a calça em fazenda de 0,m80 centimetros de largura.

O molde pode-se augmentar ou diminuir quanto fôr precizo.

- Para tirar o molde, colloca se uma folha de papel fino por cima do desenho e copia se cada parte do mesmo separado. Como de costume collocam-se as diversas partes na fazenda - fio direito - e marca-se esta em volta do molde com alinhavo. Augmenta-se na fazendo para as costuras e arma-se na marcação.

-Adquiram, pois o numero de Fevereiro de Moda e Bordado.

O Senhor dará um magnífico presente ao seu filhinho, comprando o bello livro "Meu Livro de historias", A' venda em todas as livrarias.

Escove os dentes não sómente nas face externa, o lado do sorriso... Escove-os em todos os sentidos e direcções, porque não é sómente contra a face externa que actuam as fermentações da 